\title{
Peatlands and Histosols in Canaan Valley National Wildlife Refuge, West Virginia
}

\author{
Mitzy Leigh Schaney \\ mschramk@mix.wvu.edu
}

Follow this and additional works at: https://researchrepository.wvu.edu/etd

Part of the Geomorphology Commons, and the Soil Science Commons

\section{Recommended Citation}

Schaney, Mitzy Leigh, "Peatlands and Histosols in Canaan Valley National Wildlife Refuge, West Virginia" (2019). Graduate Theses, Dissertations, and Problem Reports. 7486.

https://researchrepository.wvu.edu/etd/7486

This Dissertation is protected by copyright and/or related rights. It has been brought to you by the The Research Repository @ WVU with permission from the rights-holder(s). You are free to use this Dissertation in any way that is permitted by the copyright and related rights legislation that applies to your use. For other uses you must obtain permission from the rights-holder(s) directly, unless additional rights are indicated by a Creative Commons license in the record and/ or on the work itself. This Dissertation has been accepted for inclusion in WVU Graduate Theses, Dissertations, and Problem Reports collection by an authorized administrator of The Research Repository @ WVU.

For more information, please contact researchrepository@mail.wvu.edu. 


\title{
Peatlands and Histosols in Canaan Valley National Wildlife Refuge, West Virginia
}

\author{
Mitzy L. Schaney \\ Dissertation submitted to the \\ Eberly College of Arts and Sciences \\ at West Virginia University \\ in partial fulfillment of the requirements \\ for the degree of \\ Doctor of Philosophy \\ in \\ Geology \\ J. Steven Kite, Ph.D., Chair \\ James A. Thompson, Ph.D. \\ Amy Hessl, Ph.D. \\ Kathleen Counter Benison, Ph.D. \\ Katherine Heckman, Ph.D. \\ Department of Geology and Geography \\ Morgantown, West Virginia \\ 2019
}

Keywords: Holocene, Late Pleistocene, Peatlands, Histosols, Hypsithermal, Allegheny

Mountains, Appalachian Mountains, Canaan Valley, Soil Taxonomy, Pedomemory, Pedology

Copyright 2019 Mitzy L. Schaney 


\section{Abstract \\ Peatlands and Histosols in Canaan Valley National Wildlife Refuge, West Virginia Mitzy L. Schaney}

Canaan Valley in West Virginia contains a greater area of peatlands than any other locality in the mid-Atlantic Highlands. Extensive fieldwork focused on peat stratigraphy and pedology, combined with high-resolution radiocarbon dating, was used to evaluate five peatlands within Canaan Valley National Wildlife Refuge (CVNWR) in the central Appalachian Mountains. One hundred soil cores were profiled and described, 30 with laboratory data, including 52 radiocarbon dates. Calibrated basal peat dates among the five mapped peatlands indicate a late Pleistocene timeframe for the onset of peat genesis, ranging from $\sim 18,600$ to $\sim 15,200$ cal yr BP. The dates for peat initiation are older than those published previously from other central Appalachian Mountain peatlands. Peat accumulation rates varied from $0.02 \mathrm{~mm} / \mathrm{yr}$ to $1.34 \mathrm{~mm} / \mathrm{yr}$ with a mean of $0.14 \mathrm{~mm} / \mathrm{yr}$. Results of age-depth profiles show similar trends in peat accumulation: moderately high peat accumulation during the late Pleistocene, below average peat accumulation in the early Holocene, the slowest peat accumulation (if any) during the mid-Holocene, and rapid peat accumulation in the early late Holocene. Very few samples were collected correlating to the last 2,000 years; however, those few suggest a possible decrease in peat accumulation.

CVNWR peatlands hold pedomemory of latest Pleistocene and Holocene climatic fluctuations in the central Appalachian Mountains. The field investigation revealed a distinct pattern of organic soil horizons throughout five study peatlands. The anaerobic lower portion of the peat soil profile consists of varied thicknesses of a combination of hemic and sapric soil materials, characteristically layered as a hemic horizon, underlain by a sapric horizon, underlain 
by another hemic horizon, these also correlate with general trends in the age-depth plots. Late Pleistocene peat initiation and accumulation form the lower hemic horizon, correlating with general warming after the Last Glacial Maximum. Between 10,000 and 4,200 cal yr BP, low peat accumulation and decomposition of previously deposited peat prevailed, forming the sapric, or most decomposed, horizon in the anaerobic portion of the soil profile. This early to midHolocene interval of minimal accumulation and significant decomposition indicates a climatic change to a dryer environment. The upper hemic horizon within the anaerobic portion of the soil profile formed during the wetter early late Holocene. A sapric horizon at the water table is overlain by an aerobic fibric surface horizon in uppermost portion of the soil profile.

Soil profiles were classified according to Soil Taxonomy, and soil cores were mapped using the Soil Survey Manual. CVNWR Histosols were classified as Dysic, frigid Sapric Haplohemists and given an official series description and new soil series name of Canaan Valley peat. The five CVNWR peatland landforms are now mapped with a new map unit, Canaan Valley peat, moist, 0 to 3 percent slopes (map symbol CavA), totaling 246 hectares. These rare soils support unique ecosystems of high conservation value and ecological significance. 


\section{Table of Contents}

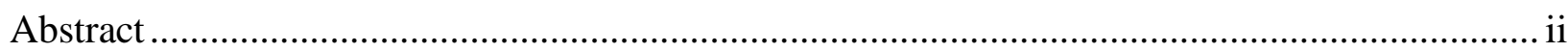

Peatlands and Histosols in Canaan Valley National Wildlife Refuge, West Virginia................... ii

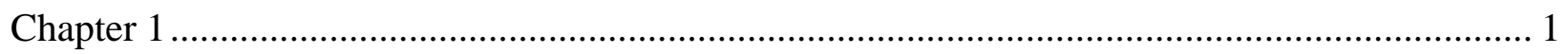

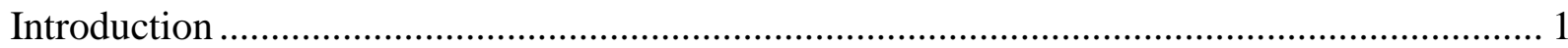

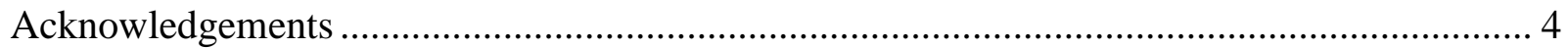

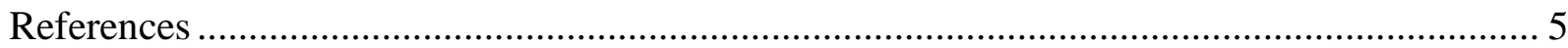

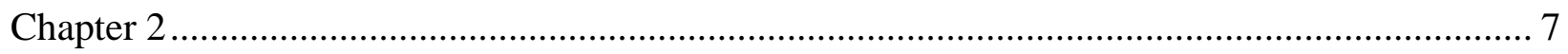

Radiocarbon dating peatland development: key steps in reconstructing past climate in the central

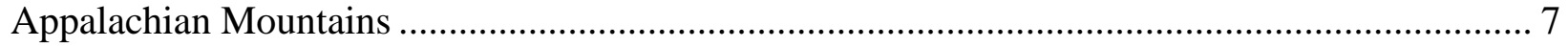

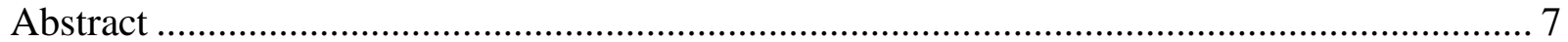

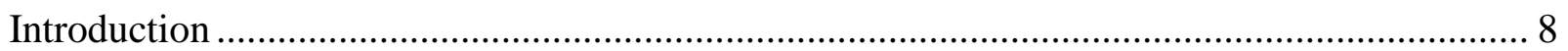

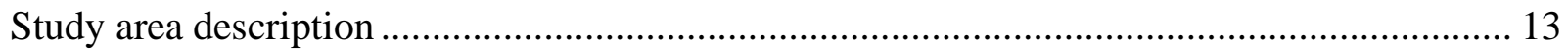

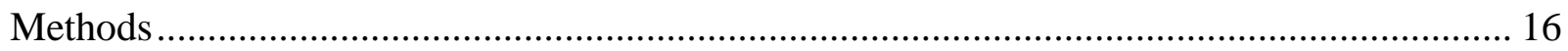

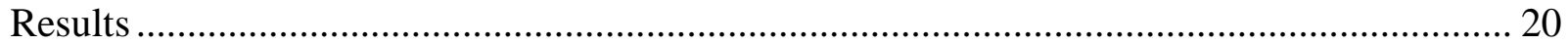

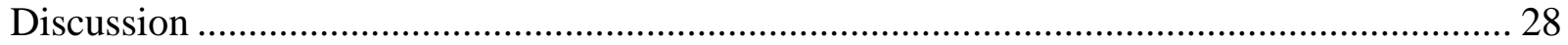

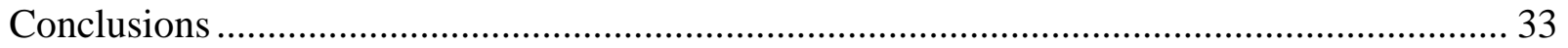

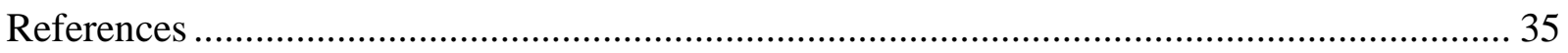

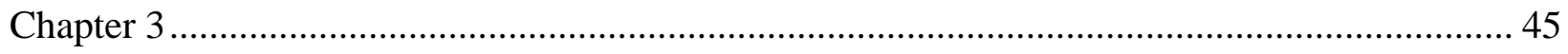

Evidence of mid-Holocene (Northgrippian Age) dry climate recorded in organic soil profiles in the central Appalachian Mountains. .................................................................................... 45

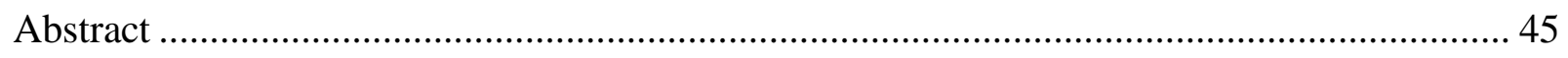

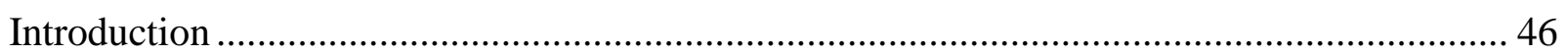

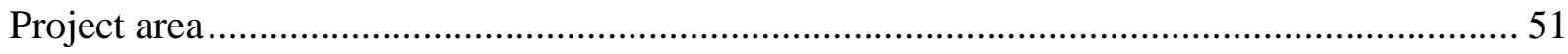

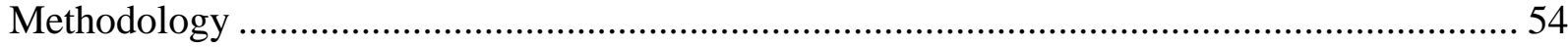

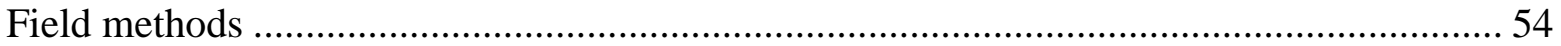

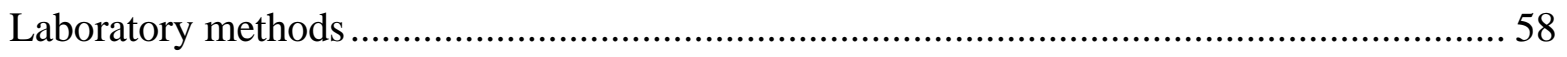

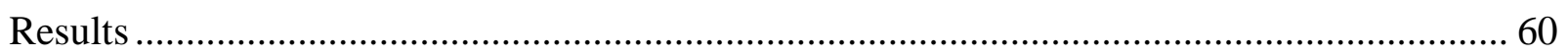

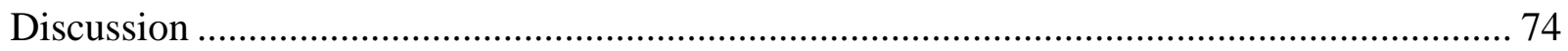

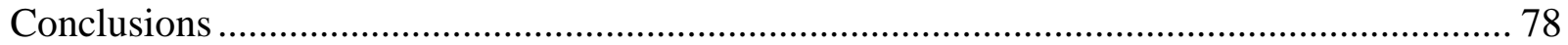

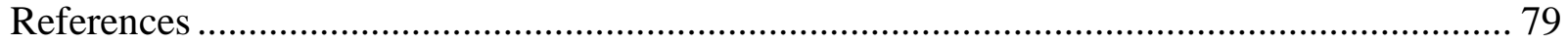

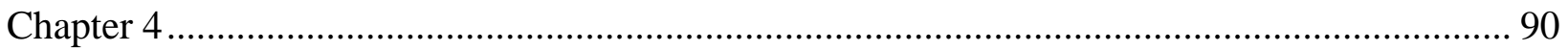


Classification and Mapping of Rare and Unique Histosols in the Central Appalachian Peatlands of Canaan Valley National Wildlife Refuge, West Virginia .................................................. 90

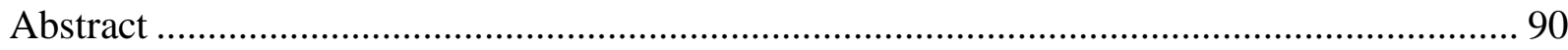

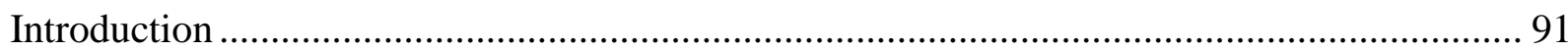

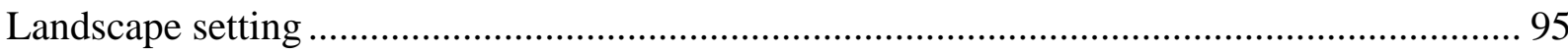

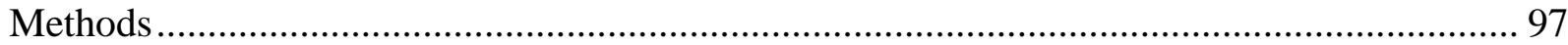

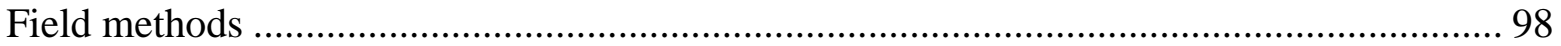

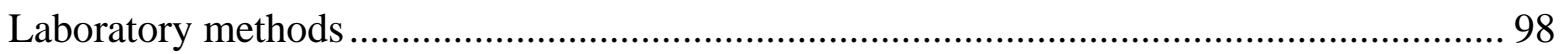

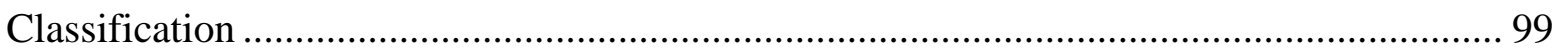

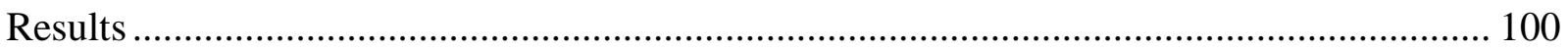

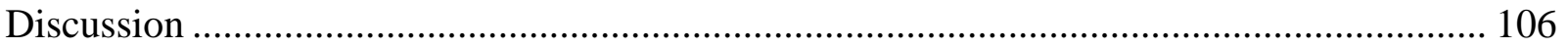

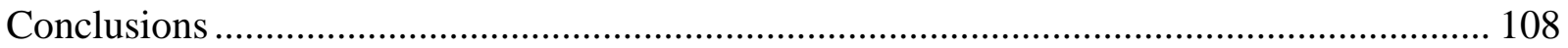

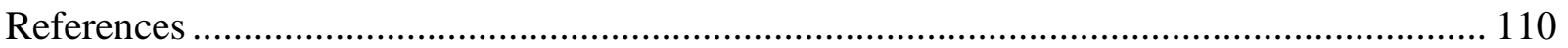

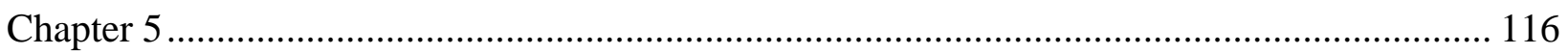

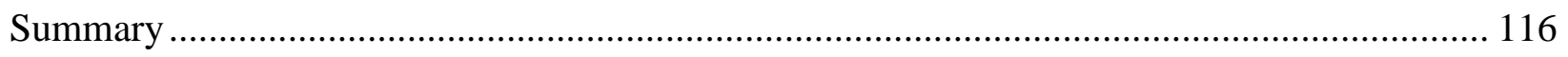

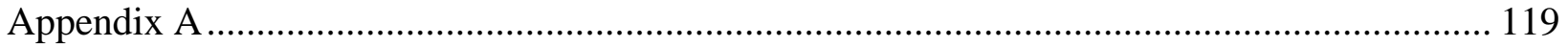

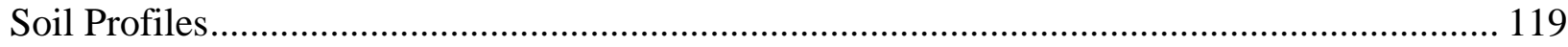

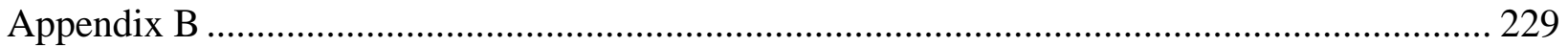

International Soil Radiocarbon Database QA/QC report.................................................... 229

\section{List of Figures and Tables by Chapter}

Figure 1-1. Landscape photograph of Canaan Valley National Wildlife Refuge................ 1 Figure 2- 1. The Allegheny Mountain Physiographic Section, shaded in gray, compiled from West Virginia (West Virginia Geologic and Economic Survey, 2017), Pennsylvania (Sevon, 2018), and Maryland (Reger and Cleaves, 2008) state physiographic maps. The star represents the location of Canaan Valley, 1 denotes Big Run Bog (Cramer Bog), 2 denotes Buckles Bog (The Glades), 3 denotes Cranesville Swamp, and 4 denotes Cranberry Glades........................ 13 Figure 2-2. Landscape photograph of the wetlands and peatlands located on the floor of Canaan

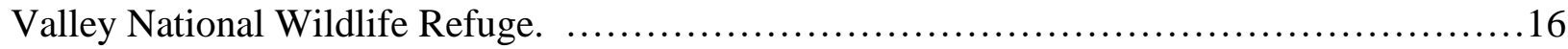

Figure 2- 3. Locations of 100 soils cores within the five mapped peatlands of CVNWR. Peatlands were numbered 1 through 5 for ease of fieldwork. Cores are numbered after a decimal following each peatland number. Aerial imagery obtained from National Agriculture Inventory Program 2007 by United States Department of Agriculture........2Error! Bookmark not defined. Figure 2- 4. Bayesian age-depth models constructed with modeling software Bacon for six cores (Cores 1.86, 2.09, 3.13, 4.19, 5.12, and 5.17). Transparent blue displays the $95 \%$ probability ranges of calibrated ages for individual ${ }^{14} \mathrm{C}$ dates. Red curve shows single 'best' model based on the weighted mean age for each depth. Gray shaded areas indicate the model's 
95\% probability intervals. Four temporal trends are generally distinguishable: rapid accumulation during the latest Pleistocene, lower accumulation rates in the early Holocene (Greenlandian Age), even lower accumulation rates during the mid-Holocene (Northgrippian Age), and the most rapid peat accumulation at the onset of the late Holocene (early Meghalayan Age)

Table 2- 1. Calibrated radiocarbon dates compiled from previously published research on other peatlands in the Allegheny Mountains.

Table 2- 2. Mapping results for the 100 soil cores in and around the five CVNWR peatlands.. 21 Table 2- 3. CVNWR radiocarbon dates and accumulation rates. Dated material consisted entirely of bulk peat samples. Accumulation rates were calculated as the thickness of accumulated peat divided by the corresponding interval between calibrated median radiocarbon ages. Samples 41 and 42 were reanalyzed due to a stratigraphic inversion, likely caused by procedural error. Dates on samples $41 *$ and $42 *$ were in expected stratigraphic order, so these age determinations were used in analysis and interpretation. The + symbol denotes radiocarbon dates with overlapping 95\% confidence intervals; mid-points were used to calculate a peat accumulation rates which were used for data interpretation.

Figure 3-1. Example of a Histosol profile from Core 5.1.

Figure 3- 2. Location of Canaan Valley National Wildlife Refuge boundary including Peatlands 1 through 5. Inset map displays CVNWR boundary within the Allegheny Mountain physiographic section (gray polygon). Aerial imagery obtained from the National Agriculture Inventory Program 2007 by United States Department of Agriculture.

Figure 3-3. Example of CVNWR fibric (decamping Sphagnum and brownish red material) and

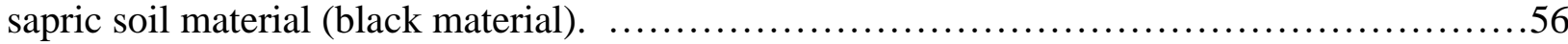

Figure 3-4. Example of CVNWR hemic soil material. ...............................57 Figure 3- 5. Five CVNWR peatlands with soil cores labeled by soil profile type: 2a. Peatland 1, 25 cores, dominated by Type B (SH) profiles; 2b. Peatland 29 cores; 2c. Peatland 319 cores, including all five soil types; 2d. Peatland 419 cores, including Type $\mathrm{C}$ (HSH) profiles clustered at the thickest peat, surrounded by Type E (HS) profiles, and a cluster of Type A $(\mathrm{H})$ profiles; 2e. Peatland 5, 16 cores, dominated by Type $\mathrm{C}(\mathrm{HSH})$ profiles. 65

Figure 3- 6. Possible development pathways for the five profiles types amongst CVNWR organic soil cores. Error! Bookmark not defined. Figure 3- 7. Soil profile of Core 4.02, representing Type A $(\mathrm{H})$ profiles............................... 69

Figure 3- 8. Soil profile of Core 1.86, representing Type B $(\mathrm{SH})$ profiles............................ 70 Figure 3- 9. Soil profile of Core 5.17, representing Type $\mathrm{C}$ (HSH) profiles........................... 71 Figure 3- 10. Soil profile of Core 2.07, representing Type D (S) profiles.............................. 72 Figure 3- 11. Soil profile of Core 3.17, representing Type E (HS) profiles. .......................... 73

Table 3- 1. CVNWR radiocarbon dates and accumulation rates. Dated material consisted entirely of bulk peat samples. Accumulation rates were calculated as the thickness of accumulated peat divided by the corresponding interval between calibrated median radiocarbon ages. Samples 41 and 42 were reanalyzed due to a stratigraphic inversion, likely caused by procedural error. Dates on samples $41 *$ and $42 *$ were in expected stratigraphic order, so these age determinations were used in analysis and interpretation. The + symbol denotes radiocarbon 
dates with overlapping 95\% confidence intervals; mid-points were used to calculate a peat accumulation rates which were used for data interpretation.............................................. 62

Table 3- 2. Profile type distribution amongst the five peatlands. ............................................ 64

Figure 4- 1. Canaan Valley represented by a star, with USDA Major land Resource Area (MLRA) 127 (from NRCS 2006 MLRA Geographic Database, version 4.2) shown shaded in gray.

Figure 4- 2. Peatlands 1 - 5 with previously mapped muck and peat (MP) soil map unit polygons outlined in black, and remapped Canaan Valley (CavA) soil map unit polygons in white. Aerial imagery obtained from the 2007 United States Department of Agriculture National Agriculture Inventory Program. 101

Figure 4- 3. The five mapped CVNWR peatlands with soil profiles labeled by classification. 103

Table 4- 1. Mapping results of the five peatlands. Parenthetic numbers following taxonomic classifications coordinate with the number scheme of Figure 4-3. 


\section{Chapter 1}

\section{Introduction}

The rare soils within the peatlands of Canaan Valley National Wildlife Refuge (CVNWR) support unique ecosystems of high conservation value and ecological significance. High-elevation peatlands of the central Appalachian Mountains are a southern extension of contemporary boreal ecosystems commonly associated with bogs and fens (Francl et al., 2004; Ingham, 1996; Snyder et al., 2006; Stewart and Nilsen, 1993; Stine et al., 2011; Whitehead, 1965). Peatlands act as archives of paleoenvironmental and paleoclimatic proxies, serve as both sinks $\left(\mathrm{CO}_{2}\right)$ and sources $\left(\mathrm{CO}_{2}\right.$ and $\left.\mathrm{CH}_{4}\right)$ of greenhouse gases, and represent a substantial worldwide carbon pool, making them scientifically valuable to understand past, current, and future global and local climates (Beilman et al., 2010; Chimner et al., 2014; Franzen et al., 2012; Ireland et al., 2013; Langdon et al., 2013; Loisel and Garneau, 2010; Warren et al., 2012; Yu et al., 2011, 2009; Zauft et al., 2010). Peatland soils, or Histosols, are not common in the Appalachian Mountains; before this study, CVNWR (Figure 1-1) peatlands soils had not been pedologically classified according to Soil Taxonomy and had been only briefly investigated several decades ago (Cameron, 1970).

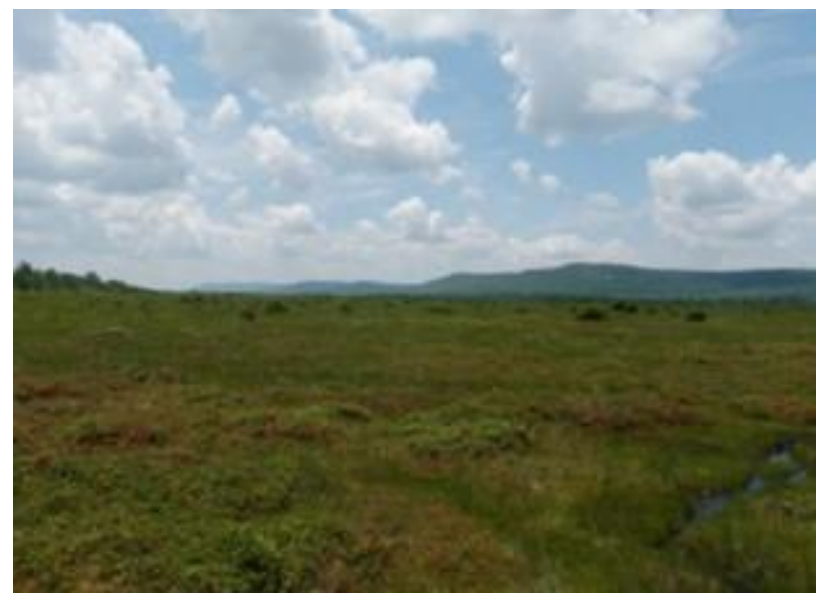

Figure 1-1. Landscape photograph of Canaan Valley National Wildlife Refuge Peatland 4 facing southwest. 
A career as an environmental scientist and previous graduate education in geomorphology and soils provided a professional working knowledge of wetlands, a passion for pedology, and an interest in geomorphic landform development. This dissertation research, which began in 2014, concentrated an interest in peatland soils and wetland landform development. Synthesizing data and report preparations have been in progress since this research began. Fieldwork commenced in the spring of 2014 and concluded in the summer of 2015. Radiocarbon dates and lab analysis were completed during the 2015-2016 academic year. Manuscript preparation has proceeded the following two years.

This dissertation has three broad foci organized into chapters 2 through 4 . Chapter 2 discusses the extensive fieldwork completed on these peatlands and the high-resolution radiocarbon-dated peat chronology developed from the peat cores; the Canaan Valley sequence is discussed in reference to chronologies from other Allegheny Mountain peatlands. Radiocarbon dates discussed in Chapter 2 will be archived in the International Soil Radiocarbon Database (ISRaD, https://international-soil-radiocarbon-database.github.io/ISRaD/). ISRaD has been developed as a collaboration between the U.S. Geological Survey Powell Center and the Max Planck Institute for Biogeochemistry. Database entry has been completed with a satisfactory quality assurance and quality control report (Appendix B); submission to ISRaD is awaiting a digital object identifier (doi) which will be received upon electronic theses and dissertation (ETD) submission of this dissertation to West Virginia University library system. This database includes profile descriptions for every single horizon recorded during this investigation, and laboratory data where sampled and analyzed. Chapter 2 entitled "Radiocarbon dating peatland development: key steps in reconstructing past climate in the central Appalachian Mountains" will be submitted for publication to Quaternary Science Reviews, published by 
Elsevier, a journal of Quaternary science that includes geomorphology, soil science, and, paleoclimatology and the full range of applicable dating methods.

Chapter 3 covers the distinct soil horizon pattern identified within a majority of the 88 Histosol soil profiles. Pedomemory of CVNWR Histosol stratigraphy revealed proxy evidence of a dryer climate during the mid-Holocene Climatic Optimum in the central Appalachian Mountains. Chapter 3 entitled "Evidence of mid-Holocene (Northgrippian Age) dry climate recorded in organic soil profiles in the central Appalachian Mountains" will be submitted for publication to Catena, an interdisciplinary journal of soil science, hydrology, and geomorphology focusing on geoecology and landscape evolution published by Elsevier.

Chapter 4 documents the classification and mapping of CVNWR Histosols in cooperation with Natural Resource Conservation Service (NRCS). It was important to the author to incorporate dissertation data into the NRCS, not only as an example of academic endeavors contributing federal agencies, but also to be incorporated into public knowledge. The 100 soil profile descriptions with laboratory data and taxonomic classifications are included in Appendix A of this document. The official series description (OSD) for the Canaan Valley soil series (https://soilseries.sc.egov.usda.gov/OSD_Docs/C/CANAAN_VALLEY.html) lists this dissertation as the primary reference; NRCS does not archive soil profile descriptions beyond the typical pedon described in the OSD. Chapter 4 entitled "Classification and Mapping of Rare and Unique Histosols in the Central Appalachian Peatlands of Canaan Valley National Wildlife Refuge, West Virginia" will be submitted for publication to Soil Science Society of America Journal the flagship journal of the Soil Science Society of America and publishes basic and applied soil research in agricultural, forest, wetlands, urban settings and more.

Chapter 5 is a brief summary and future research ideas. 


\section{Acknowledgements}

This work would not have been possible without the support, assistant, collaboration, and guidance from many mentors, colleagues, friends, and family. I would like to thank my committee chairman and primary advisor, Dr. J. Steven Kite, and my secondary advisor, Dr. James A. Thompson with the continual encouragement to complete this dissertation. They both assisted with field work, generation of ideas and theories, interpreting data, manuscript editing, guidance through the $\mathrm{PhD}$ process, and emotional support. I would also like to thank Dawn Washington of Canaan Valley National Wildlife Refuge for granting me permission to access, core, and dig in these unique ecosystems. CVNWR also provided field assistants and equipment. Radiocarbon analysis was funded by the U.S. Fish \& Wildlife Service for CVNWR and supported by the Radiocarbon Collaborative, which is jointly sponsored by the USDA Forest Service, University of California Irvine, and Michigan Tech University. That leads me to thanking Dr. Katherine Heckman, one of my committee members, and the liaison with the Radiocarbon Collaborative. Kate assisted with data interpretation and archiving for ISRaD. I would also like to thank Dr. Christopher Coughenour for timely completion of age-depth plots from the statistical modeling program Bacon in R.

Field and laboratory assistants were numerous over the years, came from a variety of organizations, and were thanked individually and en masse. Graduate and undergraduate students from West Virginia University and Indiana University of Pennsylvania participated for credit, experience, or kindness; it was much appreciated and impossible without their help. NRCS staff, particularly Skip Bell and Jason Teets, assisted with a variety of field work and with the formal designation of a new soil series. 
I would also like to thank Dr. Thomas Malterer, emeritus faculty from University of Minnesota Duluth, for the life-time loan of his personal peat auger.

Last and most important is thanking friends and family. A big thank you to my friends for understanding why you haven't seen much of me the last few years, for babysitting, and for allowing me to verbally and emotionally unload the stress. And thank you to my family, Chris and Matilda, and my extended family as well, your understanding, compassion, and support was crucial in completing.

\section{References}

Beilman, D. W., MacDonald, G. M., Yu, Z., 2010. The northern peatland carbon pool and the Holocene carbon cycle. PAGES 18(1):22-25.

Cameron, C. C., 1970. Peat resources of the unglaciated uplands along the Allegheny structural front in West Virginia, Maryland, and Pennsylvania. Geologic Survey Research 1970, Chapter D: U.S. Geologic Survey Professional Paper 700-D, 153-161.

Chimner, R. A., Ott, C. A., Perry, C. H., Kolka, R. K., 2014. Developing and Evaluating Rapid Field Methods to Estimate Peat Carbon. Wetlands 34(6):1241-1246.

Francl, K. E., Ford, W. M., Castleberry, S. B., 2004. Characterization of high elevation central Appalachian wetlands. Research Paper NE-725. USDA Forest Service, Northeastern Research Station, Newtown Square, PA, 26 p.

Franzen, L. G., Lindberg, F., Viklander, V., Walther, A., 2012. The potential peatland extent and carbon sink in Sweden, as related to the Peatland/Ice Age Hypothesis. Mines and Peat 10:119.

Ingham, M. E., 1996. The bog region of the Allegheny Mountains of West Virginia. Tampa, Florida: University of South Florida. M.A. thesis, 172 p.

Ireland, A. W., Booth, R. K., Hotchkiss, S. C., Schmitz, J. E., 2013. A comparative study of within-basin and regional peatland development: Implications for peatland carbon dynamics. Quaternary Science Reviews 61:85-95.

Langdon, P. G., Brown, A. G., Caseldine, C. J., Blockley, S. P. E., Stuijts, I., 2013.

Corrigendum to "Regional climate change from peat stratigraphy for the mid- to late Holocene in central Ireland" Quaternary International 268:145-155. 
Loisel, J., Garneau, M., 2010. Late Holocene paleoecohydrology and carbon accumulation estimates from two boreal peat bogs in eastern Canada: Potential and limits of multi-proxy archives. Palaeogeography, Palaeoclimatology, Palaeoecology 291:493-533.

Snyder, C. D., Young, J. A., Stout III, B. M., 2006. Aquatic habitats of Canaan Valley, West Virginia: Diversity and environmental threats. Northeastern Naturalist 13:333-352.

Stewart, C. N., Nilsen, E. T., 1993. Association of Edaphic Factors and Vegetation in Several Isolated Appalachian Peat Bogs. Bulletin of the Torrey Botanical Club 120(2):128-135.

Stine, M. B., Resler, L. M., Campbell, J. B., 2011. Ecotone characteristics of a southern Appalachian Mountain wetland. Catena 86:57-65.

Warren, M. W., Kauffman, J. B., Murdiyarso, D., Anshari, G., Hergoualc'H, K., Kurnianto, S., Purbopuspito, J., Gusmayanti, E., Afifudin, M., Rahajoe, J., Alhamd, L., Limin, S., Iswandi, A., 2012. A cost-efficient method to assess carbon stocks in tropical peat soil. Biogeosciences 9(11):4477-4485.

Whitehead, D. R., 1965. Palynology and Pleistocene phytogeography of unglaciated eastern United States. In: Wright, H.E.J., Frey, D.G. (eds.), The Quaternary of the United States. Princeton University Press, Princeton, NJ, p. 417-432.

Yu, Z., Beilman, D. W., Frolking, S., MacDonald, G. M., Roulet, N. T., Camill, P., Charman, D. J., 2011. Peatlands and Their Role in the Global Carbon Cycle. Eos, Transactions American Geophysical Union 92(12):97-98.

Yu, Z., Beilman, D. W., Jones, M. C., 2009. Sensitivity of Northern Peatland Carbon Dynamics to Holocene Climate Change. Carbon Cycling in Northern Peatlands Geophysical Monograph Series 184, p. 55-69.

Zauft, M., Fell, H., Glaßer, F., Rosskopf, N., Zeitz, J., 2010. Carbon storage in the peatlands of Mecklenburg-Western Pomerania, north-east Germany. Mires and Peat 6(4). http://mires-andpeat.net/pages/volumes/map06/map0604.php 


\title{
Chapter 2
}

Radiocarbon dating peatland development: key steps in reconstructing past climate in the central Appalachian Mountains

Mitzy L. Schaney ${ }^{\text {a } ~ *, ~ J . ~ S t e v e n ~ K i t e ~}{ }^{\text {b }}$, Katherine Heckman ${ }^{\text {c }}$, Christopher Coughenour ${ }^{\text {d, }}$ Christopher R. Schaney ${ }^{\mathrm{e}}$

${ }^{a}$ Geography Department, University of Pittsburgh at Johnstown, Krebs Hall 108D, 450

Schoolhouse Road, Johnstown, PA 15904

${ }^{\mathrm{b}}$ Department of Geology and Geography, West Virginia University, 330 Brooks Hall, P.O. Box 6300, Morgantown, WV 26506

${ }^{\mathrm{c}}$ USDA Forest Service, Climate, Fire \& Carbon Cycle Sciences, Northern Research Center, 410 MacInnes Drive, Houghton, MI, 49931

${ }^{\mathrm{d}}$ Department of Energy and Earth Resources, University of Pittsburgh at Johnstown, Krebs Hall 227B, 450 Schoolhouse Road, Johnstown, PA 15904

${ }^{\mathrm{e}}$ Department of Geography, Indiana University of Pennsylvania, 981 Grant Street, Indiana, PA 15705

*Corresponding author: m.schaney@pitt.edu

\begin{abstract}
Canaan Valley in West Virginia contains a greater area of peatlands than any other locality in the mid-Atlantic Highlands. Extensive fieldwork focused on peat stratigraphy, combined with high-resolution radiocarbon dating, was used to evaluate five peatlands within Canaan Valley National Wildlife Refuge (CVNWR). One hundred soil cores were profiled and described, 30 with laboratory analysis, including 52 radiocarbon dates. Calibrated basal peat dates from the five peatlands indicate the onset of peat genesis ranged from $\sim 18,600$ to $\sim 15,200$ cal yr BP. Basal peat dates on the two oldest cores are 1,800 to 2,200 older than published dates on peat initiation in any other Appalachian Mountain peatlands. Peat accumulation rates have
\end{abstract}


varied from $0.02 \mathrm{~mm} / \mathrm{yr}$ to $1.34 \mathrm{~mm} / \mathrm{yr}$, with a mean of $0.14 \mathrm{~mm} / \mathrm{yr}$. Results of age-depth profiles for six well-dated cores show similar trends in peat accumulation: rapid accumulation during the late Pleistocene (Heinrich Stadial 1, Bølling-Allerød interstadial, and Younger Dryas cold stadial), lower accumulation rates in the early Holocene (Greenlandian Age), even lower accumulation rates during the mid-Holocene (Northgrippian Age), and the most rapid peat accumulation at the onset of the late Holocene (early Meghalayan Age). A paucity of shallow peat dating younger than $2000 \mathrm{BP}$ may reflect a reduction in peat accumulation, or mixing of surface vegetation into near-surface soil horizons. The well dated and carefully described soil cores from CVNWR suggest a somewhat different peat development history than the process of terrestrialization previously proposed for other peatland ecosystems in the region.

Keywords: Holocene, Peatlands, Histosols, Mid-Holocene Climatic Optimum, Allegheny Mountains, Appalachian Mountains, Canaan Valley

\section{Introduction}

Central Appalachian peatlands are a southern extension of contemporary boreal ecosystems commonly associated with bogs and fens (Ingham, 1996; Stine et al., 2011; Whitehead, 1965). Allegheny Mountain peatlands range in size from a few hectares to a few hundred hectares (Ingham, 1996). Byers et al. (2007) placed Allegheny Mountain peatlands within the High Allegheny Wetland Ecological System. This ecological system occurs in a southwest-northeast trending band about $40 \mathrm{~km}$ wide and $200 \mathrm{~km}$ long along the Allegheny Mountain section of the Appalachian Plateaus physiographic province in unglaciated Pennsylvania, Maryland, and West Virginia (Cameron, 1970). 
Paleoecology and development history have been published previously for eight Allegheny Mountain peatlands (Figure 2-1): Big Run Bog (Larabee, 1986), Buckles Bog (Maxwell and Davis, 1972), Cranesville Swamp (Booth et al., 2016; Cox, 1968), four peatlands within Cranberry Glades (Bender et al., 1977, 1979; Darlington, 1943; Edens, 1973; Watts, 1979), and one peatland within Canaan Valley (Cameron, 1970), which was reexamined for this study. Most published Allegheny Mountain peatland chronologies share a proposed developmental history beginning in the late Pleistocene or Holocene as an open body of water accumulating limnic sediments that evolves through a transitional process of terrestrialization, first into a wetland accumulating organic-rich clays, and then into a peatland accumulating organic soils. The overall paleoecolgical record illustrates a general sequence of the vegetation changing from alpine tundra to open boreal forest, to closed boreal forest, and then finally transitioning into a mixed coniferous-deciduous forest that retained many boreal species. Before the logging era of the 1880 s to 1920 s, most vegetation in Allegheny Mountain peatlands consisted of hemlock (Tsuga canadensis), red spruce (Picea rubens Sarg.), and balsam fir (Abies balsamea (L.) Mill.) along the wetland edges with Rhododendron thickets in the understory, and Sphagnum and other mosses blanketing the forest and wetland floor (Francl et al., 2004). Allegheny Mountain peatlands have a rich biodiversity comprised partially of relict populations of once widespread boreal flora (Russell et al., 2009; Wieder et al., 1981). Biodiversity, prior to logging, resulted from dynamically changing landscapes and vegetation during the latest Pleistocene and Holocene climatic fluctuations (Barrington and Paris, 2007; Delcourt and Delcourt, 1986; Martin and Germain, 2016; Russell et al., 2009; Stine et al., 2011).

The primary goal of this research was to establish whether CVNWR, which contains the largest area of peatlands in the Allegheny Mountain physiographic region, has a similar 
developmental history as the previously studied peatlands in the region. Extensive fieldwork and high-resolution radiocarbon dating were used in evaluation of the climatic and ecosystem developmental history of five peatlands within CVNWR. Climate-ecosystem dynamics are an ever-increasing concern in the face of current and forecasted regional climate change. Preservation of unique ecosystems is the face of anthropogenic use and climate changes is also a concern for the Allegheny Mountain peatlands. Understanding past climate-ecosystem dynamics can be especially useful not only for land-use management decisions but also for understanding future climate-ecosystem dynamics.

Depositional environments are difficult to interpret and compare from previous studies of other peatlands in the region due to inconsistency in sediment profile descriptions and widely varying radiocarbon sample density; however, some generalizations are revealed. Published dates for the eight previously studied Allegheny Mountain peatlands outside Canaan Valley were calibrated for this publication using OxCal 4.2 and IntCal13 Northern Hemisphere calibration curve (Bronk Ramsey, 2009; Reimer et al., 2013) for ease of comparison (Table 2-1). Larabee (1986) reconstructed the development of Big Run Bog in Tucker County, West Virginia, with pollen and sediment analysis of one core. Big Run Bog began as an open body of water, evidenced by inorganic silty clay and clayey silt, from 20,400 to $\sim 19,700$ cal yr BP, transitioning into a wetland accumulating organic-rich clay around $\sim 17,000$ cal yr BP, and finally a peatland accumulating fibrous clayey peat by $\sim 5,400$ cal yr BP. Maxell and Davis (1972) completed a pollen and sediment analysis of one core from Buckles Bog (now known as The Glades) in Garrett County, Maryland. Buckles Bog began as an open body of water accumulating inorganic clay from $\sim 22,400$ to $\sim 21,000$ cal yr BP, transitioned into a wetland accumulating organic-rich clay beginning $~ 19,000 \mathrm{cal}$ yr BP, and into a peatland accumulating 
fibrous peat beginning at $\sim 15,000$ cal yr BP. Cox (1968), who completed a pollen analysis of one core from Cranesville Swamp, on the West Virginia-Maryland border, without the benefit of radiocarbon dates, surmised that a lake originated during the last glacial advance, and persisted until a warming trend facilitated the growth of Sphagnum and a transition to a peatland. Recently, Booth et al. (2016) examined two cores from Cranesville Swamp dating peat accumulating beginning at $\sim 1,000 \mathrm{cal}$ yr BP. Cranberry Glades in Pocahontas County, West Virginia, began as an open body of water accumulating clay and marl during the late Pleistocene (Darlington, 1943; Edens, 1973), transitioned into a wetland accumulating organic clay at $\sim 14,100$ cal yr BP and finally into a peatland accumulating peat beginning at $\sim 5,600 \mathrm{cal}$ yr BP (Bender et al., 1979, 1977; Watts, 1979). Darlington (1943) described over 150 cores from Cranesville Swamp, before the advent of radiocarbon dating. Cameron (1970) described peat and sedimentary deposits from 10 cores in one peatland in Canaan Valley in Tucker County, West Virginia (labeled by Cameron as peatland I-4, now labeled Peatland 5 in this study). Cameron (1970) obtained one radiocarbon date of $\sim 6,000$ cal yr BP from reed-sedge peat, not from the base of the organic soils. Collectively published data on Allegheny Mountain peatlands indicate a wide age range for the initiation of peat accumulation (Table 2-1), from $\sim 16,400 \mathrm{cal}$ yr BP (Cameron, 1970) and 15,000 cal yr BP (Maxwell and Davis, 1972) at Buckles Bog, 11,000 cal yr BP (Arnold and Libby, 1951) and 5,600 cal yr BP (Bender et al., 1979, 1977; Watts, 1979) at Cranberry Glades, 5,400 cal yr BP at Big Run Bog (Larabee, 1986), to 1,000 cal yr BP at Cranesville Swamp (Booth et al., 2016). 


\begin{tabular}{|c|c|c|c|c|c|c|c|c|c|}
\hline Laboratory ID & Location & Publication & Material dated & $\begin{array}{c}\text { Depth } \\
(\mathrm{cm})\end{array}$ & ${ }^{14} \mathrm{C}$ age & \pm & $\begin{array}{r}\text { intCal13 } \\
\text { Dates 95\% } \\
\text { inte } \\
\text { From }\end{array}$ & $\begin{array}{l}\text { orated } \\
\text { fidence }\end{array}$ & $\begin{array}{c}\text { median } \\
\text { cal yr BP }\end{array}$ \\
\hline USGS-W2255 & Canaan Valley & Cameron (1970) & reed-sedge peat & 132 & 5250 & 250 & 6627 & 5477 & 6029 \\
\hline A-4261 & Big Run Bog & Larabee (1986) & fibrous organic clay & 38 & 210 & 200 & 538 & 20 & 259 \\
\hline A-4260 & Big Run Bog & Larabee (1986) & clayey peat & 69 & 4680 & 110 & 5640 & 5046 & 5403 \\
\hline A-4264 & Big Run Bog & Larabee (1986) & slightly silty organic clay to fibrous organic clay & 112 & 10760 & 160 & 13057 & 12190 & 12674 \\
\hline A-4263 & Big Run Bog & Larabee (1986) & fibrous organic clay & 154 & 12600 & 170 & 15436 & 14153 & 14858 \\
\hline A-4259 & Big Run Bog & Larabee (1986) & fibrous organic clay to slightly silty organic clay & 197 & 13990 & 220 & 17584 & 16322 & 16975 \\
\hline A-4262 & Big Run Bog & Larabee (1986) & slightly silty clay & 212 & 16380 & 290 & 20487 & 19057 & 19776 \\
\hline A- 4258 & Big Run Bog & Larabee (1986) & clayey silt & 226 & 16910 & 340 & 21331 & 19591 & 20424 \\
\hline UGAMS 9988 & Cranesville Swamp (1) & Booth et al. (2015) & $\begin{array}{l}\text { Sphagnum } \\
\end{array}$ & 36 & 60 & 25 & 256 & 31 & 71 \\
\hline UGAMS 9987 & Cranesville Swamp (1) & Booth et al. (2015) & Charred Picea needles \& charcoal fragments & 41 & 190 & 25 & 296 & -4 & 178 \\
\hline UGAMS 10676 & Cranesville Swamp (1) & Booth et al. (2015) & Sphagnum and Picea needles & 57 & 230 & 20 & 307 & -3 & 284 \\
\hline UCIAMS 105039 & Cranesville Swamp (1) & Booth et al. (2015) & Picea needles & 71 & 950 & 20 & 926 & 796 & 851 \\
\hline UCIAMS 105038 & Cranesville Swamp (1) & Booth et al. (2015) & Picea needles & 76 & 1260 & 20 & 1274 & 1176 & 1223 \\
\hline UGAMS 12021 & Cranesville Swamp (1) & Booth et al. (2015) & wood fragment & 100 & 8610 & 25 & 9622 & 9528 & 9548 \\
\hline UCIAMS 105041 & Cranesville Swamp (2) & Booth et al. (2015) & Picea needles & 72 & 1255 & 20 & 1275 & 1097 & 1221 \\
\hline Y-2436 & Buckles Bog & Maxwell \& Davis (1972) & fibrous peat & 74 & 10530 & 160 & 12734 & 11848 & 12414 \\
\hline Y-2612 & Buckles Bog & Maxwell \& Davis (1972) & fibrous peat & 161 & 12320 & 200 & 15110 & 13781 & 14423 \\
\hline Y-2437 & Buckles Bog & Maxwell \& Davis (1972) & fibrous peat & 191 & 12640 & 200 & 15618 & 14157 & 14925 \\
\hline Y-2613 & Buckles Bog & Maxwell \& Davis (1972) & clayey gyttja & 242 & 15900 & 240 & 19805 & 18703 & 19210 \\
\hline Y-2619 & Buckles Bog & Maxwell \& Davis (1972) & clay & 249 & 17400 & 240 & 21719 & 20438 & 21031 \\
\hline Y-2438 & Buckles Bog & Maxwell \& Davis (1972) & clay & 255 & 18550 & 250 & 22996 & 21847 & 22418 \\
\hline USGS-W2253 & Buckles Bog & Cameron (1970) & peat & 234 & 13620 & 600 & 18196 & 14691 & 16465 \\
\hline C-336 & Cranberry Glades & Arnold and Libby (1951) & peat & 280 & 9423 & 840 & 13082 & 8775 & 10890 \\
\hline WIS-794 & Cranberry Glades & Watts (1979) & peat & 254 & 4900 & 65 & 5879 & 5476 & 5641 \\
\hline WIS-933 & Cranberry Glades & Watts (1979) & N/A & 327 & 7325 & 80 & 8329 & 7983 & 8135 \\
\hline WIS-785 & Cranberry Glades & Watts (1979) & organic clay & 363 & 12185 & 140 & 14759 & 13737 & 14112 \\
\hline
\end{tabular}

Table 2- 1. Calibrated radiocarbon dates compiled from previously published research on other peatlands in the Allegheny Mountains. 


\section{Study area description}

Canaan Valley, in Tucker County, West Virginia (Figure 2-1), is a high-elevation (980 m), breached anticlinal valley, associated with the Blackwater anticline. Headwaters of Blackwater River, within Cheat River watershed, drain most of the valley, including all study sites. Resistant Pottsville Sandstone caps surrounding mountain ridges with elevations of 1,100 to 1,300 m, Mauch Chunk siltstones, shales, and immature sandstones form the more easily erodible valley slopes, and Greenbrier Limestone and lower Mauch Chunk siltstones and shales underlie most of the valley floor (Fortney and Rentch, 2003; Matchen, 2015; Matchen et al., 1999). Projecting through limestone bottomlands in the valley center, a low, elongated ridge corresponds to the axis of the anticline; it is comprised of coarse-grained sandstone of the Price Formation (Matchen, 2015).

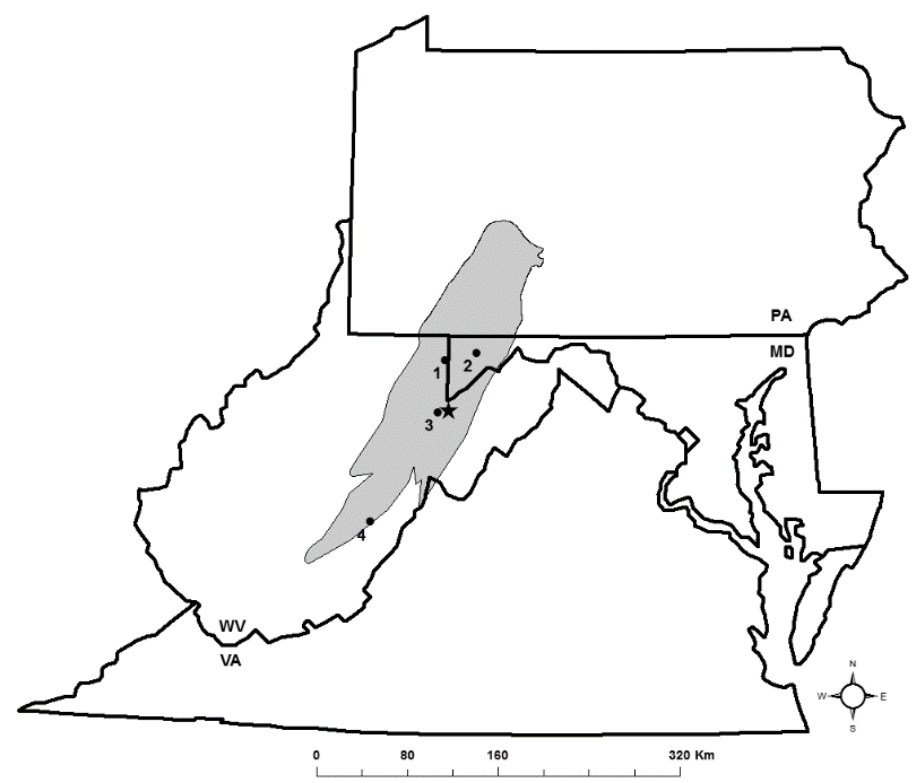

Figure 2- 1. The Allegheny Mountain Physiographic Section, shaded in gray, compiled from West Virginia (West Virginia Geologic and Economic Survey, 2017), Pennsylvania (Sevon, 2018), and Maryland (Reger and Cleaves, 2008) state physiographic maps. The star represents the location of Canaan Valley, 1 denotes Big Run Bog (Cramer Bog), 2 denotes Buckles Bog (The Glades), 3 denotes Cranesville Swamp, and 4 denotes Cranberry Glades. 
Canaan Valley lies within the Allegheny Mountain section of the Appalachian Plateaus physiographic province of unglaciated Pennsylvania, Maryland, and West Virginia (Cameron, 1970; Fenneman and Johnson, 1946; Reger and Cleaves, 2008; Sevon, 2018; West Virginia Geologic and Economic Survey, 2017). In general, the Allegheny Mountain section is higher in elevation than adjacent physiography and characterized by broad, open structural bedrock folds. Valley floors, and terraces and interfluves within broad valleys at high elevations (> $730 \mathrm{~m}$ ) of the plateau are typical locations for Allegheny Mountain peatlands (Cameron, 1970; Diehl and Behling, 1982). Some geographic niches in the Allegheny Mountain section are similar climatically to typical higher latitude boreal peatlands (Cameron, 1970) with high average annual precipitation and relatively low average annual temperature (Sencindiver et al., 2015; Walbridge, 1994; Western Regional Climate Center, 2016). Local topography, orographic precipitation, and the frost pocket effect where cold, nocturnal air drains downslope, decreasing temperatures on the valley floor, all accentuate the regional climatic conditions (Walbridge, 1994).

Structurally controlled bedrock valleys and concave bottomlands of the Allegheny Mountain section were formed by differential erosion. Impeded drainage developed within these valleys before the Holocene (Cameron, 1970), most likely by the blockage of drainage by periglacial activity (Larabee, 1986). Allegheny Mountain peatlands occur in or near the headwaters of first- or second-order streams or occur in specific geologic niches (Ingham, 1996), such as Canaan Valley located on a breached anticline. Cranesville Swamp is located behind a knickpoint of a dipping resistant strata cropping out within a drainageway. Resistant lithology in a dissected plateau created a local base level that controls low gradient wetlands like Big Run Bog (Diehl and Behling, 1982). Allegheny Mountain peatlands have also developed behind 
drainage impediments of alluvial levees (Darlington, 1943; Diehl and Behling, 1982; Rigg and Strausbaugh, 1949).

The floor of Canaan Valley contains one of the largest inland freshwater wetland ecosystems of peatlands, marshes, wet meadows, and shrub and forested wetlands in the eastern United States (Fortney and Rentch, 2003) (Figure 2-2). CVNWR encompasses the northern portion of Canaan Valley, protecting most of West Virginia's largest wetland complex, including the five mapped peatlands totaling 246 hectares. These five minerotrophic peatlands are characterized by exceptionally high biodiversity and conservation value (Byers et al., 2007), and have the largest peat deposits located in the unglaciated uplands along the Allegheny structural front in West Virginia, Maryland, and Pennsylvania (Cameron, 1970). These peatlands are ecologically classified as very poor fens, characterized as very acidic, moderately influenced by ground water, and dominated by sedges with a continuous carpet of Sphagnum (Kost et al., 2007). Peatlands, such as bogs and poor fens, may contain sensitive records of paleoclimate and paleoenvironment, including past moisture variations (Booth, 2010). Other peatlands are present in CVNWR and elsewhere in Canaan Valley. Unpublished soil profile descriptions for Thompson Enterprise Peat Mine as well as peatlands in Canaan Valley State Park at the southern end of the valley (Davis et al., 1999; Fedorko, 1993) indicate a different horizon sequence than found for this study. 


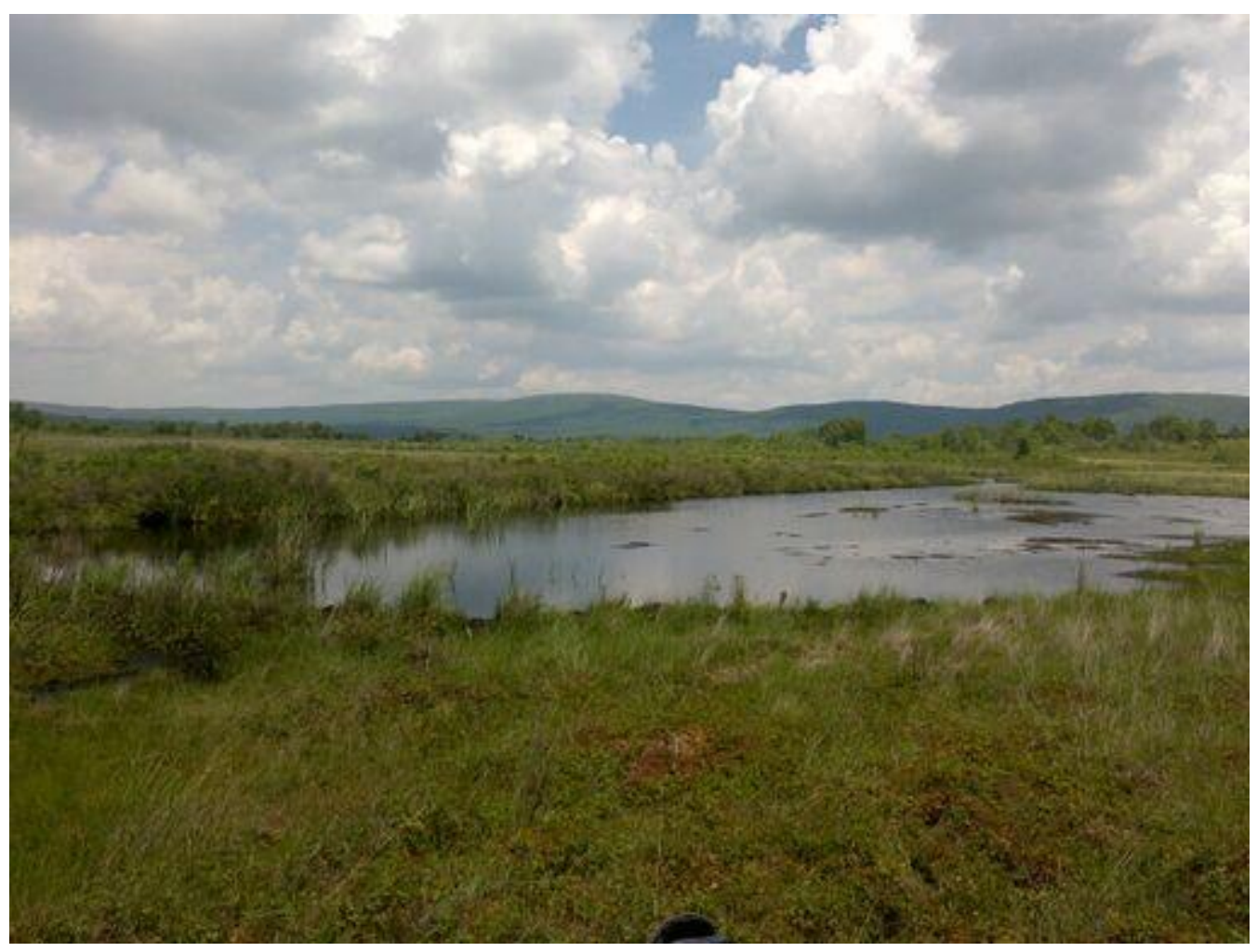

Figure 2-2. Landscape photograph of the wetlands and peatlands located on the floor of Canaan Valley National Wildlife Refuge.

\section{Methods}

Old Soil Conservation Service (SCS) map unit polygons, labeled as "muck and peat", provided an initial base map for this research; data for which were collected between 1959 and 1964 and mapped on 1956 and 1958 aerial photographs (Losche and Beverage, 1967). Cameron (1968) used the SCS polygons originally published in the 1925 Soil Survey of Tucker County (Phillips, 1925). The five muck and peat polygons were designated as Peatlands 1 through 5 for this study. Soil morphology was interpreted in the field by describing 100 soil cores throughout and around the five peatlands (Figure 2-3). Soil profiles were classified based upon the field descriptions and laboratory data, using NRCS Soil Taxonomy (Soil Survey Staff, 1999). 


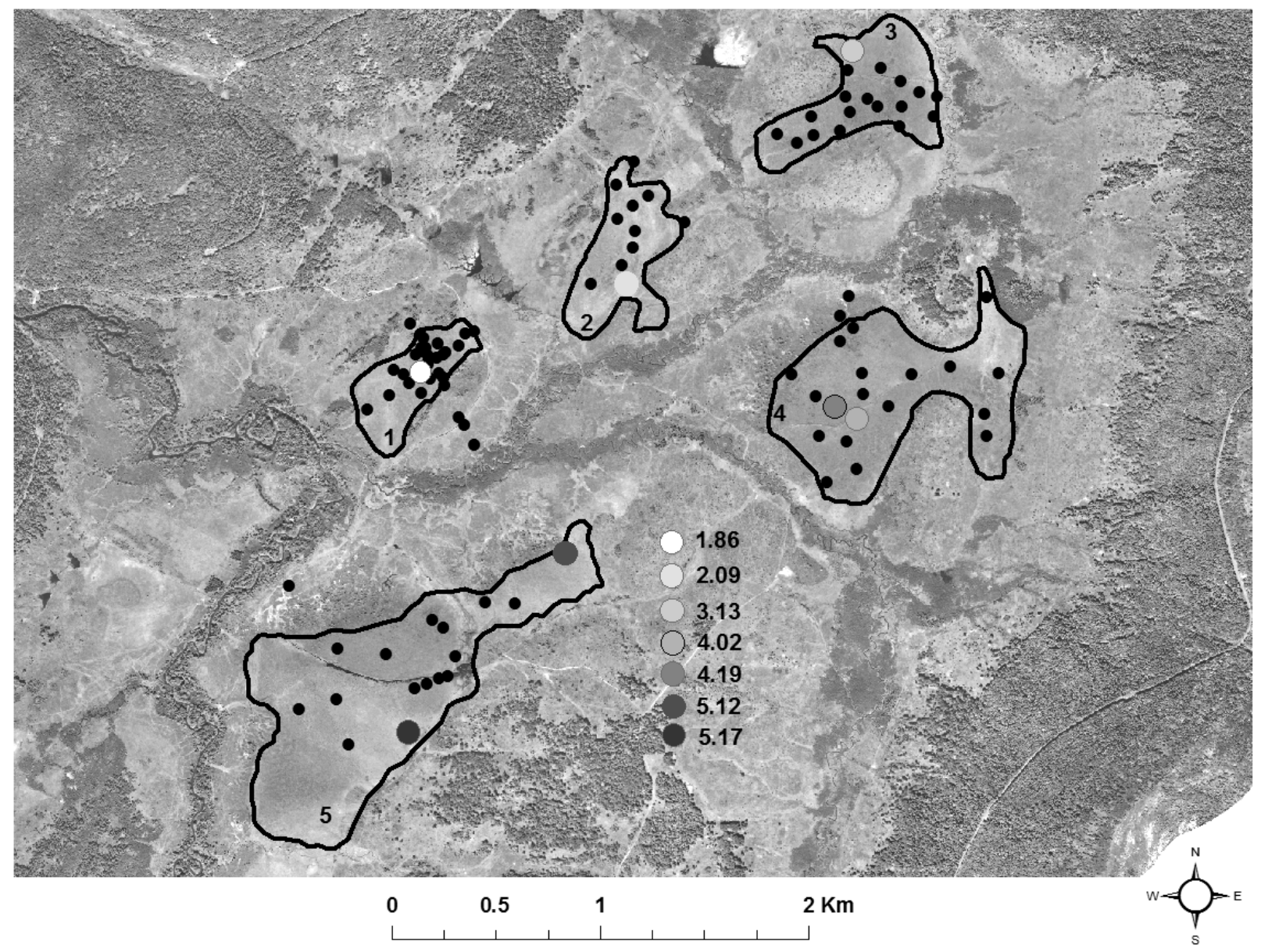

Figure 2- 3. Locations of 100 soils cores within the five mapped peatlands of CVNWR. Peatlands were numbered 1 through 5 for ease of fieldwork. Cores are numbered after a decimal following each peatland number. Aerial imagery obtained from National Agriculture Inventory Program 2007 by United States Department of Agriculture.

Soil core locations were chosen according to the "free survey" method of sampling soils, which involves the individual development and application of soil-landscape concepts based on the observation that soils will vary repetitively and predictably with geomorphology, topography, and other environmental characteristics (Carlisle et al., 1998). Location of cores was representative of the immediately surrounding terrain. Local small-scale hummocks and hollows were avoided, as well as locations of known anthropogenic disturbance. GPS coordinates, location notes, surface vegetation, and geomorphology, were recorded for each soil profile. 
Taking into account vegetation, ecosystem, microtopography, and water depth, a minimum of two specific core profile locations within each peatland were sampled for laboratory analysis. Locations selected for laboratory analysis were cored three separate times within a 30 $\mathrm{cm}$ radius of a central point. The first core at a location was used for soil profile description, the second core for bulk density samples, and the third core for all other laboratory analysis. Complete core samples were collected directly from a McCauley peat corer, placed in cut lengths of PVC tubes, wrapped with plastic, taped closed, and labeled.

CVNWR secured U.S. Fish and Wildlife Service funding to provide radiocarbon dating of 52 samples from 11 cores, in conjunction with the Radiocarbon Collaborative, jointly sponsored by the USDA Forest Service, University of California Irvine (previous mass spectrometry conducted at Lawrence Livermore National Lab in Livermore, California), and Michigan Technological University. Samples for radiocarbon dating were chosen and identified according to location and depth within the profile, focusing on basal peat dates, soil horizon breaks, and sedimentary sequence (Givelet et al., 2004; Piotrowska et al., 2010; Tuittila et al., 2013). The lack of compaction in the upper peat profile can introduce potential bias or incorrectly boost in average peat accumulation rate due to the topmost live and uncompacted section (Stivrins et al., 2011; Barber, 1981). Upper portions of the peat profiles were sparsely sampled for radiocarbon dating as to avoid uncertainty from anthropogenic disturbance and uncertainty from proximity to live plant tissue. Samples were treated with successive washes of $1 \mathrm{M} \mathrm{HCl}, 1 \mathrm{M} \mathrm{NaOH}$, and $1 \mathrm{M} \mathrm{HCl}$ at $95^{\circ} \mathrm{C}$, then rinsed twice with deionized water and dried. Bulk peat samples were graphitized in preparation for ${ }^{14} \mathrm{C}$ measurement at the Carbon, Water \& Soils Lab in Houghton, Michigan. Samples were dried, weighed into quartz tubes, and sealed under vacuum. Samples were combusted at $900^{\circ} \mathrm{C}$ for six hours with cupric oxide $(\mathrm{CuO})$ and 
silver $(\mathrm{Ag})$ in sealed quartz test tubes to form $\mathrm{CO}_{2}$ gas. The $\mathrm{CO}_{2}$ was reduced to graphite through heating at $570^{\circ} \mathrm{C}$ in the presence of hydrogen gas and an iron catalyst (Vogel et al., 1987). Graphite targets were sent to the Center for Accelerator Mass Spectrometry (CAMS) at Lawrence Livermore National Lab, analyzed for radiocarbon abundance (Davis et al., 1990), and corrected for mass-dependent fractionation using an estimated $\delta^{13} \mathrm{C}$ value of $-25 \%$, following Stuiver and Polach (1977). Dr. Vikas Agrawal of the IsoBioGeM laboratory in the Department of Geology and Geography at West Virginia University measured 14 of the 52 radiocarbon samples for $\delta^{13} \mathrm{C}$ to ensure consistency with the estimated $\delta^{13} \mathrm{C}$ value of $-25 \%$. Measured $\delta^{13} \mathrm{C}$ values ranged from $-24.1 \%$ o to $-28.4 \%$, sufficiently consistent to use the estimated $\delta^{13} \mathrm{C}$ value of $-25 \%$. Standard radiocarbon ages were calibrated to calendar dates (cal yr BP) using OxCal 4.2 and IntCal13 Northern Hemisphere calibration curve (Bronk Ramsey, 2009; Reimer et al., 2013).

Peat accumulation rates (Table 2-3) were calculated as peat horizon thickness divided by the corresponding time interval in calibrated radiocarbon dated calendar years (Borren et al., 2004). IntCal13 calibrated dates and known accumulation rates were used with Bacon in $\mathrm{R}$ to estimate the relationship between age and depth within the cores (Blaauw and Christen, 2011). Bacon, rather than simply finding a polynomial of best fit between sampled points, uses a Bayesian approach that incorporates other information about the samples that may be available to researchers. Bayesian methods incorporate "prior" knowledge to guide the analysis in making an assessment of final probability of occurrence. Prior information in age-depth modeling included changes in accumulation rate inferred on the basis of direct visual observation and soil profile analysis. Bacon assumes that accumulation rate is constant for a period of time and used the prior information in combination with sampled age-depth data (e.g. radiocarbon dates from different depths) to make the most probable "wiggle matches" between sampled points which 
themselves contain some uncertainty (Blaauw et al., 2007). As part of the interpolation scheme, Bacon employs an autoregressive (AR) model that computes accumulation rate as a function of pervious, underlying computed accumulation rates. The dependence of the model on previous values, the memory, defaulted to a reasonable value for peat soils (Blaauw and Christen, 2011). The AR model is also a function of a noise (residue) term, in this case a gamma function. This term determines the statistical distribution (probability density) of accumulation rates and determines how widely accumulation rates can differ from section to section within a core. The user-input shape factor controls the influence of user-input accumulation rate on the model. Low shape factor values allow for more variability in accumulation rates within a cored sequence. A shape factor of 2 was employed here and is generally considered reasonable for wetland ecosystems (e.g. Crann et al., 2015). Bacon simulates many runs using a self-adjusting Markov Chain Monte Carlo (MCMC) method, discarding implausible results such as negative accumulation rates. The most probable interpolation scenarios are reported $(95 \%$ prediction interval depicted in gray on Figure 2-4) and accumulation rates are gamma distributed after many simulated runs.

\section{Results}

The five NRCS “peat and muck” soil polygons, originally mapped as comprising a total of 187 hectares, were re-mapped in this investigation as 246 hectares. Organic soil thickness in the cores within the five CVNWR peatlands ranged from 0.4 to $3.0 \mathrm{~m}$; with most being less than $2.0 \mathrm{~m}$. Mapping results for the five peatlands are summarized in Table 2-2. 


\begin{tabular}{|l|r|r|r|r|r|}
\hline Peatland \# & $\begin{array}{r}\text { Originally } \\
\text { mapped as }\end{array}$ & Remapped as & $\begin{array}{r}\text { Number } \\
\text { of cores }\end{array}$ & $\begin{array}{r}\text { Average peat } \\
\text { thickness }\end{array}$ & $\begin{array}{r}\text { Maximum peat } \\
\text { thickness }\end{array}$ \\
\hline Peatland 1 & 9 hectares & 18 hectares & 32 & $\sim 100 \mathrm{~cm}$ & $174 \mathrm{~cm}$ \\
\hline Peatland 2 & 26 hectares & 26 hectares & 11 & $\sim 95 \mathrm{~cm}$ & $170 \mathrm{~cm}$ \\
\hline Peatland 3 & 21 hectares & 32 hectares & 19 & $\sim 125 \mathrm{~cm}$ & $170 \mathrm{~cm}$ \\
\hline Peatland 4 & 71 hectares & 69 hectares & 21 & $\sim 130 \mathrm{~cm}$ & $217 \mathrm{~cm}$ \\
\hline Peatland 5 & 60 hectares & 101 hectares & 17 & $\sim 170 \mathrm{~cm}$ & $296 \mathrm{~cm}$ \\
\hline
\end{tabular}

Table 2- 2. Mapping results for the 100 soil cores in and around the five CVNWR peatlands.

Eighty-eight of the 100 soil profiles were classified as Histosols; 12 were classified as Entisols, were excavated outside of the peatland boundary for mapping purposes, and will not be discussed further. Silty and clayey sediments immediately underlie the peat soils in 61 of the 88 Histosol soil cores, whereas sandy sediments underlie peat soils in 12 profiled Histosols. The 12 soil cores with underlying sandy sediments varied spatially; some were near streams, some near higher elevation bedrock, and others in the center of the peatlands. No soil cores contained the interbedded organic sediments providing evidence of a gradual transition from open water to peatland. Underlying mineral sediment was not retrieved in 15 Histosol profiles.

Radiocarbon dating results are listed in Table 2-3. Forty-eight of the original 50 dates were consistent with stratigraphic order, but ages on samples CAMS-172765 and CAMS-172766 in Core 5.17 were inverted, most likely due to error at some step in the sampling or submission process. The problematic horizons in Core 5.17 were re-sampled and re-analyzed, yielding dates CAMS-174232 and CAMS-174233 that were consistent with stratigraphic order. Only age determinations on the reanalyzed samples were used for interpretation, peat accumulation rate calculation, and age-depth plots.

Each of the five CVNWR peatlands had two basal peat age determinations taken from different cores, except for Peatland 4, which had three. Four cores had only a basal peat date as 
shown in Table 2-3. Sequential radiocarbon dates were obtained for seven cores. Basal peat samples were taken from immediately above lithologic breaks from underlying mineral soil to overlying organic soil. Initiation of peat accumulation was relatively consistent throughout the five study areas with nine basal peat dates from the five peatlands ranging from $\sim 18,600$ to 15,200 cal yr BP, during or immediately after Heinrich Stadial 1, a timespan marked by retreat of the Lake Huron-Erie Lobe of the Laurentian Ice Sheet had already retreated $>200 \mathrm{~km}$ north of 


\begin{tabular}{|c|c|c|c|c|c|c|c|c|c|}
\hline \multirow[t]{2}{*}{$\begin{array}{r}\text { Laboratory } \\
\text { ID }\end{array}$} & \multirow[t]{2}{*}{ Sample \# } & \multirow[t]{2}{*}{ Core \# } & \multirow[t]{2}{*}{ Depth (cm) } & \multicolumn{2}{|c|}{ Standard Radiocarbon Age } & \multicolumn{2}{|c|}{$\begin{array}{r}\text { intCal13 } \\
\text { Calibrated } \\
\text { Dates } 95 \% \\
\text { confidence } \\
\text { interval }\end{array}$} & \multirow[t]{2}{*}{$\begin{array}{r}\text { Median } \\
\text { cal yr BP }\end{array}$} & \multirow[t]{2}{*}{$\begin{array}{r}\text { Accumulation } \\
\text { Rate mm/yr }\end{array}$} \\
\hline & & & & ${ }^{14} \mathrm{C}$ age & \pm & From & To & & \\
\hline CAMS-171742 & 25 & 1.82 & $128-130$ & 12810 & 40 & 15449 & 15109 & 15258 & \\
\hline CAMS-172756 & 32 & 1.86 & $2-4$ & 1225 & 30 & 1260 & 1065 & 1153 & 0.05 \\
\hline CAMS-172757 & 33 & 1.86 & $40-42$ & 7880 & 35 & 8953 & 8587 & 8675 & 0.08 \\
\hline CAMS-172762 & 38 & 1.86 & $59-61$ & 9600 & 30 & 11128 & 10774 & 10928 & 0.18 \\
\hline CAMS-172763 & 39 & 1.86 & $86-88$ & 10475 & 35 & 12560 & 12147 & 12451 & $0.82_{+}$ \\
\hline CAMS-172764 & 40 & 1.86 & $100-102$ & 10635 & 30 & 12690 & 12559 & 12621 & $0.08_{+}$ \\
\hline CAMS-171738 & 21 & 1.86 & $127-129$ & 13155 & 40 & 16002 & 15637 & 15807 & \\
\hline CAMS-171739 & 22 & 2.05 & $119-121$ & 15045 & 40 & 18435 & 18099 & 18284 & \\
\hline CAMS-172760 & 36 & 2.09 & $15-17$ & 3550 & 35 & 3960 & 3720 & 3844 & 0.05 \\
\hline CAMS-172761 & 37 & 2.09 & $40-42$ & 8035 & 35 & 9021 & 8775 & 8909 & 0.04 \\
\hline CAMS- 172758 & 34 & 2.09 & $65-67$ & 12455 & 45 & 14961 & 14251 & 14598 & 0.16 \\
\hline CAMS-172759 & 35 & 2.09 & $80-82$ & 12985 & 40 & 15732 & 15315 & 15528 & 0.33 \\
\hline CAMS-171737 & 20 & 2.09 & $92-94$ & 13225 & 40 & 16069 & 15730 & 15896 & \\
\hline CAMS-172750 & 26 & 3.13 & $11-13$ & 1925 & 30 & 1947 & 1817 & 1873 & 0.11 \\
\hline CAMS-170482 & 10 & 3.13 & $27-29$ & 3155 & 30 & 3450 & 3269 & 3382 & 0.45 \\
\hline CAMS-172751 & 27 & 3.13 & $50-52$ & 3590 & 30 & 3977 & 3833 & 3894 & 0.07 \\
\hline CAMS-170483 & 11 & 3.13 & $64-66$ & 5180 & 30 & 5991 & 5905 & 5936 & 0.02 \\
\hline CAMS-172752 & 28 & 3.13 & $75-77$ & 10095 & 40 & 11954 & 11404 & 11687 & 0.06 \\
\hline CAMS-172753 & 29 & 3.13 & $83-85$ & 11085 & 35 & 13063 & 12824 & 12960 & 0.20 \\
\hline CAMS-170484 & 12 & 3.13 & $94-96$ & 11680 & 30 & 13570 & 13445 & 13510 & 0.08 \\
\hline CAMS-172754 & 30 & 3.13 & $120-122$ & 13815 & 40 & 16946 & 16488 & 16715 & 0.23 \\
\hline CAMS-170485 & 13 & 3.13 & $165-167$ & 15375 & 35 & 18759 & 18544 & 18653 & \\
\hline CAMS- 171740 & 23 & 3.14 & $121-123$ & 13870 & 40 & 17009 & 16573 & 16802 & \\
\hline
\end{tabular}

Table 2- 3. CVNWR radiocarbon dates and accumulation rates. Dated material consisted entirely of bulk peat samples. Accumulation rates were calculated as the thickness of accumulated peat divided by the corresponding interval between calibrated median radiocarbon ages. Samples 41 and 42 were reanalyzed due to a stratigraphic inversion, likely caused by procedural error. Dates on samples $41^{*}$ and $42 *$ were in expected stratigraphic order, so these age determinations were used in analysis and interpretation. The + symbol denotes radiocarbon dates with overlapping $95 \%$ confidence intervals; mid-points were used to calculate a peat accumulation rates which were used for data interpretation. 


\begin{tabular}{|c|c|c|c|c|c|c|c|c|c|}
\hline \multirow[t]{2}{*}{$\begin{array}{r}\text { Laboratory } \\
\text { ID }\end{array}$} & \multirow[t]{2}{*}{ Sample \# } & \multirow[t]{2}{*}{ Core \# } & \multirow[t]{2}{*}{$\begin{array}{r}\text { Depth } \\
(\mathbf{c m})\end{array}$} & \multicolumn{2}{|c|}{ Standard Radiocarbon Age } & \multicolumn{2}{|c|}{$\begin{array}{r}\text { intCal13 } \\
\text { Calibrated } \\
\text { Dates } 95 \% \\
\text { confidence } \\
\text { interval }\end{array}$} & \multirow[t]{2}{*}{$\begin{array}{r}\text { Median } \\
\text { cal yr BP }\end{array}$} & \multirow[t]{2}{*}{$\begin{array}{r}\text { Accumulation } \\
\text { Rate } \mathbf{m m} / \mathbf{y r}\end{array}$} \\
\hline & & & & ${ }^{14} \mathrm{C}$ age & \pm & From & To & & \\
\hline CAMS-170478 & 6 & 4.02 & $7-9$ & 420 & 35 & 530 & 326 & 486 & 0.06 \\
\hline CAMS-170479 & 7 & 4.02 & $17-20$ & 2130 & 30 & 2299 & 2001 & 2111 & 0.44 \\
\hline CAMS- 170480 & 8 & 4.02 & $76-79$ & 3240 & 30 & 3560 & 3388 & 3460 & 0.35 \\
\hline CAMS-170481 & 9 & 4.02 & $117-120$ & 4095 & 35 & 4814 & 4446 & 4607 & \\
\hline CAMS-172755 & 31 & 4.09 & $151-152$ & 4380 & 40 & 5212 & 4852 & 4942 & \\
\hline CAMS-172770 & 46 & 4.19 & $30-32$ & 2490 & 30 & 2730 & 2460 & 2584 & 0.61 \\
\hline CAMS-172771 & 47 & 4.19 & $60-62$ & 2925 & 30 & 3164 & 2971 & 3072 & 0.52 \\
\hline CAMS-172772 & 48 & 4.19 & $80-82$ & 3235 & 30 & 3558 & 3385 & 3453 & 0.58 \\
\hline CAMS-172773 & 49 & 4.19 & $120-122$ & 3775 & 35 & 4281 & 3992 & 4146 & 0.05 \\
\hline CAMS-172774 & 50 & 4.19 & $165-167$ & 11235 & 35 & 13164 & 13041 & 13097 & 0.21 \\
\hline CAMS-171741 & 24 & 4.19 & $211-213$ & 12850 & 40 & 15545 & 15160 & 15315 & \\
\hline CAMS-170473 & 1 & 5.12 & $16-20$ & 2080 & 30 & 2140 & 1952 & 2050 & 0.64 \\
\hline CAMS-170474 & 2 & 5.12 & $51-53$ & 2495 & 30 & 2732 & 2466 & 2585 & 1.34 \\
\hline CAMS-170475 & 3 & 5.12 & $82-85$ & 2725 & 30 & 2873 & 2761 & 2817 & 0.04 \\
\hline CAMS-170476 & 4 & 5.12 & $114-116$ & 9010 & 30 & 10235 & 10170 & 10204 & 0.15 \\
\hline CAMS-170477 & 5 & 5.12 & $197-199$ & 13105 & 35 & 15940 & 15540 & 15733 & \\
\hline CAMS-171732 & 15 & 5.17 & $18-20$ & 2070 & 30 & 2123 & 1950 & 2039 & 0.68 \\
\hline CAMS-171733 & 16 & 5.17 & $70-72$ & 2705 & 30 & 2857 & 2756 & 2804 & 0.39 \\
\hline CAMS-172765 & 41 & 5.17 & $85-87$ & 3800 & 30 & 4288 & 4088 & 4187 & \\
\hline CAMS-174232 & $41^{*}$ & 5.17 & $82-84$ & 2970 & 30 & 3230 & 3007 & 3135 & 0.37 \\
\hline CAMS-172766 & 42 & 5.17 & $120-122$ & 2930 & 30 & 3169 & 2974 & 3080 & \\
\hline CAMS-174233 & $42 *$ & 5.17 & $122-124$ & 3820 & 40 & 4406 & 4091 & 4217 & 0.07 \\
\hline CAMS-172767 & 43 & 5.17 & $130-132$ & 4580 & 30 & 5447 & 5066 & 5302 & $0.63_{+}$ \\
\hline CAMS-172768 & 44 & 5.17 & $140-142$ & 4720 & 45 & 5584 & 5322 & 5460 & $0.04_{+}$ \\
\hline CAMS-171736 & 19 & 5.17 & $161-163$ & 9160 & 45 & 10483 & 10231 & 10323 & 0.12 \\
\hline CAMS-172769 & 45 & 5.17 & 173-175 & 9930 & 30 & 11590 & 11241 & 11312 & 0.12 \\
\hline CAMS-171735 & 18 & 5.17 & $196-198$ & 11360 & 35 & 13290 & 13115 & 13203 & 0.28 \\
\hline CAMS-171734 & 17 & 5.17 & $225-227$ & 12310 & 35 & 14531 & 14075 & 14237 & 0.55 \\
\hline CAMS-171731 & 14 & 5.17 & $288-290$ & 12890 & 40 & 15598 & 15210 & 15382 & \\
\hline
\end{tabular}

Table 2-3. CVNWR radiocarbon dates and accumulation rates (continued). 
its late glacial maximum position (Heath et al., 2018). The only exceptions occur in two cores from a small area in Peatland 4, where basal peat ages were $\sim 4,900$ and $\sim 4,600$ cal yr BP. Microtopography and hydrology of peatland surfaces and edaphic hydrology are irregular and dynamic (Ammann et al., 2013; Clymo, 1984; Holden, 2005) and were presumably the cause of two of the 11 basal peat dates being drastically younger. Core 3.13 had nine sequential radiocarbon dates that included a long interval from $\sim 11,700$ to $\sim 5,900$ cal yr BP, within only 10 $\mathrm{cm}$ of net peat accumulation. Core 5.17 had 11 sequential radiocarbon dates that included an interval from $\sim 10,300$ to $\sim 5,400 \mathrm{cal} \mathrm{yr} \mathrm{BP}$, with less than $20 \mathrm{~cm}$ of net peat accumulation. These long intervals of very low peat accumulation in the two best-dated CVNWR Histosol cores span most of the early and middle Holocene (Chapter 3).

Accumulation rates (Table 2-3) and age-depth plots of the seven sequentially dated cores displayed varied accumulation rates in response to latest Pleistocene and Holocene climatic changes (Figure 2-4). Peat accumulation rates varied from a maximum of $1.34 \mathrm{~mm} / \mathrm{yr}$ to a minimum of $0.02 \mathrm{~mm} / \mathrm{yr}$, with a mean of $0.14 \mathrm{~mm} / \mathrm{yr}$ (calculated as the mean of the overall whole core rates at each core with sequential dates).

Four general trends are apparent in the age-depth plots (Figure 2-4) and accumulation rates (Table 2-3). Peat accumulation rates between $\sim 15,800$ and $\sim 12,500$ cal yr BP averaged $0.24 \mathrm{~mm} / \mathrm{yr}$. Net peat accumulation declined to a mean of $0.11 \mathrm{~mm} / \mathrm{yr}$ between $\sim 11,700$ and $\sim 8,600$ cal yr BP generally correlating to the early Holocene Greenlandian Age. Few radiocarbon dates were obtained on peat of mid-Holocene Northgrippian Age, hence only two cores include well-constrained mid-Holocene peat accumulation rates. Core 3.13 had a peat accumulation rate of $0.02 \mathrm{~mm} / \mathrm{yr}$ between $\sim 11,700$ and $\sim 5,900$ cal $\mathrm{yr} \mathrm{BP}$, and Core $5.17 \mathrm{had}$ a peat accumulation rate of $0.04 \mathrm{~mm} / \mathrm{yr}$ between $\sim 10,300$ and $\sim 5,400 \mathrm{Cal} \mathrm{yr} \mathrm{BP}$. These appear to 

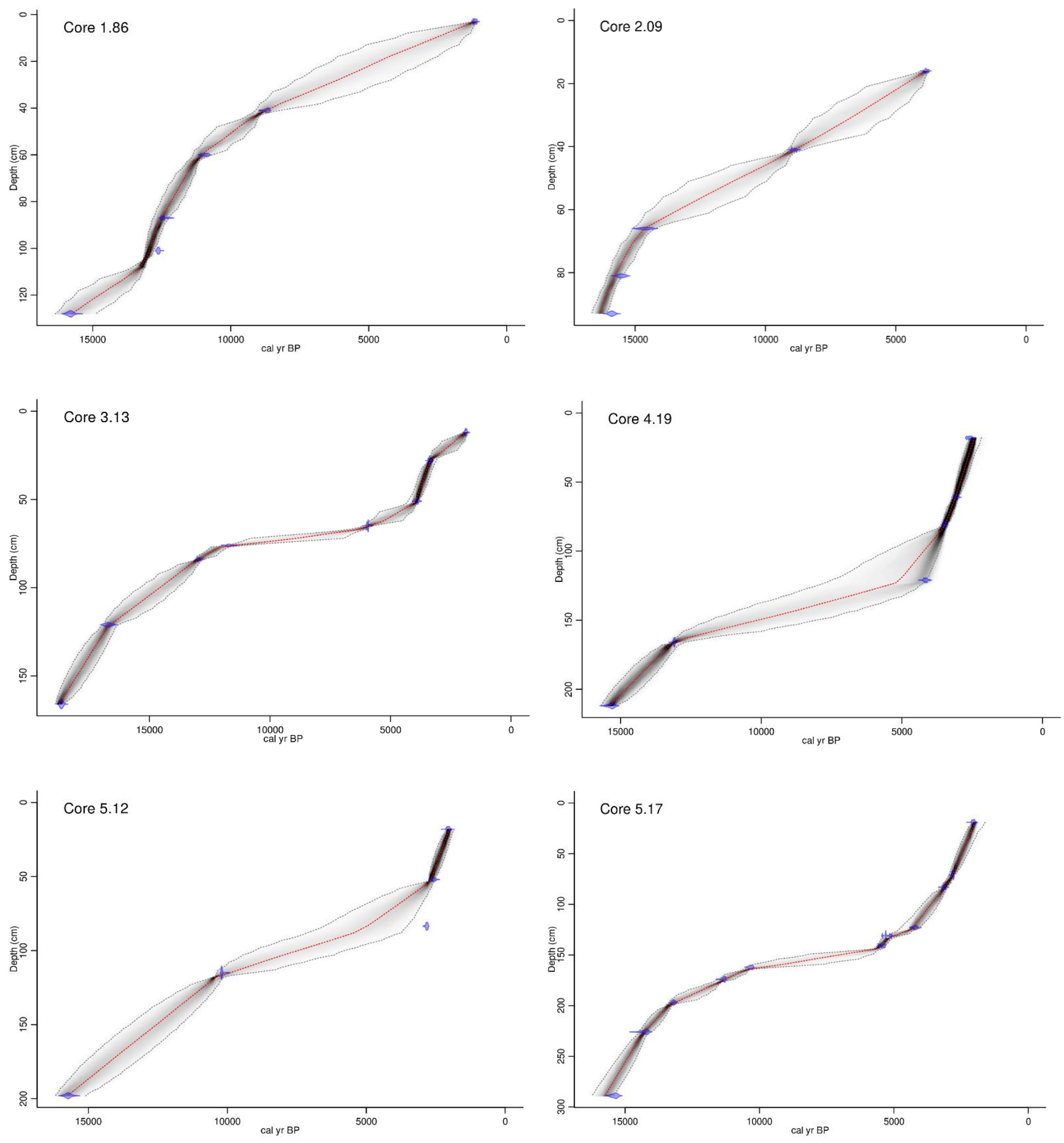


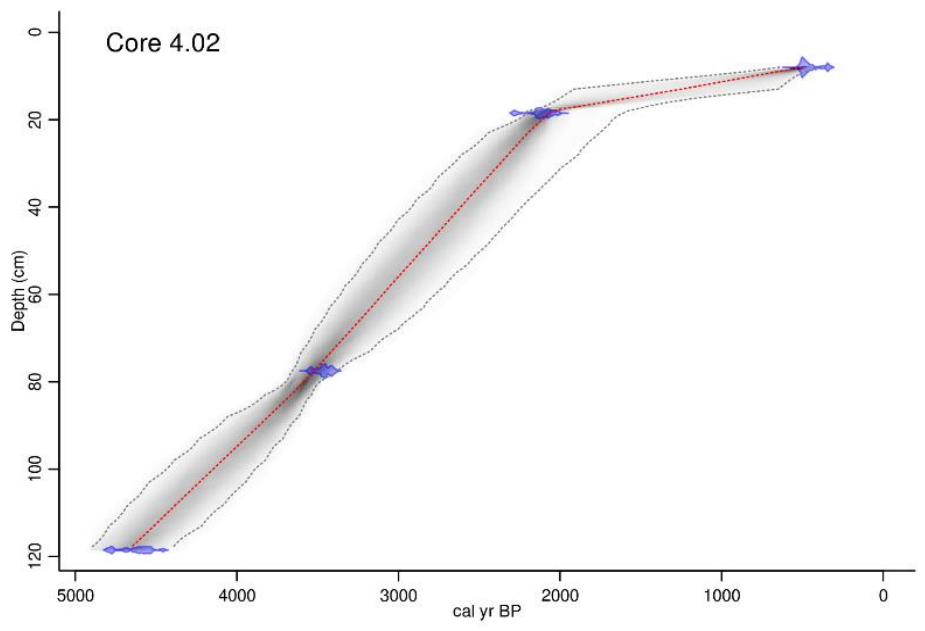

Figure 2- 4. Bayesian age-depth models constructed with modeling software Bacon for seven cores (Cores $1.86,2.09,3.13,4.02,4.19,5.12$, and 5.17). Note that ${ }^{14} \mathrm{C}$ dates show peat in Core 4.02 dates only from the mid-Holocene and Late Holocene. Transparent blue displays the 95\% probability ranges of calibrated ages for individual ${ }^{14} \mathrm{C}$ dates. Red curve shows single 'best' model based on the weighted mean age for each depth. Gray shaded areas indicate the model's 95\% probability intervals. Four temporal trends are generally distinguishable: rapid accumulation during the latest Pleistocene, lower accumulation rates in the early Holocene (Greenlandian Age), even lower accumulation rates during the mid-Holocene (Northgrippian Age), and the most rapid peat accumulation at the onset of the late Holocene (early Meghalayan Age). 
be the lowest rates of any time since the onset of peat accumulation, a trend reinforced by the scarcity of peat of this age. Exceptionally high peat accumulation rates between $\sim 4,200$ and $\sim 2,000 \mathrm{cal}$ yr BP averaged $0.50 \mathrm{~mm} / \mathrm{yr}$ coeval with the onset of the late Holocene Meghalayan Age. The last 2,000 years of peat development in CVNWR was represented by only three dates, but generally show very low peat accumulations rates averaging $0.08 \mathrm{~mm} / \mathrm{yr}$ which may reflect a reduction in peat accumulation, or mixing of surface vegetation into near-surface soil horizons.

\section{Discussion}

Motivation for this research was to reassess Allegheny Mountain peatlands by collectively using peatland development to reconstruct past climates concentrating on CVNWR. Radiocarbon dates obtained from Allegheny Mountains peatlands and trends in peat accumulation were interpreted in the context of published regional glacial chronology, paleoclimate, and paleoenvironmental literature.

During the Heinrich Stadial 2: 26,000 to 23,600 cal yr BP, glaciers advanced into Ohio and Pennsylvania (Heath et al., 2018) within 170 to $320 \mathrm{~km}$ from Allegheny Mountain peatlands in West Virginia and Maryland. Periglacial landforms caused by intense freeze-thaw activity and mass wasting occurred throughout higher elevations of the Appalachian Mountains, including the Allegheny Mountain physiographic section during the LGM (Braun, 1989; Clark and Ciolkosz, 1988; French and Millar, 2014; Ingham, 1996; Nelson et al., 2007; Whitehead, 1965). Open boreal woodlands and tundra were present along the ice margin north of $34^{\circ} \mathrm{N}$, with alpine tundra in the high elevations of the Appalachian Plateau (Delcourt and Delcourt, 1986; Jackson et al., 2000; Whitehead, 1973). Boreal cool-temperature conifers dominated vegetation south of the glacial limit to $33^{\circ} \mathrm{N}$ (Jackson et al., 2000; Whitehead, 1965, 1967, 1973; Yann et 
al., 2013). The mid-Atlantic region had forests ranging from cold temperate mixed coniferhardwood to high boreal in character (Litwin et al., 2013). Sirkin (1977) found tundra vegetation was prevalent throughout the Delmarva Peninsula until 18,000 cal yr BP. Leigh (2008) found that cold and dry conditions with savanna vegetation existed in the southeastern United States coastal plain from 30,000 to $16,000 \mathrm{cal}$ yr BP. High fire activity in central Tennessee coincided with the dominance of cool-temperature conifers from the Last Glacial Maximum (LGM) until 15,000 cal yr BP (Ballard et al., 2016).

As permafrost in the Allegheny Mountain section began to melt from 20,000 to 18,000 cal yr BP (French and Millar, 2014), tundra and alpine tundra vegetation retreated north and the colluvial geomorphic regime that dominated the tundra transitioned into a fluvial geomorphic regime (Delcourt and Delcourt, 1986). Basal peat dates from CVNWR, including 18,700 and $\sim 18,200$ cal yr BP (Table 2-3), are the oldest published dates for peat initiation in the Allegheny Mountain section. CVNWR cores revealed no transitional interbedded organic and mineral sediments indicative of wetland phase. Larabee (1986) dated a sediment sequence interpreted as evidence that Big Run Bog began as an open body of water that transitioned first into a wetland and subsequently later evolved into a peatland (Table 2-1). Maxwell and Davis (1972) dated mineral limnic sediments underlying peat at Buckles Bog, followed by clayey gyttja (Table 2-1) also interpreted as evidence of open water that transitioned into a wetland. As a result of immature and transitioning integrated drainages (Halsey et al., 2000) and an increase in available water (Morris et al., 2018), the landscape was stabilizing and favored the initiation of peatland development during 20,000 to 18,000 cal yr BP.

The climate of the northeastern United States and the Appalachian region ameliorated to warmer conditions around 14,000 cal yr BP (Delcourt and Delcourt, 1986; Kneller and Peteet, 
1993), roughly coinciding with the warm and moist Bølling-Allerød interstadial, from 14,500 to 12,600 cal yr BP (Williams et al., 2011; Yu, 2007). The warming and moistening climatic trend correlates with moderately high peat accumulation rates in CVNWR from $\sim 15,800$ to $\sim 12,500$ cal yr BP. Both Larabee (1986) at Big Run Bog and Maxwell and Davis (1972) at Buckles Bog show not only peat initiation, but also the most rapid peat accumulation during this interval. Watts (1979) dated organic clay from Cranberry Glades 14,100 cal yr BP (Table 2-1), as this ecosystem transitioned into a wetland. Halsey et al. (2000) identified that the majority of peat accumulation in central Appalachians occurred during this time interval.

The Bølling-Allerød interstadial was followed by the Younger Dryas stadial, a cold period from 12,600 to 11,700 cal yr BP (Miller and Gingerich, 2013; Webb et al., 1993; Williams et al., 2011). The Younger Dryas saw significant vegetation changes throughout the eastern United States (Shuman et al., 2002). Webb et al. (1993), studying pollen assemblages in the northeastern United States, concluded that the low annual precipitation, but high soil moisture around 12,000 cal yr BP, suggested cold temperatures correlating with the Younger Dryas. Radiocarbon dating at CVNWR, may not have been at a fine-enough resolution to detect the Younger Dryas; peat ages in CVNWR Core 3.13 from 12,960 to 11,687 cal yr BP show a very low accumulation rate of $0.06 \mathrm{~mm} / \mathrm{yr}$ (Table 2-3). Larabee (1986) and Maxwell and Davis (1972) both report fibrous organic clay $\sim 12,600 \mathrm{cal}$ yr BP, and fibrous peat $\sim 12,400$ cal yr BP, respectively, dating to this period (Table 2-1). It is unclear if Younger Dryas cold temperatures affected peatland development, as moisture balance is more essential than temperature in peat accumulation (Evans and Warburton, 2010; Loisel and Garneau, 2010; Vitt, 2006).

The Holocene Epoch, which began 11,700 cal yr BP, is an interglacial period with numerous smaller climatic fluctuations (Hou et al., 2011; Li et al., 2007; Webb III et al., 1998; 
Willard et al., 2005). The early Holocene Greenlandian Age, defined as 11,700 to 8,236 cal yr BP (Cohen et al., 2013; Head and Gibbard, 2015; Walker et al., 2012, 2018), was characterized in the eastern United States as a cool and dry period (Stinchcomb et al., 2012; Zhao et al., 2010) with an available moisture at a postglacial minimum around 9,000 cal yr BP (Li et al., 2007; Stinchcomb et al., 2012, 2013; Webb et al., 1993; Willard et al., 2005). The Greenlandian Age closely correlates with modest peat accumulation rates in CVNWR from $\sim 11,600$ to $\sim 8,600$ cal yr BP. Kneller and Peteet (1993), at Brown's Pond, Virginia, found low water levels indicating dryer conditions between 10,000 and 8,000 cal yr BP. The end of Greenlandian Age was marked by a pronounced millennial scale cold event at 8,236 cal yr BP (Daley et al., 2016; Head and Gibbard, 2015; Hu et al., 1999; Mayewski et al., 2004; Viau et al., 2006; Walker et al., 2012, 2018; Wanner et al., 2015; Willard et al., 2005).

The mid-Holocene Northgrippian Age, defined as 8,236 to 4,250 cal yr BP (Cohen et al., 2013; Head and Gibbard, 2015; Walker et al., 2012, 2018), was characterized in eastern North America as a complex and dynamic climatic interval interposed with numerous regional droughts (Newby et al., 2014; Shuman and Marsicek, 2016; Stinchcomb et al., 2013; Viau et al., 2006), including a drought 5,500 cal yr BP that coincided with a widespread Tsuga canadensis decline (Booth et al., 2012; Delcourt and Delcourt, 1986; Williams et al., 2011; Zhao et al., 2010). Eastern North America generally experienced a rise in temperature culminating with midHolocene Climatic Optimum, during which temperatures were considerably warmer than today (Beget, 1983; Driese et al., 2005; Fairbridge, 1982; Mullins et al., 2011; Springer et al., 2009; Wanner et al., 2015). The exact timing of the Climatic Optimum varied from region to region as did the coinciding abundance of available moisture (Barber et al., 1999; Clarke et al., 2003; Shuman and Marsicek, 2016; Viau et al., 2006; Zhao et al., 2010). 
Extremely low accumulation rates from CVNWR are consistent with very dry midHolocene climatic conditions. Research in central New York and eastern Lake Ontario indicate the overall-climate during the Climatic Optimum was generally warm and wet (McFadden et al., 2005; Mullins et al., 2011), whereas studies in eastern Pennsylvania, North Carolina, and Tennessee suggest warm and dry conditions (Ballard et al., 2016; Driese et al., 2008; Stinchcomb et al., 2013; Tanner et al., 2015). Webb at al. (1993) found slight increases in soil moisture and precipitation at 6,000 cal yr BP in the northeastern United States.

The Climatic Optimum in the central Appalachians has been identified in the central Appalachians. Watts (1979) found that late Quaternary vegetation of the central Appalachians indicated Climatic Optimum water tables were lower or less stable than today. Springer et al. (2009) found evidence of a warm Climatic Optimum in southeastern West Virginia while investigating stable isotopes in stalagmites and clastic cave sediments. Also working in southeastern West Virginia, Driese et al. (2005) found mid-Holocene warmer, dryer, climatic conditions weathered previously deposited fluvial gravel deposits. Cameron (1970) in Canaan Valley, Larabee (1986) in Big Run Bog, and Watts (1979) in Cranberry Glades all have recorded dates from this period; however, their dating resolution is not fine enough to determine accumulation rates and their varied soil profile descriptions did not follow soil science terminology to allow exact correlation. The Northgrippian Age ended with a pronounced climatic event at 4,250 cal yr BP which manifested in the mid-continent of North America as a widespread and severe drought (Booth et al., 2005; Shuman and Marsicek, 2016; Walker et al., 2012, 2018; Williams et al., 2011).

The late Holocene Meghalayan Age, from 4,250 cal yr BP to present (Head and Gibbard, 2015; Walker et al., 2012, 2018) brought wet conditions to the eastern United States (Willard et 
al., 2005), with minor climatic fluctuations including intermittent droughts, the Medieval Warming Period, and the Little Ice Age (Li et al., 2007; Newby et al., 2014; Shuman and Marsicek, 2016; Stinchcomb et al., 2013; Willard et al., 2005). Age-depth plots and the accumulation rates at CVNWR show rapid peat accumulation in the early Meghalayan Age, concurring with wet conditions. However, peat accumulation slowed in the late Meghalayan Age of CVNWR. Cameron's (1970) one radiocarbon date from CVNWR indicates an accumulation rate of $0.22 \mathrm{~mm} / \mathrm{yr}$ for the late Holocene. Booth et al. (2016) working on a single core in Cranesville Swamp dated peat accumulation beginning at $\sim 1,000$ cal yr BP. Larabee (1986) in Big Run Bog dated fibrous organic clay from the late Meghalayan Age. Although coarsely dated, overall Meghalayan Age, Allegheny Mountain peatland records do conform to the generally wet conditions for eastern United States regional paleoclimate reported by others.

\section{Conclusions}

Understanding peatland stratigraphy and development history is crucial to paleoclimatic reconstruction (Ovenden, 1990; Zhang et al., 2016). Extensive fieldwork coupled with highresolution dating of peat stratigraphy provides the thorough baseline necessary for an understanding of variations and similarities among Allegheny Mountain peatlands. The quantity of complete soil profile descriptions as well as dated cores from CVNWR allows this ecosystem to inform peatland development history more fully than previous studies of peatlands in the region, particularly because previously published cores are very difficult to interpret with certainty because profile descriptions terminology varied greatly from study to study.

Paleoenvironments interpreted from any one of the soil cores in this study could be considerably different from an interpretation based upon a comprehensive integration of the compiled history of peat development (Ovenden, 1990; Zhang et al., 2016). 
Future peat research in the region should follow standard NRCS soil-profile description procedures and taxonomic classifications to ensure consistency of interpretation. Variable peat stratigraphy and peat accumulation rates require the analysis of multiple cores within wellconstrained peatlands to avoid paleoclimatic interpretations skewed from individual peat cores that may be atypical of peatland-wide stratigraphy and regional events (Ovenden, 1990; Zhang et al., 2016). 


\section{References}

Ammann, B., van Leeuwen, J. F. N., van der Knaap, P., Colombaroli, D., Tinner, W., Wright, H. E., Stefanova, V., 2013. The role of peat decomposition in patterned mires: a case study from the central Swiss Alps. Preslia, 85 (3), 317-332.

Arnold, J. R., Libby, W.F., 1951. Radiocarbon dates. Science, 113 (2927), 111-120.

Ballard, J.P., Horn, S.P., Li, Z.H., 2016. A 23,000-year microscopic charcoal record from Anderson Pond, Tennessee, USA. Palynology, 41 (2), 216-229.

Barber D. C., Dyke A., Hillaire-Marcel C., Jennings A. E., Andrews J. T., Kerwin M. W., Bilodeau G., McNeely R., Southon J., Morehead M.D., Gagnon J.M., 1999. Forcing of the cold event of 8,200 years ago by catastrophic drainage of Laurentide lakes. Nature 400 (6742), 344-348.

Barrington, D.S., Paris, C.A., 2007. Refugia and migration in the Quaternary history of the New England flora. Rhodora, 109 (940), 369-386.

Beget, J. E., 1983. Radiocarbon-dated evidence of worldwide early Holocene climate change. Geology, 11 (7), 389.

Bender, M. M., Baerreis, D. A., Bryson, R. A., 1979. University of Wisconsin radiocarbon dates XVI. Radiocarbon, 21 (1), 120-130.

Bender, M. M., Baerreis, D. A., Bryson, R. A., 1977. University of Wisconsin radiocarbon dates XIV. Radiocarbon, 19 (1), 127-137.

Blaauw, M., Bakker, R., Christen, J. A., Hall, V. A., Van Der Plicht, J., 2007. A Bayesian framework for age modeling of radiocarbon-dated peat deposits: Case studies from the Netherlands. Radiocarbon, 49 (2), 357-367.

Blaauw, M., Christen, J. A., 2011. Flexible paleoclimate age-depth models using an autoregressive gamma process. Bayesian Analysis, 6 (3), 457-474.

Booth, R.K., Jackson, S.T., Forman, S.L., Kutzbach, J.E., Bettis III, E.A., Kreig, J., Wright, D.K., 2005. A severe centennial-scale drought in mid-continental North America 4200 years ago and apparent global linkages. The Holocene, 15 (3), 321-328.

Booth, R.K., 2010. Testing the climate sensitivity of peat-based paleoclimate reconstructions in mid-continental North America. Quaternary Science Reviews, 29 (5-6), 720-731. 
Booth, R.K., Brewer, S., Blaauw, M., Minckley, T.A., Jackson, S.T., 2012. Decomposing the mid-Holocene Tsuga decline in eastern North America. Ecology, 93 (8), 1841-1852.

Booth, R.K., Ireland, A.W., LeBoeuf, K., Hessl, A., 2016. Late Holocene climate-induced forest transformation and peatland establishment in the central Appalachians. Quaternary Research, 85 (2), 204-210.

Borren, W., Bleuten, W., Lapshina, E. D., 2004. Holocene peat and carbon accumulation rates in the southern taiga of western Siberia. Quaternary Research, 61 (1), 42-51.

Braun, D. D., 1989. Glacial and periglacial erosion of the Appalachians. Geomorphology, 2 (1), 233-256.

Bronk Ramsey, C., 2009. Bayesian analysis of radiocarbon dates. Radiocarbon, 51 (1), 337 360.

Byers, E. A., Vanderhorst, J. P., Streets, B. P., 2007. Classification and conservation assessment of high elevation wetland communities in the Allegheny Mountains of West Virginia. West Virginia Natural Heritage Program, WV Division of Natural Resources, Wildlife Resources Section, Elkins, West Virginia, 547 p.

Cameron, C. C., 1968. Peat, in Mineral resources in the Appalachian region. U.S. Geological Survey Professional Paper 580, 136-145.

Cameron, C. C., 1970. Peat resources of the unglaciated uplands along the Allegheny structural front in West Virginia, Maryland, and Pennsylvania. Geologic Survey Research 1970, Chapter D: U.S. Geological Survey Professional Paper 700-D, 153-161.

Carlisle, S.C, Mount, H.R., Brown, J.H., 1998. The mechanics of soil survey. Natural Resource Conservation Service, U.S. Department of Agriculture. Lincoln, Nebraska, 38 p.

Clark M. G., Ciolkosz, E. J., 1988. Periglacial geomorphology of the Appalachian highlands and interior highlands south of the glacial border - A review. Geomorphology, 1 (3), 191-220.

Clarke, G. K. C., Leverington, D. W., Teller, J. T., Dyke, A. S., 2003. Superlakes, megafloods, and abrupt climate change. Science, 301 (5635), 922-923.

Clymo, R. S., 1984. The limits to peat bog growth. Philosophical Transactions of the Royal Society of London. Series B, Biological Sciences, 303 (1117), 605-654.

Cohen, K.M., Finney, S.C., Gibbard, P.L., Fan, J.-X., 2013; updated. The ICS International Chronostratigraphic Chart. Episodes 36, 199-204. 
Cox, D. D., 1968. A late-glacial pollen record from the West Virginia-Maryland border. Castanea, 33 (2), 137-149.

Crann, C.A., Patterson, R.T., Macumber, A.L., Galloway, J.M., Roe, H.M., Blaauw, M., Swindles, G.T., Falck, H., 2015. Sediment accumulation rates in subarctic lakes: insights into age-depth modeling from 22 dated lake records from the Northwest Territories, Canada. Quaternary Geochronology, 27, 131-144.

Darlington H. C., 1943. Vegetation and substrate of Cranberry Glades. West Virginia. Botanical Gazette, 104 (3), 371-393.

Daley, T.J., Barber, K.E., Hughes, P.D.M., Loader, N.J., Leuenberger, M., Street-Perrott, F.A., 2016. The 8.2-ka BP event in north-eastern North America: first combined oxygen and hydrogen isotopic data from peat in Newfoundland. Journal of Quaternary Science, 3 (4), 416425.

Davis, E. N., Taylor, S. B., Kite, J. S., and Fedorko, N., 1999. Paleoperiglacial features and organic deposits in the Canaan Valley area. A field trip guide for the 12 June 1999 meeting of the West Virginia association of Professional Soil Scientists, 16p.

Davis, J. C., Proctor, I. D., Southon, J. R., Caffee, M. W., Heikkinen, D. W., Roberts, M. L., Moore, T. L., Turteltaub, K. W., Nelson, D. E., Loyd, D. H., Vogel, J. S., 1990. LLNL/US AMS facility and research program. Nuclear Instruments and Methods, section B, 52, 269-272.

Delcourt, H., Delcourt, P., 1986. Late Quaternary vegetational history in the central Atlantic States, in McDonald, J. N., and Bird, S. O., editors, The Quaternary of Virginia - a Proceedings Volume: Virginia Division of Mineral Resources Publication 75, 23-35.

Diehl, J. W., Behling, R. E., 1982. Geologic factors affecting formation and presence of wetlands in the north central section of the Appalachian Plateaus Province of West Virginia, in Proceedings of the Symposium on Wetlands of the Unglaciated Appalachian Region, West Virginia University, 20-26.

Driese, S. G., Li, Z., Horn, S. P., 2005. Late Pleistocene and Holocene climate and geomorphic histories as interpreted from a $23,000{ }^{14} \mathrm{C}$ yr B.P. paleosol and floodplain soils, southeastern West Virginia, USA. Quaternary Research, 63 (2), 136-149.

Driese, S.G., Li, Z.H., McKay, L.D., 2008. Evidence for multiple, episodic, mid-Holocene Hypsithermal recorded in two soil profiles along an alluvial floodplain catena, southeastern Tennessee, USA. Quaternary Research, 69 (2), 276-291.

Edens, D. L., 1973. The ecology and succession of Cranberry Glades, West Virginia. Raleigh, NC: North Carolina State University, Ph.D. dissertation. 
Evans, M.G., Warburton, J., 2010. Peatland geomorphology and carbon cycling. Geography Compass, 4 (10): 1513-31.

Fairbridge R.W., 1982. Hypsithermal. In: Beaches and Coastal Geology. Encyclopedia of Earth Science. Springer, Boston, MA.

Fenneman, N.M., Johnson, D.W., 1946. Physiographic Divisions of the United States. U.S. Geological Survey, Washington D.C.

Fedorko, Nick, 1993, Geology and pedology of a peat mire in Canaan Valley, West Virginia, unpublished Geology 329 term paper submitted to J.S. Kite, Morgantown, WV, Department of Geology and Geography, West Virginia University, 28 p.

Fortney, R. H., Rentch, J. S., 2003. Post logging era plant successional trends and geospatial vegetation patterns in Canaan Valley, West Virginia, 1945 to 2000. Castanea, 68 (4), 317-334.

Francl, K. E., Ford, W. M., Castleberry, S. B., 2004. Characterization of high elevation central Appalachian wetlands. Research Paper NE-725. USDA Forest Service, Northeastern Research Station, Newtown Square, PA, 26 p.

French, H. M., Millar, S. W. S., 2014. Permafrost at the time of the Last Glacial Maximum (LGM) in North America. Boreas, 43 (3), 667-677.

Givelet, N., Le Roux, G., Cheburkin, A., Chen, B., Frank, J., Goodsite, M.E., Kempter, H., Krachler, M., Nørnberg, T., Rausch, N., Rheinberger, S., Roos-Barraclough, F., Sapkota, A., Scholz, C., Shotyk, W., 2004. Suggested protocol for collecting, handling and preparing peat cores and peat samples for physical, chemical, mineralogical and isotopic analyses. Journal of Environmental Monitoring, 6 (4), 1464-0325.

Halsey, L A., Vitt, D. H., Gignac, L. D., 2000. Sphagnum-dominated peatlands in North America since the Last Glacial Maximum: their occurrence and extent. The Bryologist, 103 (2), 334-352.

Head, M.J., Gibbard, P.L., 2015. Formal subdivisions of the Quaternary System/Period: Past, present, and future. Quaternary International, 383, 4-35.

Heath, S.L, Loope, H.M., Curry, B.B., Lowell, T.V., 2018. Pattern of southern Laurentide Ice Sheet margin position changes during Heinrich Stadials 2 and 1. Quaternary Science Reviews, 201, 362-379.

Holden, J., 2005. Peatland hydrology and carbon release: why small-scale process matters. Philosophical Transactions of the Royal Society A, Mathematical, Physical and Engineering Sciences, 363 (1837), 2891-2913. 
Hou, J., Huang, Y., Shuman, B.N., Oswald, W.W., Foster, D.R., 2011. Abrupt cooling repeatedly punctuated early-Holocene climate in eastern North America. The Holocene, 22 (5), 525-529.

Hu, F. S., Slawinski, D., Wright Jr., H.E., Ito, E., Johnson, R. G., Kelts, K. R., McEwan, R.F., Boedigheimer, A., 1999. Abrupt changes in North American climate during early Holocene times. Nature, 400 (6743), 437-440.

Ingham, M. E., 1996. The bog region of the Allegheny Mountains of West Virginia. Tampa, Florida: University of South Florida. M.A. thesis, 172 p.

Jackson, S.T., Webb, R.S., Anderson, K.H., Overpeck, J. T., Webb III, T., Williams, J. W., Hansen, B., 2000. Vegetation and environment in Eastern North America during the Last Glacial Maximum. Quaternary Science Reviews, 19 (6), 489-508.

Kneller, M., Peteet, D., 1993. Late-Quaternary climate in the Ridge and Valley of Virginia, U.S.A.: Changes in vegetation and depositional environment: A contribution to the 'North Atlantic seaboard programme' of IGCP-253, 'Termination of the Pleistocene', Quaternary Science Reviews, 12 (8), 613-628.

Kost, M.A., Albert, D.A., Cohen, J.G., Slaughter, B.S., Schillo, R.K., Weber, C.R., Chapman, K.A., 2007. Natural communities of Michigan: classification and description. Michigan Natural Features Inventory, Report No. 2007-21, Lansing, MI.

Larabee, P.A., 1986. Late-Quaternary vegetational and geomorphic history of the Allegheny Plateau at Big Run Bog, Tucker County, West Virginia. The University of Tennessee, Knoxville. M.S. thesis, 116 p.

Leigh, D.S., 2008. Late Quaternary climates and river channels of the Atlantic Coastal Plain, Southeastern USA. Geomorphology, 101 (1-2), 90-108.

Li, Y., Yu, Z., Kodama, K.P., 2007. Sensitive moisture response to Holocene millennial-scale climate variations in the mid-Atlantic region, USA. The Holocene, 17 (1), 3-8.

Litwin, R.J., Smoot, J.P., Pavich, M.J., Markewich, H.W., Brook, G., Durika, N.J., 2013. 100,000-year-long terrestrial record of millennial-scale linkage between eastern North American mid-latitude paleovegetation shifts and Greenland ice-core oxygen isotope trends. Quaternary Research, 80 (2), 291-315.

Loisel, J., Garneau, M., 2010. Late Holocene paleoecohydrology and carbon accumulation estimates from two boreal peat bogs in eastern Canada: Potential and limits of multi-proxy archives. Palaeogeography, Palaeoclimatology, Palaeoecology 291, 493-533. 
Losche, C.K., Beverage, W.W., 1967. Soil Survey of Tucker County and part of northern Randolph County, West Virginia: Washington, D.C., U.S. Soil Conservation Service, 78 p.

Martin, J., Germain, D., 2016. Late-glacial and Holocene evolution as a driver of diversity and complexity of the northeastern North American alpine landscapes: a synthesis. Canadian Journal of Earth Science, 53 (5), 494-505.

Matchen, D.L., Fedorko, N., Blake, Jr., B.M., 1999. Geology of Canaan Valley, West Virginia Geological and Economic Survey Open File Publication, OF-9902.

Matchen, D. L., 2015. The geology of Canaan Valley. Southeastern Naturalist, 14 (7), 7-17.

Maxwell, J. A., Davis, M. B., 1972. Pollen evidence of Pleistocene and Holocene vegetation on the Allegheny Plateau, Maryland. Quaternary Research, 2 (4), 506-530.

Mayewski, P., Rohling, E., Stager, J., Karlen, W., Maasch, K., Meeker, L., Meyerson, E., Gasse, F., van Kreveld, S., Holmgren, K., Lee-Thorp, J., Rosqvist, G., Rack, F., Staubwasser, M., Schneider, R., Steig, E., 2004. Holocene climate variability. Quaternary Research, 62 (3), 243 255.

McFadden, M.A., Patterson, W.P. Mullins, H.T., Anderson, W.T., 2005. Multi-proxy approach to long and short-term Holocene climate change: evidence from eastern Ontario. Journal of Paleolimnology, 33 (3), 371-391.

Miller, D.S., Gingerich, J.A.M., 2013. Regional variation in the terminal Pleistocene and early Holocene radiocarbon record of eastern North America. Quaternary Research, 79 (2), 175-188.

Morris, P., Swindles, P., Valdes, P., Ivanovic, R., Gregoire, L., Smith, M., Tarasov, L., Haywood, A., Bacon, K., 2018. Global peatland initiation driven by regionally asynchronous warming. Proceedings of the National Academy of Sciences, 115 (19), 4851-4856.

Mullins, H.T., Patterson, W.P., Teece, M.A., Burnett, A.W., 2011. Holocene climate and environmental change in central New York. Journal of Paleolimnology, 45 (2), 243-256.

Nelson, K. J., Park, N., Frederick E., Walegur, M. T., 2007. Periglacial Appalachia: palaeoclimatic significance of blockfield elevation gradients, eastern USA. Permafrost and Periglacial Processes, 18 (1), 61-73.

Newby, P.E., Shuman, B.N., Donnelly, J.P., Karnauskas, K.B., Marsicek, J., 2014. Centennialto-millennial hydrologic trends and variability along the North Atlantic Coast, USA, during the Holocene. Geophysical Research Letters, 41 (12), 4300-4307. 
Ovenden, L., 1990. Peat accumulation in Northern Wetlands. Quaternary Research, 33 (3), 377 386.

Phillips, S. W., 1925, Soil survey of Tucker County, West Virginia: Washington, D.C., U.S. Govt. Printing Office, p. 1329-1365.

Piotrowska, N., Blaauw, M., Mauquoy, D., Chambers, F.M., 2010. Constructing deposition chronologies for peat deposits using radiocarbon dating. Mires and Peat, 7 (10), 1-14.

Reger, J., Cleaves, E., 2008. Physiographic map of Maryland. Maryland Geological Survey, Baltimore, Maryland.

Reimer, P. J., Bard, E., Bayliss, A., Beck, J. W., Blackwell, P. G., Bronk Ramsey, C., Grootes, P. M., Guilderson, T. P., Haflidason, H., Hajdas, I., HattŽ, C., Heaton, T. J., Hoffmann, D. L., Hogg, A. G., Hughen, K. A., Kaiser, K. F., Kromer, B., Manning, S. W., Niu, M., Reimer, R. W., Richards, D. A., Scott, E. M., Southon, J. R., Staff, R. A., Turney, C. S. M., van der Plicht, J., 2013. IntCal13 and Marine13 radiocarbon age calibration curves 0-50,000 years cal BP. Radiocarbon, 55 (4), 1869-1887.

Rigg, G. B., Strausbaugh, P. D., 1949. Some stages in the development of sphagnum bogs in West Virginia. Castanea, 14 (4), 129-148.

Russell, D. A., Rich, F. J., Schneider, V., Lynch-Stieglitz, J, 2009. A warm thermal enclave in the late Pleistocene of the south-eastern United States. Biological Reviews, 84 (2), 173-202.

Sencindiver, J., Thomas, K., Teets, J., 2015. Soils of Canaan Valley and adjacent mountains. Southeastern Naturalist, 14 (7), 33-39.

Sevon, W., 2018. Physiographic provinces of Pennsylvania. Commonwealth of Pennsylvania Department of Conservation and Natural Resources, Bureau of Topographic and Geologic Survey, Harrisburg, Pennsylvania.

Shuman, B., Webb III, T., Bartlein, P., Williams, J. W., 2002. The anatomy of a climatic oscillation: vegetation change in eastern North America during the Younger Dryas chronozone. Quaternary Science Reviews, 21 (16-17), 1777-1791.

Shuman, B.N., Marsicek, J., 2016. The structure of Holocene climate change in mid-latitude North America. Quaternary Science Reviews, 141, 38-51.

Sirkin, L., 1977. Late Pleistocene vegetation and environments in the middle Atlantic region. NYAS Annals of the New York Academy of Sciences, 288 (1), 206-217. 
Soil Survey Staff, 1999. Soil Taxonomy: A basic system of soil classification for making and interpreting soil surveys. 2nd edition. Natural Resources Conservation Service. U.S. Department of Agriculture Handbook, 436 p.

Springer, G.S., Rowe, H.D., Hardt, B., Cocina, F.G., Edwards, R. L., Cheng, H., 2009. Climate driven changes in river channel morphology and base level during the Holocene and late Pleistocene of southeastern West Virginia. Journal of Cave and Karst Studies, 71 (2), 121-129.

Stinchcomb, G.E., Driese, S.G., Nordt, L.C., Allen, P.M., 2012. A mid to late Holocene history of floodplain and terrace reworking along the middle Delaware River valley, USA. Geomorphology, 169-170, 123-141.

Stinchcomb, G.E., Messner, T.C., Williamson, F.C., Driese, S.G., Nordt, L.C., 2013. Climatic and human controls on Holocene floodplain vegetation changes in eastern Pennsylvania based on the isotopic composition of soil organic matter. Quaternary Research, 79 (3), 377-390.

Stine, M. B., Resler, L. M., Campbell, J. B., 2011. Ecotone characteristics of a southern Appalachian Mountain wetland. Catena, 86 (1), 57-65.

Stivrins, N., Ozola, I., Galka, M., Kuske, E., Alliksaar, T., Andersen, T.J., Lamentowicz, Wulf, S., Reitalu, T., 2017. Drivers of peat accumulation rate in a raised bog: impact of drainage, climate, and local vegetation composition. Mires and Peat, 19 (8), 1-19.

Stuiver M., Polach H.A., 1977. Discussion: reporting of 14C data. Radiocarbon, 19 (3), 355363.

Tanner, B. R., Lane, C. S., Martin, E. M., Young, R., Collins, B., 2015. Sedimentary proxy evidence of a mid-Holocene Hypsithermal event in the location of a current warming hole, North Carolina, USA. Quaternary Research, 83 (2), 315-323.

Tuittila, E., Juutinen, S. Frolking, S., Väliranta, M., Laine, A. M., Miettinen, A., Seväkivi, M., Quillet, A., Merilä, P., 2013. Wetland chronosequence as a model of peatland development: Vegetation succession, peat and carbon accumulation. The Holocene, 23 (1), 25-35.

Viau, A.E., Gajewski, K., Sawada, M.C., Fines, P., 2006. Millennial-scale temperature variations in North America during the Holocene. Journal of Geophysical Research, 111 (D9).

Vitt, D. H., 2006. Bryophyte Community Ecology: Going Beyond Description. Lindbergia, 31 (1), 33-41.

Vogel, J.S., Southon, J. R., Nelson, D. E., 1987. Catalyst and binder effects in the use of filamentous graphite for AMS. Nuclear Instruments and Methods, section B., 29, 50-56. 
Walbridge, M. R., 1994. Plant community composition and surface water chemistry of fen peatlands in West Virginia's Appalachian plateau. Water, Air, and Soil Pollution, 77 (3-4), 247269.

Walker, M.J.C., Berkelhammer, M., Björck, S., Cwynar, L.C., Fisher, D.A., Long, A.J., Lowe, J.J., Newnham, R.M., Rasmussen, S.O., Weiss, H., 2012. Formal subdivision of the Holocene Series/Epoch: a discussion paper by a Working Group of INTIMATE (Integration of ice-core marine and terrestrial records) and the Subcommission on Quaternary Stratigraphy (International Commission on Stratigraphy). Journal of Quaternary Science, 27 (7), 649-659.

Walker, M., Head, M.J., Berkelhammer, M., Björck, S., Cheng, H., Cwynar, L., Fisher, D., Gkinis, V., Long, A., Lowe, J., Newnham, R., Rasmussen, S.O., Weiss, H., 2018. Formal ratification of the subdivision of the Holocne Series/Epoch (Quaternary System/Period): two new Global Boundary Stratotype Sections and Points (GSSPs) and three new stages/subseries. Episodes, 41 (4), 213-223.

Wanner, H., Mercolli, L., Grosjean, M., Ritz, S.P., 2015. Holocene climate variability and change; a data-based review. Journal of the Geological Society, 172 (2), 254-263.

Watts, W. A., 1979. Late Quaternary vegetation of central Appalachia and the New Jersey coastal plain. Ecological Monographs, 49 (4), 427-469.

Webb, R. S., Anderson, K. H., Webb III, T., 1993. Pollen response-surface estimates of lateQuaternary changes in the moisture balance of the northeastern United States. Quaternary Research, 40 (2), 213-227.

Webb III, T., Anderson, K. H., Bartlein, P.J., Webb, R. S., 1998. Late Quaternary climate change in eastern North America: a comparison of pollen-derived estimates with climate model results. Quaternary Science Reviews, 17 (6-7), 587-606.

West Virginia Geologic and Economic Survey, 2017. Physiographic provinces of West Virginia. West Virginia Geologic and Economic Survey, Morgantown, West Virginia.

Western Regional Climate Center, 2016. Canaan Valley, West Virginia (461393), Period of Record Monthly Climate Summary. Retrieved from http://www.wrcc.dri.edu/cgibin/cliMAIN.pl?wv1393.

Whitehead, D. R., 1965. Palynology and Pleistocene phytogeography of unglaciated eastern United States, in Wright, H. E. Jr., Frey, D. G., editors The Quaternary of the United States: Princeton University Press, 417-432. 
Whitehead, D. R., 1967. Studies of full-glacial vegetation and climate in southeastern United States, 237-248, in Cushing, E.J., Wright, H.E., Jr., editors Quaternary Paleoecology: New Haven, Yale University Press.

Whitehead, D. R., 1973. Late-Wisconsin vegetational changes in unglaciated eastern North America. Quaternary Research, 3 (4), 621-631.

Wieder, R. K., McCormick, A. M., Lang, G. E., 1981. Vegetational analysis of Big Run Bog, a nonglaciated sphagnum bog in West Virginia. Castanea, 46 (1), 16-29.

Williams, J.W., Blois, J.L., Shuman, B.N., 2011. Extrinsic and intrinsic forcing of abrupt ecological change: case studies from the late Quaternary. Journal of Ecology, 99 (3), 664-677.

Willard, D., Bernhardt, C., Korejwo, D., Meyers, S., 2005. Impact of millennial-scale Holocene climate variability on eastern North American terrestrial ecosystems: pollen-based climatic reconstruction. Global and Planetary Change, 47 (1), 17-35.

Yann, L.T., DeSantis, L.R.G., Haupt, R.J., Romer, J.L., Corapi, S.E., Ettenson, D.J., 2013. The application of an oxygen isotope aridity index to terrestrial paleoenvironmental reconstructions in Pleistocene North America. Paleobiology, 39 (4), 576-590.

Yu, Z., 2007. Rapid response of forested vegetation to multiple climatic oscillations during the last deglaciation in the northeastern United States. Quaternary Research, 67 (2), 297-303.

Zhang, W., Yan, H., Cheng, P., Lu, F., Li, M., Dodson, J., Zhou, W., An, Z., 2016. Peatland development and climate changes in the Dajiuhu basin, central China, over the last 14,100 years. Quaternary International, 425, 273-281.

Zhao, C., Yu, Z., Ito, E.., Zhao Y., 2010. Holocene climate trend, variability, and shift documented by lacustrine stable-isotope record in the northeastern United States. Quaternary Science Reviews, 29 (15-16), 1831-1843. 


\title{
Chapter 3
}

\section{Evidence of mid-Holocene (Northgrippian Age) dry climate recorded in organic soil profiles in the central Appalachian Mountains.}

\author{
Mitzy L. Schaney ${ }^{\text {a, }}$, J. Steven Kite ${ }^{b}$, Christopher R. Schaney ${ }^{\text {c }}$, James A. Thompson ${ }^{d}$ \\ ${ }^{\text {a }}$ Geography Department, University of Pittsburgh at Johnstown, Krebs Hall 108D, 450 \\ Schoolhouse Road, Johnstown, PA 15904 \\ ${ }^{\mathrm{b}}$ Department of Geology and Geography, West Virginia University, 330 Brooks Hall, P.O. Box \\ 6300, Morgantown, WV 26506 \\ ${ }^{c}$ Department of Geography, Indiana University of Pennsylvania, 981 Grant Street, Indiana, PA \\ 15705 \\ ${ }^{\mathrm{d}}$ Division of Plant and Soil Science, West Virginia University, 3115 Agricultural Sciences \\ Building, 1194 Evansdale Drive, Morgantown, WV 26506-6108 \\ *Corresponding author: $\underline{\text { m.schaney@pitt.edu }}$
}

\begin{abstract}
Peatlands in Canaan Valley National Wildlife Refuge hold a pedomemory of latest Pleistocene and Holocene climatic fluctuations in the central Appalachian Mountains. A field investigation profiling 88 organic soil profiles, coupled with 52 radiocarbon dates and peat accumulation rates, revealed a distinct sequence of organic soil horizons throughout five study areas. The dominant anaerobic lower portions of the organic soil profiles consist of varied thicknesses of a combination of hemic and sapric soil materials, typically layered as an upper hemic horizon, underlain by a sapric horizon, underlain by another hemic horizon. Peat deposition began after the Last Glacial Maximum with relatively high Heinrich Stadial 1 accumulation rates to form the lowest hemic horizon. Peat accumulated at significantly slower rates as the climate continued to ameliorate in the early Holocene Greenlandian Age. However, between 10,000 and 4,200 cal yr BP peat accumulation decreased even further and
\end{abstract}


decomposition of previously deposited peat prevailed, forming the sapric, or most decomposed, horizon. This interval of greater decomposition indicates a climatic change to a dryer environment with dates spanning the late Greenlandian Age through the mid-Holocene Northgrippian Age. The upper hemic horizon within the anaerobic portion of the soil profile formed from high peat accumulation rates during the wetter late Holocene Meghalayan Age. Very few samples were collected correlating to the last 2000 years of the late Meghalayan Age; however, those few do indicate a decreased peat accumulation rates.

\section{Introduction}

The Laurentide Ice Sheet advanced within 170 to $320 \mathrm{~km}$ from Allegheny Mountain peatlands in West Virginia and Maryland during the Heinrich Stadial 2, 26,000 to 23,600 cal yr BP (Clark and Ciolkosz, 1988; Lowell et al., 1990; Jackson et al., 2000; Heath et al., 2018). A cold dry climate with alpine tundra occupied this periglacial region of the central Appalachian Mountains during the Last Glacial Maximum (LGM) (Delcourt and Delcourt, 1988; Nelson et al., 2007; French and Millar, 2014). The climate of the eastern United States, including the Appalachian region, ameliorated to warmer conditions after the LGM, near the end of the late Pleistocene (Delcourt and Delcourt, 1987; Kneller and Peteet, 1993; Yu, 2007). The Holocene Epoch, which began 11,700 cal yr BP, was an interglacial with numerous climatic fluctuations in eastern North America (Webb et al., 1993; Willard et al., 2005; Li et al., 2007; Hou et al., 2011). The early Holocene Greenlandian Age, defined as 11,700 to 8,236 cal yr BP (Walker et al., 2012; Cohen et al., 2013; Head and Gibbard, 2015; Walker et al., 2018), was characterized in the eastern United States as a cool and dry period that ended with a pronounced millennial scale cold event at 8,236 cal yr BP (Zhao et al., 2010; Stinchcomb et al., 2013; Head and Gibbard, 2015; Daley et al., 2016). The mid-Holocene Northgrippian Age, defined as 8,236 to $4,250 \mathrm{cal}$ yr BP 
(Walker et al., 2012; Cohen et al., 2013; Head and Gibbard, 2015; Walker et al., 2018), was characterized in eastern North America generally as a rise in temperature culminating with the mid-Holocene Climatic Optimum (Viau et al., 2006; Zhao et al., 2010; Shuman and Marsicek, 2016). The Northgrippian Age ended with a climatic event at 4,250 cal yr BP that manifested in the mid-continent of North America as a widespread and severe drought (Booth et al., 2005; Williams et al., 2011; Walker et al., 2012; Shuman and Marsicek, 2016; Walker et al., 2018). The late Holocene Meghalayan Age, from 4,250 cal yr BP to present (Walker et al., 2012; Head and Gibbard, 2015; Walker et al., 2018) brought wet conditions to the eastern United States (Willard et al., 2005).

Climate, primarily temperature and precipitation, is the principal allogenic forcing factor in peatland development over millennial timescales (Barber et al., 2003; Charman et al., 2009; Gao et al., 2010; Charman et al., 2015; Kalnina et al., 2015; Morris et al., 2018), with successional vegetation change a significant autogenic influence (Charman et al., 2015; Gałka et al., 2018). Peatlands form when net primary production of vegetation exceeds decomposition, resulting in accumulation of organic matter (Vitt, 2006). Peatland persistence requires a positive water balance for long-term growth and maintenance; positive water balance generally is favored by higher precipitation (Vitt, 2006; Evans and Warburton, 2010). Historically, wet climates tend to have greater peat growth rates (Tuittila et al., 2012). Woody peat and Sphagnum peat have relatively higher accumulations rates than peat derived from other vegetation types (Ovenden, 1990); Sphagnum and other bryophyte tissue decomposes more slowly than vascular plant litter and roots (Vitt et al., 2009).

Histosols are organic soils comprised of sapric, hemic, and fibric materials (Figure 3-1) and are primarily located within peatlands. The acrotelm is the aerobic upper portion of the soil 
profile and generally consists of less humified fibric soil material that has a lower bulk density. The acrotelm-catotelm boundary is approximately the mean depth of minimum water table during the growing season (Clymo, 1984) and is marked by highly humified sapric soil material. The anaerobic catotelm is the lower portion of the organic soil profile and generally consists of various thicknesses of a combination of hemic and sapric soil materials with higher bulk densities. Histosols are in equilibrium with their environment, such that disturbance to the water balance or vegetation community may result in a change in character of the constituent organic soil materials (Lee and Manoch, 1974; Gałka et al., 2018). A distinctive feature of Histosols is stratification resulting from accumulation of vegetation detritus under changing environmental conditions (Lee and Manoch, 1974). Barber (1981) showed a direct correlation of temperature and precipitation to peat stratigraphy, particularly peat humification and character of the peat. Identification of stratigraphic discontinuities in the degree of peat humification is a frequently utilized tool to assess past climatic and environmental conditions (Wieder et al., 2009). Peat decomposition and humification are a direct result of peatland surface wetness conditions (Lee and Manoch, 1974; Frolking et al., 2001; Gunnarson et al., 2003; Chambers et al., 2010; Kalnina et al., 2015). Peatland surface wetness relates to the depth from the surface of the water table. Peat decomposition is greater when the peatland surface is relatively dry, when water tables are lower than when the peatland surface is relatively wet (Castro et al., 2015). Surface wetness conditions are closely related to climatic fluctuations in precipitation and temperature, thus peat 
stratigraphy can act as a proxy climate record (Clymo, 1984; Blackford, 2000; Barber et al., 2003; Chambers et al., 2010; Langdon et al., 2012; Kalnina et al., 2015).

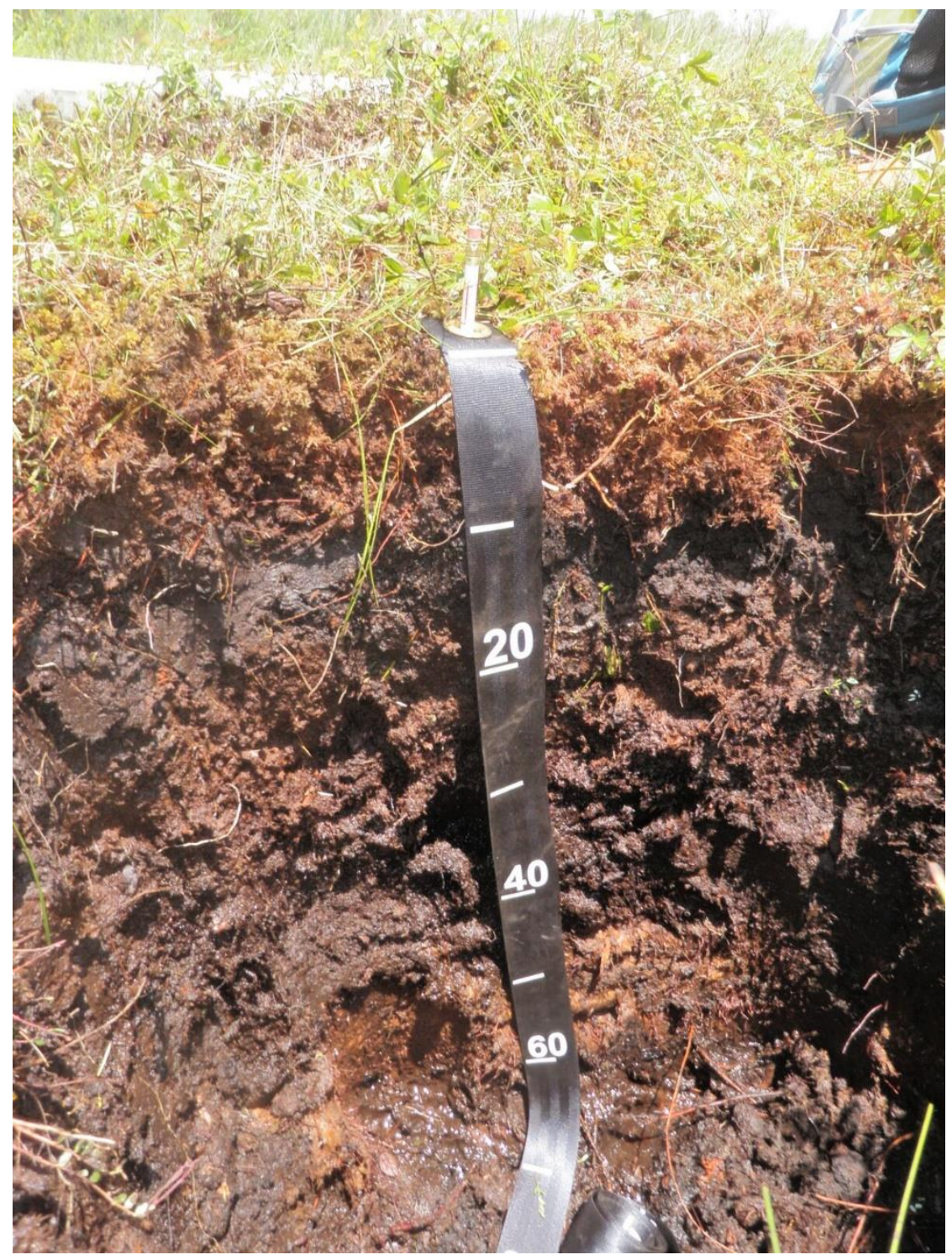

Figure 3-1. Example of a Histosol profile from Core 5.1.

Analysis of peat stratigraphy and the physical characteristics of the peat have shown that peatlands hold an in-situ record of their initiation and subsequent development (Vitt and Wieder, 2006). Pedomemory is both the capacity of a soil system to record environmental conditions 
through pedogenesis and the record that is retained within the soil profile (Targulian and Goryachkin, 2004; Lin, 2011; Nauman et al., 2015). Humification is one of the pedogenic processes that determines the pedomemory of peatland development and climatic conditions over time. Histosols may record climate-driven changes in stratigraphy in which dryer phases are represented by sapric soil material in dark well-humified horizons, and wetter phases are represented by hemic soil material in light less-humified horizons (Lee and Manoch, 1974; Frolking et al., 2001; Gunnarson et al., 2003; Kalnina et al., 2015).

Using peat stratigraphy, the objectives of this study are to expand and improve understanding of the paleoclimatic history of five peatlands in Canaan Valley National Wildlife Refuge (CVNWR) and to provide insights into the pedomemory of peatlands in the central Appalachian Mountains. Worldwide, peat stratigraphy has been utilized for over a century to study late Quaternary climate change, but despite the recognized value of peat humification analysis for paleoenvironmental reconstructions (Halsey et al., 2000; Castro et al., 2015), it has not been used in the central Appalachians. This study adds to existing regional and local peat paleoclimate observations with the characterization of Histosols and peat stratigraphy revealing the peatland surface wetness dynamics within CVNWR. With 100 soil cores profiled and described, including 30 with lab data, the abundance of observations within this investigation adds breadth to existing regional and local paleoclimate reconstructions. An understanding of past paleoclimate in these peatlands, including how they evolved and responded to climatic change, is valuable knowledge for interpreting how they might respond to projected future climate change. 


\section{Project area}

Peatlands commonly occur in boreal regions; however, high elevations along the Allegheny Mountains also sustain local boreal ecosystems (Wieder and Vitt, 2006). The Allegheny Mountain section of the central Appalachian Mountains (Fenneman and Johnson, 1946; Reger and Cleaves, 2008; Sevon, 2018; West Virginia Geologic and Economic Survey, 2017) includes geographic niches very similar climatically to more northern boreal peatlands, with high mean annual precipitation, low mean annual temperature, and low soil temperatures (Rigg and Strausbaugh, 1949; Cameron, 1970; Walbridge, 1994). Regional climatic conditions are intensified by orographic precipitation and local topographic frost pockets, where cold, dense nocturnal air drains downslope decreasing valley floor temperatures (Walbridge, 1994).

Allegheny Mountain peatlands range in size from a few hectares to a few hundred hectares (Ingham, 1996), and are typically situated at elevations above $730 \mathrm{~m}$ in the unglaciated plateau. Byers et al. (2007) placed Allegheny Mountain peatlands within the High Allegheny Wetland Ecological System, which occurs in a southwest-northeast trending $\sim 40 \mathrm{~km}$ wide by $\sim 200 \mathrm{~km}$ long band along the Allegheny Mountain section of the unglaciated Appalachian Plateaus physiographic province in Pennsylvania, Maryland, and West Virginia (Cameron, 1970). In general, the Allegheny Mountain section is higher in elevation than adjacent physiography and is characterized by broad, open structural bedrock folds.

Differential erosion has formed structurally controlled bedrock valleys and concave bottomlands of the Allegheny Mountains. Impeded drainage developed within these valleys before the Holocene (Cameron, 1970), most likely by the blockage of drainage by periglacial activity (Larabee, 1986). Allegheny Mountain peatlands occur in or near the headwaters of firstor second-order streams or occur in specific geologic niches (Rigg and Strausbaugh, 1949; 
Ingham, 1996). Canaan Valley, in Tucker County, West Virginia (Figure 3-2), is a highelevation $(980 \mathrm{~m})$, breached anticlinal valley, associated with the Blackwater anticline.

Headwaters of the Blackwater River, within the Cheat River watershed, drain most of the valley. Resistant Pottsville Sandstone caps the surrounding mountain ridges, with elevations over 1,250 m, Mauch Chunk Formation siltstones, shales, and immature sandstones form the more easily erodible valley slopes, and Greenbrier Limestone and lower Mauch Chunk siltstones and shales underlie most of the valley floor (Matchen et al., 1999; Fortney and Rentch, 2003; Matchen, 2015). Projecting up to $80 \mathrm{~m}$ above the valley floor is a low, elongated ridge comprised of coarse-grained sandstone of the Price Formation exposed along the axis of the anticline (Matchen, 2015).

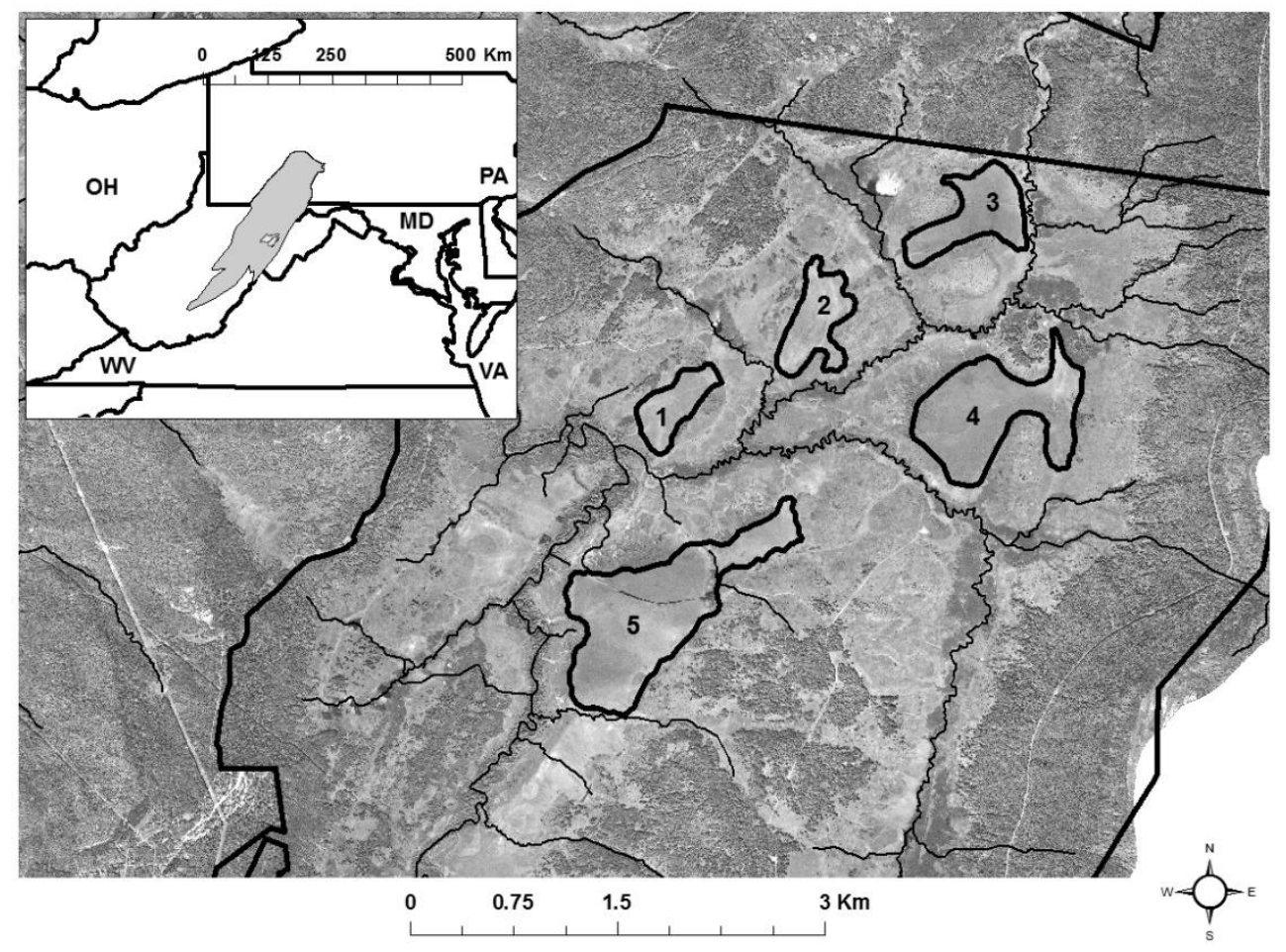

Figure 3- 2. Location of Canaan Valley National Wildlife Refuge boundary including Peatlands 1 through 5. Inset map displays CVNWR boundary within the Allegheny Mountain physiographic section (gray polygon). Aerial imagery obtained from the National Agriculture Inventory Program 2007 by United States Department of Agriculture. 
The floor of Canaan Valley contains one of the largest upland freshwater wetland ecosystems of peatlands, marshes, wet meadows, and shrub-forested wetlands in the eastern United States (Fortney and Rentch, 2003). These are flood- and beaver-influenced wetlands encompassing shrub swamps, sedge fens, wet meadows, and open marshes (Byers et al., 2007). Forested swamps occupy the slightly higher elevation around the peatland margins. CVNWR encompasses the northern portion of Canaan Valley, protecting most of West Virginia's largest wetland complex, including five remapped peatlands totaling 246 hectares (Figure 3-2). Smallunnamed tributaries of the Blackwater River, bordered by shallow Entisols with thin histic epipedons or hydric components separate these five peatlands. These minerotrophic peatlands are characterized by exceptionally high biodiversity and conservation value; they contain some of the highest concentrations of globally rare plant and animal species within the eastern United States (Byers et al., 2007). They have the largest peat deposits located in the unglaciated uplands along the Allegheny structural front in West Virginia, Maryland, and Pennsylvania (Cameron, 1970). They are ecologically classified as very poor fens: very acidic, moderately influenced by ground water, and dominated by sedges with a continuous carpet of Sphagnum (Kost et al., 2007). Bryophyte groundcover vegetation in these peatlands consists of Sphagnum rubellum, Sphagnum recurvum, Sphagnum palustre, Polytrichum commune. Herbaceous vegetation includes of Eriophorum virginicum (tawny cottongrass), Rhyncospora alba (white beaksedge), and minor amounts of Scirpus sp. (bulrush). Woody shrub vegetation commonly consists of Photinia melanocarpa (black chokeberry), Vaccinium oxycoccos (small cranberry), Vaccinium myrtilloides (velvetleaf blueberry), and Rubus hispidus (bristly dewberry). 


\section{Methodology}

Soil morphology is a record of past and current ecological and geomorphic processes (Daniels and Hammer, 1992); it can provide basic data for interpreting soil genesis (Buol et al., 1997), as well as insight into how ecosystems change (Nauman et al., 2015). Peat stratigraphy based upon soil morphologic descriptions, which are comprised of detailed soil profile descriptions and laboratory data, shed light upon the developmental and climatic history of peatlands (Yu et al., 2009).

$\underline{\text { Field methods }}$

Old Soil Conservation Service (SCS) map unit polygons, labeled as "muck and peat", provided an initial base map for this research. The SCS soil polygons were originally published in the Soil Survey of Tucker County (Losche and Beverage, 1967); the soil survey data were collected between 1959 and 1964, and mapped on 1956 and 1958 aerial photographs. The five muck and peat polygons were designated as Peatlands 1 through 5 for this study, which included re-mapping these polygons based on new data and updated imagery. Soil morphology was described (Schoeneberger et al., 2012) by profiling 100 soil cores throughout and around the five study areas, including 32 in Peatland 1, 11 in Peatland 2, 19 in Peatland 3, 21 in Peatland 4, and 17 in Peatland 5. Thirty of the 100 cores were sampled for laboratory analysis including radiocarbon dating, bulk density, total organic matter content, fiber content, and pyrophosphate color. Soil profiles were classified based upon the field descriptions and laboratory data, using U.S. Department of Agriculture, Natural Resources Conservation Service, Soil Taxonomy (Soil Survey Staff, 1999).

Soil core locations were chosen according to the "free survey" method of sampling soils, which involves the individual development and application of soil-landscape concepts based on 
the observation that soils vary repetitively and predictably with geomorphology, topography, and similar information (Carlisle et al., 1998). Locations of cores were representative of the immediately surrounding terrain. Small-scale hummocks and hollows were avoided, as were locations of known anthropogenic disturbance. Geographic coordinates, location notes, surface vegetation, and geomorphology were recorded for each soil profile location. Excavating and coring equipment varied depending upon type of material encountered. A shovel was best suited for excavating acrotelm (aerobic zone) horizons, a McCauley peat corer was used to sample catotelm (anaerobic zone) horizons (De Vleeschouwer et al., 2010; Keys and Henderson, 1983; Klemetti and Keys, 1983), and a Dutch auger for underlying mineral soils. Profile descriptions consisted of horizon depth, Munsell ${ }^{\odot}$ color, percentage of plant fiber content, rubbed fiber content, humification based on the von Post (1924) scale, boundary transitions, and description of identifiable plant fibers.

Percentage of plant fiber content was determined in the field. Plant fibers were defined as pieces of plant tissue showing remnant cellular structure that are less than $2 \mathrm{~mm}$ in cross section, but large enough to be retained on a 100-mesh $(0.15 \mathrm{~mm})$ sieve (Buol et al., 1997). Soil Taxonomy (Soil Survey Staff, 1999) specified that living plant tissue and organic materials greater than $2 \mathrm{~mm}$ in cross section were excluded from fiber content. Rubbed fiber content was determined by rubbing the samples between the thumb and forefinger ten times, rolling the sample into a ball, breaking the ball in half, and making a visual assessment of the percentage of fibers that remain (Malterer, 2014, personal communication). Percentage of rubbed plant fibers determined the organic soil horizon designations: Oi, Oe, or Oa. Oi designated organic horizons composed of slightly decomposed fibric material (peat), with greater than $40 \%$ of fibers present after rubbing. Sphagnum moss was a strong indicator of fibric material; usually only the upper 2 
to $3 \mathrm{~cm}$ of Sphagnum is living tissue and is not considered part of the solum. The dead and decaying Sphagnum, below the upper 2 to $3 \mathrm{~cm}$, is reddish and fibrous in nature (Figure 3-3). Oe designated organic horizons with intermediate decomposition hemic material (mucky peat), with $17 \%$ to $40 \%$ of fibers present after rubbing. Hemic material typically had the look and soft feel of mature compost, it was usually brown in color with easily discernable plant fibers (Figure 34). Oa designated organic horizons that were highly decomposed sapric material (muck), with less than $17 \%$ of fibers present after rubbing. Sapric material was usually black and had a greasy feel, when air-dried it was a light-weight moderately hard mass (USDA, 2010) (Figure 3-3).

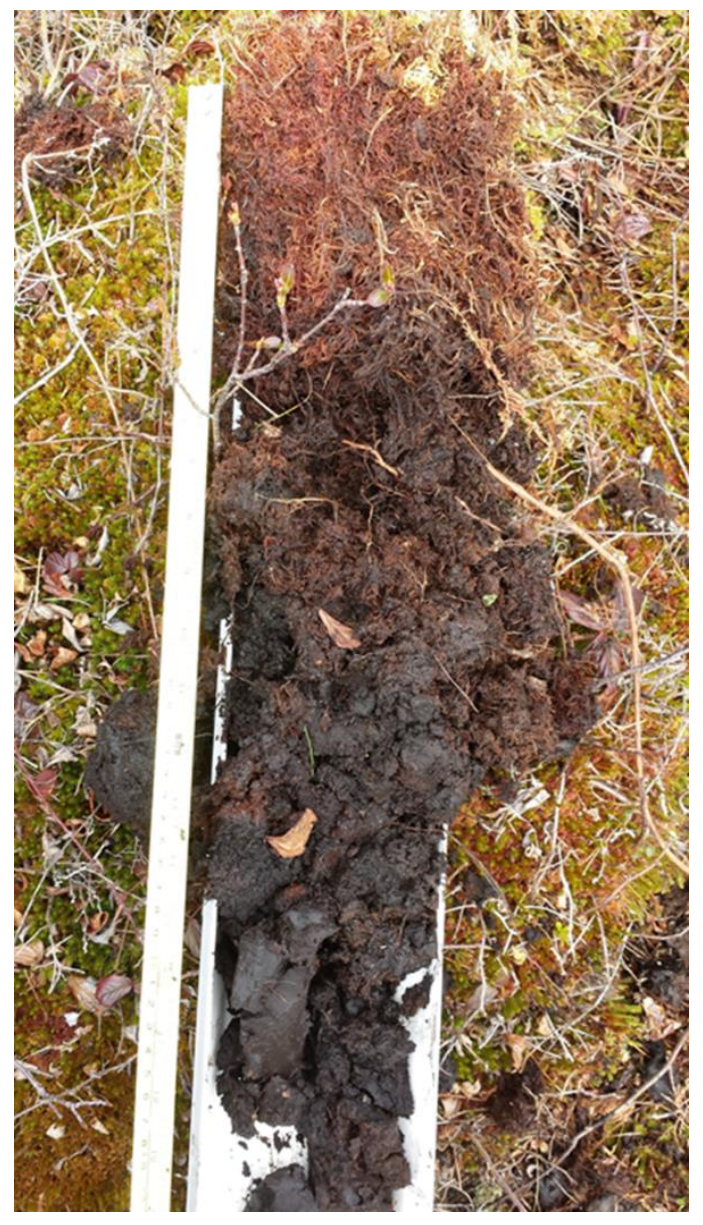

Figure 3-3. Example of CVNWR fibric (decomposing Sphagnum is the reddish material near the top of the core) and sapric soil material (black material at the bottom of the core). 


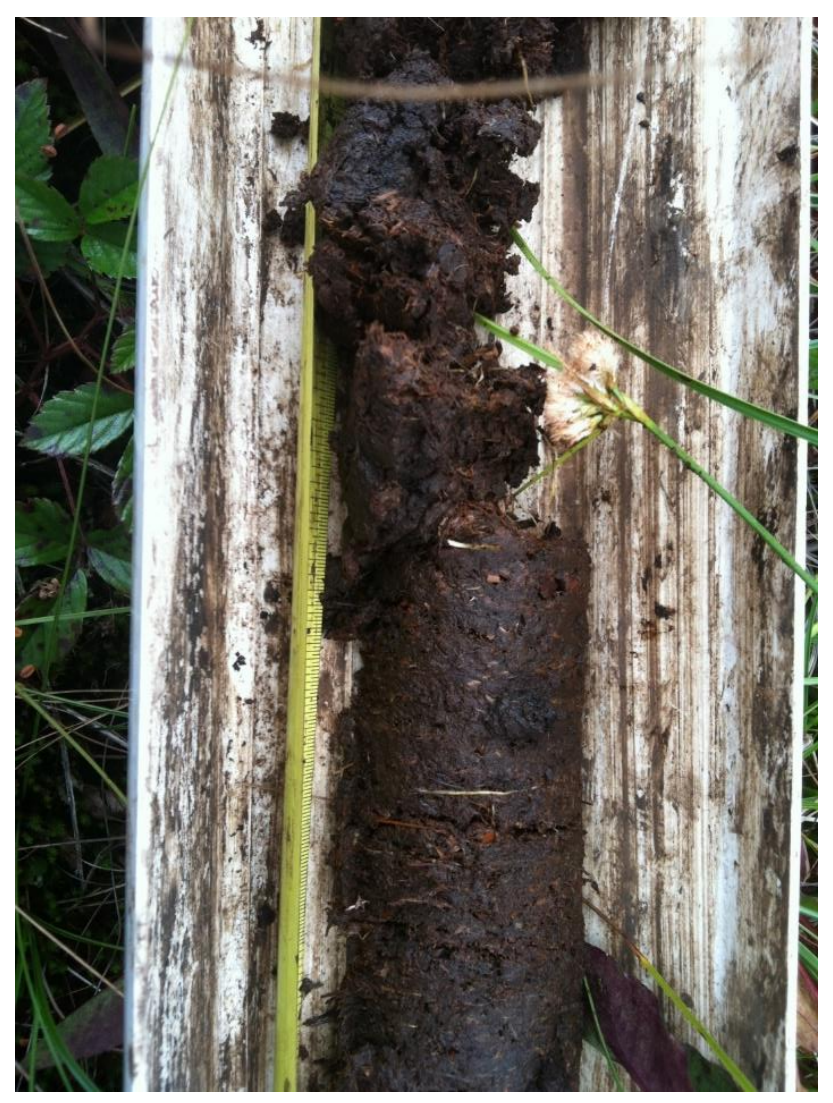

Figure 3-4. Example of CVNWR hemic soil material.

Peat humification was estimated visually with freshly extracted peat and gave a reasonably accurate assessment for field description of peat stratigraphy (Chambers et al., 2010). Humification, assigned an $\mathrm{H}$ value from 1 to 10 on the von Post scale, was gauged in the field by compressing a soil sample in one hand, catching the squeezed material and water/soil solution in the other hand. The color and turbidity of the free water and the distinctness of visible plant structure was used to assign a von Post $\mathrm{H}$ value (Smith et al., 2007; Verry et al., 2011). The von Post humification scale is used extensively outside of the United States because it is "quick and, 
with practice, is consistent, more precise, and more accurate than sieving methods" (Verry et al., 2011).

Taking into account vegetation, ecosystem, microtopography, and water depth, a minimum of two individual core locations within each peatland were selected to sample for laboratory analysis. Locations selected for laboratory analysis were cored three separate times within a $30 \mathrm{~cm}$ radius of a central point. The first core at a location was used for soil profile description, a second core for bulk density samples, and a third core for all other laboratory analysis. Bulk density samples were collected to avoid compaction and utilized careful measurements of peat volume (Chambers et al., 2010; De Vleeschouwer et al., 2010). Core samples were collected directly from a McCauley peat corer, placed in cut lengths of PVC tubes, wrapped with plastic, sealed with tape, and labeled. Due to a legacy of surface disturbance (Schaney and Schaney, in preparation) sampling shallow peat cores and sampling the acrotelm were not a focus of this research.

\section{$\underline{\text { Laboratory methods }}$}

CVNWR secured funding through U.S. Fish and Wildlife Service, in conjunction with the Radiocarbon Collaborative, sponsored jointly by the USDA Forest Service, University of California Irvine (previous mass spectrometry conducted at Lawrence Livermore National Lab in Livermore, California), and Michigan Technological University, to provide radiocarbon dating of 52 samples from 11 cores. Radiocarbon dating samples were chosen based on core location within the peatlands and horizon depth within the profile, focusing on basal peat dates, horizon breaks within the catotelm, and sedimentary sequence of the deepest cores (Givelet et al., 2004; Piotrowska et al., 2010; Tuittila et al., 2012). Standard radiocarbon ages were calibrated to dates 
(cal yr BP) using OxCal 4.2 and IntCal13 Northern Hemisphere calibration curve (Bronk Ramsey, 2009; Reimer et al., 2013).

Bulk density, organic matter content, fiber content, and pyrophosphate color laboratory analysis on individual horizons in each of the 30 laboratory analysis cores were conducted in the labs of the Division of Plant and Soil Sciences of West Virginia University. Laboratory analysis procedures in the UDSA-NRCS Kellogg Soil Survey Laboratory Methods Manual (Soil Survey Staff, 2014) were followed, with the explicit intention of soil classification according to Soil Taxonomy (Soil Survey Staff, 1999).

Bulk density is an indirect measure of organic soil decomposition (Boelter, 1968). Lessdecomposed peat tended to be of low bulk density and were likely deposited under wet conditions that promoted rapid accumulation and burial of organic matter (Chambers et al., 2010). More-decomposed, or humified, muck tended to be of higher bulk density and was likely deposited under dryer conditions with slow accumulation and burial of organic material. Organic matter bulk density was used as a simple proxy of the varying degree of total peat decomposition and to infer past surface moisture conditions (Boelter, 1968; Yu et al., 2003; Chambers et al., 2010). Bulk density was measured in the laboratory using oven-dried weight of a known volume of organic soil sample.

Organic matter content is naturally high in peatlands but can vary substantially because of mineral inputs including exogenous waterborne and wind-blown material (Chambers et al., 2010). Loss on ignition was utilized to determine mineral and organic matter contents of the soils. Mineral content consists of ash and mineral particles that remain after removal of organic matter. Determination of organic matter by loss on ignition was a taxonomic criterion for 
organic soil materials (Soil Survey Staff, 2014). Organic matter content was calculated by taking the dry weight minus weight after ashing overnight at $550^{\circ} \mathrm{C}$, divided by dry weight.

Percentage of plant fibers is used in Soil Taxonomy to determine sapric, hemic, and fibric organic materials for classification (Soil Survey Staff, 2010, 2014; Stolt and Bakken, 2014). Fiber content can be complex and variable, differing between soil horizons, as well as laterally across a peatland (Soil Survey Staff, 2014). Using known-volume samples and washing through a 100 -mesh $(0.15 \mathrm{~mm})$ sieve with tap water, the percentage of fibers retained on the sieve was estimated, then rubbed and washed again, to determine rubbed fiber content and thus the decomposition state of soil organic matter and horizon designation (Soil Survey Staff, 1999; 2014).

Pyrophosphate color was another requirement utilized for determining decomposition class for taxonomic classification of Histosols (Soil Survey Staff, 2010; Stolt and Bakken, 2014). Procedures for testing pyrophosphate color entailed adding an aqueous sodium pyrophosphate solution to a pre-measured soil sample. Color value and chroma of the extract was evaluated by moistening a chromatographic strip in the solution and comparing color with the $10 \mathrm{YR}$ Munsell ${ }^{\odot}$ soil color chart (Verry, 2011; Soil Survey Staff, 1999; 2014).

\section{Results}

Generally, most soil profiles in CVNWR peatlands had similar horizonation trends. The acrotelm consisted of approximately $20 \mathrm{~cm}$ of fibric soil material, typically underlain by less than $10 \mathrm{~cm}$ of sapric soil material located at the water table. The catotelm consisted of various thicknesses of a combination of hemic and sapric soil materials. Radiocarbon dates and peat accumulation rates reported in Table 3-1 were discussed in length in Chapter 2. Sequential radiocarbon dates were obtained for seven cores, six of which (Cores 1.86, 2.09, 3.13, 4.19, 5.12, 
and 5.17) had basal peat dates ranging from $\sim 18,600$ to $\sim 15,200$ cal yr BP, during or immediately after Heinrich Stadial 1 correlating to a hemic soil horizon that also spanned the Greenlandian Age. These cores also all contained a sapric horizon dating to the Northgrippian Age and another hemic horizon dating to the Meghalayan Age. The seventh core (Core 4.02) with sequential radiocarbon dates, had a late Northgrippian Age basal peat date of $\sim 4,600 \mathrm{cal} \mathrm{yr}$ BP. Peat accumulation rates (Table 3-1) were calculated as the thickness of accumulated peat in mm divided by the corresponding radiocarbon dated interval (Borren et al., 2004). Peat accumulation rates varied from a maximum of $1.34 \mathrm{~mm} / \mathrm{yr}$ to a minimum of $0.02 \mathrm{~mm} / \mathrm{yr}$, with a mean of $0.14 \mathrm{~mm} / \mathrm{yr}$ (calculated as the mean of the overall whole core rates at each core with sequential dates). Peat accumulation rates between $\sim 15,800$ and $\sim 12,500$ cal yr BP averaged $0.24 \mathrm{~mm} / \mathrm{yr}$. Net peat accumulation declined to a mean of $0.11 \mathrm{~mm} / \mathrm{yr}$ between $\sim 11,700$ and $\sim 8,600$ cal yr BP, generally correlating to the Greenlandian Age. Few radiocarbon dates were obtained on peat of Northgrippian Age, hence only two cores include well-constrained midHolocene peat accumulation rates. Core 3.13 had a peat accumulation rate of $0.02 \mathrm{~mm} / \mathrm{yr}$ between $\sim 11,700$ and $\sim 5,900 \mathrm{cal} \mathrm{yr} \mathrm{BP}$, and Core 5.17 had a peat accumulation rate of 0.04 $\mathrm{mm} / \mathrm{yr}$ between $\sim 10,300$ and $\sim 5,400 \mathrm{Cal} \mathrm{yr}$ BP. These may be the lowest of any time since the onset of peat accumulation, a trend reinforced by the scarcity of peat of this age. Exceptionally high peat accumulation rates between $\sim 4,200$ and $\sim 2,000$ cal yr BP averaged $0.50 \mathrm{~mm} / \mathrm{yr}$, coeval with the onset of the Meghalayan Age. The last 2,000 years of peat development in CVNWR was represented by only three dates, but generally show very low peat accumulations rates averaging $0.08 \mathrm{~mm} / \mathrm{yr}$, which may reflect a reduction in peat accumulation, or mixing of surface vegetation into near-surface soil horizons. 


\begin{tabular}{|c|c|c|c|c|c|c|c|c|c|}
\hline \multirow[t]{2}{*}{$\begin{array}{r}\text { Laboratory } \\
\text { ID }\end{array}$} & \multirow[t]{2}{*}{ Sample \# } & \multirow[t]{2}{*}{ Core \# } & \multirow[t]{2}{*}{ Depth (cm) } & \multicolumn{2}{|c|}{ Standard Radiocarbon Age } & \multicolumn{2}{|c|}{$\begin{array}{r}\text { intCal13 Calibrated } \\
\text { Dates } 95 \% \text { confidence } \\
\text { interval } \\
\end{array}$} & \multirow{2}{*}{$\begin{array}{r}\text { Median } \\
\text { cal yr } \\
\text { BP }\end{array}$} & \multirow[t]{2}{*}{$\begin{array}{r}\text { Accumulation } \\
\text { Rate } \mathbf{m m} / \mathbf{y r}\end{array}$} \\
\hline & & & & ${ }^{14} \mathrm{C}$ age & \pm & & $\mathrm{m} \quad$ To & & \\
\hline CAMS-171742 & 25 & 1.82 & $128-130$ & 12810 & 40 & 15449 & 15109 & 15258 & \\
\hline CAMS-172756 & 32 & 1.86 & $2-4$ & 1225 & 30 & 1260 & 1065 & 1153 & 0.05 \\
\hline CAMS-172757 & 33 & 1.86 & $40-42$ & 7880 & 35 & 8953 & 8587 & 8675 & 0.08 \\
\hline CAMS-172762 & 38 & 1.86 & $59-61$ & 9600 & 30 & 11128 & 10774 & 10928 & 0.18 \\
\hline CAMS-172763 & 39 & 1.86 & $86-88$ & 10475 & 35 & 12560 & 12147 & 12451 & $0.82_{+}$ \\
\hline CAMS-172764 & 40 & 1.86 & $100-102$ & 10635 & 30 & 12690 & 12559 & 12621 & $0.08_{+}$ \\
\hline CAMS-171738 & 21 & 1.86 & $127-129$ & 13155 & 40 & 16002 & 15637 & 15807 & \\
\hline CAMS-171739 & 22 & 2.05 & $119-121$ & 15045 & 40 & 18435 & 18099 & 18284 & \\
\hline CAMS-172760 & 36 & 2.09 & $15-17$ & 3550 & 35 & 3960 & 3720 & 3844 & 0.05 \\
\hline CAMS-172761 & 37 & 2.09 & $40-42$ & 8035 & 35 & 9021 & 8775 & 8909 & 0.04 \\
\hline CAMS-172758 & 34 & 2.09 & $65-67$ & 12455 & 45 & 14961 & 14251 & 14598 & 0.16 \\
\hline CAMS-172759 & 35 & 2.09 & $80-82$ & 12985 & 40 & 15732 & 15315 & 15528 & 0.33 \\
\hline CAMS-171737 & 20 & 2.09 & $92-94$ & 13225 & 40 & 16069 & 15730 & 15896 & \\
\hline CAMS-172750 & 26 & 3.13 & $11-13$ & 1925 & 30 & 1947 & 1817 & 1873 & 0.11 \\
\hline CAMS-170482 & 10 & 3.13 & $27-29$ & 3155 & 30 & 3450 & 3269 & 3382 & 0.45 \\
\hline CAMS-172751 & 27 & 3.13 & $50-52$ & 3590 & 30 & 3977 & 3833 & 3894 & 0.07 \\
\hline CAMS-170483 & 11 & 3.13 & $64-66$ & 5180 & 30 & 5991 & 5905 & 5936 & 0.02 \\
\hline CAMS-172752 & 28 & 3.13 & $75-77$ & 10095 & 40 & 11954 & 11404 & 11687 & 0.06 \\
\hline CAMS- 172753 & 29 & 3.13 & $83-85$ & 11085 & 35 & 13063 & 12824 & 12960 & 0.20 \\
\hline CAMS-170484 & 12 & 3.13 & $94-96$ & 11680 & 30 & 13570 & 13445 & 13510 & 0.08 \\
\hline CAMS-172754 & 30 & 3.13 & $120-122$ & 13815 & 40 & 16946 & 16488 & 16715 & 0.23 \\
\hline CAMS-170485 & 13 & 3.13 & $165-167$ & 15375 & 35 & 18759 & 18544 & 18653 & \\
\hline CAMS-171740 & 23 & 3.14 & $121-123$ & 13870 & 40 & 17009 & 16573 & 16802 & \\
\hline CAMS-170478 & 6 & 4.02 & $7-9$ & 420 & 35 & 530 & 326 & 486 & 0.06 \\
\hline CAMS-170479 & 7 & 4.02 & $17-20$ & 2130 & 30 & 2299 & 2001 & 2111 & 0.44 \\
\hline CAMS-170480 & 8 & 4.02 & $76-79$ & 3240 & 30 & 3560 & 3388 & 3460 & 0.35 \\
\hline CAMS-170481 & 9 & 4.02 & $117-120$ & 4095 & 35 & 4814 & 4446 & 4607 & \\
\hline CAMS-172755 & 31 & 4.09 & $151-152$ & 4380 & 40 & 5212 & 4852 & 4942 & \\
\hline CAMS- 172770 & 46 & 4.19 & $30-32$ & 2490 & 30 & 2730 & 2460 & 2584 & 0.61 \\
\hline CAMS-172771 & 47 & 4.19 & $60-62$ & 2925 & 30 & 3164 & 2971 & 3072 & 0.52 \\
\hline CAMS-172772 & 48 & 4.19 & $80-82$ & 3235 & 30 & 3558 & 3385 & 3453 & 0.58 \\
\hline CAMS-172773 & 49 & 4.19 & $120-122$ & 3775 & 35 & 4281 & 3992 & 4146 & 0.05 \\
\hline CAMS-172774 & 50 & 4.19 & $165-167$ & 11235 & 35 & 13164 & 13041 & 13097 & 0.21 \\
\hline CAMS-171741 & 24 & 4.19 & 211-213 & 12850 & 40 & 15545 & 15160 & 15315 & \\
\hline CAMS-170473 & 1 & 5.12 & $16-20$ & 2080 & 30 & 2140 & 1952 & 2050 & 0.64 \\
\hline CAMS-170474 & 2 & 5.12 & $51-53$ & 2495 & 30 & 2732 & 2466 & 2585 & 1.34 \\
\hline CAMS-170475 & 3 & 5.12 & $82-85$ & 2725 & 30 & 2873 & 2761 & 2817 & 0.04 \\
\hline CAMS-170476 & 4 & 5.12 & $114-116$ & 9010 & 30 & 10235 & 10170 & 10204 & 0.15 \\
\hline CAMS-170477 & 5 & 5.12 & 197-199 & 13105 & 35 & 15940 & 15540 & 15733 & \\
\hline CAMS-171732 & 15 & 5.17 & $18-20$ & 2070 & 30 & 2123 & 1950 & 2039 & 0.68 \\
\hline CAMS-171733 & 16 & 5.17 & $70-72$ & 2705 & 30 & 2857 & 2756 & 2804 & 0.39 \\
\hline CAMS-172765 & 41 & 5.17 & $85-87$ & 3800 & 30 & 4288 & 4088 & 4187 & \\
\hline CAMS-174232 & $41 *$ & 5.17 & $82-84$ & 2970 & 30 & 3230 & 3007 & 3135 & 0.37 \\
\hline CAMS-172766 & 42 & 5.17 & $120-122$ & 2930 & 30 & 3169 & 2974 & 3080 & \\
\hline CAMS-174233 & $42 *$ & 5.17 & $122-124$ & 3820 & 40 & 4406 & 4091 & 4217 & 0.07 \\
\hline CAMS-172767 & 43 & 5.17 & $130-132$ & 4580 & 30 & 5447 & 5066 & 5302 & $0.63_{+}$ \\
\hline CAMS-172768 & 44 & 5.17 & $140-142$ & 4720 & 45 & 5584 & 5322 & 5460 & $0.04_{+}$ \\
\hline CAMS-171736 & 19 & 5.17 & $161-163$ & 9160 & 45 & 10483 & 10231 & 10323 & 0.12 \\
\hline CAMS-172769 & 45 & 5.17 & $173-175$ & 9930 & 30 & 11590 & 11241 & 11312 & 0.12 \\
\hline CAMS-171735 & 18 & 5.17 & $196-198$ & 11360 & 35 & 13290 & 13115 & 13203 & 0.28 \\
\hline CAMS-171734 & 17 & 5.17 & $225-227$ & 12310 & 35 & 14531 & 14075 & 14237 & 0.55 \\
\hline CAMS-171731 & 14 & 5.17 & $288-290$ & 12890 & 40 & 15598 & 15210 & 15382 & \\
\hline
\end{tabular}


Table 3- 1. CVNWR radiocarbon dates and accumulation rates. Dated material consisted entirely of bulk peat samples. Accumulation rates were calculated as the thickness of accumulated peat divided by the corresponding interval between calibrated median radiocarbon ages. Samples 41 and 42 were reanalyzed due to a stratigraphic inversion, likely caused by procedural error. Dates on samples $41^{*}$ and $42 *$ were in expected stratigraphic order, so these age determinations were used in analysis and interpretation. The + symbol denotes radiocarbon dates with overlapping 95\% confidence intervals; mid-points were used to calculate a peat accumulation rates which were used for data interpretation.

The field investigation resulted in re-mapping the five pre-existing NRCS soil polygons, originally totaling 187 hectares, now totaling 246 hectares (Figure 3-2). Out of the 100 soil profiles examined for this study, 12 were determined to be Entisols and will not be discussed further. The 88 remaining Histosol profiles were separated into five types (A, B, C, D, and E) based upon the sequence of horizons in the catotelm (Table 3-2 and Figure 3-5). Soil profiles investigated in CVNWR peatlands have very similar acrotelm horizonation. The acrotelm usually consists of $\sim 20 \mathrm{~cm}$ of fibric soil material, underlain by $\sim 10 \mathrm{~cm}$ of sapric soil material located near the water table. This sapric horizon at the water table has the greatest humification (Vitt et al., 2009) throughout the project area. Due to the legacy of surface disturbance possible with the CVNWR peatlands, it was determined by the authors that pedomemory within the peat stratigraphy was best retained within the catotelm, which has a slow decomposition rate (Clymo, 1984) and no apparent history of disturbance (Schaney and Schaney, in preparation). CVNWR soil profile catotelms consisted of varying thicknesses of a combination of hemic and sapric soil materials (Figure 3-6). Figure 3-6 shows the generalized pedogenic development of the five types (A, B, C, D, and E) of catotelm horizon sequences represented in the 88 Histosol profiles at CVNWR; each is discussed below. 


\begin{tabular}{|c|c|c|c|c|c|c|c|c|c|c|c|c|}
\hline \multirow{2}{*}{\multicolumn{2}{|c|}{ Soil Profile Type }} & \multicolumn{2}{|c|}{ Peatland 1} & \multicolumn{2}{|c|}{ Peatland 2} & \multicolumn{2}{|c|}{ Peatland 3} & \multicolumn{2}{|c|}{ Peatland 4} & \multicolumn{2}{|c|}{ Peatland 5} & \multirow{2}{*}{$\begin{array}{l}\text { Type } \\
\text { Totals }\end{array}$} \\
\hline & & Cores & Data & Cores & Data & Cores & Data & Cores & Data & Cores & Data & \\
\hline \multirow{5}{*}{ Type A (H) } & & 2 & & $\mathbf{0}$ & & 4 & & 3 & & 1 & & 10 \\
\hline & with lab data and C14 dates & & 0 & & 0 & & 0 & & 0 & & 0 & \\
\hline & with $\mathrm{C} 14$ dates & & 0 & & 0 & & 0 & & 2 & & 0 & \\
\hline & with lab data & & 0 & & 0 & & 0 & & 0 & & 0 & \\
\hline & only field descriptions & & 2 & & 0 & & 4 & & 1 & & 1 & \\
\hline \multirow[t]{5}{*}{ Type B (SH) } & & 17 & & 4 & & 2 & & $\mathbf{0}$ & & 1 & & 24 \\
\hline & with lab data and C14 dates & & 2 & & 2 & & 0 & & 0 & & 0 & \\
\hline & with $C 14$ dates & & 0 & & 1 & & 1 & & 0 & & 0 & \\
\hline & with lab data & & 2 & & 1 & & 0 & & 0 & & 0 & \\
\hline & only field descriptions & & 13 & & 1 & & 1 & & 0 & & 1 & \\
\hline \multirow[t]{5}{*}{ Type C (HSH) } & & $\mathbf{0}$ & & 2 & & 6 & & 6 & & 13 & & 27 \\
\hline & with lab data and C14 dates & & 0 & & 0 & & 1 & & 1 & & 1 & \\
\hline & with C14 dates & & 0 & & 0 & & 0 & & 0 & & 1 & \\
\hline & with lab data & & 0 & & 2 & & 0 & & 0 & & 4 & \\
\hline & only field descriptions & & 0 & & 0 & & 5 & & 5 & & 7 & \\
\hline \multirow[t]{5}{*}{ Type D (S) } & & 3 & & 3 & & 3 & & 2 & & $\mathbf{0}$ & & 11 \\
\hline & with lab data and C14 dates & & 0 & & 0 & & 0 & & 0 & & 0 & \\
\hline & with C14 dates & & 0 & & 0 & & 0 & & 0 & & 0 & \\
\hline & with lab data & & 0 & & 0 & & 0 & & 0 & & 0 & \\
\hline & only field descriptions & & 3 & & 3 & & 3 & & 2 & & 0 & \\
\hline \multirow[t]{5}{*}{ Type E (HS) } & & 3 & & $\mathbf{0}$ & & 4 & & 8 & & 1 & & 16 \\
\hline & with lab data and C14 dates & & 0 & & 0 & & 0 & & 0 & & 0 & \\
\hline & with C14 dates & & 0 & & 0 & & 0 & & 0 & & 0 & \\
\hline & with lab data & & 0 & & 0 & & 3 & & 3 & & 1 & \\
\hline & only field descriptions & & 3 & & 0 & & 1 & & 5 & & 0 & \\
\hline \multicolumn{2}{|c|}{ Totals for each peatland } & 25 & & 9 & & 19 & & 19 & & 16 & & 88 \\
\hline
\end{tabular}

Table 3- 2. Profile type distribution amongst the five peatlands. 


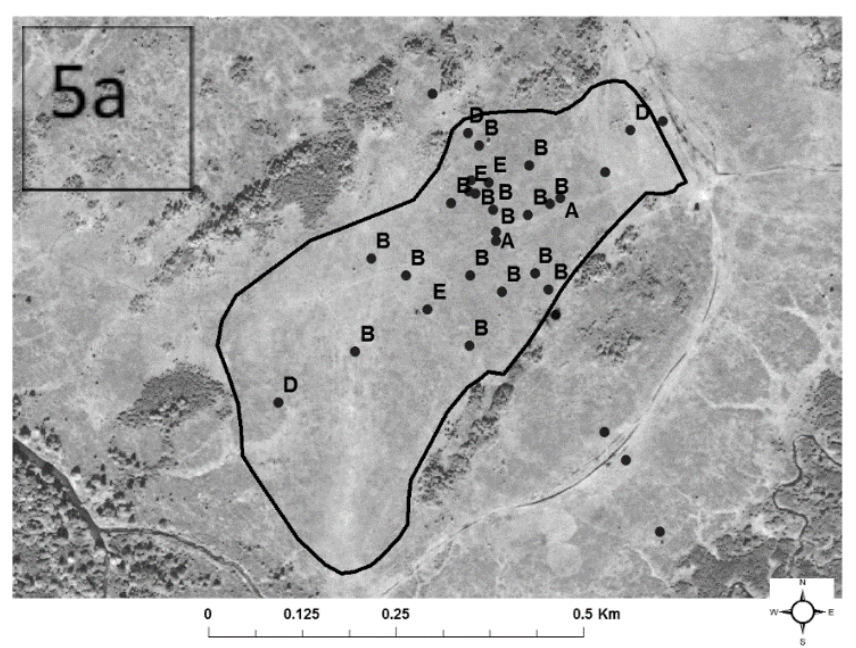

Figure 3- 5. Five CVNWR peatlands with soil cores labeled by soil profile type: $5 \mathrm{a}$.

Peatland 1, 25 cores, dominated by Type B (SH) profiles; 5b. Peatland 29 cores; $5 \mathrm{c}$. Peatland 319 cores, including all five soil types; 5d. Peatland 419 cores, including Type $\mathrm{C}(\mathrm{HSH})$ profiles clustered at the thickest peat, surrounded by Type E (HS) profiles, and a cluster of Type A $(\mathrm{H})$ profiles; 5e. Peatland 5, 16 cores, dominated by Type $\mathrm{C}(\mathrm{HSH})$ profiles.
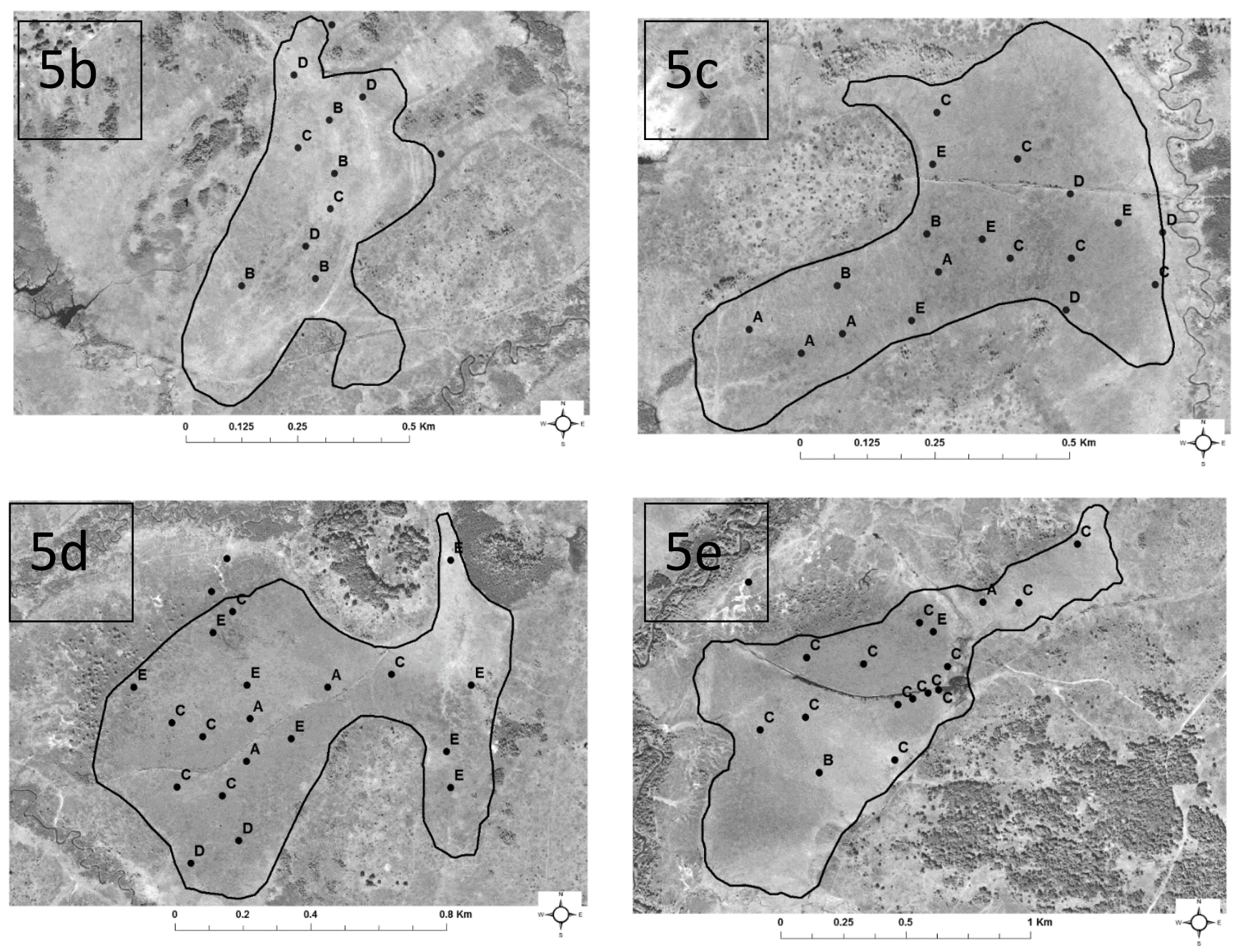


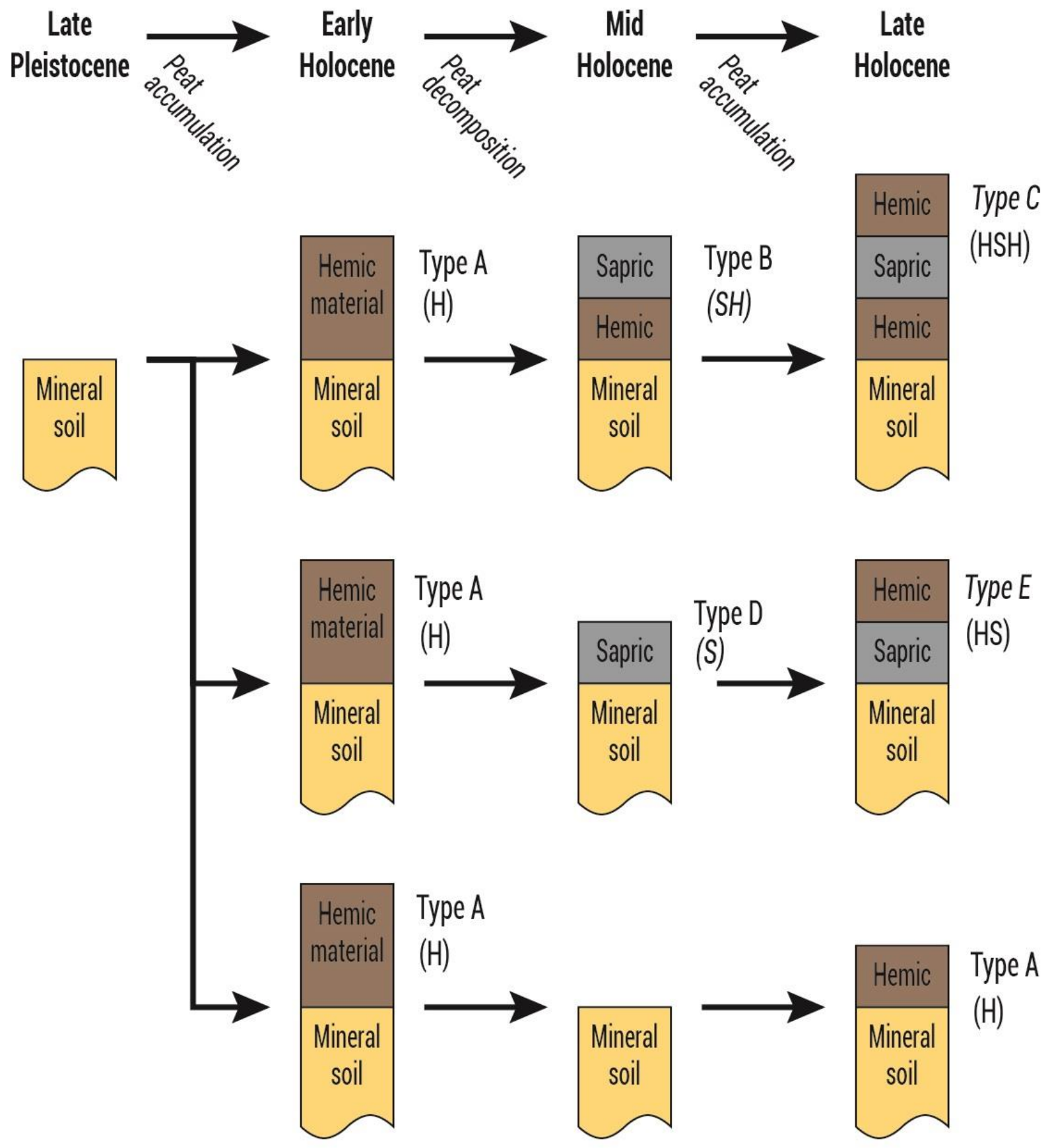

Figure 3- 6. Possible development pathways for the five profiles types amongst CVNWR organic soil cores. 
Type A soil profiles (Figure 3-7) had a catotelm comprised entirely of hemic soil horizons $(\mathrm{H})$. This horizonation occurred in four of the five peatlands (Table 3-2 and Figure 35). Of these 10 soil profiles, two had radiocarbon dates and none had laboratory data. Sequential radiocarbon dates in Core 4.02 (Figure 3-7) and a basal peat date in Core 4.09, show that these Type A (H) profiles had basal peat dates of 4,600 cal yr BP and 4,900 cal yr BP respectively. The late Northgrippian peat initiation in these two Type A $(\mathrm{H})$ soil profile was $>10,000$ years younger than the onset of peat accumulation in other dated CVNWR cores.

Type B soil profiles (Figure 3-8) had a catotelm sequence of a sapric horizon underlain by a hemic horizon (SH). This horizonation occurred in four of the five peatlands (Table 3-2 and Figure 3-5). This profile type was more numerous in the shallow peatlands. Type B (SH) profiles comprised almost all of Peatland 1, surrounded the cluster of Type C (HSH) profiles in Peatland 2, were nestled next to an upland bedrock area in Peatland 3, were not represented in Peatland 4, and were insignificant in Peatland 5. Of these 24 soil profiles, three had laboratory data and radiocarbon dates, two had only radiocarbon dates, and three had only laboratory dates. Two cores (1.86 and 2.09) with sequential radiocarbon dates had Type B (SH) soil profiles, with a catotelm sapric horizon spanning the Northgrippian Age (Figure 3-8).

Type $\mathrm{C}$ soil profiles had a distinct horizonation (Figures 3-6 and 3-9) with a catotelm layered as a hemic soil horizon, underlain by a sapric horizon, underlain by another hemic horizon (HSH). This distinct Type $\mathrm{C}(\mathrm{HSH})$ horizonation was the most numerous of the 88 profiles examined and occurred in four of the five peatlands (Table 3-2 and Figure 3-5). This profile type was more numerous in larger and deeper peatlands. Type $\mathrm{C}(\mathrm{HSH})$ soil profiles occurred clustered in the center of Peatlands 2, 3, and 4, and comprised almost all of Peatland 5. Of 27 Type $\mathrm{C}$ soil profiles, three had laboratory data and radiocarbon dates, one had only 
radiocarbon dates, and five had only laboratory data. Four cores $(3.13,4.19,5.12$, and 5.17) with sequential radiocarbon dates had Type $\mathrm{C}(\mathrm{HSH})$ soil profiles, with a catotelm sapric horizon dating to the Northgrippian Age (Figure 3-9).

Type D soil profiles (Figure 3-10) had a catotelm comprised entirely of sapric soil horizons (S). This horizonation occurred in four of the five peatlands (Table 3-2 and Figure 3-5). Most Type D (S) soil profiles occurred along the periphery of the shallow peatlands. None of these 11 soil profiles had laboratory data or radiocarbon dates.

Type E soil profiles had a catotelm sequence of a hemic horizon underlain by a sapric horizon (HS) (Figure 3-11). This horizonation occurred in four of the five peatlands (Table 3-2 and Figure 3-5). Type E (HS) soil profiles typically occurred surrounding clusters of Type C (HSH) soil profiles. Type E (HS) profiles were generally shallower than Type C (HSH) profiles. Of 16 soil Type E profiles, seven had laboratory data but none had radiocarbon dates.

Figure 3-5 summarizes the geographical distribution of soil profile types. Peatland 1 had the most cores and was dominated by Type B (SH) profiles. Peatland 1 was the easiest to access for field visits, and had the most soil profiles, biasing statistics on Type B (SH) profiles. Peatland 2 had the fewest cores, and a pattern of Type $\mathrm{C}(\mathrm{HSH})$ profile in the center surrounded by Type B (SH) profiles, and Type D (S) profiles in shallow areas peats along the periphery. Peatland 3 had clusters of all five profile types. Peatland 4 had Type $\mathrm{C}(\mathrm{HSH})$ profiles clustered on the thickest peat, surrounded by Type E (HS) profiles, and a patch of Type A (H) profiles. Peatland 5 was the largest peatland and was dominated by Type $\mathrm{C}(\mathrm{HSH})$ profiles. 


\section{Core 4.02}

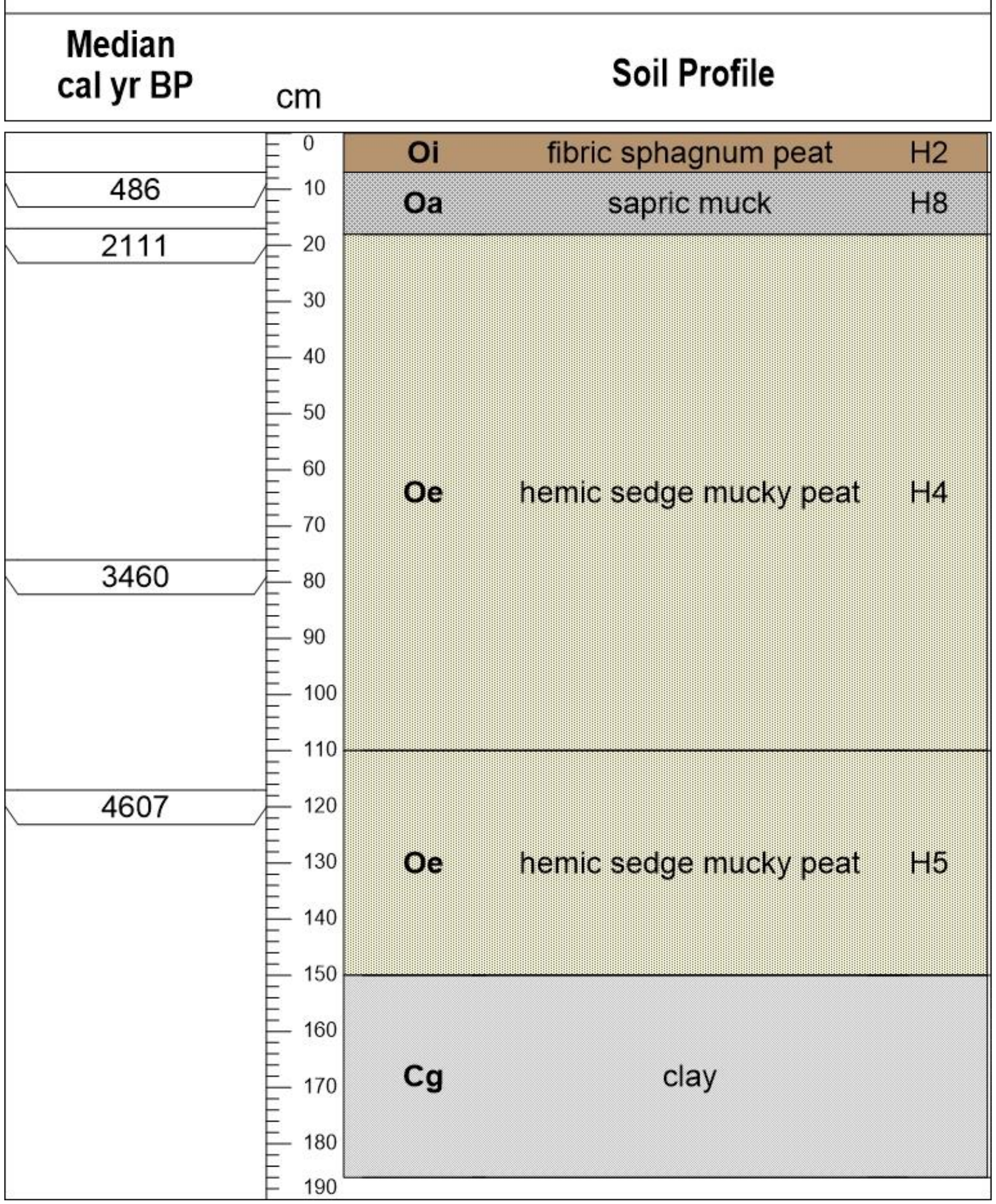

Figure 3- 7. Soil profile of Core 4.02, representing Type A (H) profiles. 


\section{Core 1.86}

Median cal yr BP
Soil Profile

\section{Fiber Bulk \\ Content Density}

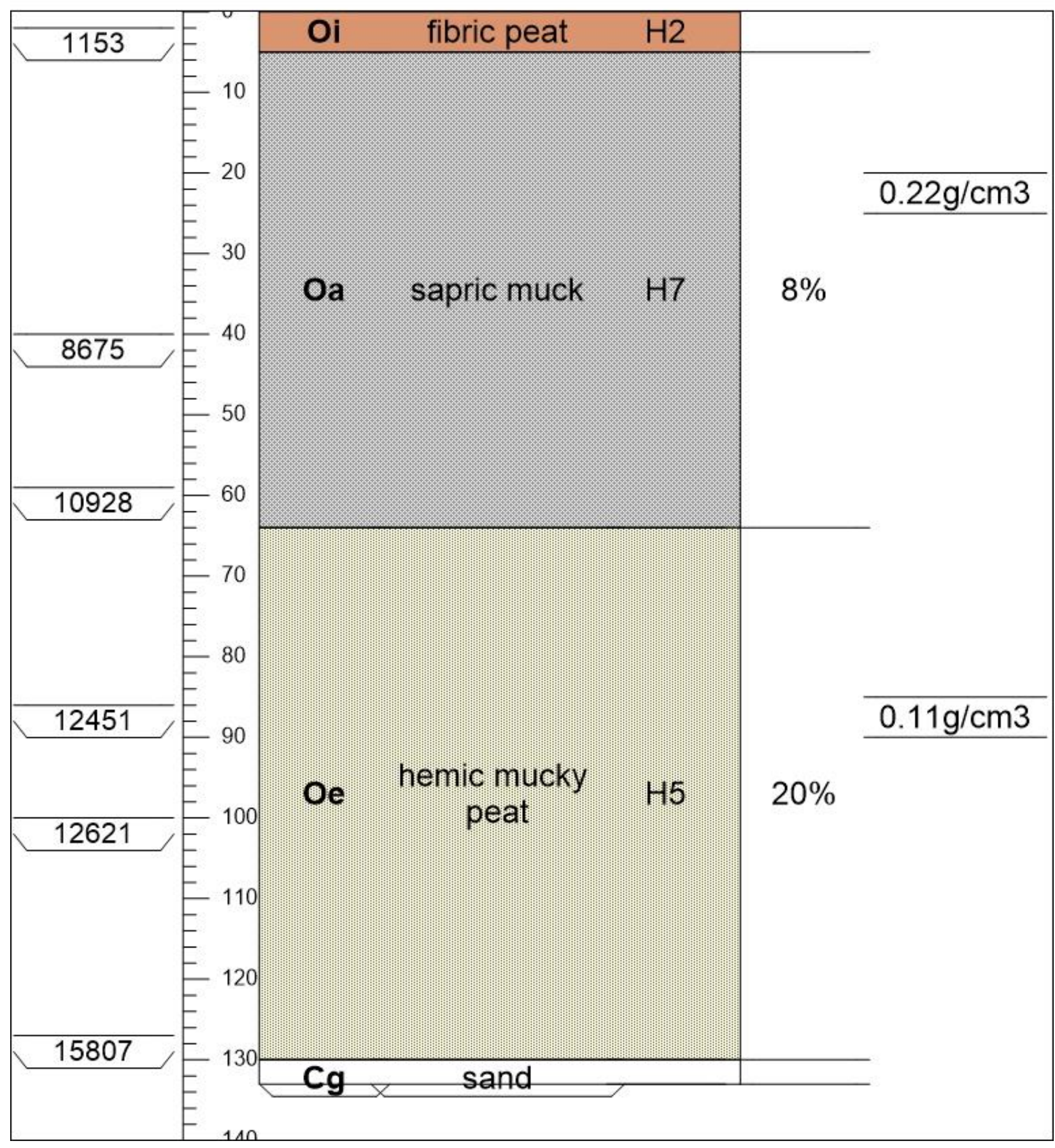

Figure 3- 8. Soil profile of Core 1.86, representing Type B (SH) profiles. 


\section{Core 5.17}

\section{Median cal yr BP cm \\ Soil Profile \\ $\begin{array}{cc}\text { Fiber } & \text { Bulk } \\ \text { Content } & \text { Density }\end{array}$}

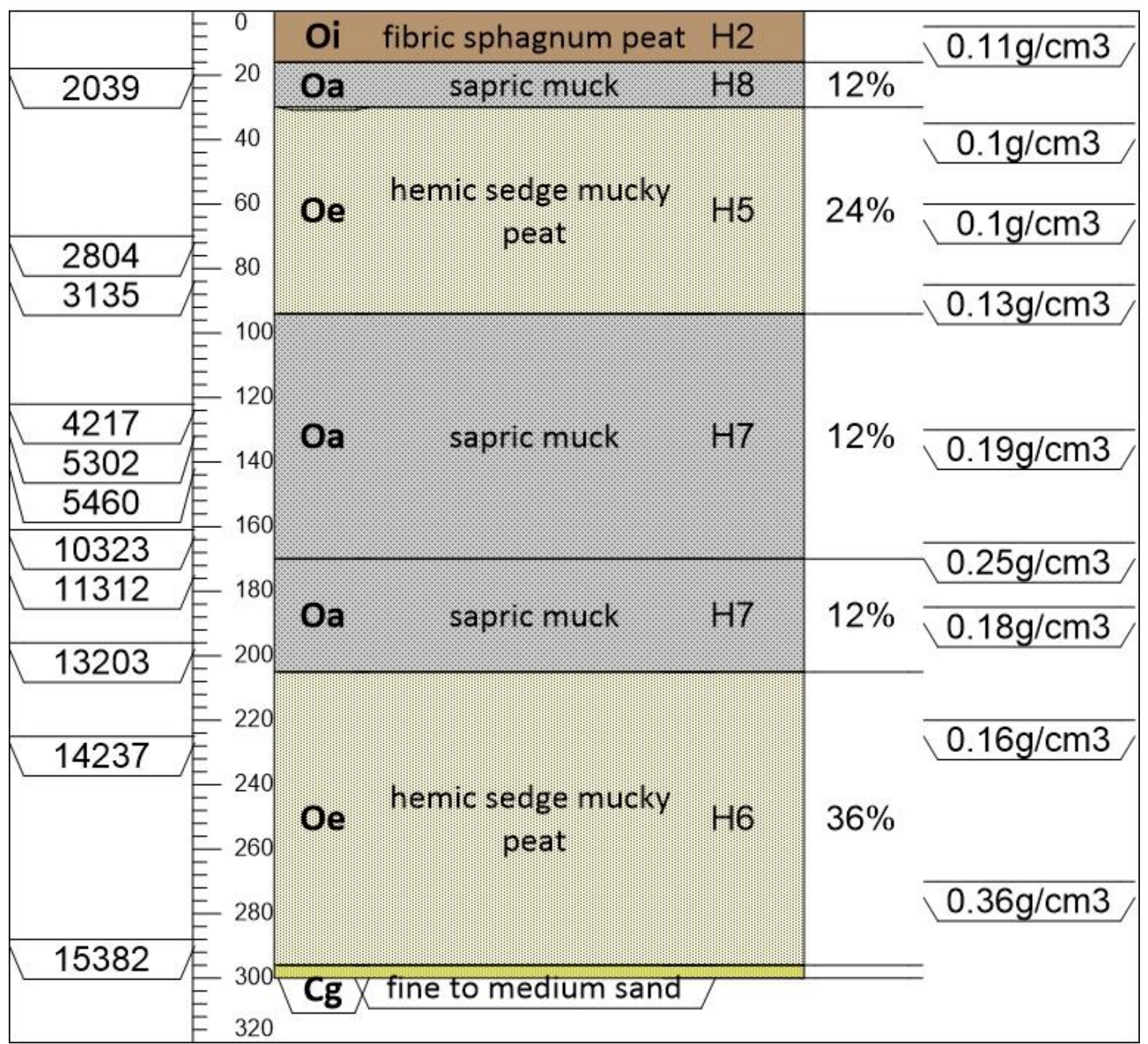

Figure 3- 9. Soil profile of Core 5.17, representing Type C (HSH) profiles. 


\section{Core 2.07}

\begin{tabular}{|c|c|}
\hline $\mathrm{cm}$ & Soil Profile \\
\hline
\end{tabular}

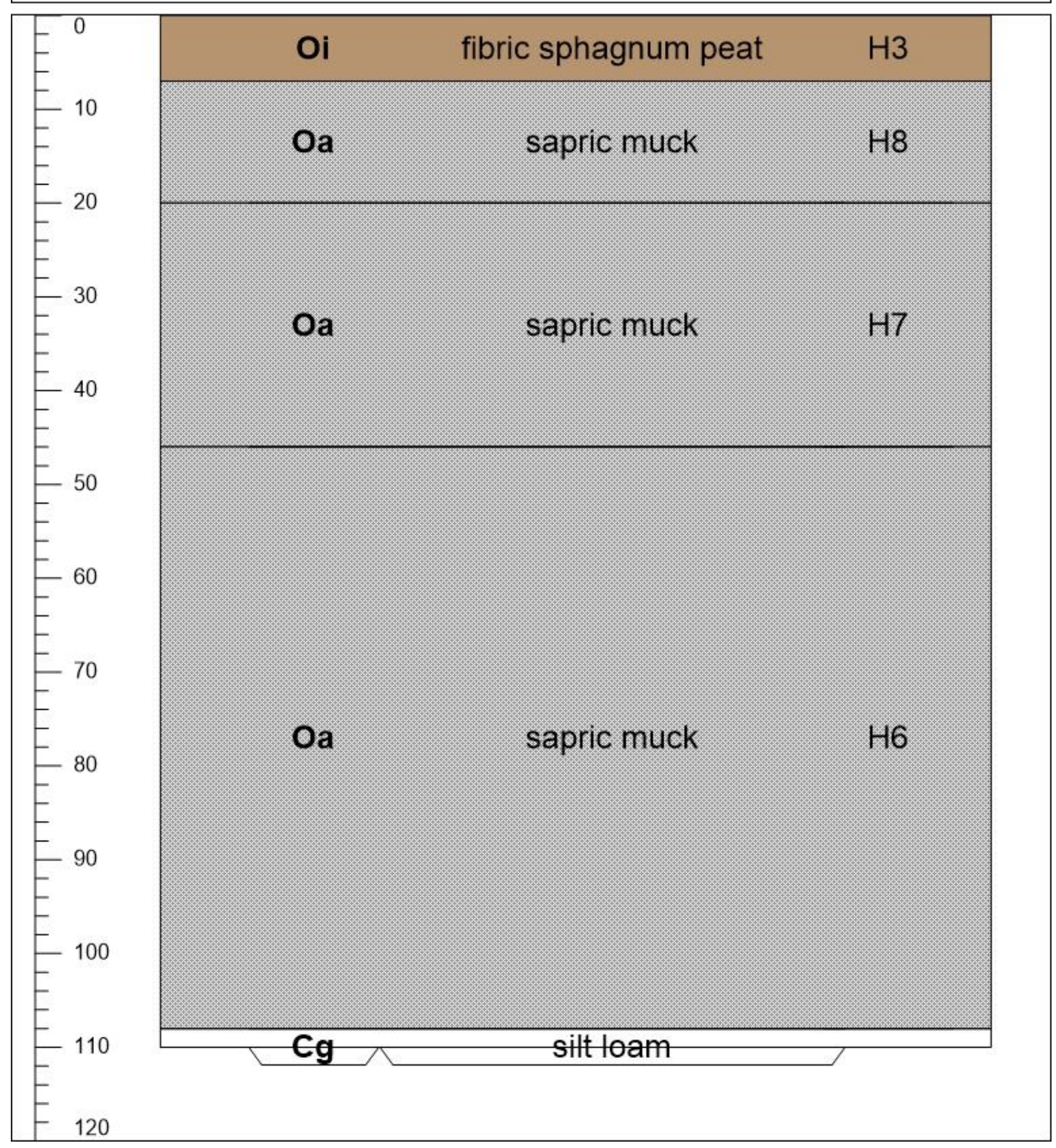

Figure 3- 10. Soil profile of Core 2.07, representing Type D (S) profiles. 


\section{Core 3.17}

$\mathrm{cm}$ Soil Profile

Bulk Density

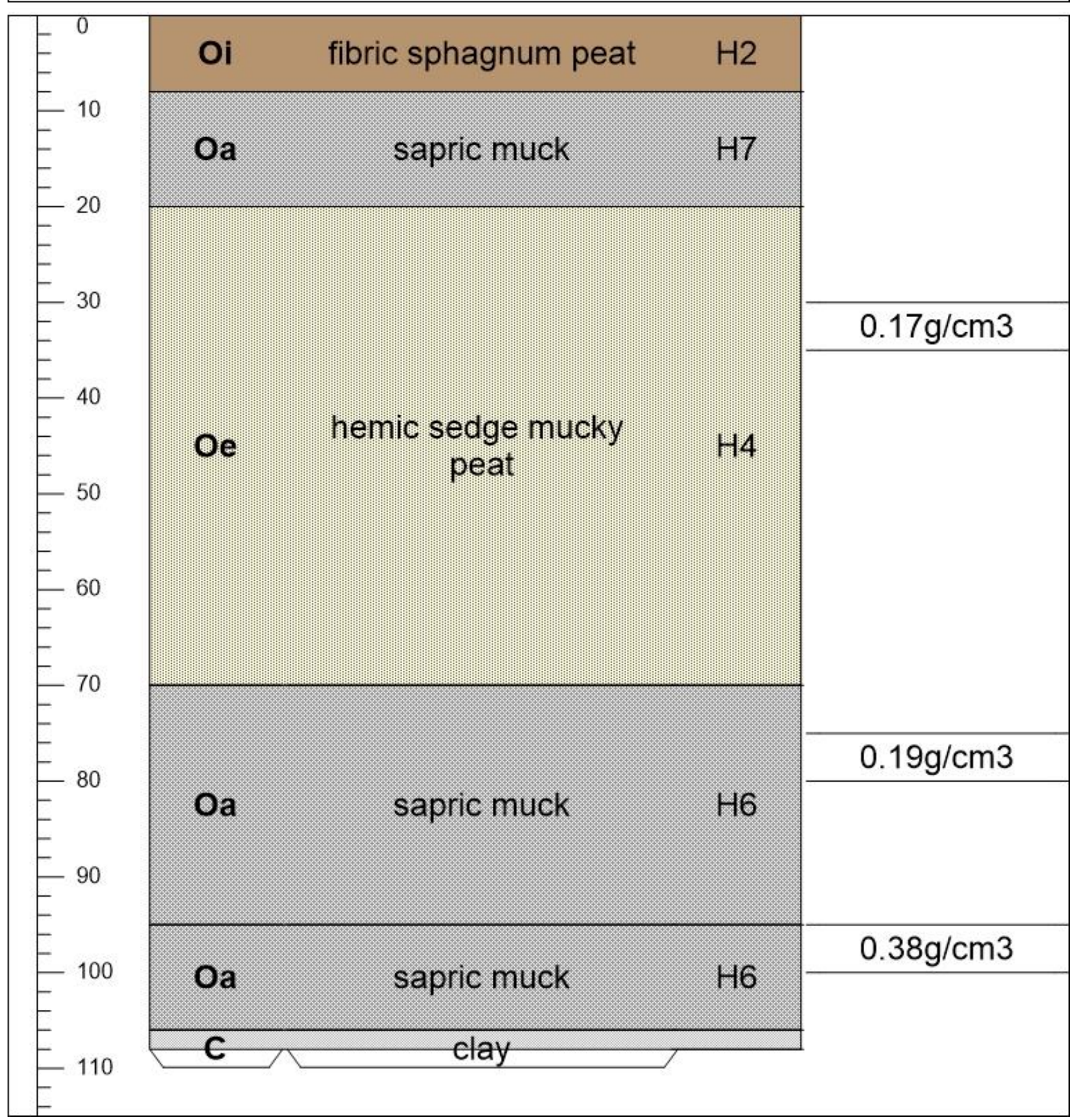

Figure 3-11. Soil profile of Core 3.17, representing Type E (HS) profiles. 


\section{Discussion}

Peatlands formed after the LGM hold a pedomemory of latest Pleistocene and Holocene climatic fluctuations (Booth, 2010; Zaretskaya et al., 2013). This study begins reconstruction of Central Appalachian paleoclimate through peat stratigraphy which is the characterization of the peat horizonation of Histosols that reveal the peatland surface wetness dynamics within CVNWR. A key observation for this reconstruction is the fact that sapric horizons are considered indicative of drier warmer conditions; whereas hemic horizons are associated with wetter cooler conditions (Blackford, 2000; Wieder et al., 2009). When drained, fibric and hemic materials decompose to form sapric materials (Soil Survey Staff, 1999). Warmer temperatures generally increase rates of plant matter decomposition. Humification data indicate changes in the time span from the time of the plant death to the deceased plant matter being incorporated into the anaerobic catotelm (Blackford, 2000). Plant matter decomposition rates sharply decrease in the catotelm, and become independent of all but the most extreme climatic fluctuations (Clymo, 1984, Yu et al., 2003). A lowered water table would expose previously buried peat to aerobic conditions, adjusting the acrotelm-catotelm boundary, exposing hemic material formerly in the catotelm to aerobic conditions and secondary decomposition (Tipping, 1995; Borgmark and Schoning, 2006). Climate influences water table depth, which determines whether organic soil material will accumulate rapidly, accumulate slowly, not accumulate, or decompose. A lowered water table could result from a warmer, drier climate, and therefore increase decomposition of peat formerly preserved within the catotelm. Thus, Histosol horizons represent a proxy for water table position at the time of deposition and thereafter (Blackford, 2000). While peat humification is aided by other paleoclimate proxies to reconstruct past climates (Castro et al., 2015), the abundance of observations within this investigation adds 
breadth to existing regional and local peat paleoclimate reconstructions and provides new data useful to assess synchronization of observed paleoclimate data within the region (Chapter 2).

The mid-Holocene Northgrippian Age, defined as 8,236 to 4,250 cal yr BP (Walker et al., 2012; Cohen et al., 2013; Head and Gibbard, 2015), was characterized in North America by a rapid rise in temperature, with the maximum warmth, the mid-Holocene Climatic Optimum, for which records indicate varied in onset and conclusion from region to region (Viau et al., 2006; Zhao et al., 2010; Shuman and Marsicek, 2016). The Climatic Optimum saw climactic conditions considerably warmer than today (Fairbridge, 1982; Beget, 1983; Driese et al., 2005; Springer et al., 2009; Mullins et al., 2011; Wanner et al., 2014); however, evidence from the eastern North America suggests significant regional variability of moisture associated with that warmth (Barber et al., 1999; Clarke et al., 2003; Viau et al., 2006; Newby et al., 2014). Isotopic analysis of soil organic matter from eastern Pennsylvania, North Carolina, and Tennessee and microscopic charcoal from lake sediments in Tennessee suggest warm, dry conditions during the mid-Holocene Climatic Optimum (Driese et al., 2008; Stinchcomb et al., 2013; Tanner et al., 2015; Ballard et al., 2016).

The warm and dry signature of the Climatic Optimum has been identified in the central Appalachian region. Watts (1979) found that the paleo-vegetation of central Appalachia indicated mid-Holocene water tables were lower or less stable than today. Springer et al. (2009) found evidence of a mid-Holocene warm climate in southeastern West Virginia in stable isotopes of stalagmites and clastic cave sediments. Driese et al. (2005) found mid-Holocene warm and dry climatic conditions accelerated weathering of previously deposited fluvial gravel deposits in southeastern West Virginia. The mid-Holocene Northgrippian Age ended with a pronounced climatic event at 4,200 cal yr BP that manifested in the mid-continent of North America as a 
widespread and severe drought (Booth et al., 2005; Williams et al., 2011; Booth et al., 2012;

Walker et al., 2012; Cohen et al., 2013; Shuman and Marsicek, 2016).

Microtopography and hydrology of peatland surfaces and edaphic hydrology are irregular and dynamic (Ammann et al., 2013; Clymo, 1984; Holden, 2005) and are presumably the reason for the initiation of peat accumulation in the late Northgrippian Age as displayed in the Type A (H) soil profiles. Decomposition during the mid-Holocene Climatic Optimum in these specific locations may have been so great, resulting from a drastically lowered water table, that the earlier deposited peat may have decomposed completely not leaving behind a remnant sapric horizon as in the Type E (HS) soil profile scenario (Figure 3-6). Observations of Peatland 4 during this field investigation did include both small ponds and localized depressional areas with no surface vegetation and an absent acrotelm. As in Type $\mathrm{C}$ and $\mathrm{E}$ profiles, Type $\mathrm{A}(\mathrm{H})$ soil profiles do exhibit the rapid peat accumulation in the middle Meghalayan Age represented by a hemic horizon within the catotelm.

Type B (SH) soil profiles, as represented by Core 1.86 (Figure 3-8), show rapid peat accumulation in the late Pleistocene, corresponding to the catotelm hemic soil materials in these soil profiles (Figure 3-6). As the local climate of the early Holocene Greenlandian Age continued to warm, peat continued to slowly accumulate, followed by even slower peat accumulation during the mid-Holocene Northgrippian Age represented as a sapric horizon spanning the Greenlandian Age to the middle Meghalayan Age. This is consistent with a dryer mid-Holocene Climatic Optimum resulting in a lowered water table. However, Type B (SH) soil profiles do not show the late Meghalayan Age hemic horizon of rapid peat accumulation found in Type $\mathrm{C}(\mathrm{HSH})$ and $\mathrm{E}$ (HS) soil profiles. It is possible that the hydrology of Peatland 1, where most Type B (SH) soil profiles are located, changed during the Northgrippian Age, possibly 
because of local channel incision or differential level development affecting peatland surface wetness. Without a return of the wetter, high-groundwater conditions, these locations did not develop a hemic horizon at the soil surface.

Type C (HSH) soil profiles within CVNWR contain a pedomemory of a wet-dry-wet sequence for local post LGM climate (Figure 3-6), which is supported by radiocarbon dates taken from these cores and concurs with other central Appalachian paleoclimate records. Type C (HSH) soil profiles, as represented by Core 5.17 (Figure 3-9), record late Pleistocene peat deposition in the catotelm as a hemic horizon. Peat accumulated at a slower rate during the early Holocene Greenlandian Age. However, during the Northgrippian Age, peat accumulation slowed drastically, likely in response to a lowered water table under a relatively dry climate. The sapric horizon in the Type C (HSH) soil profiles spans the Greenlandian, Northgrippian, and early Meghalayan ages. The hemic horizon deposited above this sapric material in Type $\mathrm{C}$ (HSH) soil profiles is associated with renewed peat accumulation in the middle and late Meghalayan Age, indicating a wetter local climate with a raised water table following the midHolocene Climatic Optimum.

Type D (S) soil profiles are shallow and primarily located along the edges of the peatlands where water table depths fluctuate the greatest, exposing the catotelm frequently to aerobic conditions and promoting decomposition. Because of their dryer setting and lack of radiocarbon dates these Histosols cannot be used to infer climate.

Although no Type E (HS) soil profiles have radiocarbon dates, the pattern is consistent with Northgrippian Age low peat accumulation, where peatland surface wetness was reduced so greatly in these generally shallow areas that secondary decomposition altered most of the previously deposited hemic material and is now represented as sapric material (Figure 3-6). 
More hemic material was deposited into the catotelm late in peat development, possibly because climatic moisture increased in the Meghalayan Age resulting in a raised water table.

\section{Conclusions}

Using peat stratigraphy and well-dated soil profiles we have found proxy evidence of a dryer local climate during the mid-Holocene Climatic Optimum in the central Appalachian Mountains. Correlating the calibrated radiocarbon dates with the soil profile descriptions and laboratory data revealed that the catotelm in the Histosols of CVNWR contains the pedomemory of a climatic change dating to the mid-Holocene Climatic Optimum. The extremely low peat accumulation rate during this time, represented in CVNWR soil profiles as a sapric horizon, most likely results from an increase in decomposition rate of material at the top of the catotelm (Belyea and Warner, 1996) due to a lowered water table associated with a climatic change from cool and wet in the Greenlandian Age to warm and dry during the Northgrippian Age (Figure 36). The pedomemory revealed in the CVNWR soil profiles concurs with other central Appalachian paleoclimate records and also confirms and compliments the existing published literature on regional paleoclimate for the eastern United States. Peat humification and peat stratigraphy are useful proxy paleoclimate records; understanding how these ecosystems have responded to past climatic changes will help land use managers interpret how these ecosystems might respond to projected future climate change. 


\section{References}

Ammann, B., van Leeuwen, J. F. N., van der Knaap, P., Colombaroli, D., Tinner, W., Wright, H. E., Stefanova, V., 2013. The role of peat decomposition in patterned mires: a case study from the central Swiss Alps. Preslia, 85 (3), 317-332.

Ballard, J.P., Horn, S.P., Li, Z., 2016. A 23,000-year microscopic charcoal record from Anderson Pond, Tennessee, USA. Palynology, 41 (2), 216-229.

Barber, D.C., Dyke, A., Hillaire-Marcel, C., Jennings, A.E., Andrews, J.T., Kerwin, M.W., Bilodeau, G., McNeely, R., Southon, J., Morehead, M. D., Gagnon, J.-M., 1999. Forcing of the cold event of 8,200 years ago by catastrophic drainage of Laurentide lakes. Nature, 400 (6742), 344-348.

Barber, K.E., 1981. Peat stratigraphy and climate change: A palaeoecological test of the theory of cyclic peat bog regeneration. A.A. Balkema, Rotterdam. 242 p.

Barber, K.E., Chambers, F.M., Maddy, D., 2003. Holocene paleoclimates from peat stratigraphy: macrofossil proxy climate records from three ocean raised bogs in England and Ireland. Quaternary Science Reviews, 22 (5-7), 521-539.

Beget, J. E., 1983. Radiocarbon-dated evidence of worldwide early Holocene climate change. Geology, 11 (7), 389.

Belyea, L.R., Warner, B.G., 1996. Temporal scale and the accumulation of peat in a Sphagnum bog. Canadian Journal of Botany, 74 (3), 366-377.

Blackford, J., 2000. Paleoclimatic records from peat bogs. Tree, 15 (5), 193-198.

Boelter, D.H. 1968. Important physical properties of peat materials. In: Proceedings, third international peat congress; 1968 August 18-23; Quebec, Canada: Department of Energy, Minds and Resources and National Research Council of Canada, 150-154.

Booth, R.K., Jackson, S.T., Forman, S.L., Kutzbach, J.E., Bettis III, E.A., Kreig, J., Wright, D.K., 2005. A severe centennial-scale drought in mid-continental North America 4200 years ago and apparent global linkages. The Holocene, 15 (3), 321-328.

Booth, R.K., 2010. Testing the climate sensitivity of peat-based paleoclimate reconstructions in mid-continental North America. Quaternary Science Reviews, 29 (5-6), 720-731.

Booth, R.K., Brewer, S., Blaauw, M., Minckley, T.A., Jackson, S.T., 2012. Decomposing the mid-Holocene Tsuga decline in eastern North America. Ecology, 93 (8), 1841-1852. 
Borgmark, A., Schoning, K., 2006. A comparative study of peat proxies from two eastern central Swedish bogs and their relation to meteorological data. Journal of Quaternary Science, 21 (2), 109-114.

Borren, W., Bleuten, W., Lapshina, E. D., 2004. Holocene peat and carbon accumulation rates in the southern taiga of western Siberia. Quaternary Research, 61 (1), 42-51.

Bronk Ramsey, C., 2009. Bayesian analysis of radiocarbon dates. Radiocarbon, 51 (1), 337360 .

Buol, S.W., Hole, F.D., McCracken, R.J., Southard, R.J., 1997. Soil Genesis and Classification, Fourth Edition, Iowa State University Press, Ames. 527 p.

Byers, E. A., Vanderhorst, J. P., Streets, B. P., 2007. Classification and Conservation Assessment of High Elevation Wetland Communities in the Allegheny Mountains of West Virginia. West Virginia Natural Heritage Program, WV Division of Natural Resources, Wildlife Resources Section, Elkins, West Virginia, 547 p. http://www.wvdnr.gov/publications/PDFFiles/High\%20Allegheny\%20Wetlands-web.pdf (accessed March 2013).

Cameron, C. C., 1970. Peat resources of the unglaciated uplands along the Allegheny structural front in West Virginia, Maryland, and Pennsylvania. Geologic Survey Research 1970, Chapter D: U.S. Geological Survey Professional Paper 700-D, 153-161.

Carlisle, S.C, Mount, H.R., Brown, J.H., 1998. The Mechanics of Soil Survey. Natural Resource Conservation Service, U.S. Department of Agriculture. Lincoln, Nebraska, 38 p.

Castro, D., Souto, M., Garcia-Rodeja, E., Pontevedra-Pombal, X., Fraga, M.I., 2015. Climate change records between the mid- and late Holocene in a peat bog from Serra do Xistral (SW Europe) using plant macrofossils and peat humification analyses. Palaeogeography, Palaeoclimatology, Palaeoecology, 420, 82-95.

Chambers, F.M., Beilman, D.W., Yu, Z., 2010. Methods for determining peat humification and for quantifying peat bulk density, organic matter and carbon content for palaeostudies of climate and peatland carbon dynamics. Mires and Peat, 7 (7), 1-10.

Charman, D.J., Barber, K.E., Blaauw, M., Langdon, P.G., Mauquoy, D., Daley, T.J., Hughes, P.D.M., Karofeld, E., 2009. Climate drivers for peatland paleoclimate records. Quaternary Science Reviews, 28 (19), 1811-1819.

Charman, D.J., Amesbury, M.J., Hinchliffe, W., T.J., Hughes, Mallon, G., Blake, W.H., Daley, P.D.M., Gallego-Sala, A.V., Mauquoy, D., 2015. Drivers of Holocene peatland carbon 
accumulation across a climate gradient in northeastern North America. Quaternary Science Reviews, 121, 110-119.

Clark M. G., Ciolkosz, E. J., 1988. Periglacial geomorphology of the Appalachian highlands and interior highlands south of the glacial border - A review. Geomorphology, 1 (3), 191-220.

Clarke, G., Leverington, D., Teller, J., Dyke, A., 2003. Superlakes, megafloods, and abrupt climate change. Science, 301 (5635), 922-923.

Clymo, R. S., 1984. The limits to peat bog growth. Philosophical Transactions of the Royal Society of London. Series B, Biological Sciences, 303 (1117), 605-654.

Cohen, K.M., Finney, S.C., Gibbard, P.L., Fan, J.-X., 2013; updated. The ICS International Chronostratigraphic Chart. Episodes 36 (3), 199-204.

Daley, T.J., Barber, K.E., Hughes, P.D.M., Loader, N.J., Leuenberger, M., Street-Perrott, F.A., 2016. The 8.2-ka BP event in north-eastern North America: first combined oxygen and hydrogen isotopic data from peat in Newfoundland. Journal of Quaternary Science, 3 (4), 416425 .

Daniels, R.B., Hammer, R.D., 1992. Soil Geomorphology: New York, John Wiley \& Sons, Inc., $236 \mathrm{p}$.

Delcourt, H., Delcourt, P., 1987. Late Quaternary vegetational history in the central Atlantic States. In McDonald, J. N., Bird, S. O. (eds.), The Quaternary of Virginia - a Proceedings Volume: Virginia Division of Mineral Resources Publication 75, 23-35.

Delcourt, H., Delcourt, P., 1988. Quaternary landscape ecology: relevant scales in space and time. Landscape Ecology, 2 (1), 23-44.

De Vleeschouwer, F., Chambers, F.M., Swindles, G.T., 2010. Coring and sub-sampling of peatlands for palaeoenvironmental research. Mires and Peat, 7, Article 1.

Driese, S. G., Li, Z., Horn, S. P., 2005. Late Pleistocene and Holocene climate and geomorphic histories as interpreted from a $23,000{ }^{14} \mathrm{C}$ yr B.P. paleosol and floodplain soils, southeastern West Virginia, USA. Quaternary Research, 63 (2), 136-149.

Driese, S.G., Li, Z.H., McKay, L.D., 2008. Evidence for multiple, episodic, mid-Holocene Hypsithermal recorded in two soil profiles along an alluvial floodplain catena, southeastern Tennessee, USA. Quaternary Research, 69 (2), 276-291. 
Evans, M.G., Warburton, J., 2010. Peatland geomorphology and carbon cycling. Geography Compass, 4 (10): 1513-31.

Fairbridge R.W., 1982. Hypsithermal. In: Beaches and Coastal Geology. Encyclopedia of Earth Science. Springer, Boston, MA.

Fenneman, N.M., Johnson, D.W., 1946. Physiographic Divisions of the United States. U.S. Geological Survey, Washington D.C.

French, H., Millar, S., 2014. Permafrost at the time of the Last Glacial Maximum (LGM) in North America. Boreas, 43 (3), 667-677.

Fortney, R. H., Rentch, J. S., 2003. Post logging era plant successional trends and geospatial vegetation patterns in Canaan Valley, West Virginia, 1945 to 2000. Castanea, 68 (4), 317-334.

Frolking, S., Roulet, N. T., Moore, T. R., Richard, P. J. H., Lavoie, M., Muller, S. D., 2001. Modeling northern peatland decomposition and peat accumulation. Ecosystems, 4 (5), 479-498.

Gałka, M., Swindles, G., Szal, M., Fulweber, R., Feurdean, A., 2018. Response of plant communities to climate change during the late Holocene: Palaeoecological insights from peatlands in the Alaskan Arctic. Ecological Indicators, 85, 525-536.

Gao, J., Ouyang, H., Wang, G., Xu, X., 2010. Recent peat accumulation rates in Zoige peatlands, eastern Tibet, inferred by $210 \mathrm{~Pb}$ and $137 \mathrm{Cs}$ radiometric techniques. Procedia Environmental Sciences, 2, 1927-1933.

Givelet, N., Le Roux, G., Cheburkin, A., Chen, B., Frank, J., Goodsite, M.E., Kempter, H., Krachler, M., Nørnberg, T., Rausch, N., Rheinberger, S., Roos-Barraclough, F., Sapkota, A., Scholz, C., Shotyk, W., 2004. Suggested protocol for collecting, handling and preparing peat cores and peat samples for physical, chemical, mineralogical and isotopic analyses. Journal of Environmental Monitoring, 6 (4), 1464-0325.

Gunnarson, B., Borgmark, A., Wasteård, S., 2003. Holocene humidity fluctuations in Sweden inferred from dendrochronology and peat stratigraphy. Boreas, 32 (2), 347-360.

Halsey, L A., Vitt, D. H., Gignac, L. D., 2000. Sphagnum-dominated peatlands in North America since the Last Glacial Maximum: their occurrence and extent. The Bryologist, 103 (2), 334-352.

Head, M.J., Gibbard, P.L., 2015. Formal subdivisions of the Quaternary System/Period: Past, present, and future. Quaternary International, 383, 4-35. 
Heath, S.L, Loope, H.M., Curry, B.B., Lowell, T.V., 2018. Pattern of southern Laurentide Ice Sheet margin position changes during Heinrich Stadials 2 and 1. Quaternary Science Reviews, $201,362-379$.

Holden, J., 2005. Peatland hydrology and carbon release: why small-scale process matters. Philosophical Transactions of the Royal Society A, Mathematical, Physical and Engineering Sciences, 363 (1837), 2891-2913.

Hou, J., Huang, Y., Shuman, B.N., Oswald, W.W., Foster, D.R., 2011. Abrupt cooling repeatedly punctuated early-Holocene climate in eastern North America. The Holocene, 22 (5), 525-529.

Ingham, M. E., 1996. The bog region of the Allegheny Mountains of West Virginia. Tampa, Florida: University of South Florida. M.A. thesis, 172 p.

Jackson, S.T., Webb, R.S., Anderson, K.H., Overpeck, J. T., Webb III, T., Williams, J. W., Hansen, B., 2000. Vegetation and environment in Eastern North America during the Last Glacial Maximum. Quaternary Science Reviews, 19 (6), 489-508.

Kalnina, L., Stivrins, N., Kuske, E., Ozola, I., Pujate, A., Zeimule, S., Grudzinska, I., Ratniece, V., 2015. Peat Stratigraphy and Changes in Peat Formation during the Holocene in Latvia. Quaternary International, 383 (2), 186-95.

Keys, D., Henderson, R.E., 1983. Field and Data Compilation Methods Used in the Inventory of the Peatlands of New Brunswick, Canada. In Jarrett, P.M. (ed.), Testing of Peats and Organic Soils, 55-71.

Klemetti, V., Keys, D., 1983. Relationships between Dry Density, Moisture Content, and Decomposition of Some New Brunswick Peats. In Jarrett, P.M. (ed.) Testing of Peats and Organic Soils, 72-82.

Kneller, M., Peteet, D., 1993. Late-Quaternary climate in the Ridge and Valley of Virginia, U.S.A.: Changes in vegetation and depositional environment: A contribution to the 'North Atlantic seaboard programme' of IGCP-253, 'Termination of the Pleistocene'. Quaternary Science Reviews, 12 (8), 613-628.

Kost, M.A., Albert, D.A., Cohen, J.G., Slaughter, B.S., Schillo, R.K., Weber, C.R., Chapman, K.A., 2007. Natural communities of Michigan: classification and description. Michigan Natural Features Inventory, Report No. 2007-21, Lansing, MI. 
Langdon, P.G, Brown, A.G., Caseldine, C.J., Blockley, S.P.E., Stuijts, I., 2012. Regional climate change from peat stratigraphy for the mid- to late Holocene in central Ireland. Quaternary International, 268, 145-155.

Larabee, P.A., 1986. Late-Quaternary vegetational and geomorphic history of the Allegheny Plateau at Big Run Bog, Tucker County, West Virginia. The University of Tennessee, Knoxville. M.S. thesis, 116 p.

Lee, G.B., Manoch, B., 1974. Macromorphology and micromorphology of a Wisconsin saprist. In Aandahl, A.R., Boul, S.W., Hill, D.E., Bailey, H.H. (eds.) Histosols: Their characteristics, classification, and use. Soil Science Society of America Special Publication 6, Madison Wisconsin, 47-62.

Li, Y., Yu, Z., Kodama, K.P., 2007. Sensitive moisture response to Holocene millennial-scale climate variations in the mid-Atlantic region, USA. The Holocene, 17 (1), 3-8.

Lin, H., 2011. Three principles of soil change and pedogenesis in time and space. Soil Science Society of America Journal, 75 (6), 2049-2070.

Losche, C.K., Beverage, W.W., 1967. Soil Survey of Tucker County and part of northern Randolph County, West Virginia: Washington, D.C., U.S. Department of Agriculture, Soil Conservation Service, $78 \mathrm{p}$.

Lowell, T. V., Savage, K. M., Brockman, C. S., Stuckenrath, R., 1990. Radiocarbon analysis from Cincinnati, Ohio and their implications for glacial stratigraphic interpretations. Quaternary Research, 34 (1), 1-11.

Malterer, T., 2014. Personal communication to Mitzy Schaney during a field instructional session, May 20, 2014 in Baraga, Michigan.

Matchen, D.L., Fedorko, N., Blake, Jr., B.M., 1999. Geology of Canaan Valley, West Virginia Geological and Economic Survey Open File Publication, OF-9902.

Matchen, D. L., 2015. The geology of Canaan Valley. Southeastern Naturalist, 14 (7), 7-17.

Morris, P., Swindles, P., Valdes, P., Ivanovic, R., Gregoire, L., Smith, M., Tarasov, L., Haywood, A., Bacon, K., 2018. Global peatland initiation driven by regionally asynchronous warming. Proceedings of the National Academy of Sciences, 115 (19), 4851-4856.

Mullins, H.T., Patterson, W.P., Teece, M.A., Burnett, A.W., 2011. Holocene climate and environmental change in central New York. Journal of Paleolimnology, 45 (2), 243-256. 
Nauman, T.W., Thompson, J.A., Teets, S. J., Dilliplane, T.A., Bell, J.W., Connolly, S.J., Liebermann, H.J., Yoast, K.M., 2015. Ghosts of the forest: Mapping pedomemory to guide forest restoration. Geoderma, 247-248 (6), 51-64.

Nelson, K., Nelson, F., Walegur, M., 2007. Periglacial Appalachia: palaeoclimatic significance of blockfield elevation gradients, eastern USA. Permafrost and Periglacial Processes, 18, 61-73.

Newby, P.E., Shuman, B.N., Donnelly, J.P., Karnauskas, K.B., Marsicek, J., 2014. Centennialto-millennial hydrologic trends and variability along the North Atlantic Coast, USA, during the Holocene. Geophysical Research Letters, 41 (12), 4300-4307.

Ovenden, L., 1990. Peat accumulation in northern wetlands. Quaternary Research, 33 (3), 377386.

Piotrowska, N., Blaauw, M., Mauquoy, D., Chambers, F.M., 2010. Constructing deposition chronologies for peat deposits using radiocarbon dating. Mires and Peat, 7, article 10, 1-14. http://www.mires-and-peat.net/, ISSN 1819-754X @ 2011 International Mire Conservation Group and International Peat Society.

Reger, J., Cleaves, E., 2008. Physiographic map of Maryland. Maryland Geological Survey, Baltimore, Maryland.

Reimer, P. J., Bard, E., Bayliss, A., Beck, J. W., Blackwell, P. G., Bronk Ramsey, C., Grootes, P. M., Guilderson, T. P., Haflidason, H., Hajdas, I., HattŽ, C., Heaton, T. J., Hoffmann, D. L., Hogg, A. G., Hughen, K. A., Kaiser, K. F., Kromer, B., Manning, S. W., Niu, M., Reimer, R. W., Richards, D. A., Scott, E. M., Southon, J. R., Staff, R. A., Turney, C. S. M., van der Plicht, J., 2013. IntCal13 and Marine13 radiocarbon age calibration curves 0-50,000 years cal BP.

Radiocarbon, 55 (4), 1869-1887.

Rigg, G. B., Strausbaugh, P. D., 1949. Some stages in the development of sphagnum bogs in West Virginia. Castanea, 14 (4), 129-148.

Schaney, C.R., Schaney, M.L., in preparation. Assessing the impact of anthropogenic activities in peatlands of Canaan Valley National Wildlife Refuge.

Schoeneberger, P.J., Wysocki, D.A., Benham, E.C., Soil Survey Staff, 2012. Field book for describing and sampling soils, Version 3.0. Natural Resources Conservation Service, National Soil Survey Center, Lincoln, NE, 263 p.

Sevon, W., 2018. Physiographic provinces of Pennsylvania. Commonwealth of Pennsylvania Department of Conservation and Natural Resources, Bureau of Topographic and Geologic Survey, Harrisburg, Pennsylvania. 
Shuman, B.N., Marsicek, J., 2016. The structure of Holocene climate change in mid-latitude North America. Quaternary Science Reviews, 141, 38-51.

Smith, R., Michalyna, W., Eilers, R., Fraser, W., Veldhuis, H., St. Jacques, E., Swidinsky, D., Mills, G., Hopkins, L., Podolsky, G., Aglugub, C., Podolsky, I.G., Haluschak, P., Griffiths, J., Erb, M., Cyr, P., 2007. Manual for Describing Soils in the Field - Revised 2007, Manitoba Land Resource Unit, Agriculture and Agri-Food Canada and Soil Resource Section, Manitoba Agriculture, $79 \mathrm{p}$.

Soil Survey Staff, 1999. Soil Taxonomy: A basic system of soil classification for making and interpreting soil surveys. 2nd edition. Natural Resources Conservation Service. U.S. Department of Agriculture Handbook, 436 p.

Soil Survey Staff, 2010. Keys to Soil Taxonomy, $11^{\text {th }}$ Edition. U.S. Department of Agriculture, Natural Resources Conservation Service, 346 p.

Soil Survey Staff, 2014. Soil Survey Field and Laboratory Methods Manual. Soil Survey Investigations Report No. 51, Version 2.0. R. Burt and Soil Survey Staff (eds.). U.S. Department of Agriculture, Natural Resources Conservation Service, $530 \mathrm{p}$.

Soil Survey Staff, 2014. Kellogg Soil Survey Laboratory Methods Manual. Soil Survey Investigations Report No. 42, Version 5.0. R. Burt and Soil Survey Staff (ed.). U.S. Department of Agriculture, Natural Resources Conservation Service, 1031 p.

Springer, G.S., Rowe, H.D., Hardt, B., Cocina, F.G., Edwards, R. L., Cheng, H., 2009. Climate driven changes in river channel morphology and base level during the Holocene and late Pleistocene of southeastern West Virginia. Journal of Cave and Karst Studies, 71 (2), 121-129.

Stinchcomb, G.E., Messner, T.C., Williamson, F.C., Driese, S.G., Nordt, L.C., 2013. Climatic and human controls on Holocene floodplain vegetation changes in eastern Pennsylvania based on the isotopic composition of soil organic matter. Quaternary Research, 79 (3), 377-390.

Stolt, M.H., Bakken, J., 2014. Inconsistencies in terminology and definitions of organic soil materials. Soil Science Society of America Journal, 78 (4), 1332-1337.

Tanner, B. R., Lane, C. S., Martin, E. M., Young, R., Collins, B., 2015. Sedimentary proxy evidence of a mid-Holocene Hypsithermal event in the location of a current warming hole, North Carolina, USA. Quaternary Research, 83 (2), 315-323.

Targulian, V.O., Goryachkin, S.V., 2004. Soil memory: Types of record, carriers, hierarchy and diversity. Revista Mexicana de Ciencias Geológicas, 21 (1), 1-8. 
Tipping, R., 1995. Holocene evolution of a lowland Scottish landscape: Kirkpatrick Fleming. Part I, peat- and pollen-stratigraphic evidence for raised moss development and climatic change. The Holocene, 5 (1), 69-81.

Tuittila, E., Juutinen, S. Frolking, S., Väliranta, M., Laine, A. M., Miettinen, A., Seväkivi, M., Quillet, A., Merilä, P., 2012. Wetland chronosequence as a model of peatland development: Vegetation succession, peat and carbon accumulation. The Holocene, 23 (1), 25-35.

United States Department of Agriculture, Natural Resources Conservation Service, 2010. Field Indicators of Hydric Soils in the United States, Version 7.0. L.M. Vasilas, G.W. Hurt, and C.V Noble (eds.). USDA, NRS, in cooperation with the National Technical Committee for Hydric Soils, $44 \mathrm{p}$.

Verry, E.S., Boelter, D.H., Paivanen, J., Nichols, D.S., Malterer, T., Gafni, A., 2011. Physical properties of organic soils. In Kolka, R.K., Sebestyen, S.D., Verry, E.S., Brooks, K.N. (eds.). Peatland biogeochemistry and watershed hydrology at the Marcell Experimental Forest. Boca Raton, FL, CRC Press, 135-176.

Viau, A.E., Gajewski, K., Sawada, M.C., Fines, P., 2006. Millennial-scale temperature variations in North America during the Holocene. Journal of Geophysical Research, 111 (D9), $1-12$.

Vitt, D. H., 2006. Bryophyte Community Ecology: Going Beyond Description. Lindbergia, 31 (1), 33-41.

Vitt, D. H., Wieder. R. K., 2006. Boreal peatland ecosystems: our carbon heritage. Ecological Studies: Analysis and Synthesis 188, 425-30.

Vitt, D. H., Wieder, R. K., Scott, K. D., Faller, S., 2009. Decomposition and peat accumulation in rich fens of boreal Alberta, Canada. Ecosystems, 12 (3), 360-373.

von Post, L., 1924. Das genetische System der organogenen Bildung Schwedend. In: quatrieme Commission, Commission pour la Nomenclature et la classifications des sols. Comite Internationale de Pedologie. IV Commission No. 2, Rome, 287-304.

Walbridge, M. R., 1994. Plant community composition and surface water chemistry of fen peatlands in West Virginia's Appalachian plateau. Water, Air, and Soil Pollution, 77 (3-4), 247269.

Walker, M.J.C., Berkelhammer, M., Björck, S., Cwynar, L.C., Fisher, D.A., Long, A.J., Lowe, J.J., Newnham, R.M., Rasmussen, S.O., Weiss, H., 2012. Formal subdivision of the Holocene Series/Epoch: a discussion paper by a Working Group of INTIMATE (Integration of ice-core 
marine and terrestrial records) and the Subcommission on Quaternary Stratigraphy (International Commission on Stratigraphy). Journal of Quaternary Science 27 (7), 649-659.

Walker, M., Head, M.J., Berkelhammer, M., Björck, S., Cheng, H., Cwynar, L., Fisher, D., Gkinis, V., Long, A., Lowe, J., Newnham, R., Rasmussen, S.O., Weiss, H., 2018. Formal ratification of the subdivision of the Holocene Series/Epoch (Quaternary System/Period): two new Global Boundary Stratotype Sections and Points (GSSPs) and three new stages/subseries. Episodes, 41 (4), 213-223.

Wanner, H., Mercolli, L., Grosjean, M., Ritz, S.P., 2015. Holocene climate variability and change; a data-based review. Journal of the Geological Society, 172 (2), 254-263.

Watts, W. A., 1979. Late Quaternary vegetation of central Appalachia and the New Jersey coastal plain. Ecological Monographs, 49 (4), 427-469.

Webb, R. S., Anderson, K. H., Webb III, T., 1993. Pollen response-surface estimates of latequaternary changes in the moisture balance of the northeastern United States. Quaternary Research, 40 (2), 213-227.

West Virginia Geologic and Economic Survey, 2017. Physiographic provinces of West Virginia. West Virginia Geologic and Economic Survey, Morgantown, West Virginia.

Wieder, R.K., Turetsky, M.R., Vile, M.A., 2009. Peat as an archive of atmospheric, climatic and environmental conditions. In Maltby, E., Barker, T. (eds.). The Wetlands Handbook, 96-112. Blackwell Publishing.

Wieder, R.K., Vitt, D.H., (eds.), 2006. Boreal Peatland Ecosystems, Ecological Studies 188, Springer-Verlang, Berlin, Heidelberg, 436 p.

Willard, D., Bernhardt, C., Korejwo, D., Meyers, S., 2005. Impact of millennial-scale Holocene climate variability on eastern North American terrestrial ecosystems: pollen-based climatic reconstruction. Global and Planetary Change, 47 (1), 17-35.

Williams, J.W., Blois, J.L., Shuman, B.N., 2011. Extrinsic and Intrinsic forcing of abrupt ecological change: case studies from the late Quaternary. Journal of Ecology, 99 (3), 664-677.

Yu, Z., 2007. Rapid response of forested vegetation to multiple climatic oscillations during the last deglaciation in the northeastern United States. Quaternary Research, 67 (2), 297-303.

Yu, Z., Vitt, D.H, Campbell, I.D, Apps, M.J., 2003. Understanding Holocene peat accumulation pattern of continental fens in western Canada. Canadian Journal of Botany, 81 (3), 267-282. 
Yu, Z., Beilman, D.W., Jones, M.C., 2009. Sensitivity of northern peatland carbon dynamics to Holocene climate change. Geophysical Monograph Series 184, 55-69.

Zaretskaya, N.E., Panova, N.K., Antipina, T.G., Zhilin, M.G., Uspenskaya, O.N., Savchenko, S.N., 2013. Geochronology, stratigraphy, and evolution of Middle Uralian peatlands during the Holocene (exemplified by the Shigir and Gorbunovo peat bogs). Stratigraphy and Geological Correlation, 22 (6), 632-654.

Zhao, C., Yu, Z., Ito, E.., Zhao Y., 2010. Holocene climate trend, variability, and shift documented by lacustrine stable-isotope record in the northeastern United States. Quaternary Science Reviews, 29 (15-16), 1831-1843. 


\title{
Chapter 4
}

\section{Classification and Mapping of Rare and Unique Histosols in the Central Appalachian Peatlands of Canaan Valley National Wildlife Refuge, West Virginia}

\author{
Mitzy L. Schaney ${ }^{a,}$, James A. Thompson ${ }^{b}$, J. Steven Kite ${ }^{c}$, Christopher R. Schaney ${ }^{d}$ \\ ${ }^{\text {a }}$ Geography Department, University of Pittsburgh at Johnstown, Krebs Hall 108D, 450 \\ Schoolhouse Road, Johnstown, PA 15904 \\ ${ }^{\mathrm{b}}$ Division of Plant and Soil Science, West Virginia University, 3115 Agricultural Sciences \\ Building, 1194 Evansdale Drive, Morgantown, WV 26506-6108 \\ ${ }^{c}$ Department of Geology and Geography, West Virginia University, 330 Brooks Hall, P.O. Box \\ 6300, Morgantown, WV 26506 \\ ${ }^{\mathrm{d}}$ Department of Geography, Indiana University of Pennsylvania, 981 Grant Street, Indiana, PA \\ 15705 \\ *Corresponding author: m.schaney@pitt.edu
}

\begin{abstract}
Canaan Valley in West Virginia contains a greater area of peatlands than any other locality in the mid-Atlantic Highlands. Eighty-eight soil cores in five Canaan Valley National Wildlife Refuge (CVNWR) peatlands were described, sampled, characterized using field and laboratory data, classified according to Soil Taxonomy, and mapped following the NRCS Soil Survey Manual. The most representative Histosols were classified as Dysic, frigid Sapric Haplohemists and assigned a new formal NRCS soil series name of Canaan Valley peat with an official series description. The five peatland landforms now are associated with a new map unit: Canaan Valley peat, moist, 0 to 3 percent slopes (map unit symbol CavA), covering a total of 246 hectares within CVNWR. These rare soils support unique ecosystems of high conservation
\end{abstract}


value that hold a concentration of biodiversity in the eastern United States. These soils also contain a pedomemory of valuable paleoclimatic and paleoenvironmental proxies; the interpretation of which contributes to the regional paleoclimatic and paleoenvironmental body of knowledge. This new mapping, classification, and naming of these Histosols conveys their significance and roles they play as the interface of the lithosphere, biosphere, atmosphere, and hydrosphere within these ecosystems.

\section{Introduction}

Soils are classified to meet several objectives. These include facilitating the organization of knowledge, improving communication among scientists, and promoting a clearer understanding of the relationship soils have to their landforms, ecosystems, and surrounding soils (Buol et al., 1997; Schimel and Chadwick, 2013). The United States Department of Agriculture Natural Resource Conservation Service (USDA-NRCS) maintains the national program for soil mapping and the official soil classification system presented in Soil Taxonomy. Not only does this taxonomic classification facilitate communication with other scientists, but also conveys the soil's morphologic properties (Buol et al., 1997; Schimel and Chadwick, 2013). Soil information is fundamental to site descriptions for ecosystem-scale research and management (Schimel and Chadwick, 2013), and taxonomic information allows us to establish linkages between the results of various studies and observations of soil characteristics. A proper taxonomic classification accurately establishes the presence of diagnostic horizons and features as well as the physical, chemical, and mineralogical properties that are used to interpret a soil's suitabilities and limitations. Each piece of the taxonomic classification offers information and allows inferences to be made, not only about the soil itself, but also about the ecosystem and how it functions (Schimel and Chadwick, 2013). At the most specific level in Soil Taxonomy, the official series 
description is the narrative that designates the horizonation and associated morphological properties of a soil, its geomorphic setting, and its relationship to other known soil series.

Peatlands occupy about $2.7 \%$ of the earth's terrestrial surface, and Histosols are the primary soil order within these peatlands (Chimner et al., 2014; Kolka et al., 2016; Loisel and Garneau, 2010; Yu et al., 2011, 2010; Zauft et al., 2010). Peatlands act as archives of paleoenvironmental and paleoclimatic proxies, serve as both sinks $\left(\mathrm{CO}_{2}\right)$ and sources $\left(\mathrm{CO}_{2}\right.$ and $\mathrm{CH}_{4}$ ) of greenhouse gases, and represent a substantial worldwide carbon pool, making them scientifically valuable to understanding past, current, and future global and local climates (Beilman et al., 2010; Chimner et al., 2014; Franzen et al., 2012; Ireland et al., 2013; Langdon et al., 2012; Loisel and Garneau, 2010; Warren et al., 2012; Yu et al., 2011, 2009; Zauft et al., 2010). Soil is the largest active terrestrial reservoir in the global carbon cycle (Rumpel and Kögel-Knabner, 2011; Rumpel, 2014). Peatlands constitute approximately $30 \%$ of the world's soil carbon (Beilman et al., 2010; Chimner et al., 2014; Franzen et al., 2012; Holden, 2005).

Peatlands form when net primary production of vegetation exceeds decomposition, resulting in accumulation of organic matter and the formation of organic soils (Vitt, 2006; Yu et al., 2009). This process is primarily related to hydroclimatic conditions of abundant moisture and relatively low temperature (Loisel and Garneau, 2010). Globally, peatland occurrence is strongly related to topography and climate (Franzen et al., 2012). Flat topography in boreal climates with abundant moisture and relatively low temperature is particularly conducive to peatland formation; large areas of tropical peatlands also exist due to rapid vegetation growth (Cameron et al., 1989; Dommain et al., 2014; Kolka et al., 2016; Page et al., 2011; Yu et al., 2010). Organic soils are most abundant within two regions of the contiguous United States, the 
upper Midwestern states of Michigan, Minnesota, and Wisconsin; and the Southern states of Florida, Louisiana, and North Carolina (Cameron et al., 1989; Kolka et al., 2016). Histosols are not common in the Appalachian Mountains and no Histosols classified to the soil series level were mapped in West Virginia prior to this research.

High-elevation peatlands of the central Appalachian Mountains are a southern extension of contemporary boreal ecosystems commonly associated with bogs and fens (Francl et al., 2004; Ingham, 1996; Snyder et al., 2006; Stewart and Nilsen, 1993; Stine et al., 2011; Whitehead, 1965). Some central Appalachian geographic niches are similar climatically to numerous northern boreal peatlands (Cameron, 1970), with abundant moisture and relatively low temperature (Sencindiver et al., 2015; Vogel and Leffler, 2015; Walbridge, 1994; Western Regional Climate Center, 2016). Local topography, orographic precipitation, and the frost pocket effect (where cold, dense, nocturnal air drains downslope decreasing valley floor temperatures), all contribute to microclimates supportive of peat accumulation (Byers et al., 2007; Stewart and Nilsen, 1993; Vogel and Leffler, 2015; Walbridge, 1994).

The floor of Canaan Valley contains one of the largest inland freshwater wetland ecosystems of peatlands, marshes, wet meadows, and shrub and forested wetlands in the eastern United States (Fortney and Rentch, 2003). These minerotrophic peatlands are characterized by exceptionally high biodiversity and conservation value (Byers et al., 2007), and have the largest peat deposits located in the unglaciated uplands along the Allegheny structural front in West Virginia, Maryland, and Pennsylvania (Cameron, 1970). Peatlands in the Unglaciated Allegheny Plateau range in size from a few hectares to a few hundred hectares (Ingham, 1996), and are typically situated in geomorphic depressions at higher elevations (above $730 \mathrm{~m}$ ) (Byers et al., 2007; Diehl and Behling, 1982; Ingham, 1996). Byers et al. (2007) placed peatlands within the 
High Allegheny Wetland Ecological System, which contains some of the highest concentrations of globally rare plant and animal species within the northeastern United States (Byers et al., 2007). Loss of any of the few Allegheny Mountain peatlands would compromise regional biodiversity (Walbridge, 1994). The high conservation value of Canaan Valley peatlands and their associated ecosystems originates from a few fundamental factors, including a distinctive biota that stems from their location south of the Last Glacial Maximum ice margin, their complex topography and geology, and their extent as one of the largest inland freshwater wetland ecosystems in the eastern United States (Bartgis et al., 2015; Byers et al., 2007; Fortney and Rentch, 2003; Fortney et al., 2015).

A dynamic component of these distinctive ecosystems in Canaan Valley are the soils that support the rare plant and animal communities. Canaan Valley ecosystems have been extensively studied, named, and classified (Allard and Leonard, 1952; Bartgis et al., 2015; Bonner et al., 2009; Byers et al., 2007; Chadbourne and Anderson, 2015; Core, 1950; Faust and Petersen, 2015; Fortney and Rentch, 2003; Fortney et al., 2015; Grafton and Fortney, 2015; McDonald, 2015; Rentch et al., 2008; Rentch and Anderson, 2000; Snyder et al., 2006). Although the accompanying soils have been briefly examined and discussed (Cameron, 1970; Francl et al., 2004; Sencindiver et al., 2015), a full investigation, mapping, description, and classification of these natural soil bodies was lacking prior to this study. Goals of this research were to characterized, apply soil taxonomy principles to, and classify these previously undescribed natural bodies of soil highlighting the value of classification of these rare and unique Histosols within Canaan Valley National Wildlife Refuge (CVNWR). The naming and consequent taxonomic classification of these natural bodies of soil not only elevate its importance, but also improve communication regarding this soil and the unique ecosystems it 
supports. These efforts were facilitated by working closely and coordinating with NRCS soil scientists to establish a new official series description.

\section{Landscape setting}

The High Allegheny Wetland Ecological System occurs in a southwest-northeast trending band about $40 \mathrm{~km}$ wide and $200 \mathrm{~km}$ long within the Allegheny Mountain section of the Appalachian Plateaus physiographic province in unglaciated Pennsylvania, Maryland, and West Virginia (Byers et al., 2007; Fenneman and Johnson, 1946; Reger and Cleaves, 2008; Sevon, 2018; West Virginia Geologic and Economic Survey, 2017). This physiographic subdivision correlates with the USDA Major Land Recourse Area (MLRA) 127, the Eastern Allegheny Plateau and Mountains (Figure 4-1). In general, the Allegheny Mountain section is higher in elevation than adjacent physiography, and characterized by broad, open structural bedrock folds (Matchen, 2015). Allegheny Mountain peatlands originate in depressions or behind knickpoints in, or near, headwaters of first or second order streams (Byers et al., 2007; Diehl and Behling, 1982; Ingham, 1996; Rigg and Strausbaugh, 1949). Canaan Valley is a high elevation (965-1000 $\mathrm{m})$, breached anticlinal valley; almost the entire valley is drained by the headwaters of Blackwater River, a Cheat River tributary. Surrounding mountain ridges, with elevations of 1,100 to $1,300 \mathrm{~m}$, are capped by resistant Pottsville Sandstone; the more easily erodible valley slopes are formed on Mauch Chunk shale, sandstone, and limestone; whereas most of the valley floor is underlain by Greenbrier Limestone and shaley members of the lower Mauch Chunk (Fortney and Rentch, 2003). Projecting through bottomlands in the valley center is a low, elongate ridge, known as Middle Ridge, which is comprised of coarse-grained sandstone of the Price Formation, exposed along the axis of an anticline (Matchen, 2015). 
Figure 4- 1. Canaan Valley represented by a star, with USDA Major land Resource Area (MLRA) 127 (from NRCS 2006 MLRA Geographic Database, version 4.2) shown shaded in gray.

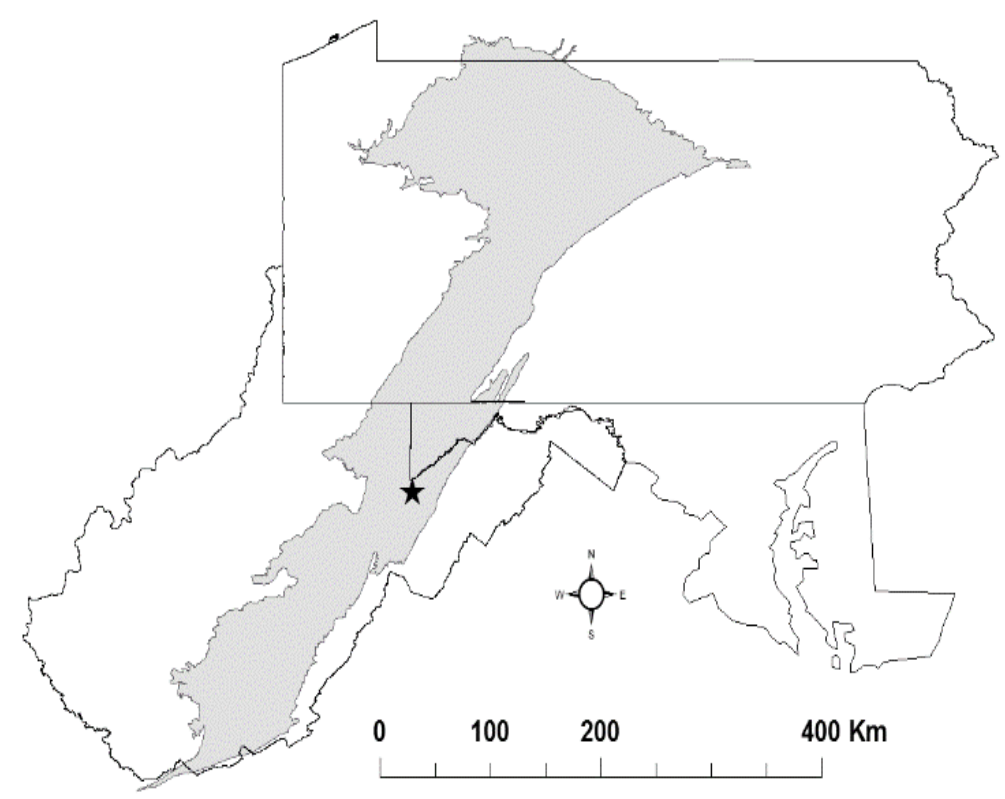

CVNWR encompasses the northern portion of Canaan Valley, protecting most of West Virginia's largest wetland complex. Within this valley, the study areas consist of five interfluve fen landforms. These five landforms were previously mapped as Soil Conservation Service soil map units labeled as muck and peat (Losche and Beverage, 1967). Small-unnamed tributaries of the Blackwater River bordered by Entisols with histic epipedons or hydric components separate these five peatlands (Losche and Beverage, 1967). The five peatlands are classified ecologically as very poor fens: very acidic, moderately influenced by ground water, and dominated by sedges with a continuous carpet of Sphagnum (Kost et al., 2007). They are flood- and beaver-influenced wetlands encompassing shrub swamps, sedge fens, wet meadows, and open marshes (Byers et al., 2007). Forested swamps occupy the slightly higher elevation margins around most of the peatlands. Bryophyte groundcover vegetation in these peatlands commonly consists of Sphagnum rubellum, Sphagnum recurvum, Sphagnum palustre, and Polytrichum commune. Herbaceous vegetation includes Eriophorum virginicum (tawny cottongrass), Rhyncospora alba (white beaksedge), Solidago uliginosa (bog goldenrod), Carex folliculata (northern long sedge), 
and minor amounts of Scirpus sp. (bulrush). Woody shrub vegetation primarily consists of Photinia melanocarpa (black chokeberry), Aronia arbutifolia (red chokeberry), Vaccinium oxycoccos (small cranberry), Ilex verticillata (common winterberry), Hypericum (St. Johnswort), Viburnum nudum (northern wild raisin), Vaccinium myrtilloides (velvetleaf blueberry), and Rubus hispidus (bristly dewberry). Overstory vegetation is sparse, usually isolated on hummocks, and typically comprised of Picea rubens (red spruce), Pinus strobus (white pine), and Abies balsamea (balsam fir).

\section{Methods}

Soils within the five peatlands were described, sampled, characterized using both field and laboratory data, classified, and mapped. Soil mapping, as defined in the Soil Survey Manual is "the process of delineating natural bodies of soils, classifying and grouping the delineated soils into map units, and capturing soil property information for interpreting and depicting soil spatial distribution on a map" (Soil Science Division Staff, 2017). Initial stages of this research were guided by preexisting NRCS muck and peat map unit delineations in CVNWR, which encompassed 187 hectares (Losche and Beverage, 1967). These areas were designated as Peatland 1 through 5 for the purposes of this study. A focus of this research was to determine what types of soils exist within these delineations, and whether the map unit polygon boundaries were accurate.

Soil morphology describes and measures a wide range of soil properties, it deals with form, structure, and organization of the soil materials; it is a record of past and current ecological and geomorphic processes (Daniels and Hammer, 1992). Soil morphology is observed and described in the field and can be augmented with laboratory data. It can provide insight into how ecosystems change (Nauman et al., 2015), basic data for interpreting soil genesis (Buol et al., 
1997), and shed light upon the developmental and climatic history of peatlands (Yu et al., 2009).

Soil morphology was determined by profiling 100 soil cores throughout and around the five

study areas. All profiles were classified based upon the field descriptions using Soil Taxonomy

(Soil Survey Staff, 1999). Thirty of the 100 cores were sampled for laboratory analysis,

including radiocarbon dating, bulk density, loss on ignition, fiber content, and pyrophosphate

color; this data was also included in classification.

$\underline{\text { Field methods }}$

Soil core locations were chosen according to the "free survey" method of sampling soils, which involves the application of soil-landscape concepts based on the premise that soils vary repetitively and predictably with geomorphology, topography, and related factors (Carlisle et al., 1998). Location of cores was representative of the immediately surrounding terrain. Hummocks and hollows were avoided, as were locations of known anthropogenic disturbance. Taking into account vegetation, ecosystem, microtopography, and water depth, a minimum of two individual soil core profile locations within each peatland were sampled for laboratory analysis.

\section{$\underline{\text { Laboratory methods }}$}

CVNWR secured funding through U.S. Fish and Wildlife Service, in conjunction with the Radiocarbon Collaborative, sponsored jointly by the USDA Forest Service, University of California Irvine (previous mass spectrometry conducted at Lawrence Livermore National Lab in Livermore, California), and Michigan Technological University, to provide radiocarbon dating of 52 samples from 11 cores. Radiocarbon dating samples were chosen based on core location within the peatlands and horizon depth within the profile, focusing on basal peat dates, horizon breaks within the catotelm, and sedimentary sequence of the thickest/deepest cores (Givelet et al., 2004; Piotrowska et al., 2010; Tuittila et al., 2012). Standard radiocarbon ages were 
calibrated to dates (cal yr BP) using OxCal 4.2 and IntCal13 Northern Hemisphere calibration curve (Bronk Ramsey, 2009; Reimer et al., 2013).

Bulk density, loss on ignition (LOI), fiber content, and pyrophosphate color laboratory analysis were conducted in the labs of the Division of Plant and Soil Science of West Virginia University. Individual horizons were sampled within each of the 30 cores chosen for laboratory analysis. Laboratory procedures from the Kellogg Soil Survey Laboratory Methods Manual (Soil Survey Staff, 2014) were followed for the laboratory analysis, with the explicit intention of soil classification.

\section{$\underline{\text { Classification }}$}

The Kellogg Soil Survey Laboratory Methods Manual (Soil Survey Staff, 2014) in conjunction with Soil Taxonomy (Soil Survey Staff, 1999) were utilized for classification of the soil profiles described in the field. Field descriptions matched well with laboratory data for horizon designations, but lab data took priority over field descriptions when they differed.

Soil properties necessary for classifying Histosols to the family level of Soil Taxonomy include the thickness of organic soil materials, degree of organic material decomposition, and soil pH (Bakken and Stolt, 2018). However, soil series, not families or higher-level taxa, are the dominant component of most soil map units and, consequently, series are most commonly used as map units in U.S. soil surveys (Soil Science Division Staff, 2017). In order to determine if a new soil series and map unit designation were warranted, soil pedons from this investigation were classified and compared to geographically associated soils series, Histosol soil series mapped within MLRA 127, and the only recognized soil series within the same family. 


\section{Results}

The five map unit polygons, previously mapped as 187 hectares, were remapped as 246 hectares (Table 4-1 and Figure 4-2). Updating these soil map unit polygons was facilitated by the 100 soil cores throughout and around the five study areas. Of these 100 soil profiles, 12 were determined to be Entisols; these were all outside of the peatland landforms and will not be discussed further. The 88 Histosol soil profiles were characterized and classified down to the subgroup level (Table 4-1). Ruts from a late $20^{\text {th }}$ Century off-road vehicle race (Dirt Wheels Magazine, 2018) were still present within all five peatlands; however, these ruts did not disturb the natural bodies of soil below the water table into the catotelm (Schaney and Schaney, in preparation). Remnants of early $20^{\text {th }}$ Century rail beds, a long abandoned logging road, and incised historic logging skids were also present throughout the five peatlands (Schaney and Schaney, in preparation).

\begin{tabular}{|c|c|c|c|c|c|c|}
\hline & Peatland 1 & Peatland 2 & Peatland 3 & Peatland 4 & Peatland 5 & Totals \\
\hline Previous hectares & 9 & 26 & 21 & 71 & 60 & 187 \\
\hline Mapped hectares & 18 & 26 & 32 & 69 & 101 & 246 \\
\hline Maximum peat thickness & $180 \mathrm{~cm}$ & $170 \mathrm{~cm}$ & $180 \mathrm{~cm}$ & $220 \mathrm{~cm}$ & $300 \mathrm{~cm}$ & \\
\hline Average peat thickness & $120 \mathrm{~cm}$ & $109 \mathrm{~cm}$ & $125 \mathrm{~cm}$ & $139 \mathrm{~cm}$ & $183 \mathrm{~cm}$ & \\
\hline Terric Haplosaprists (1) & 8 & 7 & 7 & 6 & 2 & 30 \\
\hline Terric Haplohemists (2) & 7 & 0 & 2 & 0 & 2 & 11 \\
\hline Typic Haplosaprists (3) & 1 & 1 & 0 & 0 & 1 & 3 \\
\hline Typic Haplohemists (4) & 2 & 1 & 4 & 4 & 0 & 11 \\
\hline Hemic Haplosaprists (5) & 7 & 0 & 1 & 0 & 2 & 10 \\
\hline Sapric Haplohemists (6) & 0 & 0 & 5 & 9 & 6 & 20 \\
\hline Fibric Haplohemists (7) & 0 & 0 & 0 & 0 & 1 & 1 \\
\hline Hemic Haplofibrists (8) & 0 & 0 & 0 & 0 & 2 & 2 \\
\hline Totals & 25 & 9 & 19 & 19 & 16 & 88 \\
\hline
\end{tabular}

Table 4- 1. Mapping results of the five peatlands. Parenthetic numbers following taxonomic classifications coordinate with the number scheme of Figure 4-3. 


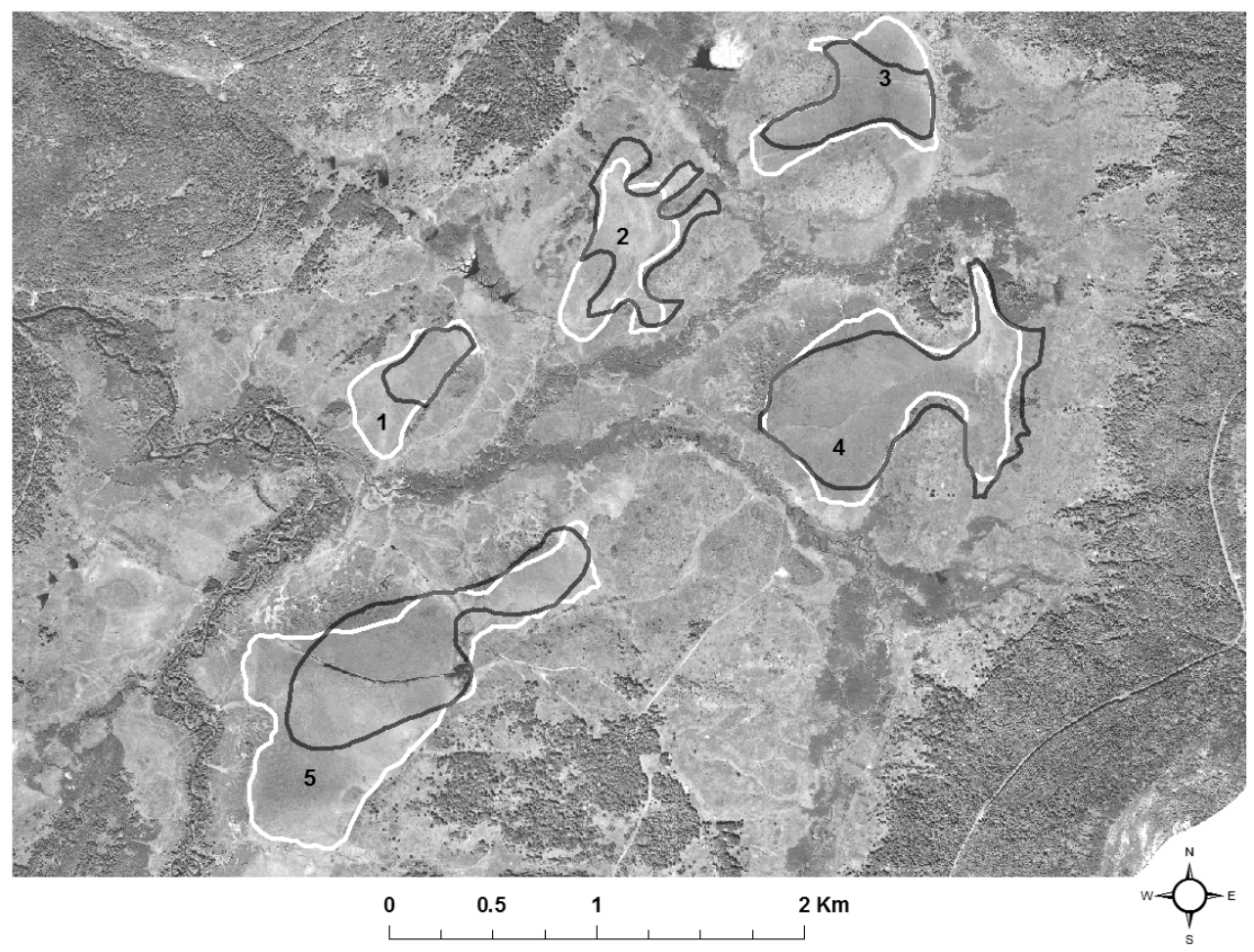

Figure 4- 2. Peatlands $1-5$ with previously mapped muck and peat (MP) soil map unit polygons outlined in black, and remapped Canaan Valley (CavA) soil map unit polygons in white. Aerial imagery obtained from the 2007 United States Department of Agriculture National Agriculture Inventory Program.

Peatland 1 (Figure 4-3a) was bound to the northwest by footslope wetlands, to the southwest by riparian areas, to the southeast by a tree-covered, bedrock high, and to the northeast by historic logging skids. Of 25 Histosol profiles in Peatland 1, eight were classified at the subgroup level as Terric Haplosaprists, seven as Terric Haplohemists, and seven as Hemic Haplosaprists. Hemic Haplosaprists were the most numerous soil profiles in the center of Peatland 1 where peat thickness was greatest.

Peatland 2 (Figure 4-3b) was irregular in shape, bound to the south by a riparian area and in other directions by uplands with very shallow bedrock. Seven of nine Histosol soil profiles in 
Peatland 2 were classified at the subgroup level as Terric Haplosaprists. One Typic Haplohemist and one Typic Haplosaprist were located in the center of Peatland 2 where peat thickness was greatest.

Peatland 3 (Figure 4-3c) was bound to the east by footslope wetlands, to the west and south by upland areas of shallow bedrock, and to the east by a riparian area. Seven of 19 Histosol soil profiles in of Peatland 3 were classified at the subgroup level as Terric Haplosaprists, with four Typic Haplohemists and five Sapric Haplohemists located in the center of Peatland 3 where peat thickness was the greatest.

Peatland 4 (Figure 4-3d) was bordered to the northwest and southwest by riparian areas, to the east by footslope, with two areas of uplands (Schaney and Schaney, in preparation). Peatland 4 had a few small areas of open water and some small areas of exposed mineral soil. Six of 19 Histosol soil profiles in of Peatland 4 were classified at the subgroup level as Terric Haplosaprists, with four Typic Haplohemists and nine Sapric Haplohemists located in the center of Peatland 4 where peat thickness was the greatest.

Peatland 5 (Figure 4-3e) was bordered to the north, west, and south by riparian areas and to the east by Middle Ridge. Extensive areas of standing water from numerous beaver dams occur south of the rail bed (Snyder et al., 2006). Of 16 Histosol soil profiles in Peatland 5, six were located where peat thickness is the greatest were classified at the subgroup level as Sapric Haplohemists. Peatland 5 also had a small area, just south of the beaver ponds, where one soil profile was classified as Fibric Haplohemist and two as Hemic Haplofibrists. 


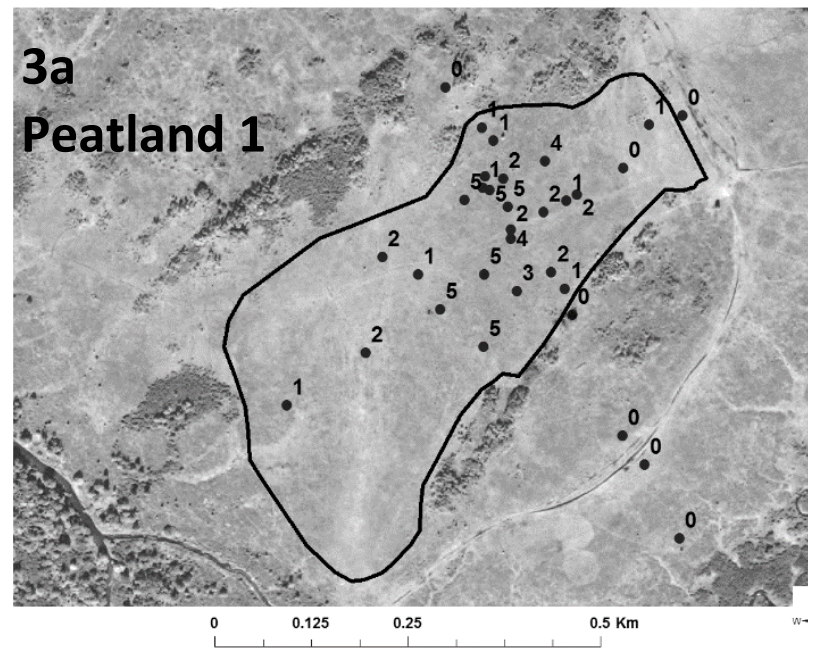

Figure 4- 3. The five mapped CVNWR peatlands with soil profiles labeled by classification.

Terric Haplosaprists are labeled as 1,

Terric Haplohemists as 2,

Typic Haplosaprists as 3,

Typic Haplohemists as 4,

Hemic Haplosaprists as 5,

Sapric Haplohemists as 6,

Fibric Haplohemist as 7, and

Hemic Haplofibrists as 8.
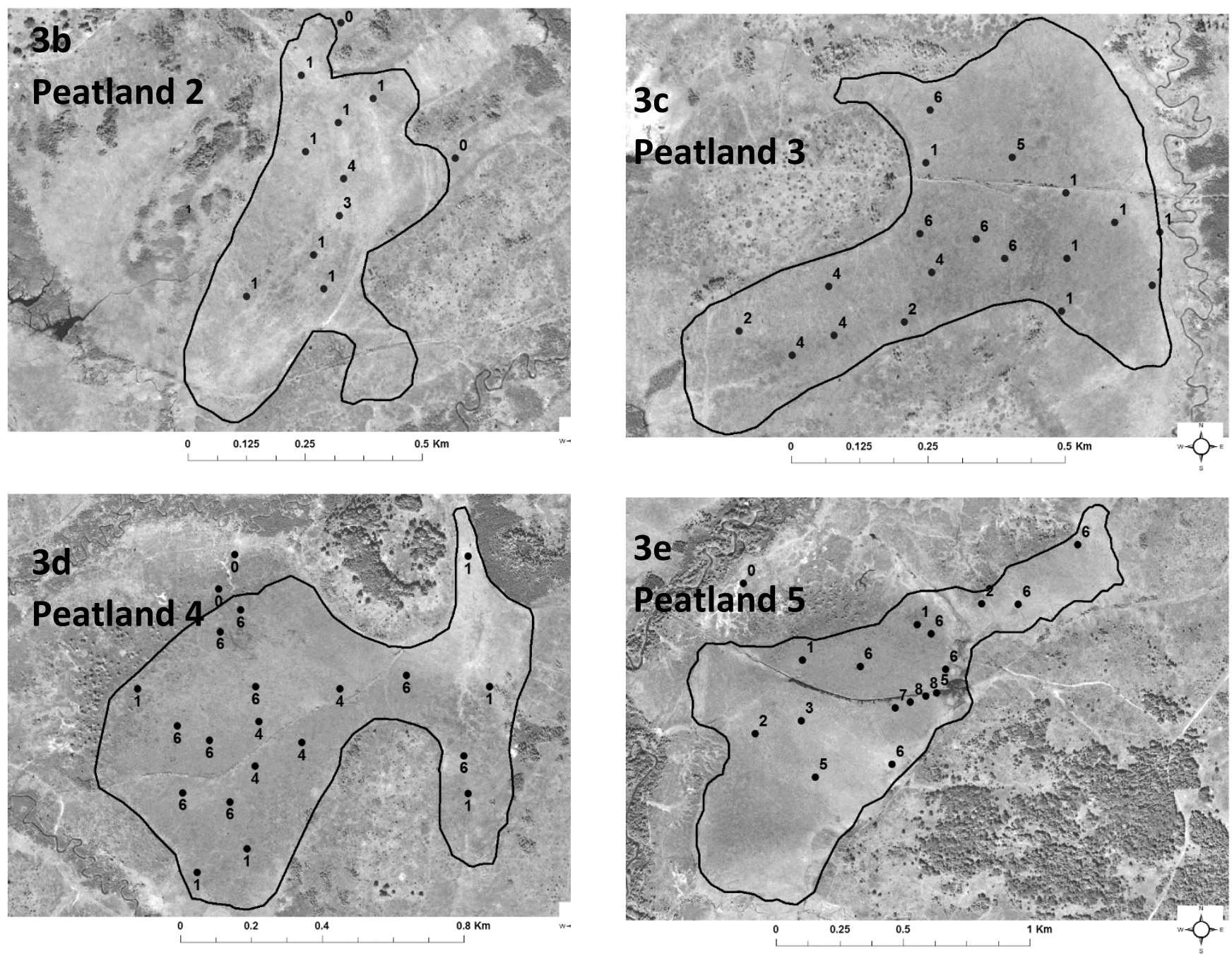
The five peatland landforms comprising the study areas had the thickest peat deposits in the interior of each landform and shallow peat along the edges. Generally, most soil profiles in CVNWR peatlands had similar horizonation trends. The acrotelm typically consisted of approximately $20 \mathrm{~cm}$ of fibric soil material, underlain by less than $10 \mathrm{~cm}$ of sapric soil material located at the water table. The catotelm in these profiles consisted of various thicknesses of a combination of hemic and sapric soil materials.

In the thickest deposits of Peatlands 2, 3, 4, and 5, the most common catotelm horizon sequence was hemic-sapric-hemic, which was also the most common horizon sequence in all CVNWR Histosols (Chapter 3), regardless of taxonomic control section. Soil Taxonomy has established an arbitrary control section for Histosols that extends to a depth of $130 \mathrm{~cm}$, soil classification does not extend past this depth (Soil Survey Staff, 1999). Horizon sequence does not always match taxonomic classification because 48 of the 88 Histosol profiles for this study extend deeper than the control section. Sequential radiocarbon dates from six cores, (Cores 1.86, $2.09,3.13,4.19,5.12$, and 5.17) yielded late Holocene dates correlating to the upper hemic horizon, mid-Holocene dates correlating to the sapric horizon, and late Pleistocene basal peat dates correlating to the lower hemic horizon (Chapters 2 and 3).

Sapric Haplohemists were the second-most numerous (19) CVNWR Histosol soil classification and contained the highest number of profiles with the hemic-sapric-hemic horizon sequence. All Sapric Haplohemists were located in the interior of the landforms where peat thickness is greatest, and best represent the horizons that characterize these natural bodies of soil, making them the best candidate as an official NRCS soil series. Terric Haplosaprists were the most numerous (30) soil profile classification, but only occur on the periphery of peatland landforms (Table 4-1 and Figure 4-3). Terric Haplosaprist profiles were shallow because of their 
landscape position and represent an ecotone transition from peatlands to the surrounding wetlands, and were considered inappropriate for designation as a new soil series. A modest number of soil profiles classified as Typic Haplohemists (11), Terric Haplohemists (11), Hemic Haplosaprists (10), or Typic Haplosaprists (3) (Table 4-1) vary in location and are too few to be represented as soil series. Hemic Haplofibrists (2) and Fibric Haplohemists (1) were the least numerous soil profiles characterized; all these profiles contained the hemic-sapric-hemic horizon sequence present in more common CVNWR Histosols, with the addition of a fibric horizon in the upper catotelm.

To ensure the characteristic natural bodies of soil in these five peatlands were not equivalent to existing soil series, the Sapric Haplohemist classification was compared to geographically associated Atkins, Blago, Brinkerton, and Lickdale soils series, located adjacent to the five study areas as identified by Losche and Beverage (1967). These series were all mineral soils and did not correlate to the Sapric Haplohemist classification.

Our Sapric Haplohemist classification was also compared to pre-existing Histosol soil series mapped within MLRA 127: Carlisle muck (Euic, mesic, Typic Haplosaprist) and Palms muck (Loamy, mixed, euic, mesic Terric Haplosaprist). CVNWR soil profiles from this investigation were best represented as Haplohemists, not Haplosaprists, and have a pH less than 4.5 in all parts of the organic material in the control section, making them dysic rather than euic. Furthermore, due to Canaan Valley's climate, the soil temperature was frigid rather than mesic (Sencindiver et al., 2015); hence, CVNWR soil profiles did not correlate to the two pre-existing MLRA 127 Histosols, which remain unrecognized in West Virginia.

Lastly, comparing our results to the only pre-existing Sapric Haplohemist soil series recognized by the NRCS, revealed that Mosesprairie peat in western Washington formed in 
organic materials over glaciolacustrine sediments and occurs in an isomesic temperature regime. In contrast, CVNWR soil profiles had a frigid soil temperature regime and were not formed over glaciolacustrine sediments, so Mosesprairie peat, was not correlative.

Working with NRCS soil scientists in state and local offices and in MLRA Soil Survey Region 6 Office, it was determined the Histosols investigated in CVNWR were outside the limits of any previously recognized NRCS soil series and had a unique set of properties. Hence, a new soil series was warranted. The family level characterization of the taxonomic classification of these soils was Dysic, frigid, Sapric Haplohemists. Canaan Valley series was assigned as the name of the new soil series (Schaney et al., 2018). Subsequently, the five peatlands within CVNWR were designated by a new soil survey map unit: Canaan Valley peat, moist, 0 to 3 percent slopes, represented by the map unit symbol CavA.

\section{Discussion}

Soils are a dynamic ecosystem constituent that act as the interface between the lithosphere, biosphere, atmosphere, and hydrosphere; they provide the foundation and structure of ecosystems. Meaningful ecosystem research regularly requires site-specific information on the processes affected by soils, and soil taxonomy is a critical component of such studies (Holden, 2005; Schimel and Chadwick, 2013). Goals of this research include characterizing, applying soil taxonomy principles to, and classifying these previously undescribed natural bodies of soil highlighting the value of classification of these rare and unique Histosols within CVNWR.

The Soil Survey Manual (Soil Science Division Staff, 2017) lists four main purposes of Soil Taxonomy (i) to facilitate communication among soil scientists, (ii) to provide names for 
taxa that are based on formative elements, (iii) to provide a link between the conceptual classes in Soil Taxonomy and actual natural bodies of soils, and (iv) to provide a way to transfer information and technology. Continuing research in the taxonomy and classification of soils is a priority within the broad movements of modern soil science, including classification of mine and quarry soils (Sencindiver and Ammons, 2000; Strain and Evans, 1994), urban soils (Capra et al., 2013; Effland and Pouyat, 1997), and subaqueous soils (Bakken and Stolt, 2018; Demas et al., 1996; Millar et al., 2015; Wessel et al., 2018; Wessel and Rabenhorst, 2017). These newly understood soils play a critical role in natural and anthropogenic ecosystems. Advancing such research contributes to the understanding of anthropogenic landscapes, land use change, newly recognized and rare ecosystems, and the global carbon cycle. Unique ecosystems such as CVNWR provide excellent locations and topics for taxonomic research. Coordinating such research with the NRCS not only provides extensive reliable experience, but also ensures research outcomes will be incorporated into national soils databases available for public use, such as the Web Soil Survey (Soil Survey Staff).

Soil series serve as a bridge between observed soils and conceptual taxonomic classes; they are important tools for naming, preserving, and communicating information about soils. Soil series also serve as tools for transferring knowledge about soil genesis, properties, and interpretations from place to place, wherever a given soil series is correlated to a map unit component (Soil Science Division Staff, 2017).

Although relatively homogenous soil map units are desirable, they are rarely attainable due to natural variations in individual soil properties and, in peatland landscapes, internal hydrology (Campbell and Edmonds, 1984). In most map units, areas of soil occur that do not meet all of the taxonomic criteria of the soil used to name the map unit and they normally 
consists of one or more components (Soil Science Division Staff, 2017). The new map unit CavA designates the new Canaan Valley series (Dysic frigid Sapric Haplohemists) and also contains components. Updated map units aid researchers and land use managers working in the Central Appalachians to understand the genesis and extent of these Histosols.

\section{Conclusions}

Histosols are important in both location and management, and they favor many special functions (Aandahl et al., 1974), including protected natural areas like CVNWR. The limited extent of Histosols in the Central Appalachians is a key aspect that makes them so important regionally. Histosols not only support unique ecosystems of high biodiversity and regionally rare plants (Bartgis et al., 2015; Byers et al., 2007; Fortney and Rentch, 2003; Fortney et al., 2015), but they also hold valuable paleoclimatic and paleoenvironmental proxies that record a pedomemory of these landscapes within their distinctive horizonation (Chapter 3). The interpretation of this pedomemory contributes to the regional paleoclimatic and paleoenvironmental body of knowledge. Current and future regional paleoclimate and paleoenvironmental studies conducted in similar Allegheny Mountain peatlands greatly benefit from taxonomic classification of soil to assist in interpreting the genesis and development of the individual ecosystems.

Peatland ecosystems and their carbon-rich organic soils have been studied for several decades, mainly as archives of paleoclimate and paleoenvironmental proxies, but more recently for their importance in the global carbon budget (Yu et al., 2009). Understanding the depth, extent, and differing decomposition of organic-rich horizons in Histosols can lead to more accurate accounts of peatland carbon storage (Millar et al., 2015; Zauft et al., 2010; Malmer et al., 2011). The representative horizonation as documented in official series descriptions and the 
variability in this horizonation within the peatland soil map units will yield even more accurate inventories of terrestrial carbon stocks. Distribution of the Canaan Valley series includes other high elevation peatlands in MLRA 127 (Schaney et al., 2018). Small-scale ecosystems are underestimated in the global carbon budget (Millar et al., 2015); future carbon research in the relatively small Appalachian peatlands will contribute to the greater knowledge of carbon storage. Specifically, the USDA Forest Service Forest Inventory and Analysis Program includes soil carbon calculations by state for public and private forested areas (Chimner et al., 2104; USDA Forest Service, 2015).

Formal recognition of the Canaan Valley series and its associated taxonomic classification convey a level of significance that was not apparent when these Histosols were mapped as unnamed and unclassified muck and peat. The Canaan Valley official series description and Dysic, frigid Sapric Haplohemists classification impart key information about, the makeup of the soils, how they formed, and insight into how they should be managed. Ecologists, soil scientists, paleoenvironmental scientists, and U.S Fish and Wildlife Service landuse managers may all benefit from this research contributions to a more complete understanding of CVNWR Histosols and the ecosystems they support. 


\section{References}

Aandahl, A., S.W. Buol, D.E. Hill, and H.H. Bailey. 1974. Histosols: their characteristics, classification, and use. Soil Science Society of America, Madison, Wisconsin.

Allard, H.A., and E.C. Leonard. 1952. The Canaan and the Stony River valleys of West Virginia, their former magnificent spruce forests, their vegetation and floristics today. Castanea 17(1):1-60.

Bakken, J., and M.H. Stolt. 2018. Mapping freshwater subaqueous soil resources: Examples from Southern New England. Soil Science Society of America Journal 82(2):403-412.

Bartgis, R.L., E.A. Byers, R.H. Fortney, W. Grafton, and M.A. Berdine. 2015. Rare plants of Canaan Valley, West Virginia. Southeastern Naturalist 14(7):158-186.

Beilman, D.W., G.M. MacDonald, and Z. Yu. 2010. The northern peatland carbon pool and the Holocene carbon cycle. PAGES 18(1):22-25.

Bonner, J.L., J.T. Anderson, J.S. Rentch, and W.N. Grafton. 2009. Vegetative composition and community structure associated with beaver ponds in Canaan Valley, West Virginia, USA. Wetlands Ecology and Management 17(5):543-554.

Bronk Ramsey, C. 2009. Bayesian analysis of radiocarbon dates. Radiocarbon, 51(1):337-360.

Buol, S.W., F.D. Hole, R.J. McCracken, and R.J. Southard. 1997. Soil Genesis and Classification, 4th ed. Iowa State University Press, Ames.

Byers, B.E., J.P. Vanderhorst, B.P. Streets, and B.T.L. Wolf. 2007. Classification and Conservation Assessment of High Elevation Wetland Communities in the Allegheny Mountains of West Virginia. West Virginia Division of Natural Resources Technical Report.

Cameron, C.C. 1970. Peat Resources of the unglaciated uplands along the Allegheny structural front in West Virginia, Maryland, and Pennsylvania. Geologic Survey Research 1970, Chapter D: U.S. Geologic Survey Professional Paper 700-D:153-161.

Cameron, C.C., J.S. Esterle, and C.A. Palmer. 1989. The geology, botany and chemistry of selected peat-forming environments from temperate and tropical latitudes. International Journal of Coal Geology 12(1-4):105-156.

Campbell, J.B., and W.J. Edmonds. 1984. The missing geographic dimension to soil taxonomy. Annals of the Association of American Geographers 74(1):83-97.

Capra, G.F., S. Vacca, E. Cabula, E. Grilli, and A. Buondonno. 2013. Through the decades: Taxonomic proposals for human-altered and human-transported soil classification. Soil Horizons 54(2). https://doi.org/10.2136/sh12-12-0033

Carlisle, S.C., H.R. Mount, and J.H. Brown. 1998. The Mechanics of Soil Survey. National Soil Survey Center, Lincoln, Nebraska.

Chadbourne, K.A., and J.T. Anderson. 2015. Vegetation of managed grasslands in the Canaan 
Valley National Wildlife Refuge. Southeastern Naturalist 14 (7):187-202.

Chimner, R.A., C.A. Ott, C.H. Perry, and R.K. Kolka. 2014. Developing and Evaluating Rapid Field Methods to Estimate Peat Carbon. Wetlands 34(6):1241-1246.

Core, E.L. 1950. Notes on the plant geography of West Virginia. Castanea 15(2):61-79.

Daniels, R.B., and R.D. Hammer. 1992. Soil Geomorphology, Earth Surface Processes and Landforms. Wiley-Blackwell, New York.

Demas, G.P., M.C. Rabenhorst, and J.C. Stevenson. 1996. A pedological approach to the study of shallow-water habitats. Estuaries 19(2):229-237.

Diehl, J.W., and R.E. Behling. 1982. Geologic factors affecting formation and presence of wetlands in the north central section of the Appalachian Plateaus Province of West Virginia. In: Symposium on Wetlands of the Unglaciated Appalachian Region. Morgantown, West Virginia, p. 20-26.

Dirt Wheels Magazine. 2018. The Famouse Blackwater 100, Great Moments in ATV History. https://dirtwheelsmag.com/the-famous-blackwater-100/

Dommain, R., J. Couwenberg, P.H. Glaser, H. Joosten, and I.N.N. Suryadiputra. 2014. Carbon storage and release in Indonesian peatlands since the last deglaciation. Quaternary Science Reviews 97:1-32.

Effland, W.R., and R.V. Pouyat. 1997. The genesis, classification , and mapping of soils in urban areas. Urban Ecosystems 1(4):217-228.

Faust, A., and R.L. Petersen. 2015. Longevity of interrupted fern colonies. Southeastern Naturalist 14(7):203-209.

Fenneman, N.M., and D.W. Johnson. 1946. Physiographic Divisions of the United States. U.S. Geological Survey, Washington D.C.

Fortney, R.H., and J.S. Rentch. 2003. Post logging era plant successional trends and geospatial vegetation patterns in Canaan Valley, West Virginia, 1945 to 2000. Castanea 68(4): 317334.

Fortney, R.H., S.L. Stephenson, and J.S. Rentch. 2015. Rare plant communities in Canaan Valley, West Virginia. Southeastern Naturalist 14(7):121-135.

Francl, K.E., W.M. Ford, and S.B. Castleberry. 2004. Characterization of High Elevation Central Appalachian Wetlands. Research Paper NE-725. Newton Square, PA.

Franzen, L.G., F. Lindberg, V. Viklander, and A. Walther. 2012. The potential peatland extent and carbon sink in Sweden, as related to the Peatland/Ice Age Hypothesis. Mires and Peat 10:1-19.

Givelet, N., G. Le Roux, A. Cheburkin, B. Chen, J. Frank, M.E. Goodsite, H. Kempter, M. Krachler, T. Nørnberg, N. Rausch, S. Rheinberger, F. Roos-Barraclough, A. Sapkota, C. Scholz, and W. Shotyk. 2004. Suggested protocol for collecting, handling and preparing 
peat cores and peat samples for physical, chemical, mineralogical and isotopic analyses. Journal of Environmental Monitoring 6(4):1464-0325.

Grafton, W.N., and R.H. Fortney. 2015. Exotic and invasive plants in Canaan Valley. Southeastern Naturalist 14(7):210-217.

Holden, J. 2005. Peatland hydrology and carbon release: why small-scale process matters. Philosophical Transactions of the Royal Society A, Mathematical, Physical and Engineering Sciences 363(1837):2891-2913.

Ingham, M.E. 1996. The bog region of the Allegheny Mountians of West Virginia. University of South Florida, Tampa, Florida, Master's Thesis.

Ireland, A.W., R.K. Booth, S.C. Hotchkiss, and J.E. Schmitz. 2013. A comparative study of within-basin and regional peatland development: Implications for peatland carbon dynamics. Quaternary Science Reviews 61:85-95.

Kolka, R., S.D. Bridgham, and C.L. Ping. 2016. Soils of peatlands: histosols and gelisols. In: M.J. Vepraskas, M.J.; Craft, C.L. (eds.), Wetlands Soils: Genesis, Hydrology, Landscapes and Classification. CRC Press/Lewis Publishing, Boca Raton, p. 277-309.

Kost, M.A., D.A. Albert, J.G. Cohen, B.S. Slaughter, R.K. Schillo, C.R. Weber, and K.A. Chapman. 2007. Natural Communities of Michigan: Classification and Description. Michigan Natural Features Inventory, Report Number 2007-21, Lansing, MI.

Langdon, P.G., A.G. Brown, C.J. Caseldine, S.P.E. Blockley, and I. Stuijts. 2012. Regional climate change from peat stratigraphy for the mid- to late Holocene in central Ireland. Quaternary International 268:145-155.

Loisel, J., and M. Garneau. 2010. Late Holocene paleoecohydrology and carbon accumulation estimates from two boreal peat bogs in eastern Canada: Potential and limits of multi-proxy archives. Palaeogeography, Palaeoclimatology, Palaeoecology 291(3):493-533.

Losche, C.K., and W.W. Beverage. 1967. Soil Survey of Tucker County and Part of Northern Randolph County, West Virginia. Soil Conservation Service, Washington DC.

Malmer, N., G. Svensson, and B. Wallén. 2011. Carbon and mass balance in a south Swedish ombrotrophic bog: processes nd variation during recent centuries. Mires and Peat 8(1):116.

Matchen, D.L. 2015. The geology of Canaan Valley. Southeastern Naturalist 14(7):7-17.

McDonald, B. 2015. Rare plant and animal species of Canaan Valley. Southeastern Naturalist 14(7):232-251.

Millar, C.M., A.A. Owusu Aduomih, B. Still, and M.H. Stolt. 2015. Estuarine subaqueous soil organic carbon accounting: sequestration and storage. Soil Science Society of America Journal 79(2):389-397.

Nauman, T.W., J.A. Thompson, S.J. Teets, T.A. Dilliplane, J.W. Bell, S.J. Connolly, H.J. Liebermann, and K.M. Yoast. 2015. Ghosts of the forest: Mapping pedomemory to guide forest restoration. Geoderma 247-248:51-64. 
Page, S.E., J.O. Rieley, and C.J. Banks. 2011. Global and regional importance of the tropical peatland carbon pool. Global Change Biology 17(2):798-818.

Piotrowska, N., M. Blaauw, D. Mauquoy, and F.M. Chambers. 2010. Constructing deposition chronologies for peat deposits using radiocarbon dating. Mires and Peat, 7, article 10, 1-14.

Reger, J., and E. Cleaves. 2008. Physiographic map of Maryland. Maryland Geological Survey, Baltimore, Maryland.

Reimer, P. J., E. Bard, A. Bayliss, J. W. Beck, P. G. Blackwell, C. Bronk Ramsey, P.M. Grootes, T. P. Guilderson, H. Haflidason, I. Hajdas, C. HattŽ, T. J. Heaton, D. L Hoffmann, A. G Hogg, K. A. Hughen, K. F. Kaiser, B. Kromer, S. W. Manning, M. Niu, R. W. Reimer, D. A. Richards, E. M. Scott, J. R. Southon, R. A. Staff, C. S. M. Turney, and J. van der Plicht. 2013. IntCal13 and Marine13 radiocarbon age calibration curves 0-50,000 years cal BP. Radiocarbon, 55(4):1869-1887.

Rentch, J.S., and J.T. Anderson. 2000. Stand development of trembling aspen in Canaan Valley, West Virginia. In, Proceedings of the 16th Central Hardwoods Forest Conference 413-422.

Rentch, J.S., J.T. Anderson, S. Lamont, J. Sencindiver, and R. Eli. 2008. Vegetation along hydrologic, edaphic, and geochemical gradients in a high-elevation poor fen in Canaan Valley, West Virginia. Wetlands Ecology and Management 16(3):237-253.

Rigg, G.B., and P.D. Strausbaugh. 1949. Some stages in the development of sphagnum bogs in West Virginia. Castanea 14(4):129-148.

Rumpel, C., and I. Kögel-Knabner. 2011. Deep soil organic matter-a key but poorly understood component of terrestrial C cycle. Plant and Soil 338(1-2): 143-158.

Rumpel, Cornelia. 2014. Opportunities and threats of deep soil organic matter storage. Carbon Management. 5(2):115-117.

Schaney, C.R., and M.L. Schaney. in preparation. Assessing the impact of anthropogenic activities in peatlands of Canaan Valley National Wildlife Refuge.

Schaney, M., C.R. Schaney, and J.W. Bell. 2018. Canaan Valley Series. Natural Resource Conservation Service, Official Series Description, https://soilseries.sc.egov.usda.gov/OSD_Docs/C/CANAAN_VALLEY.html.

Schimel, J., and O. Chadwick. 2013. What's in a name? The importance of soil taxonomy for ecology and biogeochemistry. Ecology and the Environment 11(8):405-406.

Sencindiver, J., K. Thomas, and J. Teets. 2015. Soils of Canaan Valley and adjacent mountains. Southeastern Naturalist 14 (7):33-39.

Sencindiver, J.C., and J.T. Ammons. 2000. Minesoil genesis and classification. Reclamation of Drastically Disturbed Lands 1948:595-614.

Sevon, W. 2018. Physiographic provinces of Pennsylvania. Commonwealth of Pennsylvania Department of Conservation and Natural Resources, Bureau of Topographic and Geologic Survey, Harrisburg, Pennsylvania. 
Snyder, C.D., J.A. Young, and B.M. Stout III. 2006. Aquatic habitats of Canaan Valley, West Virginia: Diversity and environmental threats. Northeastern Naturalist 13(3):333-352.

Soil Science Division Staff. 2017. Soil Survey Manual, C. Ditzler, K. Scheffe, and H.C. Monger (eds.). USDA Handbook 18. Government Printing Office, Washington, D.C.

Soil Survey Staff, Natural Resources Conservation Service, United States Department of Agriculture. Web Soil Survey. Available online at the following link: https://websoilsurvey.sc.egov.usda.gov/. Accessed [10/10/2018].

Soil Survey Staff. 2014. Kellog Soil Survey Laboratory Methods Manual; Soil Survey Investigations Report No. 42, Version 5. U.S. Department of Agriculture, Natural Resources Conservation Service.

Soil Survey Staff. 1999. Soil Taxonomy A Basic System of Soil Classification for Making and Interpreting Soil Surveys United States Department of Agriculture Natural Resources Conservation Service.

Stewart, C.N., and E.T. Nilsen. 1993. Association of edaphic factors and vegetation in several isolated Appalachian peat bogs. Bulletin of the Torrey Botanical Club 120(2):128-135.

Stine, M.B., L.M. Resler, and J.B. Campbell. 2011. Ecotone characteristics of a southern Appalachian Mountain wetland. Catena 86:57-65.

Strain, M.R., and C.V. Evans. 1994. Map unit development for sand-pit nd gravel-pit soils in New Hampshire. Soil Science Society of America Journal 58(1):147-155.

Tuittila, E., S. Juutinen, S. Frolking, M. Väliranta, A. M. Laine, A. Miettinen, M. Seväkivi, A. Quillet, A., and P. Merilä. 2012. Wetland chronosequence as a model of peatland development: Vegetation succession, peat and carbon accumulation. The Holocene, 23(1):25-35.

USDA Forest Service. 2015. Baseline Estimates of Carbon Stocks in Forests and Harvested Wood Products for National Forest System Units; Eastern Region. 58 pp. http://www.fs.fed.us/climatechange/documents/EasternRegionCarbonAssessmentTwoBasel ines. pdf

Vitt, D.H. 2006. Bryophyte community ecology: Going beyond description. Lindbergia 31:3341.

Vogel, C.A., and R.J. Leffler. 2015. Climate of Canaan Valley. Southeastern Naturalist 14(7):18-32.

Walbridge, M.R. 1994. Plant community composition and surface water chemistry of fen peatlands in West Virginia's Appalachian Plateau. Water, Air, and Soil Pollution 77(34):247-269.

Warren, M.W., J.B. Kauffman, D. Murdiyarso, G. Anshari, K. Hergoualc'H, S. Kurnianto, J. Purbopuspito, E. Gusmayanti, M. Afifudin, J. Rahajoe, L. Alhamd, S. Limin, and A. Iswandi. 2012. A cost-efficient method to assess carbon stocks in tropical peat soil. Biogeosciences 9(11):4477-4485. 
Wessel, B.M., J.M. Galbraith, M.H. Stolt, M.C. Rabenhorst, D.S. Fanning, and M.J. Levin. 2018. Soil taxonomy proposals for acid sulfate soils and subaqueous soils raised by the 8th International Acid Sulfate Soils Conference. South African Journal of Plant and Soil 35(4):293-295. https://doi.org/10.1080/02571862.2017.1387820

Wessel, B.M., and M.C. Rabenhorst. 2017. Identification of sulfidic materials in the Rhode River subestuary of Chesapeake Bay. Geoderma 308:215-225.

West Virginia Geologic and Economic Survey, 2017. Physiographic provinces of West Virginia. West Virginia Geologic and Economic Survey, Morgantown, West Virginia.

Western Regional Climate Center. 2016. Canaan Valley, West Virginia (461393), Period of Record Monthly Climate Summary. [WWW Document]. URL http://www.wrcc.dri.edu/cgibin/cliMAIN.pl?wv1393

Whitehead, D.R. 1965. Palynology and Pleistocene phytogeography of unglaciated eastern United States. In: Wright, H.E.J., Frey, D.G. (eds.), The Quaternary of the United States. Princeton University Press, Princeton, NJ, p. 417-432.

Yu, Z., D.W. Beilman, S. Frolking, G.M. MacDonald, N.T. Roulet, P. Camill, and D.J. Charman. 2011. Peatlands and their role in the global carbon cycle. Eos, Transactions American Geophysical Union 92(12):97-98.

Yu, Z., D.W. Beilman, and M.C. Jones. 2009. Sensitivity of northern peatland carbon dynamics to Holocene climate change, in Carbon Cycling in Northern Peatlands, Geophysical Monograph Series 184, p. 55-69.

Yu, Z., J. Loisel, D.P. Brosseau, D.W. Beilman, and S.J. Hunt. 2010. Global peatland dynamics since the Last Glacial Maximum. Geophysical Research Letters 37(13). https://doi.org/10.1029/2010GL043584

Zauft, M., H. Fell, F. Glaßer, N. Rosskopf, and J. Zeitz. 2010. Carbon storage in the peatlands of Mecklenburg-Western Pomerania, north-east Germany. Mires and Peat 6(4):1-12. 


\section{Chapter 5}

\section{Summary}

The preceding dissertation research can be characterized as an investigation of the organic soils of five CVNWR peatlands. Obtaining radiocarbon dates was a primary goal and procuring funding for dating was initiated early in this process. The Radiocarbon Collaborative and USFWS funding enabled more dates than anticipated to be obtained, and allowed a more comprehensive high-resolution chronology than would have otherwise been possible. As discussed in Chapter 2, the radiocarbon chronology turned out to be more complex and older than suggested by other regional studies. Comparing and interpreting previous research of Allegheny Mountains peatlands proved to be difficult due to inconsistency in sediment profile descriptions. It is suggested that future peatland research, whatever the intent may be, include full soil profile descriptions using standardized NRCS soil science terminology.

Coring and describing the soils was a second goal for this research, which led to the unexpected results of observing a distinct pattern within the sequence of soil horizons as discussed in Chapter 3. Pedomemory recorded in the soil profiles revealed a paleoclimate proxy that was substantiated by the large number of soil cores profiled. Peat stratigraphy is a useful tool in paleoclimate research, but has not been utilized previously in the Allegheny Mountains and very little in the eastern United States. Proper peat stratigraphy descriptions and interpretations require a working knowledge of soil science. Again, reinforcing full soil profile descriptions using standardized USDA soil science terminology should be standard for peatland research.

The third goal of this research was to classify these organic soils according to Soil Taxonomy and submit that classification to the NRCS for formal series adoption, as discussed in 
Chapter 4. The process of designating a new soil series and incorporating new soil map units into the federal database and websites advanced faster than anticipated and has already been finalized. It is anticipated that Chapters 2, 3, and 4 of this dissertation will be published in geomorphology, quaternary, or pedology journals. Cores collected for laboratory analysis are currently stored frozen in the basement of Krebs Hall of the University of Pittsburgh at Johnstown, the author's current location of employment.

As good research tends to do this study brought forth many new research questions regarding pedology, geomorphology, and paleoclimate of Canaan Valley National Wildlife Refuge (CVNWR) peatlands and Histosols. Pollen analysis, peat humification, loss on ignition, and macroscopic charcoal analysis of the two thickest peat cores is being conducted currently by Environmental Science undergraduate researchers at Berry College led by Dr. Zachary Taylor. Preliminary analysis of peat humification based upon high light transmissivity and low organic matter content with high macrocharcoal counts corroborates a dry mid-Holocene Climatic Optimum as discussed in Chapters 2 and 3. Mapping efforts will also continue within CVNWR by creating a three-dimensional digital map of the peat thickness within the five peatlands. Depth probe data was previously collected and will be processed as part of undergraduate student research at University of Pittsburgh at Johnstown Geography Department led by myself. Further research could also be conducted using ground penetrating radar to map the organic soil mineral soil interface. Pairing that information with mineral soil samples already collected will further the inquiry of landform development of the five CVNWR peatlands. Calculating carbon storage in CVNWR peatlands, as well as other Allegheny Mountain peatlands, to be incorporated into the soil carbon data collected by the USDA Forest Service Forest Inventory and Analysis Program, is also a future goal of this continuing research. Coupling a carbon balance exercise 
with projected future climate change scenarios would be beneficial for the land-use managers of the Allegheny Mountain peatlands.

I would also like to expand this research to the other Allegheny Mountain peatlands. The four peatlands in Cranberry Glades Botanical Area have thick peat deposits and a large surface area. Preliminary soil sampling revealed thick, intact organic soil deposits. Cranberry Glades will be prioritized for future research. Preliminary soil sampling and site reconnaissance has also been completed at Big Run Bog, Buckles Bog (The Glades), and Cranesville Swamp. It is of scientific value to explore these Histosols to determine if they are of similar age and if they show a similar pedomemory of late Pleistocene and Holocene climatic fluctuations. Several other locations, reported as peatlands, also were visited for soil sampling but did not contain Histosols. 


\section{Appendix A: Soil Profile Descriptions and Data}

The following written soil profile descriptions are organized by core number and include lab data where applicable. Each individual soil profile states the taxonomic classification, the date described in the field, and by whom. Some include location or surface vegetation descriptions where noted. Location is given in latitude and longitude decimal degrees with negative values indicating longitude west.

\section{Classification assumptions:}

- Mineral Soil if organic content (by LOI) is less than $20 \%$

- $\quad$ Histosol if:

- No andic soil properties

- Saturated 30 days or more (these peatlands are saturated year-round)

- $40 \mathrm{~cm}+$ of organic sapric or hemic soil material

- $\quad$ Control section down to $130 \mathrm{~cm}$

- Surface tier $0-30 \mathrm{~cm}$

- Subsurface tier $30-90 \mathrm{~cm}$

- Bottom tier 90-130cm

- $\quad$ Suborders

- Fibrist if majority fibric soil in subsurface tier

- Saprist if majority sapric soil in subsurface tier

- Hemist - other Histosols

- $\quad$ Great Groups

- No sulfur

- Not cryic

- $\quad$ Subgroups

- All are Haplo

- Lithic if bedrock contact in control section $(130 \mathrm{~cm})$

- Limnic if $5 \mathrm{~cm}$ or more limnic horizon in control section

- Not Halic

- Terric if mineral layer within control section $(130 \mathrm{~cm})$

- Not fluvial

- Hemic if $25 \mathrm{~cm}$ or more of hemic in control section, below surface tier

- Sapric if $25 \mathrm{~cm}$ or more of sapric in control section, below surface tier

- Fibric if $25 \mathrm{~cm}$ or more of fibric in control section, below surface tier

- Typic if other

- $\quad$ Fibric horizon designation if:

- contains $75 \%$ or more of fibers after rubbing or $40 \%$

- a pyrophosphate color of $7 / 1,7 / 2,8 / 1,8 / 2$, or $8 / 3$

- bulk density of less than $0.1 \mathrm{~g} / \mathrm{cm}^{3}$

- $\quad$ Sapric horizon designation if:

- Fiber content after rubbing is less than $17 \%$ AND

- Pyrophosphate color as designated on Diagram 2 in Soil Taxonomy (p. 88)

- Bulk density usually greater than $0.2 \mathrm{~g} / \mathrm{cm}^{3}$ 
- Hemic horizon designation if organic soil does not meet either Fibric or Sapric requirements

- Bulk density usually between 0.07 and $0.18 \mathrm{~g} / \mathrm{cm}^{3}$

- $\quad$ Lab data was preferred over field descriptions if different.

- $\quad$ For terric subgroup classification, it is assumed that mineral soil continues to depth even if $30 \mathrm{~cm}$ of mineral was not retrieved in core. 


\section{Individual Soil Profiles}

Canaan Valley National Wildlife Refuge, Davis, Tucker County, West Virginia 4 June 2014

Profile 1.01, Terric Haplosaprist

Location: $39.1337,-79.384$

Compiled by M. Schaney, J. Teets, and S. Marsh

Oi - - 0 to 12 centimeters; dark brown (10YR 3/3) unrubbed fibric peat; 100 per cent unrubbed fibers; 98 per cent rubbed fibers.

Oa1 - - 12 to 26 centimeters; black (10YR 2/1) unrubbed sapric muck with 20 per cent silty clay; 10 per cent unrubbed fibers; 7 per cent rubbed fibers.

Oa2 - 26 to 62 centimeters; black (10YR 2/1) unrubbed sapric muck; 25 per cent unrubbed fibers; 5 per cent rubbed fibers; coniferous needles.

Oa3 - - 62 to 80 centimeters; very dark gray (5YR 3/1) unrubbed sapric muck with 25 per cent silt, 30 per cent unrubbed fibers; 3 per cent rubbed fibers.

C- - 80 to 93 centimeters; dark brown (7.5YR 3/2) silty clay.

Cg1- - 93 to 98 centimeters; grayish brown (2.5Y 5/2) silty clay.

Cg2- - 98 to 99 centimeters; weak red (2.5YR 5/2) silty clay; 5 per cent decayed sandstone pebbles and 15 per cent siltstone fragments. 
Canaan Valley National Wildlife Refuge, Davis, Tucker County, West Virginia

4 June 2014

Profile 1.02, Terric Haplohemist

Location: $39.13310,-79.38370$

Compiled by M. Schaney, J. Teets, and S. Marsh

Oi1 - - 0 to 9 centimeters; dark brown (10YR 3/3) unrubbed fibric peat; 100 per cent unrubbed fibers; 98 per cent rubbed fibers.

Oi2 - - 9 to 19 centimeters; very dark brown (7.5YR 2.5/3) unrubbed fibric peat; 60 per cent unrubbed fibers; 50 per cent rubbed fibers. Water table at 20 centimeters.

Oa - - 19 to 38 centimeters; very dark brown (10YR 2/2) unrubbed sapric muck; 65 per cent unrubbed fibers; 3 per cent rubbed fibers; black round seeds.

Oe - - 38 to 95 centimeters; very dark brown (7.5YR 2.5/2) unrubbed hemic sedge mucky peat, 80 per cent unrubbed fibers; 25 per cent rubbed fibers.

Oa- - 95 to 123 centimeters; dark brown (7.5YR 3/2) unrubbed sapric muck; 80 per cent unrubbed fibers; 10 per cent rubbed fibers; lighter appearance.

Cg- - 123 to 132 centimeters; grayish brown (2.5Y 5/2) silt loam with visible sand and 15 per cent fibers. 
Canaan Valley National Wildlife Refuge, Davis, Tucker County, West Virginia

4 June 2014

Profile 1.03, Typic Haplohemist

Location: 39.1324, -79.3836, decrease in heather increase in sedges

Compiled by M. Schaney, J. Teets, and S. Marsh

Oi1 - - 0 to 9 centimeters; dark brown (10YR 3/3) unrubbed fibric peat; 100 per cent unrubbed fibers; 98 per cent rubbed fibers.

Oi2 - - 9 to 21 centimeters; very dark brown (7.5YR 2.5/3) unrubbed fibric peat; 60 per cent unrubbed fibers; 50 per cent rubbed fibers. Water table at 20 centimeters.

Oa - - 21 to 35 centimeters; black (10YR 2/1) unrubbed sapric muck; 35 per cent unrubbed fibers; 3 per cent rubbed fibers.

Oe1 - - 35 to 107 centimeters; very dark brown (7.5YR 2.5/2) unrubbed hemic sedge mucky peat, 70 per cent unrubbed fibers; 22 per cent rubbed fibers.

Oe2- - 107 to 148 centimeters; dark brown (7.5YR 3/2) unrubbed hemic mucky peat; 60 per cent unrubbed fibers; 22 per cent rubbed fibers; spongy consistence.

Cg- - 148 to 150 centimeters; grayish brown (2.5Y 5/2) silt loam. 
Canaan Valley National Wildlife Refuge, Davis, Tucker County, West Virginia

5 June 2014

Profile 1.04, Terric Haplohemist

Location: $39.13200,-79.38300$, decrease in heather increase in sedges

Compiled by M. Schaney and S. Marsh

Oi1 - - 0 to 9 centimeters; reddish brown (5YR 4/4) unrubbed fibric peat; 100 per cent unrubbed fibers; 98 per cent rubbed fibers.

Oi2 - - 9 to 18 centimeters; very dark brown (7.5YR 2.5/3) unrubbed fibric peat; 95 per cent unrubbed fibers; 90 per cent rubbed fibers.

Oa1 - - 18 to 34 centimeters; black (10YR 2/1) unrubbed sapric muck with clay; 30 per cent unrubbed fibers; 1 per cent rubbed fibers.

Oa2 - - 34 to 55 centimeters; black (5YR 2.5/1) unrubbed sapric muck, 60 per cent unrubbed fibers; 5 per cent rubbed fibers.

Oe- - 55 to 122 centimeters; dark brown (7.5YR 3/3) unrubbed hemic mucky peat; 85 per cent unrubbed fibers; 25 per cent rubbed fibers.

Cg- - 122 to 125 centimeters; grayish brown (2.5Y 5/2) fine sandy loam with 7 per cent fibers. 
Canaan Valley National Wildlife Refuge, Davis, Tucker County, West Virginia

5 June 2014

Profile 1.05, Terric Haplosaprist

Location: $39.13180,-79.38280$, more shrubs

Compiled by M. Schaney and S. Marsh

Oi1 - - 0 to 14 centimeters; dark brown (10YR 3/3) unrubbed fibric peat; 100 per cent unrubbed fibers; 98 per cent rubbed fibers.

Oi2 - - 14 to 27 centimeters; very dark brown (7.5YR 2.5/3) unrubbed fibric peat; 60 per cent unrubbed fibers; 50 per cent rubbed fibers.

Oa - - 27 to 62 centimeters; black (10YR 2/1) unrubbed sapric muck; 25 per cent unrubbed fibers; 3 per cent rubbed fibers; wood fragment at 50 centimeters.

Oe - - 62 to 126 centimeters; very dark brown (7.5YR 2.5/2) unrubbed hemic sedge mucky peat, 70 per cent unrubbed fibers; 22 per cent rubbed fibers; clear smooth boundary.

Cg- - 126 to 136 centimeters; grayish brown (2.5Y 5/2) silt loam with very fine sand. 
Canaan Valley National Wildlife Refuge, Davis, Tucker County, West Virginia

5 June 2014

Profile 1.06, Entisol

Location: $39.13150,-79.38270$, at treeline

Compiled by M. Schaney and S. Marsh

Oi - - 0 to 8 centimeters; yellow (2.5Y 7/6) unrubbed fibric peat; 90 per cent unrubbed fibers; 85 per cent rubbed fibers; smooth abrupt boundary.

A- - 8 to 14 centimeters; black (10YR 2/1) clay loam; small granular structure.

Cg1- - 14 to 24 centimeters; gray (2.5Y 5/1) clay, thin lens of dark gray (2.5Y 4/1) clay; few very fine roots; very weak angular blocky structure; smooth abrupt boundary.

Cg2- - 24 to 40 centimeters; dark yellowish brown (10YR 4/6) with 40 per cent brown (10YR $5 / 3$ ) clay; massive; common fine to medium roots.

R- - 40 centimeters; Greenbrier Limestone - collected sample. 
Canaan Valley National Wildlife Refuge, Davis, Tucker County, West Virginia

5 June 2014

Profile 1.07, Entisol

Location: 39.13380, -79.38100, next to logging skid/open water, bullrush, small sedges, wetter vegetation

Compiled by M. Schaney and S. Marsh

Oi - - 0 to 11 centimeters; yellow (2.5Y 7/6) unrubbed fibric peat; 90 per cent unrubbed fibers; 85 per cent rubbed fibers; clear smooth boundary.

Oa - - 11 to 28 centimeters; black (10YR 2/1) unrubbed sapric muck with clay; 20 per cent unrubbed fibers; 5 per cent rubbed fibers; clear smooth boundary; clay lens at 15 centimeters.

Cg1- - 28 to 65 centimeters; dark grayish brown (10YR 4/2) clay.

Cg2- - 65 to 92 centimeters; dark greenish gray (10Y 4/1) with 5 per cent yellowish brown (10YR 5/6) clay; more compact.

Cg3- - 92 to 118 centimeters; dark reddish gray (5YR 4/2) sandy clay loam.

R- - 118 centimeters; Greenbrier Limestone - collected sample. 
Canaan Valley National Wildlife Refuge, Davis, Tucker County, West Virginia

5 June 2014

Profile 1.08, Terric Haplosaprist

Location: 39.13370, -79.38150, more sedges and grasses, no shrubs, no forbs

Compiled by M. Schaney and S. Marsh

Oi1 - - 0 to 14 centimeters; reddish brown (5YR 4/4) unrubbed fibric peat; 100 per cent unrubbed fibers; 98 per cent rubbed fibers; clear smooth boundary.

Oi2 - - 14 to 34 centimeters; black (10YR 2/1) unrubbed fibric peat with some clay; 60 per cent unrubbed fibers; 50 per cent rubbed fibers; smooth gradual boundary; charcoal fragments at 28 centimeters.

Oa - - 34 to 46 centimeters; black (10YR 2/1) unrubbed sapric muck; 10 per cent unrubbed fibers; 2 per cent rubbed fibers; very abrupt smooth boundary.

Cg1- - 46 to 77 centimeters; dark grayish brown (10YR 4/2) clay.

Cg2- - 77 to 106 centimeters; dark greenish gray (10Y 4/1) with 5 per cent yellowish brown (10YR 5/6) clay; more compact.

Cg3- - 106 to 122 centimeters; dark reddish gray (5YR 4/2) sandy clay loam.

R- - 122 centimeters; fossiliferous limestone. 
Canaan Valley National Wildlife Refuge, Davis, Tucker County, West Virginia

5 June 2014

Profile 1.09, Entisol

Location: 39.13320, -79.38190, reeds and less sedges, lower water table, near motorcycle rut Compiled by M. Schaney and S. Marsh

Oi1 - - 0 to 9 centimeters; reddish brown (5YR 4/4) unrubbed fibric peat; 100 per cent unrubbed fibers; 98 per cent rubbed fibers; clear smooth boundary.

Oi2 - - 9 to 21 centimeters; black (10YR 2/1) unrubbed fibric peat with some clay; 60 per cent unrubbed fibers; 50 per cent rubbed fibers; smooth clear boundary.

Cg- - 21 to 51 centimeters; grayish brown (2.5Y 5/2) clay; gradual smooth boundary.

CR- - 51 to 121 centimeters; reddish brown (5YR 4/3) coarsening downward from clay to clay loam to sandy clay loam to decayed shale bedrock - possibly Mauch Chunk.

R- - 121 centimeters. 
Canaan Valley National Wildlife Refuge, Davis, Tucker County, West Virginia

5 June 2014

Profile 1.10, Terric Haplohemist

Location: $39.13290,-79.38260$

Compiled by M. Schaney and S. Marsh

Oi1 - - 0 to 12 centimeters; reddish brown (5YR 4/4) unrubbed fibric peat; 100 per cent unrubbed fibers; 98 per cent rubbed fibers; clear smooth boundary.

Oi2 - - 12 to 20 centimeters; black (10YR 2/1) unrubbed fibric peat; 85 per cent unrubbed fibers; 60 per cent rubbed fibers.

Oa - - 20 to 28 centimeters; black (10YR 2/1) unrubbed sapric muck; 15 per cent unrubbed fibers; 5 per cent rubbed fibers; clear smooth boundary.

Oe - - 28 to 83 centimeters; dark brown (7.5YR 3/3) unrubbed hemic mucky peat, 85 per cent unrubbed fibers; 25 per cent rubbed fibers, diffuse boundary.

Cg1- - 83 to 110 centimeters; olive gray (5Y 4/2) fine sandy loam with 50 per cent fibers.

Cg2- - 110 to 146 centimeters; grayish brown (2.5Y 5/2) clay.

Cg3- - 146 to 170 centimeters; dark reddish gray (5YR 4/2) clay with limestone pebbles. 
Canaan Valley National Wildlife Refuge, Davis, Tucker County, West Virginia

5 June 2014

Profile 1.11, Terric Haplohemist

Location: $39.13270,-79.38310$

Compiled by M. Schaney and S. Marsh

Oi1 - - 0 to 13 centimeters; reddish brown (5YR 4/4) unrubbed fibric peat; 100 per cent unrubbed fibers; 98 per cent rubbed fibers; clear smooth boundary.

Oi2 - - 13 to 22 centimeters; black (10YR 2/1) unrubbed fibric peat; 85 per cent unrubbed fibers; 60 per cent rubbed fibers.

Oa - - 22 to 69 centimeters; black (10YR 2/1) unrubbed sapric muck; 15 per cent unrubbed fibers; 5 per cent rubbed fibers; clear smooth boundary.

Oe1 - - 69 to 123 centimeters; reddish brown (5YR 4/3) unrubbed hemic mucky peat, 90 per cent unrubbed fibers; 30 per cent rubbed fibers, diffuse boundary.

Oe2 - - 123 to 150 centimeters; dark reddish brown (5YR 3/3) unrubbed hemic mucky peat, 90 per cent unrubbed fibers; 30 per cent rubbed fibers, diffuse boundary.

C- - 150 to 152 centimeters; fine sandy loam. 
Canaan Valley National Wildlife Refuge, Davis, Tucker County, West Virginia

6 June 2014

Profile 1.12, Terric Haplohemist, Full Core Sample

Location: $39.13250,-79.38360$

Compiled by M. Schaney, C. Schaney, and R. Fedders

Oi1 - - 0 to 10 centimeters; reddish brown (5YR 4/4) unrubbed fibric peat; 100 per cent unrubbed fibers; 98 per cent rubbed fibers; clear smooth boundary.

Oi2 - - 10 to 26 centimeters; black (10YR 2/1) unrubbed fibric peat; 85 per cent unrubbed fibers; 60 per cent rubbed fibers; clear smooth boundary.

Oa - - 26 to 58 centimeters; black (10YR 2/1) unrubbed sapric muck; 15 per cent unrubbed fibers; 5 per cent rubbed fibers; clear smooth boundary.

Oe - - 58 to 98 centimeters; dark reddish brown (5YR 3/3) unrubbed hemic mucky peat, 90 per cent unrubbed fibers; 35 per cent rubbed fibers, clear smooth boundary.

C- - 98 to 148 centimeters; very dark brown (7.5YR 2.5/2) fine sandy muck grading into a fine sandy loam; 68 per cent unrubbed fibers; 30 per cent rubbed fibers. 
Canaan Valley National Wildlife Refuge, Davis, Tucker County, West Virginia

6 June 2014

Profile 1.13 Terric Haplosaprist

Location: 39.13200, -79.38500, under pine tree, in motorcycle rut.

Compiled by M. Schaney, C. Schaney, and R. Fedders

Oi - - 0 to 4 centimeters; reddish brown (5YR 4/4) unrubbed fibric peat; 100 per cent unrubbed fibers; 98 per cent rubbed fibers; clear smooth boundary.

Oa1 - - 4 to 28 centimeters; black (10YR 2/1) unrubbed sapric muck; 15 per cent unrubbed fibers; 2 per cent rubbed fibers; common fine roots.

Oa2 - 28 to 62 centimeters; black (10YR 2/1) unrubbed sapric muck; 30 per cent unrubbed fibers; 10 per cent rubbed fibers; few fine roots.

Oe - - 62 to 80 centimeters; dark brown (7.5YR 3/4) unrubbed hemic mucky peat, 85 per cent unrubbed fibers; 35 per cent rubbed fibers, clear smooth boundary.

C1 - - 80 to 135 centimeters; very dark brown (7.5YR 2.5/2) fine sandy loam; 15 per cent unrubbed fibers; 1 per cent rubbed fibers.

C2 - - 135 centimeters; dark gray (2.5Y 4/1) silt loam. 
Canaan Valley National Wildlife Refuge, Davis, Tucker County, West Virginia

6 June 2014

Profile 1.14, Terric Haplohemist

Location: $39.13110,-79.38580$

Compiled by M. Schaney, C. Schaney, and R. Fedders

Oi1 - - 0 to 9 centimeters; reddish brown (5YR 4/4) unrubbed fibric peat; 100 per cent unrubbed fibers; 98 per cent rubbed fibers; clear smooth boundary.

Oi2 - - 9 to 23 centimeters; black (10YR 2/1) unrubbed sapric muck; 15 per cent unrubbed fibers; 2 per cent rubbed fibers; charcoal at $23 \mathrm{~cm}$.

Oa - - 23 to 56 centimeters; black (10YR 2/1) unrubbed sapric muck; 20 per cent unrubbed fibers; 1 per cent rubbed fibers; $20 \%$ charcoal.

Oe - - 56 to 65 centimeters; dark reddish brown (5YR 3/3) unrubbed hemic mucky peat, 90 per cent unrubbed fibers; 35 per cent rubbed fibers, clear smooth boundary.

C- - 65 to 94 centimeters; very dark brown (7.5YR 2.5/2) silt loam, clear smooth boundary.

C - - 94 to 110 centimeters; grayish brown (2.5YR 5/2) silty clay loam; 5 per cent fibers.

C - - 110 to 113 centimeters; gray (2.5Y 5/1) silt. 
Canaan Valley National Wildlife Refuge, Davis, Tucker County, West Virginia

6 June 2014

Profile 1.16, Terric Haplosaprist

Location: $39.13050,-79.38700$

Compiled by M. Schaney, C. Schaney, and R. Fedders

Oi1 - - 0 to 18 centimeters; reddish brown (5YR 4/4) unrubbed fibric peat; 100 per cent unrubbed fibers; 98 per cent rubbed fibers; clear smooth boundary.

Oa1 - - 18 to 32 centimeters; black (10YR 2/1) unrubbed sapric muck; 15 per cent unrubbed fibers; 2 per cent rubbed fibers; common fine roots.

Oa2 - - 32 to 40 centimeters; black (10YR 2/1) unrubbed sapric muck with silty clay; 10 per cent unrubbed fibers; 1 per cent rubbed fibers.

C - - 40 to 70 centimeters; dark yellowish brown (10YR 4/4) silt loam; gradual boundary.

Cg1 - - 70 to 120 centimeters; grayish brown (2.5Y 5/2) silt loam; gradual boundary.

Cg2 - - 120 to 131 centimeters; dark reddish gray (5YR 4/2) silt clay loam. 
Canaan Valley National Wildlife Refuge, Davis, Tucker County, West Virginia

21 March 2014

Profile 1.17, Typic Haplosaprist

Location: 39.13200, -79.38410

Compiled by M. Schaney, J. Teets, J. Thompson, J.S. Kite, M. Purtill, and C. Patterson

- -15 to 0 centimeters; living sphagnum

Oi - - 0 to 43 centimeters; very dark brown (10YR 2/2) unrubbed fibric peat; von Post 3.

Oa - - 43 to 99 centimeters; 85 per cent black (10YR 2/1) unrubbed sapric muck, and 15 per cent reddish black (2.5YR 2.5/1) unrubbed sapric material; clear smooth boundary.

Oe - - 99 to 152 centimeters; very dark brown (7.5YR 2.5/2) unrubbed hemic sedge mucky peat, with 30 per cent sedge fibers that disappear after first rub; clear smooth boundary.

Cg1 - 152 to 167 centimeters; dark grayish brown (2.5Y 4/2) silt loam; massive; clear smooth boundary.

Cg2 - - 167 to 175 centimeters; dark grayish brown (2.5Y 4/2) very fine sandy loam; massive; clear smooth boundary.

C1 - 175 to 183 centimeters; reddish brown (5YR 4/3) very fine sandy loam; massive; 1 per cent, small, rounded, carbonate gravel; clear smooth boundary.

C2 - 183 to 203 centimeters; dark reddish brown (2.5YR 3/3) silty clay; massive; carbonate crust; highly reactive. 
Canaan Valley National Wildlife Refuge, Davis, Tucker County, West Virginia

21 March 2014

Profile 1.18, Typic Haplohemist

Location: $39.13300,-79.38300$

Compiled by M. Schaney, J. Teets, J. Thompson, M. Purtill, and C. Patterson

-10 to 0 centimeters; living sphagnum

Oi - - 0 to 30 centimeters; very dark brown (10YR 2/2) unrubbed fibric peat.

Oa - - 30 to 68 centimeters; black (5YR 2.5/1) unrubbed sapric muck; clear smooth boundary.

Oe - - 68 to 135 centimeters; very dark brown (7.5YR 2.5/2) unrubbed hemic mucky peat, with 80 per cent sedge fibers; clear smooth boundary.

- - 135 to 177 centimeters; unsampled organic material

Cg - - 177 to 178 centimeters; greenish gray (10Y 6/1) very fine loamy sand.

C - - 178 to 182 centimeters; greenish black (10BG 2.5/1) clay loam; massive; 20 per cent brown (7.5YR 5/3), slightly reactive, lenses. 
Canaan Valley National Wildlife Refuge, Davis, Tucker County, West Virginia

7 May 2014

Profile 1.19, Hemic Haplosaprist

Location: 39.13277, -79.38363

Compiled by M. Schaney, M. Purtill, J. Burkhart, K. Yost, T. Talbolt, and R. Fedders

Oi1 - - 0 to 6 centimeters; yellowish red (5YR 4/6) unrubbed fibric peat; 100 per cent unrubbed fibers; 95 per cent rubbed brown (5YR 2.5/2) fibers; von Post scale 2; field $\mathrm{pH} 4.2$.

Oi2 - - 6 to 17 centimeters; dark reddish brown (5YR 3/4) unrubbed fibric peat; 95 per cent unrubbed fibers; 90 per cent rubbed brown (7.5YR 2.5/1) fibers; von Post scale 2; field pH 4.2.

Oa1 - 17 to 44 centimeters; black (10YR 2/1) unrubbed sapric muck; 10 per cent unrubbed fibers; 3 rubbed fibers; von Post scale 7; field $\mathrm{pH}$ 4.5.

Oa2 - - 44 to 66 centimeters; black (10YR 2/1) unrubbed sapric muck with charcoal, 15 per cent unrubbed fibers; 5 per cent rubbed fibers; gradual boundary; field $\mathrm{pH} 4.6$.

Oe1 - - 66 to 92 centimeters; dark reddish brown (5YR 3/3) unrubbed hemic mucky peat, 40 per cent unrubbed fibers; 30 per cent (5YR 2.5/1) rubbed fibers; field $\mathrm{pH} 4.5$.

Oe2 - - 92 to 115 centimeters; dark brown (7.5YR 3/2) unrubbed hemic mucky peat with charcoal, 60 per cent unrubbed fibers; 30 per cent rubbed fibers; field $\mathrm{pH} 4.7$. 
Canaan Valley National Wildlife Refuge, Davis, Tucker County, West Virginia

7 May 2014

Profile 1.20, Hemic Haplosaprist

Location: $39.13297,-79.38390$

Compiled by M. Schaney, M. Purtill, J. Burkhart, K. Yost, T. Talbolt, and R. Fedders

Oi1 - - 0 to 14 centimeters; dark reddish brown (2.5YR 3/4) unrubbed fibric peat; 100 per cent unrubbed fibers; 98 per cent rubbed dusky red (2.5YR 3/2) fibers; Von Post scale 2; field pH 4.2.

Oi2 - - 14 to 25 centimeters; reddish black (2.5YR 2.5/1) fibric peat; 90 per cent unrubbed fibers; 80 per cent rubbed fibers; Von Post scale 2; field $\mathrm{pH} 4.7$.

Oa1 - - 25 to 49 centimeters; reddish black (2.5YR 2.5/1) sapric muck; 10 per cent unrubbed fibers; 7 rubbed fibers; Von Post scale 7; field $\mathrm{pH} 4.7$.

Oa2 - - 49 to 68 centimeters; black (7.5YR 2.5/1) unrubbed sapric muck with charcoal, 30 per cent unrubbed fibers; 5 per cent rubbed fibers; gradual boundary; field $\mathrm{pH} 5$.

Oe1 - - 68 to 135 centimeters; dark brown (7.5YR 3/2) unrubbed hemic mucky peat, 75 per cent unrubbed fibers; 35 per cent very dark brown (7.5YR 2.5/2) rubbed fibers; field pH 5.

Oe2 - - 135 to 146 centimeters; dark brown (7.5YR 3/3) unrubbed hemic mucky peat with 5 per cent very fine to fine sand coated with organics; 85 per cent unrubbed fibers; 40 per cent rubbed fibers; field $\mathrm{pH} 5.25$. 
Canaan Valley National Wildlife Refuge, Davis, Tucker County, West Virginia

7 May 2014

Profile 1.21, Hemic Haplosaprist

Location: $39.13313,-79.38397$

Compiled by M. Schaney, M. Purtill, J. Burkhart, K. Yost, T. Talbolt, and R. Fedders

Oi1 - - 0 to 10 centimeters; yellowish red (5YR 4/6) unrubbed fibric peat; 100 per cent unrubbed fibers; 98 per cent rubbed dark reddish brown (5YR 3/3) fibers; Von Post scale 2; field pH 4.7.

Oi2 - - 10 to 19 centimeters; reddish black (2.5YR 2.5/1) unrubbed fibric peat; 95 per cent unrubbed fibers; 90 per cent rubbed black (5YR 2.5/1) fibers; Von Post scale 2; field pH 4.7.

Oa1 - - 19 to 33 centimeters; 15 per cent reddish black (2.5YR 2.5/1) unrubbed sapric muck; 7 rubbed fibers; Von Post scale 7; viscous consistence; field $\mathrm{pH} 4.7$.

Oa2 - - 33 to 48 centimeters; dark reddish brown (5YR 2.5/2) unrubbed sapric muck with charcoal, 20 per cent unrubbed fibers; 7 per cent rubbed fibers; field $\mathrm{pH} 4.7$.

Oa3 - - 48 to 72 centimeters; very dusky red (2.5YR 2.5/2) unrubbed sapric muck, 50 per cent unrubbed fibers; at 56 centimeters thin charcoal lens; 7 per cent reddish black (2.5YR 2.5/1) rubbed fibers; field $\mathrm{pH} 4.7$.

Oe - - 72 to 145 centimeters; dark brown (7.5YR 3/2) unrubbed hemic mucky peat; 65 per cent unrubbed fibers; 30 per cent rubbed fibers; field $\mathrm{pH} 4.7$. 
Canaan Valley National Wildlife Refuge, Davis, Tucker County, West Virginia

9 August 2014

Profile 1.50, Hemic Haplosaprist

Location: $39.13286,-79.38428$

Compiled by M. Schaney, S. Marsh, and N. Funk

Described in Lab on 18 December 2014

Oi - - 0 to 20 centimeters; dark reddish brown (2.5YR 3/4) fibric peat; 100 per cent unrubbed fibers; 85 per cent rubbed fibers; von Post scale 2; removed in field.

Oa1 - - 20 to 37 centimeters; black (10YR 2/1) unrubbed sapric muck; 10 per cent unrubbed fibers; 5 per cent rubbed fibers; von Post scale 7.

Oa2 - - 37 to 65 centimeters; very dark brown (10YR 2/2) unrubbed sapric muck; common fine roots; 20 per cent unrubbed fibers; 5 per cent rubbed fibers; von Post scale 6; gradual boundary.

Oe1 - - 65 to 116 centimeters; very dark brown (7.5YR 2.5/3) unrubbed hemic sedge mucky peat; 60 per cent unrubbed fibers; 25 per cent rubbed fibers; von Post scale 4; gradual boundary.

Oe2 - - 116 to 174 centimeters; very dark brown (7.5YR 2.5/2) unrubbed hemic mucky peat; 50 per cent unrubbed fibers; 20 per cent rubbed fibers; von Post scale 5, wet particle board/ wet sawdust; very abrupt boundary.

Cg - - 174 to 178 centimeters; dark gray (2.5Y 4/1) fine to medium sand. 
Canaan Valley National Wildlife Refuge, Davis, Tucker County, West Virginia

9 August 2014

Profile 1.60, Hemic Haplosaprist, Full Core Sample

Location: $39.13115,-79.38404$

Compiled by M. Schaney, S. Marsh, and N. Funk

Described in Lab

Oi - - 0 to 28 centimeters; dark reddish brown (2.5YR 3/4) fibric peat; 100 per cent unrubbed fibers; 85 per cent rubbed fibers; von Post scale 2; removed in field.

Fiber Content 20\%: $\underline{\text { Hemic }}$

Pyrophosphate Color 10YR 5/4, 10YR 6/4: Sapric

Lab pH 2.97

Mineral Content $\mathbf{= 0 . 6 1 \%}$

Organic Content $=\mathbf{9 9 . 3 9 \%}$

Oa1 - - 28 to 50 centimeters; black (10YR 2/1) unrubbed sapric muck; 10 per cent unrubbed fibers; 5 per cent rubbed fibers; von Post scale 7, crumbly consistence.

Fiber Content 2\%: $\underline{\text { Sapric }}$

Pyrophosphate Color 10YR 8/3, 10YR 3/3: Fibric and Sapric

Lab pH 2.85

Mineral Content $=9 \%$

Organic Content $=\mathbf{9 1 \%}$

Oa2 - - 50 to 80 centimeters; very dark brown (10YR 2/2) unrubbed sapric muck; 20 per cent unrubbed fibers; 5 per cent rubbed fibers; von Post scale 6; gradual boundary.

Fiber Content 2\%: Sapric

Pyrophosphate Color 10YR 4/3, 10YR 3/3: Sapric

Lab pH 3.0

Mineral Content $=\mathbf{1 2 . 2 4 \%}$

Organic Content $=\mathbf{8 7 . 7 6} \%$

Oe1 - - 80 to 105 centimeters; very dark brown (7.5YR 2.5/3) unrubbed hemic sedge mucky peat; 60 per cent unrubbed fibers; 25 per cent rubbed fibers; von Post scale 4; gradual boundary. Fiber Content 8\%: Sapric

Pyrophosphate Color 10YR 5/4, 10YR 3/6: $\underline{\text { Sapric }}$

Lab pH 3.13

Mineral Content $=\mathbf{1 0} \%$

Organic Content $=\mathbf{9 0 \%}$

Oe2 - - 105 to 137 centimeters; very dark brown (7.5YR 2.5/2) unrubbed hemic mucky peat; 50 per cent unrubbed fibers; 20 per cent rubbed fibers; von Post scale 5, wet particle board; very abrupt boundary.

Fiber Content 12\%: Sapric

Pyrophosphate Color 10YR 6/4: $\underline{\text { Sapric }}$

Lab pH 3.17

Mineral Content $=\mathbf{3 4 . 1 1} \%$ 


\section{Organic Content $\mathbf{= 6 5 . 8 9 \%}$}

Cg - - 137 to 140 centimeters; grayish brown (2.5Y 5/2) fine sandy loam. Lab pH 3.4 
Canaan Valley National Wildlife Refuge, Davis, Tucker County, West Virginia

19 May 2015

Profile 1.70 - Terric Haplosaprist, in GPR survey

Location: $39.13354,-79.38383$

Compiled by M. Schaney, A. Moore, and W. Tuttle

Oi - - 0 to 20 centimeters; yellowish red (5YR 5/8) fibric peat; 100 per cent unrubbed fibers; 95 per cent rubbed fibers; von Post scale 2.

Oa1 - - 20 to 27 centimeters; black (5YR 2.5/1) unrubbed sapric muck; 10 per cent unrubbed fibers; 2 per cent rubbed fibers; von Post scale 7 .

Oa2 - - 27 to 53 centimeters; black (10YR 2/1) unrubbed sapric muck with $40 \%$ silt loam; 10 per cent unrubbed fibers; 5 per cent rubbed fibers; von Post scale 8.

Oa3 - - 53 to 88 centimeters; dark brown (7.5YR 3/3) unrubbed sapric muck; 40 per cent unrubbed fibers; 10 per cent rubbed fibers; von Post scale 5.

C - - 88 to 105 centimeters; dark olive brown (2.5Y 3/3) silty clay; abrupt boundary.

Cg - - 105 to 120 centimeters; gray (2.5Y 5/1) silty clay (higher percentage of clay); dense. 
Canaan Valley National Wildlife Refuge, Davis, Tucker County, West Virginia

1 June 2015

Profile 1.80, Terric Haplosaprist

Location: 39.13300, -79.38400

Compiled by M. Schaney, J. Bernosky, H. Jewell, and E. Davis

Oi - - 0 to 20 centimeters; yellowish red (5YR 4/6) fibric peat; 100 per cent unrubbed fibers; 98 per cent rubbed fibers; von Post scale 2.

Oa - 20 to 27 centimeters; black (7.5YR 2.5/1) unrubbed sapric muck; 10 per cent unrubbed fibers; 1 per cent rubbed fibers; von Post scale 7.

Oe - - 27 to 31 centimeters; dark brown (7.5YR 3/3) unrubbed hemic mucky peat; 40 per cent unrubbed fibers; 25 per cent rubbed fibers; von Post scale 4.

Oa - 31 to 61 centimeters; black (7.5YR 2.5/1) unrubbed sapric muck with some clay; 15 per cent unrubbed fibers; 2 per cent rubbed fibers; von Post scale 7.

Cg - - 61 to 67 centimeters; gray (5Y 5/1) silty clay. 
Canaan Valley National Wildlife Refuge, Davis, Tucker County, West Virginia

1 June 2015

Profile 1.81, Terric Haplosaprist

Location: 39.13283, -79.38276

Compiled by M. Schaney, J. Bernosky, H. Jewell, and E. Davis

Oi - - 0 to 30 centimeters; yellowish red (5YR 4/6) fibric peat; 100 per cent unrubbed fibers; 98 per cent rubbed fibers; von Post scale 2.

Bulk Density 0.048 Fibric

Oa1 - - 30 to 64 centimeters; black (7.5YR 2.5/1) unrubbed sapric muck; 7 per cent unrubbed fibers; 2 per cent rubbed fibers; von Post scale 7.

Bulk Density 0.152 Hemic

Oa2 - - 64 to 116 centimeters; dark brown (10YR 3/3) unrubbed sapric muck; 40 per cent unrubbed fibers; 5 per cent rubbed fibers; von Post scale 6 .

Bulk Density 0.161 $\underline{\text { Hemic }}$

C1 - 116 to 123 centimeters; olive gray (5Y 5/2) clay loam; abrupt boundary.

C2 - - 123 to 124 centimeters; olive gray (5Y 5/2) loam. 
Canaan Valley National Wildlife Refuge, Davis, Tucker County, West Virginia

1 June 2015

Profile 1.82, Terric Haplohemist

Location: $39.13221,-79.38553$

Compiled by M. Schaney, J. Bernosky, H. Jewell, and E. Davis

Oi - - 0 to 20 centimeters; dark yellowish brown (10YR 4/6) fibric peat; 95 per cent unrubbed fibers; 92 per cent rubbed fibers; von Post scale 2.

Bulk Density 0.016 Fibric

Oa - - 20 to 59 centimeters; black (10YR 2/1) unrubbed sapric muck; 12 per cent unrubbed fibers; 1 per cent rubbed fibers; von Post scale 7.

Oe1 - - 59 to 77 centimeters; very dark brown (10YR 2/2) unrubbed hemic mucky peat; 20 per cent unrubbed fibers; 5 per cent rubbed fibers; von Post scale 6.

Bulk Density $0.157 \underline{\text { Hemic }}$

Oe2 - - 77 to 103 centimeters; very dark brown (10YR 2/2) unrubbed hemic mucky peat; 40 per cent unrubbed fibers; 10 per cent rubbed fibers; von Post scale 5.

Bulk Density 0.126 Hemic

Cg - - 103 to 125 centimeters; very dark grayish brown (2.5Y 3/2) silty clay with 25 per cent organic matter (twigs); diffuse boundary.

Bulk Density 0.359 Sapric

128-130cm Radiocarbon age $12810 \pm 40$ (median cal yr BP 15258) - depth measured off lab sample core

C - - 125 to 135 centimeters; olive (5Y 4/3). 
Canaan Valley National Wildlife Refuge, Davis, Tucker County, West Virginia

22 June 2015

Profile 1.83, Entisol

Location: $39.12887,-79.38115$

Compiled by M. Schaney, J. Bernosky, and M. Eltahir

Oa - - 0 to 8 centimeters; black (10YR 2/1) sapric muck; 15 per cent unrubbed fibers; 2 per cent rubbed fibers; von Post scale 7.

Cg1 - - 8 to 17 centimeters; very dark grayish brown (10YR 3/2) loam; clear boundary.

Cg2 - - 17 to 40 centimeters; dark yellowish brown (10YR 4/4) silt loam; massive, with redox. 
Canaan Valley National Wildlife Refuge, Davis, Tucker County, West Virginia

22 June 2015

Profile 1.84, Entisol

Location: 39.12974, -79.38166

Compiled by M. Schaney, J. Bernosky, and M. Eltahir

Oi - - 0 to 8 centimeters; dark yellowish brown (10YR 3/4) fibric peat; 95 per cent unrubbed fibers; 80 per cent rubbed fibers; von Post scale 3.

Oa - - 0 to 8 centimeters; black (10YR 2/1) sapric muck; 10 per cent unrubbed fibers; 5 per cent rubbed fibers; von Post scale 8.

C - - 8 to 17 centimeters; dark brown (10YR 3/3) loamy sand; massive. 
Canaan Valley National Wildlife Refuge, Davis, Tucker County, West Virginia

22 June 2015

Profile 1.85, Entisol

Location: $39.13008,-79.38198$

Compiled by M. Schaney, J. Bernosky, and M. Eltahir

Oi - - 0 to 16 centimeters; very dark brown (10YR 2/2) fibric peat; 95 per cent unrubbed fibers;

80 per cent rubbed fibers; von Post scale 2.

Fiber content $48 \%$ Fibric

Pyrophosphate Color 10Y 8/1 Fibric

Lab pH 2.8

Mineral Content $=9.41 \%$

Organic Content $=\mathbf{9 0 . 5 9 \%}$

A - - 16 to 27 centimeters; black (10YR 2/1) silt loam; medium granular structure.

Fiber content $4 \%$ Sapric

Pyrophosphate Color 10YR 3/2, 10YR 4/3 $\underline{\text { Sapric }}$

Lab pH 3.1

Mineral Content $\mathbf{= 5 9 . 2 9 \%}$

Organic Content $\mathbf{=} \mathbf{4 0 . 7 1 \%}$

BC - - 27 to 38 centimeters; light gray (7.5YR 7/1) sandy loam; very weak platy structure.

Lab pH 2.95

Mineral Content $=\mathbf{9 7 . 3 6} \%$

Organic Content $\mathbf{2} \mathbf{2 . 6 4 \%}$

C - - 38 to 54 centimeters; light gray (7.5YR 7/1) loam with strong brown (7.5YR 5/8) redox concretions; massive.

Lab pH 3.13

Mineral Content $=\mathbf{9 8 . 2 6} \%$

Organic Content $\mathbf{= 1 . 7 4 \%}$ 
Canaan Valley National Wildlife Refuge, Davis, Tucker County, West Virginia

23 June 2015

Profile 1.86, Hemic Haplosaprist

Location: $39.13230,-79.38382$

Compiled by M. Schaney, J. Bernosky, E. Davis, and M. Eltahir

Oi - - 0 to 5 centimeters; reddish brown (5YR 4/4) unrubbed fibric peat; 100 per cent unrubbed fibers; 90 per cent rubbed fibers; clear smooth boundary; von Post scale 2.

$2-4 \mathrm{~cm}$ Radiocarbon age $1225 \pm 30$ (median cal yr BP 1153)

Oa - - 5 to 64 centimeters; black (7.5YR 2.5/1) unrubbed sapric muck; 15 per cent unrubbed fibers; 5 per cent rubbed fibers; von Post scale 7.

Bulk Density $0.22 \mathrm{~g} / \mathrm{cm}^{3} \underline{\text { Sapric }}$

Fiber content $8 \%$ Sapric

Pyrophosphate Color 10YR 4/4, 10YR 4/4 $\underline{\text { Sapric }}$

Laboratory pH 2.87

Mineral Content $=\mathbf{5 . 7 0 \%}$

Organic Content $=\mathbf{9 4 . 3 0} \%$

40-42cm Radiocarbon age $7880 \pm 35$ (median cal yr BP 8675)

$59-61 \mathrm{~cm}$ Radiocarbon age $9600 \pm 30$ (median cal yr BP 10928)

Oe - - 64 to 130 centimeters; dark brown (7.5YR 3/3) unrubbed hemic mucky peat; 40 per cent unrubbed fibers; 20 per cent rubbed fibers; von Post scale 4/5.

Bulk Density $0.11 \mathrm{~g} / \mathrm{cm}^{3}$ Hemic

Fiber content $20 \%$ Hemic

Pyrophosphate Color 10YR 7/2 Fibric, 10YR 7/4 $\underline{\text { Sapric }}$

Laboratory pH 3.2

Mineral Content $=\mathbf{7 . 1 0} \%$

Organic Content $\mathbf{= 9 2 . 9 0 \%}$

86-88cm Radiocarbon age $10475 \pm 35$ (median cal yr BP 12451)

$100-102 \mathrm{~cm}$ Radiocarbon age $10635 \pm 30$ (median cal yr BP 12621)

$127-129 \mathrm{~cm}$ Radiocarbon age $13155 \pm 40$ (median cal yr BP 15807)

Cg - - 130 to 133 centimeters; light gray (7.5YR 7/1) sand; massive. 
Canaan Valley National Wildlife Refuge, Davis, Tucker County, West Virginia

23 June 2015

Profile 1.87, Entisol

Location: $39.13417,-79.38454$

Compiled by M. Schaney, J. Bernosky, E. Davis, and M. Eltahir

Oi - - 0 to 13 centimeters; very dark brown (7.5YR 2.5/3) fibric peat; 95 per cent unrubbed fibers; 80 per cent rubbed fibers; von Post scale 2.

Fiber content $24 \%$ Hemic

Laboratory pH 3.55

Mineral Content $=\mathbf{5 . 1 7 \%}$

Organic Content $=\mathbf{9 4 . 8 3 \%}$

A - - 13 to 28 centimeters; black (5YR 2.5/1) sandy clay loam; large strong granular structure.

Laboratory pH 3.47

Mineral Content $=\mathbf{7 9 . 7 3 \%}$

Organic Content $\mathbf{= 2 0 . 2 7 \%}$

Bgt - - 28 to 42 centimeters; strong brown (7.5YR 5/8) silty clay with very dark brown (7.5YR 2.5/2) redox depletions; subangular blocky structure.

Laboratory pH 3.19

Mineral Content $=\mathbf{8 0 . 0 4 \%}$

Organic Content $\mathbf{= 1 9 . 9 6 \%}$

Cg - - 42 to 53 centimeters; strong brown (7.5YR 5/8) silty clay with grayish brown (2.5YR 5/2) redox depletions; massive.

Laboratory pH 3.59

Mineral Content $=\mathbf{9 5 . 3 1 \%}$

Organic Content $\mathbf{=} \mathbf{4 . 6 9 \%}$ 
Canaan Valley National Wildlife Refuge, Davis, Tucker County, West Virginia

21 October 2016

Profile 1.88, Hemic Haplosaprist

Location: $39.13200,-79.38500$

Compiled by M. Schaney, and SEFOP team

Oi - - 0 to 31 centimeters; dark reddish brown (2.5YR 2.5/3) fibric peat; 100 per cent unrubbed fibers; 99 per cent rubbed fibers; von Post scale 2.

Oa1 - - 31 to 48 centimeters; black (10YR 2/1) unrubbed sapric muck; 5 per cent unrubbed fibers; 1 per cent rubbed fibers; von Post scale 8.

Oa2 - - 48 to 77 centimeters; black (7.5YR 2.5/1) unrubbed sapric muck; 35 per cent unrubbed fibers; 5 per cent rubbed fibers; von Post scale 7.

Oe - - 77 to 106 centimeters; very dark brown (5YR 2.5/2) unrubbed hemic mucky peat; 65 per cent unrubbed fibers; 35 per cent rubbed fibers; von Post scale 5.

Oa - - 106 to 142 centimeters; dark brown (7.5YR 3/3) unrubbed sapric muck; 20 per cent unrubbed fibers; 5 per cent rubbed fibers; von Post scale 6. 
Canaan Valley National Wildlife Refuge, Davis, Tucker County, West Virginia

24 March 2015

Profile 2.01, Entisol

Location: 39.13836, - 79.36923

Compiled by M. Schaney, and Z. Haidar

Oi - - 0 to 15 centimeters; dark brown (7.5YR 3/4) fibric sphagnum peat; 100 per cent unrubbed fibers; 85 per cent rubbed fibers; von Post scale 2.

Oa - 15 to 38 centimeters; black (10YR 2/1) sapric muck; 7 per cent unrubbed fibers; 2 per cent rubbed fibers; von Post scale 8.

C - - 38 to 47 centimeters; very dark grayish brown (10YR 3/2) clay. 
Canaan Valley National Wildlife Refuge, Davis, Tucker County, West Virginia

24 March 2015

Profile 2.02, Terric Haplosaprist

Location: $39.13953,-79.37124$

Compiled by M. Schaney, and Z. Haidar

Oi - - 0 to 5 centimeters; reddish brown (5YR 4/4) fibric sphagnum peat; 100 per cent unrubbed fibers; 95 per cent rubbed fibers; von Post scale 2.

Oa1 - 5 to 23 centimeters; black (10YR 2/1) sapric muck; 10 per cent unrubbed fibers; 2 per cent rubbed fibers; von Post scale 8.

Oa2 - - 23 to 47 centimeters; black (10YR 2/1) sapric muck; 30 per cent unrubbed fibers; 10 per cent rubbed fibers; von Post scale 7.

Oa3- - 47 to 60 centimeters; very dark grayish brown (10YR 3/2) sapric muck with silty clay; 30 per cent unrubbed fibers; 15 per cent rubbed fibers. 
Canaan Valley National Wildlife Refuge, Davis, Tucker County, West Virginia

24 March 2015

Profile 2.03, Entisol

Location: 39.14100, -79.37200

Compiled by M. Schaney, and Z. Haidar

Oi - - 0 to 12 centimeters; reddish brown (5YR 4/4) fibric sphagnum peat; 100 per cent unrubbed fibers; 95 per cent rubbed fibers; von Post scale 2.

Cg - - 12 to 22 centimeters; dark gray (7.5YR 4/1) clay loam. 
Canaan Valley National Wildlife Refuge, Davis, Tucker County, West Virginia

24 March 2015

Profile 2.04, Terric Haplosaprist

Location: 39.14000, -79.37300

Compiled by M. Schaney, and Z. Haidar

Oi - - 0 to 5 centimeters; reddish brown (5YR 4/4) fibric sphagnum peat; 100 per cent unrubbed fibers; 90 per cent rubbed fibers; von Post scale 2.

Oa1 - - 5 to 37 centimeters; black (10YR 2/1) sapric muck; 30 per cent unrubbed fibers; 10 per cent rubbed fibers; von Post scale 7.

Oa2 - - 37 to 60 centimeters; black (10YR 2/1) sapric muck; 40 per cent unrubbed fibers; 15 per cent rubbed fibers; von Post scale 7.

Oa3 - - 60 to 75 centimeters; very dark grayish brown (10YR 3/2) sapric muck with silty clay; 30 per cent unrubbed fibers; 15 per cent rubbed fibers. 
Canaan Valley National Wildlife Refuge, Davis, Tucker County, West Virginia

24 March 2015

Profile 2.05, Terric Haplosaprist

Location: 39.139084, -79.372111

Compiled by M. Schaney, and Z. Haidar

Oi - - 0 to 5 centimeters; reddish brown (5YR 4/4) fibric sphagnum peat; 100 per cent unrubbed fibers; 90 per cent rubbed fibers; von Post scale 2.

Oa1 - - 5 to 14 centimeters; black (10YR 2/1) sapric muck; 10 per cent unrubbed fibers; 5 per cent rubbed fibers; von Post scale 8.

Oa2 - - 14 to 57 centimeters; black (10YR 2/1) sapric muck; 15 per cent unrubbed fibers; 5 per cent rubbed fibers; von Post scale 7.

Oa3 - - 57 to 82 centimeters; dark brown (10YR 3/3) sapric muck; 20 per cent unrubbed fibers; 15 per cent rubbed fibers; von Post scale 6.

Oe - - 82 to 120 centimeters; dark brown (7.5YR 3/4) hemic mucky peat; 40 per cent unrubbed fibers; 30 per cent rubbed fibers; von Post scale 4.

$119-121 \mathrm{~cm}$ Radiocarbon age $15045 \pm 10$ (median cal yr BP 18284)

Cg - - 120 to 150 centimeters; greenish gray (10Y 5/1) clay loam. 
Canaan Valley National Wildlife Refuge, Davis, Tucker County, West Virginia

24 March 2015

Profile 2.06, Typic Haplohemist

Location: 39.13800, -79.37200

Compiled by M. Schaney, and Z. Haidar

Oi - - 0 to 5 centimeters; reddish brown (5YR 4/4) fibric sphagnum peat; 100 per cent unrubbed fibers; 90 per cent rubbed fibers; von Post scale 2.

Oa1 - - 5 to 17 centimeters; very dark grayish brown (10YR 3/2) sapric sedge muck; 30 per cent unrubbed fibers; 10 per cent rubbed fibers; von Post scale 6.

Oa2 - - 17 to 50 centimeters; black (10YR 2/1) sapric muck; 15 per cent unrubbed fibers; 5 per cent rubbed fibers; von Post scale 7.

Oe1 - 50 to 100 centimeters; dark brown (10YR 3/3) hemic sedge mucky peat; 40 per cent unrubbed fibers; 20 per cent rubbed fibers; von Post scale 5.

Oe2 - - 100 to 170 centimeters; dark brown (7.5YR 3/4) hemic mucky peat; 60 per cent unrubbed fibers; 25 per cent rubbed fibers; von Post scale 4; gradual transition.

Cg - 170 to 190 centimeters; greenish gray (10Y 5/1) clay loam. 
Canaan Valley National Wildlife Refuge, Davis, Tucker County, West Virginia

24 March 2015

Profile 2.07, Terric Haplosaprist

Location: $39.13654,-79.37278$

Compiled by M. Schaney, and Z. Haidar

Oi - - 0 to 7 centimeters; yellowish brown (10YR 5/6) fibric sphagnum peat; 70 per cent unrubbed fibers; 50 per cent rubbed fibers; von Post scale 3.

Oa1 - - 7 to 20 centimeters; black (10YR 2/1) sapric sedge muck; 5 per cent unrubbed fibers; 0 per cent rubbed fibers; von Post scale 8.

Oa2 - - 20 to 46 centimeters; black (10YR 2/1) sapric muck; 15 per cent unrubbed fibers; 10 per cent rubbed fibers; von Post scale 7.

Oa3 - - 46 to 108 centimeters; dark yellowish brown (10YR 3/4) sapric muck; 40 per cent unrubbed fibers; 10 per cent rubbed fibers; von Post scale 6.

Cg - - 108 to 110 centimeters; grayish brown (10YR 5/2) silt loam. 
Canaan Valley National Wildlife Refuge, Davis, Tucker County, West Virginia 23 July 2015

Profile 2.08, Terric Haplosaprist

Location: $39.13577,-79.37446$

Compiled by M. Schaney, R. Fields, H. Black, M. Gunderson, J. Hardy, and J. Johnson

Oi - - 0 to 13 centimeters; yellowish brown (10YR 5/4) fibric sphagnum peat; 80 per cent unrubbed fibers; 75 per cent rubbed fibers; von Post scale 3.

Oa1 - - 13 to 39 centimeters; black (10YR 2/1) sapric muck; 1 per cent unrubbed fibers; 0 per cent rubbed fibers; von Post scale 8.

Fiber Content 20\%: $\underline{\text { Hemic }}$

Pyrophosphate Color 10YR 3/1, 10YR 4/3: Sapric

Lab pH 2.96

Mineral Content $=9 \%$

Organic Content $=\mathbf{9 1 \%}$

Oa2 - - 39 to 62 centimeters; very dark brown (10YR 2/2) sapric muck; 20 per cent unrubbed fibers; 5 per cent rubbed fibers; von Post scale 7.

Fiber Content 8\%: Sapric

Pyrophosphate Color 10YR 5/4, 10YR 4/6: Sapric

Lab pH 2.93

Mineral Content $=\mathbf{2 4 \%}$

Organic Content $=\mathbf{7 6} \%$

Oa3 - - 62 to 80 centimeters; dark yellowish brown (10YR 3/4) sapric muck; 35 per cent unrubbed fibers; 20 per cent rubbed fibers; von Post scale 5.

Fiber Content 4\%: $\underline{\text { Sapric }}$

Pyrophosphate Color 10YR 5/6, 10YR 4/6: Sapric

Lab pH 3.09

Mineral Content $=26 \%$

Organic Content $=\mathbf{7 4 \%}$ 
Canaan Valley National Wildlife Refuge, Davis, Tucker County, West Virginia

23 July 2015

Profile 2.09, Terric Haplosaprist

Location: $39.13589,-79.37254$

Compiled by M. Schaney, R. Fields, H. Black, M. Gunderson, J. Hardy, and J. Johnson

Notes: No surface sphagnum; a different moss in a very thin layer. Dryer location.

Oa1 - - 0 to 40 centimeters; black (10YR 2/1) unrubbed sapric muck; 1 per cent unrubbed fibers; 0 per cent rubbed fibers; von Post scale 8; wet and soupy consistence.

Bulk Density $0.18 \mathrm{~g} / \mathrm{cm}^{3}$ : $\underline{\text { Sapric }}$

$15-17 \mathrm{~cm}$ Radiocarbon age $3550 \pm 35$ (median cal yr BP 3844)

Oa2 - - 40 to 70 centimeters; very dark brown (10YR 2/2) unrubbed sapric muck; 5 per cent unrubbed fibers; 0 per cent rubbed fibers; von Post scale 8; dry consistence.

Fiber Content 2\%: Sapric

Pyrophosphate Color 10YR 3/4, 10YR 3/6: $\underline{\text { Sapric }}$

Lab pH 3.01

$40-42 \mathrm{~cm}$ Radiocarbon age $8035 \pm 35$ (median cal yr BP 8909)

$65-67 \mathrm{~cm}$ Radiocarbon age $12455 \pm 45$ (median cal yr BP 14598)

Oa3 - - 70 to 109 centimeters; dark brown (10YR 3/3) unrubbed sapric muck; 35 per cent unrubbed fibers; 20 per cent rubbed fibers; von Post scale 5.

Bulk Density $0.27 \mathrm{~g} / \mathrm{cm}^{3}$ : $\underline{\text { Sapric }}$

Fiber Content 12\%: Sapric

Pyrophosphate Color 10YR 7/4, 10YR 4/6: Sapric

Lab pH 3.29

Mineral Content $=35 \%$

Organic Content $=65 \%$

$80-82 \mathrm{~cm}$ Radiocarbon age $12985 \pm 40$ (median cal yr BP 15528)

92-94cm Radiocarbon age $13225 \pm 40$ (median cal yr BP 15896)

Cg - - 109 to 120 centimeters; grayish brown (10YR 5/2) fine sandy loam.

Lab pH 3.29 
Canaan Valley National Wildlife Refuge, Davis, Tucker County, West Virginia

23 July 2015

Profile 2.10, Typic Haplosaprist

Location: $39.13729,-79.37213$

Compiled by M. Schaney, R. Fields, H. Black, M. Gunderson, J. Hardy, and J. Johnson

Oi - - 0 to 13 centimeters; yellowish brown (10YR 5/4) unrubbed fibric sphagnum peat; 80 per cent unrubbed fibers; 75 per cent rubbed fibers; von Post scale 3.

Oa1 - - 13 to 34 centimeters; black (10YR 2/1) unrubbed sapric muck; 5 per cent unrubbed fibers; 1 per cent rubbed fibers; von Post scale 7.

Pyrophosphate Color 10YR 5/4: Sapric

Lab pH 2.72

Oa2 - - 34 to 60 centimeters; very dark grayish brown (10YR 3/2) unrubbed sapric sedge muck; 40 per cent unrubbed fibers; 20 per cent rubbed fibers; von Post scale 4.

Bulk Density $(30-35 \mathrm{~cm}) 0.18 \underline{\text { Hemic}}$, and $(55-60 \mathrm{~cm}) 0.22 \mathrm{~g} / \mathrm{cm}^{3}$ : $\underline{\text { Sapric }}$

Fiber Content 16\%: $\underline{\text { Sapric }}$

Pyrophosphate Color 10YR 6/4, 10YR 6/4: Sapric

Lab pH 2.75

Mineral Content $=4 \%$

Organic Content $=96 \%$

Oa3 - - 60 to 90 centimeters; black (10YR 2/1) unrubbed sapric muck; 5 per cent unrubbed fibers; 1 per cent rubbed fibers; von Post scale 8.

Fiber Content 8\%: $\underline{\text { Sapric }}$

Pyrophosphate Color 10YR 5/4: $\underline{\text { Sapric }}$

Lab pH 2.95

Mineral Content $=14 \%$

Organic Content $=\mathbf{8 6} \%$

Oa4 - - 90 to 159 centimeters; dark brown (10YR 3/3) unrubbed sapric muck; 50 per cent unrubbed fibers; 25 per cent rubbed fibers; von Post scale 5.

Bulk Density $(90-95$ and $140-145 \mathrm{~cm}) 0.21 \mathrm{~g} / \mathrm{cm}^{3}$ : Sapric

Fiber Content 16\%: $\underline{\text { Sapric }}$

Pyrophosphate Color 10YR 5/4, 10YR 5/6: $\underline{\text { Sapric }}$

Lab pH 3.15

Mineral Content $=33 \%$

Organic Content $=67 \%$

Cg - - 159 to 163 centimeters; grayish brown (10YR 5/2)

Lab pH 3.41 
Canaan Valley National Wildlife Refuge, Davis, Tucker County, West Virginia

23 July 2015

Profile 2.11, Terric Haplosaprist

Location: $39.13853,-79.37293$

Compiled by M. Schaney, R. Fields, H. Black, M. Gunderson, J. Hardy, and J. Johnson

Oa1 - - 0 to 20 centimeters; black (10YR 2/1) unrubbed sapric muck; 20 per cent unrubbed fibers; 10 per cent rubbed fibers; von Post scale 6.

Fiber Content 40\%: Fibric/Hemic

Pyrophosphate Color 10YR 3/3, 10YR 3/3: Sapric

Lab pH 2.97

Mineral Content $=\mathbf{1 0} \%$

Organic Content $=\mathbf{9 0 \%}$

Oa2 - - 20 to 40 centimeters; black (7.5YR 2.5/1) unrubbed sapric sedge muck; 50 per cent unrubbed fibers; 30 per cent rubbed fibers; von Post scale 5.

Fiber Content 12\%: Sapric

Pyrophosphate Color 10YR 5/4, 10YR 5/6: $\underline{\text { Sapric }}$

Lab pH 3.07

Mineral Content $=4 \%$

Organic Content $=96 \%$

Oa3 - - 40 to 70 centimeters; very dark brown (10YR 2/2) unrubbed sapric muck; 45 per cent unrubbed fibers; 10 per cent rubbed fibers; von Post scale 7.

Fiber Content 2\%: $\underline{\text { Sapric }}$

Pyrophosphate Color 10YR 4/4, 10YR 3/3: Sapric

Lab pH 3.19

Mineral Content $=\mathbf{2 0} \%$

Organic Content $=\mathbf{8 0} \%$

Oa4 - - 70 to 100 centimeters; dark brown (10YR 3/3) unrubbed sapric muck; 35 per cent unrubbed fibers; 15 per cent rubbed fibers; von Post scale 6.

Pyrophosphate Color 10YR 5/6: $\underline{\text { Sapric }}$

Lab pH 3.28 
Canaan Valley National Wildlife Refuge, Davis, Tucker County, West Virginia

7 August 2014

Profile 3.01, Terric Haplosaprist

Location: $39.14272,-79.35528$, next to loan white pine, cotton grass vegetation

Compiled by M. Schaney and R. Fedders

Oi - - 0 to 18 centimeters; dark brown (7.5YR 3/4) unrubbed fibric peat; 100 per cent unrubbed fibers; 95 per cent rubbed fibers; von Post scale 2.

Oa1 - - 18 to 38 centimeters; black (10YR 2/1) unrubbed sapric muck; very soft and loose consistence; 5 per cent unrubbed fibers; 3 per cent rubbed fibers; von Post scale 8.

Oa2 - - 38 to 83 centimeters; black (10YR 2/1) unrubbed sapric muck; firmer than horizon above; 10 per cent unrubbed fibers; 3 per cent rubbed fibers; von Post scale 7; small traces of charcoal at 42 centimeters.

Oa3 - - 83 to 88 centimeters; black (10YR 2/1) unrubbed sapric muck with (7.5YR 5/1) gray clay; 0 per cent unrubbed fibers; 0 per cent rubbed fibers; von Post scale 8.

Oa4 - - 88 to 107 centimeters; black (10YR 2/1) unrubbed sapric muck; 15 per cent unrubbed fibers; 3 per cent rubbed fibers; von Post scale 7.

Oe - - 107 to 116 centimeters; dark brown (7.5YR 3/4) unrubbed hemic sedge material; 40 per cent unrubbed fibers; 18 per cent rubbed fibers; von Post scale 5; grading into clay.

Cg1 - - 116 to 132 centimeters; gray (10YR 5/1) clay; 15 per cent unrubbed fibers; 5 per cent rubbed fibers; charcoal lens at 122 centimeters.

Cg2 - - 132 to 154 centimeters; dark reddish gray (5YR 4/2) very fine sandy clay; very little organic matter. 
Canaan Valley National Wildlife Refuge, Davis, Tucker County, West Virginia

7 August 2014

Profile 3.02, Terric Haplosaprist

Location: 39.14232, -79.35720

Compiled by M. Schaney and R. Fedders

Oi - - 0 to 11 centimeters; dark brown (7.5YR 3/4) unrubbed fibric peat; 95 per cent unrubbed fibers; 80 per cent rubbed fibers; von Post scale 2; grass and rush fibers.

Oa1 - 11 to 25 centimeters; black (10YR 2/1) unrubbed sapric muck; very soft and loose consistence; 10 per cent unrubbed fibers; 5 per cent rubbed fibers; von Post scale 7.

Oa2 - - 25 to 50 centimeters; black (10YR 2/1) unrubbed sapric muck; 5 per cent unrubbed fibers; 3 per cent rubbed fibers; von Post scale 7.

Cg - - 50 to 60 centimeters; dark grayish brown (10YR 4/2) clay; no visible vegetation fibers. 
Canaan Valley National Wildlife Refuge, Davis, Tucker County, West Virginia

7 August 2014

Profile 3.03, Terric Haplosaprist

Location: $39.14235,-79.35689$

Compiled by M. Schaney and R. Fedders

Oi - - 0 to 9 centimeters; dark brown (7.5YR 3/4) unrubbed fibric peat; 95 per cent unrubbed fibers; 80 per cent rubbed fibers; von Post scale 2.

Oa - - 9 to 21 centimeters; black (10YR 2/1) unrubbed sapric muck; 8 per cent unrubbed fibers; 5 per cent rubbed fibers; von Post scale 8; not wet.

Oe - - 21 to 31 centimeters; dark brown (7.5YR 3/4) unrubbed hemic sedge material; 60 per cent unrubbed fibers; 25 per cent rubbed fibers; von Post scale 5.

Oa1 - - 31 to 63 centimeters; black (10YR 2/1) unrubbed sapric muck; 20 per cent unrubbed fibers; 7 per cent rubbed fibers; von Post scale 7; coniferous needle layer 40 to 43 centimeters.

Oa2 - - 63 to 103 centimeters; dark brown (7.5YR 3/3) unrubbed sapric muck; 30 per cent unrubbed fibers; 12 per cent rubbed fibers; von Post scale 6.

Oe - - 103 to 121 centimeters; brown (7.5YR 4/4) unrubbed hemic sedge material; 90 per cent unrubbed fibers; 40 per cent rubbed fibers; von Post scale 4. 
Canaan Valley National Wildlife Refuge, Davis, Tucker County, West Virginia

7 August 2014

Profile 3.04, Terric Haplosaprist

Location: 39.14426, -79.35707

Compiled by M. Schaney and R. Fedders

Oi - - 0 to 10 centimeters; dark brown (7.5YR 3/4) unrubbed fibric peat; 95 per cent unrubbed fibers; 80 per cent rubbed fibers; von Post scale 2.

Oa1 - 10 to 18 centimeters; black (10YR 2/1) unrubbed sapric muck; loose consistence; 3 per cent unrubbed fibers; 1 per cent rubbed fibers; von Post scale 8.

Oa2 - 18 to 50 centimeters; black (10YR 2/1) unrubbed sapric muck; 25 per cent unrubbed fibers; 7 per cent rubbed fibers; von Post scale 7; some wood fragments.

C1 - 50 to 59 centimeters; dark brown (10YR 3/3) silty clay; no organic matter.

C2 - 59 to 70 centimeters; brown (10YR 4/3) clay; no organic matter. 
Canaan Valley National Wildlife Refuge, Davis, Tucker County, West Virginia

7 August 2014

Profile 3.05, Terric Haplosaprist

Location: $39.14359,-79.35509$

Compiled by M. Schaney and R. Fedders

Oi - - 0 to 8 centimeters; dark brown (7.5YR 3/4) unrubbed fibric sphagnum peat; 80 per cent unrubbed fibers; 55 per cent rubbed fibers; von Post scale 3.

Oa1 - - 8 to 27 centimeters; black (10YR 2/1) unrubbed sapric silty muck; weak granular structure; charcoal fragments; 15 per cent unrubbed fibers; 5 per cent rubbed fibers; von Post scale 7.

Oa2 - - 27 to 52 centimeters; black (10YR 2/1) unrubbed sapric muck; 30 per cent unrubbed fibers; 10 per cent rubbed fibers; von Post scale 6; some wood fragments.

Oa3 - - 52 to 70 centimeters; dark brown (7.5YR 3/4) unrubbed sapric sedge muck; 30 per cent unrubbed fibers; 15 per cent rubbed fibers; von Post scale 6.

Cg - - 70 to 80 centimeters; grayish brown (2.5Y 5/2) clay; 3 per cent organic matter. 
Canaan Valley National Wildlife Refuge, Davis, Tucker County, West Virginia

8 August 2014

Profile 3.06, Sapric Haplohemist

Location: 39.14320, -79.35838

Compiled by M. Schaney, C. Schaney, and S. Marsh

Oi - - 0 to 8 centimeters; dark brown (7.5YR 3/4) unrubbed fibric sphagnum peat; 100 per cent unrubbed fibers; 85 per cent rubbed fibers; von Post scale 3.

Oa - - 8 to 14 centimeters; black (7.5YR 2.5/1) unrubbed sapric muck; light foamy texture; 20 per cent unrubbed fibers; 10 per cent rubbed fibers; von Post scale 8.

Oe - - 14 to 38 centimeters; dark brown (7.5YR 3/4) unrubbed hemic sedge mucky peat with horsetails; 60 per cent unrubbed fibers; 30 per cent rubbed fibers; von Post scale 4.

Oa1 - - 38 to 53 centimeters; black (10YR 2/1) unrubbed sapric muck; wet loose consistence; slimy texture; 30 per cent unrubbed fibers; 15 per cent rubbed fibers; von Post scale 7; coniferous needles layer at 43 centimeters.

Oa2 - - 53 to 68 centimeters; black (10YR 2/1) unrubbed sapric material; light foamy texture; 10 per cent unrubbed fibers; 5 per cent rubbed fibers; von Post scale 8.

Oe - - 68 to 164 centimeters; brown (10YR 4/3) unrubbed hemic mucky peat; 60 per cent unrubbed fibers; 35 per cent rubbed fibers; von Post scale 5 grading down to 3 .

Cg - 164 to 180 centimeters; dark grayish brown (2.5Y 4/2) clay.

Remarks: This profiled is $30 \mathrm{~cm}$ hemic and $30 \mathrm{~cm}$ sapric in subsurface tier, for classification, neighboring core profiles were consulted. 
Canaan Valley National Wildlife Refuge, Davis, Tucker County, West Virginia

8 August 2014

Profile 3.07, Typic Haplohemist

Location: 39.14300, -79.35992

Compiled by M. Schaney, C. Schaney, and S. Marsh

Oi - - 0 to 6 centimeters; dark brown (7.5YR 3/4) unrubbed fibric sphagnum peat; 100 per cent unrubbed fibers; 85 per cent rubbed fibers; von Post scale 2.

Oa - - 6 to 15 centimeters; black (7.5YR 2.5/1) unrubbed sapric muck; light foamy texture; 20 per cent unrubbed fibers; 10 per cent rubbed fibers; von Post scale 8; clear smooth boundary.

Oe1 - - 15 to 48 centimeters; dark brown (10YR 3/3) unrubbed hemic muck; 30 per cent unrubbed fibers; 20 per cent rubbed fibers; von Post scale 5; wet loose consistence.

Oe2 - - 48 to 156 centimeters; dark yellowish brown (10YR 3/4) unrubbed hemic sedge mucky peat; 60 per cent unrubbed fibers; 30 per cent rubbed fibers; von Post scale 4; abrupt boundary.

Cg - 156 to 180 centimeters; dark grayish brown (2.5Y 4/2) clay. 
Canaan Valley National Wildlife Refuge, Davis, Tucker County, West Virginia

8 August 2014

Profile 3.08, Typic Haplohemist

Location: 39.14200, -79.36200

Compiled by M. Schaney, C. Schaney, and S. Marsh

Oi - - 0 to 10 centimeters; dark brown (7.5YR 3/4) unrubbed fibric sphagnum peat; 100 per cent unrubbed fibers; 85 per cent rubbed fibers; von Post scale 2.

Oa - 10 to 15 centimeters; black (7.5YR 2.5/1) unrubbed sapric muck; light foamy texture; 20 per cent unrubbed fibers; 10 per cent rubbed fibers; von Post scale 8; clear smooth boundary.

Oe1 - 15 to 47 centimeters; dark brown (10YR 3/3) unrubbed hemic muck; 30 per cent unrubbed fibers; 20 per cent rubbed fibers; von Post scale 5; wet loose consistence; thick charcoal at 24 centimeters; gradual boundary.

Oe2 - - 47 to 160 centimeters; dark yellowish brown (10YR 3/4) unrubbed hemic sedge mucky peat; 60 per cent unrubbed fibers; 30 per cent rubbed fibers; von Post scale 4; inter-fingered boundary.

Cg - 160 to 170 centimeters; dark grayish brown (2.5Y 4/2) clay. 
Canaan Valley National Wildlife Refuge, Davis, Tucker County, West Virginia

8 August 2014

Profile 3.09, Typic Haplohemist

Location: 39.14168, -79.36290

Compiled by M. Schaney, C. Schaney, and S. Marsh

Oi - - 0 to 10 centimeters; dark brown (7.5YR 3/4) unrubbed fibric sphagnum peat; 100 per cent unrubbed fibers; 85 per cent rubbed fibers; von Post scale 2.

Oa - - 10 to 23 centimeters; black (10YR 2/1) unrubbed sapric muck; 20 per cent unrubbed fibers; 10 per cent rubbed fibers; von Post scale 7; light and foamy texture.

Oe1 - 23 to 60 centimeters; dark brown (10YR 3/3) unrubbed hemic sedge muck; 40 per cent unrubbed fibers; 20 per cent rubbed fibers; von Post scale 6.

Oe2 - - 60 to 130 centimeters; dark yellowish brown (10YR 3/4) unrubbed hemic mucky peat; 60 per cent unrubbed fibers; 40 per cent rubbed fibers; von Post scale 5; wet sawdust.

Cg - 130 to 165 centimeters; dark grayish brown (2.5Y 4/2) clay. 
Canaan Valley National Wildlife Refuge, Davis, Tucker County, West Virginia

8 August 2014

Profile 3.10, Terric Haplohemist

Location: 39.14210, -79.36400

Compiled by M. Schaney, C. Schaney, and S. Marsh

Oi - - 0 to 10 centimeters; dark brown (7.5YR 3/4) unrubbed fibric sphagnum peat; 100 per cent unrubbed fibers; 85 per cent rubbed fibers; von Post scale 2.

Oa - - 10 to 34 centimeters; black (10YR 2/1) unrubbed sapric muck; 10 per cent unrubbed fibers; 3 per cent rubbed fibers; von Post scale 6; coniferous needle layer at 16 centimeters.

Oe - - 34 to 70 centimeters; dark yellowish brown (10YR 3/4) unrubbed hemic sedge material; 40 per cent unrubbed fibers; 20 per cent rubbed fibers; von Post scale 4/5.

Oe- - 70 to 82 centimeters; dark brown (10YR 3/3) unrubbed hemic mucky peat clay; 60 per cent unrubbed fibers; 40 per cent rubbed fibers; von Post scale 4; gradual transition.

Cg - - 82 to 100 centimeters; dark grayish brown (2.5Y 4/2) clay; streaks of greenish gray $5 / 10 \mathrm{GY}$. 
Canaan Valley National Wildlife Refuge, Davis, Tucker County, West Virginia

8 August 2014

Profile 3.11, Typic Haplohemist

Location: $39.14280,-79.36210$

Compiled by M. Schaney, C. Schaney, and S. Marsh

Oi - - 0 to 10 centimeters; dark brown (7.5YR 3/4) unrubbed fibric sphagnum peat; 100 per cent unrubbed fibers; 85 per cent rubbed fibers; von Post scale 2.

Oa - - 10 to 49 centimeters; black (10YR 2/1) unrubbed sapric muck; 10 per cent unrubbed fibers; 3 per cent rubbed fibers; von Post scale 6/7; light and foamy texture.

Oe1 - - 49 to 102 centimeters; dark brown (10YR 3/3) unrubbed hemic sedge mucky peat; 40 per cent unrubbed fibers; 20 per cent rubbed fibers; von Post scale 5.

Oe2 - - 102 to 160 centimeters; dark yellowish brown (10YR 3/4) unrubbed hemic mucky peat; 60 per cent unrubbed fibers; 40 per cent rubbed fibers; von Post scale 4; wet sawdust. 
Canaan Valley National Wildlife Refuge, Davis, Tucker County, West Virginia

9 August 2014

Profile 3.12, Terric Haplosaprist

Location: $39.14480,-79.36000$

Compiled by M. Schaney, C. Schaney, and T. Talbott

Oi - - 0 to 8 centimeters; dark brown (7.5YR 3/4) unrubbed fibric sphagnum peat; 100 per cent unrubbed fibers; 85 per cent rubbed fibers; von Post scale 2.

Oa - - 8 to 20 centimeters; black (10YR 2/1) unrubbed sapric muck; 10 per cent unrubbed fibers; 3 per cent rubbed fibers; von Post scale 8.

Oe - - 20 to 48 centimeters; brown (10YR 4/3) unrubbed hemic sedge material; 60 per cent unrubbed fibers; 20 per cent rubbed fibers; von Post scale 4.

Oa1 - - 48 to 66 centimeters; black (10YR 2/1) unrubbed sapric muck material; common cranberry roots; 30 per cent unrubbed fibers; 10 per cent rubbed fibers; von Post scale 6.

Oa2 - - 66 to 123 centimeters; black (10YR 2/1) unrubbed sapric muck material; 10 per cent unrubbed fibers; 5 per cent rubbed fibers; von Post scale 7/8; diffuse boundary.

C - - 123 to 135 centimeters; very dark grayish brown (10YR 3/2) clay. 
Canaan Valley National Wildlife Refuge, Davis, Tucker County, West Virginia

9 August 2014

Profile 3.13, Sapric Haplohemist

Location: $39.14566,-79.35989$, softer, wetter core with no woody vegetation on surface.

Compiled by M. Schaney, C. Schaney, and T. Talbott

Oi - - 0 to 10 centimeters; dark brown (7.5YR 3/4) unrubbed fibric peat; 100 per cent unrubbed fibers; 85 per cent rubbed fibers; von Post scale 2.

Oa - - 10 to 20 centimeters; black (10YR 2/1) unrubbed sapric muck; 10 per cent unrubbed fibers; 2 per cent rubbed fibers; von Post scale 7.

$11-13 \mathrm{~cm}$ Radiocarbon age $1925 \pm 30$ (median cal yr BP 1873)

Oe - - 20 to 62 centimeters; dark brown (7.5YR 3/4) unrubbed hemic sedge mucky peat with horsetails; 50 per cent unrubbed fibers; 20 per cent rubbed fibers; von Post scale 4/5.

$27-29 \mathrm{~cm}$ Radiocarbon age $3155 \pm 30$ (median cal yr BP 3382)

$50-52 \mathrm{~cm}$ Radiocarbon age $3590 \pm 30$ (median cal yr BP 3894)

Oa - - 62 to 76 centimeters; black (7.5YR 2.5/1) unrubbed sapric muck; common cranberry roots; 30 per cent unrubbed fibers; 15 per cent rubbed fibers; von Post scale 6.

$64-66 \mathrm{~cm}$ Radiocarbon age $5180 \pm 30$ (median cal yr BP 5936)

$75-77 \mathrm{~cm}$ Radiocarbon age $10095 \pm 40$ (median cal yr BP 11687)

Oe - - 76 to 92 centimeters; very dark brown (7.5YR 2.5/2) unrubbed hemic mucky peat; 50 per cent unrubbed fibers; 20 per cent rubbed fibers; von Post scale 5; wet particle board.

$83-85 \mathrm{~cm}$ Radiocarbon age $11085 \pm 35$ (median cal yr BP 12960)

Oa - - 92 to 170 centimeters; very dark brown (7.5YR 2.5/2) unrubbed sapric muck, 25 per cent unrubbed fibers; 12 per cent rubbed fibers, von Post scale 6; no identifiable plant fibers resemble wet sawdust.

94-96cm Radiocarbon age $11680 \pm 30$ (median cal yr BP 13510)

$120-122 \mathrm{~cm}$ Radiocarbon age $13815 \pm 40$ (median cal yr BP 16715)

$165-167 \mathrm{~cm}$ Radiocarbon age $15375 \pm 35$ (median cal yr BP 18653)

Cg - - at 170 centimeters; dark grayish brown (2.5Y 4/2) clay.

Remarks: deferred to lab data on repeat core at same location for classification. 
Canaan Valley National Wildlife Refuge, Davis, Tucker County, West Virginia 28 July 2015

Profile 3.13, Sapric Haplohemist - REAPEAT- Full Core Sample

Location: $39.14566,-79.35989$

Compiled by M. Schaney, S. Morris, and J. Baker

Oi - - 0 to 7 centimeters; dark brown (7.5YR 3/4) unrubbed fibric peat; 100 per cent unrubbed fibers; 85 per cent rubbed fibers; von Post scale 2.

Fiber Content 80\%: Fibric

Pyrophosphate Color N 8/1: Fibric

Mineral Content $=\mathbf{1 . 7 6 \%}$

Organic Content $=\mathbf{9 8 . 2 4 \%}$

Oa - - 7 to 20 centimeters; black (10YR 2/1) unrubbed sapric muck; 10 per cent unrubbed fibers; 2 per cent rubbed fibers; von Post scale 7.

Bulk Density $(10-15 \mathrm{~cm}) 0.15 \mathrm{~g} / \mathrm{cm}^{3}$ : $\underline{\text { Hemic }}$

Fiber Content 8\%: Sapric

Pyrophosphate Color 10YR 4/4, 10YR 5/6: $\underline{\text { Sapric }}$

Lab pH 2.87

Mineral Content $=\mathbf{1 . 8 1 \%}$

Organic Content $=\mathbf{9 8 . 1 9 \%}$

Oe - - 20 to 80 centimeters; dark yellowish brown (10YR 4/4) unrubbed hemic sedge mucky peat; 50 per cent unrubbed fibers; 30 per cent rubbed fibers; von Post scale 4.

Bulk Density $(35-40 \mathrm{~cm}) 0.12$ and $(60-65 \mathrm{~cm}) 0.09 \mathrm{~g} / \mathrm{cm}^{3}$ : $\underline{\text { Hemic }}$

Fiber Content 32\%: Hemic

Pyrophosphate Color 10YR 8/3, 10YR 6/3: Fibric/Sapric

Lab pH 3.16

Mineral Content $=\mathbf{2 . 8 5 \%}$

Organic Content $=\mathbf{9 7 . 1 5 \%}$

Oa - - 80 to 90 centimeters; reddish black (2.5YR 2.5/1) unrubbed sapric muck; 15 per cent unrubbed fibers; 10 per cent rubbed fibers; von Post scale 6.

Bulk Density $(80-85 \mathrm{~cm}) 0.17 \mathrm{~g} / \mathrm{cm}^{3}$ : $\underline{\text { Hemic }}$

Fiber Content 16\%: Sapric

Pyrophosphate Color 10YR 3/3, 10YR 5/4: $\underline{\text { Sapric }}$

Lab pH 3.21

Mineral Content $=\mathbf{2 3 . 5 4 \%}$

Organic Content $=\mathbf{7 6 . 4 6} \%$

Oe - - 90 to 170 centimeters; very dark brown (7.5YR 2.5/2) unrubbed hemic mucky peat, 25 per cent unrubbed fibers; 15 per cent rubbed fibers, von Post scale 5.

Bulk Density $(105-110 \mathrm{~cm}) 0.19$ and $(135-140) 0.34 \mathrm{~g} / \mathrm{cm}^{3}$ : $\underline{\text { Hemic/Sapric }}$

Fiber Content 24\%: Hemic

Pyrophosphate Color 10YR 5/4, 10YR 5/6: $\underline{\text { Sapric }}$ 


\section{Lab pH 3.69}

Mineral Content $=\mathbf{3 6 . 0 7 \%}$

Organic Content $=\mathbf{6 3 . 9 3} \%$

Could not get to mineral soil. 
Canaan Valley National Wildlife Refuge, Davis, Tucker County, West Virginia 16 May 2017

Profile 3.13, Sapric Haplohemist - REPEAT for pollen analysis

Location: 39.14566, -79.35989,

Compiled by M. Schaney, Z. Taylor, M. Albritton, and C. Anderson of Berry College

Oi - - 0 to 19 centimeters; dark reddish brown (5YR 3/4) unrubbed fibric peat; 100 per cent unrubbed fibers; 98 per cent rubbed fibers; von Post scale 2.

Oa - - 19 to 31 centimeters; black (10YR 2/1) unrubbed sapric muck; 5 per cent unrubbed fibers; 2 per cent rubbed fibers; von Post scale 7.

Oe - - 31 to 82 centimeters; very dark brown (7.5YR 2.5/2) unrubbed hemic mucky peat; 60 per cent unrubbed fibers; 40 per cent rubbed fibers; von Post scale 4.

Oa - - 82 to 96 centimeters; black (10YR 2/1) unrubbed sapric muck; 20 per cent unrubbed fibers; 10 per cent rubbed fibers; von Post scale 7.

Oe1 - - 96 to 120 centimeters; dark brown (7.5YR 3/3) unrubbed hemic mucky peat; 20 per cent unrubbed fibers; 20 per cent rubbed fibers; von Post scale 4/5.

Oe2 - - 120 to 193 centimeters; dark brown (7.5YR 3/2) unrubbed hemic mucky peat, 50 per cent unrubbed fibers; 30 per cent rubbed fibers, von Post scale 3/4; section $150 \mathrm{~cm}$ to $173 \mathrm{~cm}$ missing for description but collected for sampling.

Oe3 - - 193 to 221 centimeters; brown (10YR 4/3) unrubbed hemic mucky peat, 40 per cent unrubbed fibers; 50 per cent rubbed fibers, von Post scale 5.

Cg - - 221 to226 centimeters; dark gray (10YR 4/1) silty clay. 
Canaan Valley National Wildlife Refuge, Davis, Tucker County, West Virginia

9 August 2014

Profile 3.14, Sapric Haplohemist - Full Core Sample

Location: $39.14321,-79.36038$

Compiled by M. Schaney, S. Marsh, and N. Funk

Oi - - 0 to 10 centimeters; dark brown (7.5YR 3/4) unrubbed fibric peat; 100 per cent unrubbed fibers; 85 per cent rubbed fibers; von Post scale 2.

Oa - - 10 to 60 centimeters; black (10YR 2/1) unrubbed sapric muck; 10 per cent unrubbed fibers; 2 per cent rubbed fibers; von Post scale 7.

Oe - - 60 to 155 centimeters; dark brown (7.5YR 3/4) unrubbed hemic sedge material; 50 per cent unrubbed fibers; 20 per cent rubbed fibers; von Post scale 5.

121-123m Radiocarbon age $13870 \pm 40$ (median cal yr BP 16802)

Cg - - 155 to 167 centimeters; dark grayish brown (2.5Y 4/2) clay.

Remarks: This profiled is $30 \mathrm{~cm}$ hemic and $30 \mathrm{~cm}$ sapric in subsurface tier, for classification, neighboring core profiles were consulted. 
Canaan Valley National Wildlife Refuge, Davis, Tucker County, West Virginia

9 August 2014

Profile 3.15, Hemic Haplosaprist

Location: $39.14486,-79.35818$

Compiled by M. Schaney, C. Schaney, T. Talbott, S. Marsh, and N. Funk

Oi - - 0 to 10 centimeters; dark brown (7.5YR 3/4) unrubbed fibric peat; 100 per cent unrubbed fibers; 85 per cent rubbed fibers; von Post scale 2.

Oa - - 10 to 19 centimeters; black (10YR 2/1) unrubbed sapric muck; 10 per cent unrubbed fibers; 2 per cent rubbed fibers; von Post scale 7.

Oe - 19 to 49 centimeters; dark brown (7.5YR 3/4) unrubbed hemic sedge mucky peat; 50 per cent unrubbed fibers; 20 per cent rubbed fibers; von Post scale 5.

Oa - - 49 to 87 centimeters; black (10YR 2/1) unrubbed sapric muck; 20 per cent unrubbed fibers; 10 per cent rubbed fibers; von Post scale 7; coniferous needles at 43 centimeters and from 67 to 73 centimeters.

Oe - - 87 to 136 centimeters; dark brown (7.5YR 3/4) unrubbed hemic sedge mucky peat; 50 per cent unrubbed fibers; 20 per cent rubbed fibers; von Post scale 5, wet particle board.

Cg - - 136 to 150 centimeters; dark grayish brown (2.5Y 4/2) clay. 
Canaan Valley National Wildlife Refuge, Davis, Tucker County, West Virginia

2 June 2015

Profile 3.16, Sapric Haplohemist

Location: $39.14295,-79.35909$

Compiled by M. Schaney, J. Bernosky, H. Jewell, and E. Davis

Oi - - 0 to 10 centimeters; dark brown (7.5YR 3/4) unrubbed fibric peat; 100 per cent unrubbed fibers; 95 per cent rubbed fibers; von Post scale 2.

Oa - - 10 to 23 centimeters; black (10YR 2/1) unrubbed sapric muck; 10 per cent unrubbed fibers; 1 per cent rubbed fibers; von Post scale 7.

Oi - - 23 to 53 centimeters; dark brown (10YR 3/3) unrubbed fibric sedge peat; 55 per cent unrubbed fibers; 30 per cent rubbed fibers; von Post scale 5.

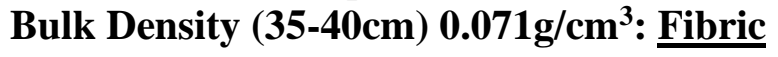

Oe - - 53 to 130 centimeters; very dark brown (7.5YR 2.5/3) unrubbed hemic sedge mucky peat; 50 per cent unrubbed fibers; 15 per cent rubbed fibers; von Post scale 5.

Bulk Density $(80-85 \mathrm{~cm})$ 0.104g/cm ${ }^{3}$ : Hemic

Bulk Density $(115-120 \mathrm{~cm})$ 0.156g/cm ${ }^{3}$ : $\underline{\text { Hemic }}$

Oa - - 130 to 180 centimeters; very dark brown (7.5YR 2.5/3) unrubbed sapric muck; 80 per cent unrubbed fibers; 25 per cent rubbed fibers; von Post scale 6, wet particle board.

Bulk Density $(155-160 \mathrm{~cm}) \mathbf{0 . 2 0 g} / \mathrm{cm}^{3}$ : Sapric

Remarks: deferred to lab data for classification and horizon designation. 
Canaan Valley National Wildlife Refuge, Davis, Tucker County, West Virginia

2 June 2015

Profile 3.17, Terric Haplohemist

Location: $39.14220,-79.36052$

Compiled by M. Schaney, J. Bernosky, H. Jewell, and E. Davis

Oi - - 0 to 8 centimeters; dark brown (7.5YR 3/4) unrubbed fibric peat; 100 per cent unrubbed fibers; 95 per cent rubbed fibers; von Post scale 2.

Oa - - 8 to 20 centimeters; black (10YR 2/1) unrubbed sapric muck; 10 per cent unrubbed fibers; 1 per cent rubbed fibers; von Post scale 7.

Oe - - 20 to 70 centimeters; dark brown (10YR 3/3) unrubbed hemic sedge mucky peat; 60 per cent unrubbed fibers; 35 per cent rubbed fibers; von Post scale $4 / 5$.

Bulk Density $(30-35 \mathrm{~cm})$ 0.172 $\mathrm{g} / \mathrm{cm}^{3}$ : $\underline{\text { Hemic }}$

Oa1 - - 70 to 95 centimeters; very dark grayish brown (10YR 3/2) unrubbed sapric muck; 30 per cent unrubbed fibers; 15 per cent rubbed fibers; von Post scale 6.

Bulk Density $(75-80 \mathrm{~cm})$ 0.190g/cm³

Oa2 - - 95 to 106 centimeters; very dark brown (7.5YR 2.5/3) unrubbed sapric muck with clay; 30 per cent unrubbed fibers; 15 per cent rubbed fibers; von Post scale 6.

Bulk Density $(95-100 \mathrm{~cm}) 0.379 \mathrm{~g} / \mathrm{cm}^{3}$ : Sapric

C - - 106 clay 
Canaan Valley National Wildlife Refuge, Davis, Tucker County, West Virginia

28 July 2015

Profile 3.18, Terric Haplosaprist

Location: $39.14376,-79.35604$

Compiled by M. Schaney, S. Morris, and J. Baker.

Oi - - 0 to 28 centimeters; dark brown (7.5YR 3/4) unrubbed fibric peat; 100 per cent unrubbed fibers; 95 per cent rubbed fibers; von Post scale 2.

Oa1 - - 28 to 73 centimeters; black (10YR 2/1) unrubbed sapric muck; 10 per cent unrubbed fibers; 1 per cent rubbed fibers.

Bulk Density $(58-63 \mathrm{~cm}) 0.16 \mathrm{~g} / \mathrm{cm}^{3} \underline{\text { Hemic }}$

Fiber Content $4 \%$ Sapric

Pyrophosphate Color 10YR 4/3, 10YR 4/4: Sapric

Lab pH 2.8

$82 \%$ Organic content

Oa2 - - 73 to 90 centimeters; dark brown (10YR 3/3) unrubbed sapric muck; 60 per cent

unrubbed fibers; 35 per cent rubbed fibers; 20 per cent silt.

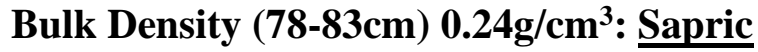

Fiber Content 0\%: $\underline{\text { Sapric }}$

Pyrophosphate Color 10YR 3/2, 10YR 3/4: Sapric

Lab pH 2.92

$86 \%$ Organic content

Oa3 - - 90 to 117 centimeters; very dark grayish brown (10YR 3/2) unrubbed sapric muck; 30 per cent unrubbed fibers; 15 per cent rubbed fibers; gradual boundary.

Bulk Density $(98-103 \mathrm{~cm}) 0.30 \mathrm{~g} / \mathrm{cm}^{3}$ : Sapric

Fiber Content 2\%: $\underline{\text { Sapric }}$

Pyrophosphate Color 10YR 5/6, 10YR 5/6: $\underline{\text { Sapric }}$

Lab pH 3.31

$62 \%$ Organic content

Cg - - 117 to 122 centimeters; dark gray (2.5Y 4/1) sandy loam.

Lab pH 3.91 
Canaan Valley National Wildlife Refuge, Davis, Tucker County, West Virginia

1 October 2014

Profile 4.01, Typic Haplohemist, Full Core Sample Collected and Frozen

Location: 39.13157, -79.35680

Compiled by M. Schaney, J. Teets, S. Bell, and T. Dilliplane

Oi - - 0 to 19 centimeters; red (2.5YR 4/6) unrubbed fibric sphagnum material; 100 per cent unrubbed fibers; 98 per cent rubbed fibers; von Post scale 2.

Oa - 19 to 25 centimeters; black (10YR 2/1) unrubbed sapric material; 5 per cent unrubbed fibers; 5 per cent rubbed fibers; von Post scale 8; abrupt smooth boundary.

Oe1 - - 25 to 118 centimeters; very dark brown (7.5YR 2.5/2) unrubbed hemic sedge and horsetail material; 75 per cent unrubbed fibers; 25 per cent rubbed fibers; von Post scale 4 .

Oe2 - - 118 to 182 centimeters; very dark brown (7.5YR 2.5/2) unrubbed hemic sedge and horsetail material; 60 per cent unrubbed fibers; 18 per cent rubbed fibers; von Post scale 5; less identifiable sedge and horsetail fibers.

C1 - - 182 to 220 centimeters; very dark brown (7.5YR 2.5/2) mucky silt loam.

C2 - 220 to 230 centimeters; dark brown (7.5YR 3/2) silty clay loam. 
Canaan Valley National Wildlife Refuge, Davis, Tucker County, West Virginia

1 October 2014

Profile 4.02, Typic Haplohemist, Full Core Sample

Location: 39.12964, -79.35961, no Sphagnum, different moss on surface.

Compiled by M. Schaney, J. Teets, S. Bell, and T. Dilliplane

Oi - - 0 to 7 centimeters; dark reddish brown (5YR 3/2) unrubbed fibric moss material; 100 per cent unrubbed fibers; 80 per cent rubbed fibers; von Post scale 2.

Oa - 7 to 18 centimeters; black (10YR 2/1) unrubbed sapric material; 5 per cent unrubbed fibers; 5 per cent rubbed fibers; von Post scale 8; abrupt smooth boundary.

$7-9 \mathrm{~cm}$ Radiocarbon age $420 \pm 35$ (median cal yr BP 486)

$17-20 \mathrm{~cm}$ Radiocarbon age $2130 \pm 30$ (median cal yr BP 2111) - measured off lab sample core

Oe1 - 18 to 110 centimeters; very dark brown (7.5YR 2.5/2) unrubbed hemic sedge and horsetail material; 75 per cent unrubbed fibers; 25 per cent rubbed fibers; von Post scale 4 .

$76-79 \mathrm{~cm}$ Radiocarbon age $3240 \pm 30$ (median cal yr BP 3460)

Oe2 - - 110 to 150 centimeters; very dark brown (7.5YR 2.5/2) unrubbed hemic sedge and horsetail material; 60 per cent unrubbed fibers; 18 per cent rubbed fibers; von Post scale 5; small wood fibers from 150 to 160 centimeters.

$117-120 \mathrm{~cm}$ Radiocarbon age $4095 \pm 35$ (median cal yr BP 4607)

Cg - 150 to 186 centimeters; gray (7.5YR 5/1) clay. 
Canaan Valley National Wildlife Refuge, Davis, Tucker County, West Virginia

25 March 2015

Profile 4.03, Entisol

Location: $39.13503,-79.36017$

Compiled by M. Schaney, Z. Haidar, P. Hopkins, and G. Stewart

Oa - - 0 to 15 centimeters; black (10YR 2/1) unrubbed sapric muck; 20 per cent unrubbed fibers; 5 per cent rubbed fibers; von Post scale 8; clear boundary.

C - 15 to 30 centimeters; brown (10YR 5/3) clay. 
Canaan Valley National Wildlife Refuge, Davis, Tucker County, West Virginia

25 March 2015

Profile 4.04, Sapric Haplohemist

Location: $39.13363,-79.36000$

Compiled by M. Schaney, Z. Haidar, P. Hopkins, and G. Stewart

Oe1 - - 0 to 40 centimeters; dark yellowish brown (10YR 3/4) unrubbed hemic sedge and horsetail mucky peat; 50 per cent unrubbed fibers; 20 per cent rubbed fibers; von Post scale 4.

Oe2 - - 40 to 90 centimeters; dark yellowish brown (10YR 3/4) unrubbed hemic mucky peat; 60 per cent unrubbed fibers; 20 per cent rubbed fibers; von Post scale 4.

Oa1 - - 90 to 123 centimeters; black (10YR 2/1) unrubbed sapric muck; 5 per cent unrubbed fibers; 1 per cent rubbed fibers; von Post scale 8.

Oa2 - - 123 to 140 centimeters; dark brown (7.5YR 3/3) unrubbed sapric muck with silt clay; 15 per cent unrubbed fibers; 5 per cent rubbed fibers.

C - - 140 to 150 centimeters; brown (10YR 4/3) silt loam. 
Canaan Valley National Wildlife Refuge, Davis, Tucker County, West Virginia

25 March 2015

Profile 4.05, Sapric Haplohemist

Location: $39.13071,-79.36214$

Compiled by M. Schaney, Z. Haidar, P. Hopkins, and G. Stewart

Oi - - 0 to 6 centimeters; dark yellowish brown (10YR 3/4) unrubbed fibric peat; 100 per cent unrubbed fibers; 90 per cent rubbed fibers; von Post scale 2.

Oe - - 6 to 110 centimeters; dark yellowish brown (10YR 3/4) unrubbed hemic mucky peat; 60 per cent unrubbed fibers; 20 per cent rubbed fibers; von Post scale 4.

Oa1 - - 110 to 127 centimeters; black (10YR 2/1) unrubbed sapric muck; 15 per cent unrubbed fibers; 5 per cent rubbed fibers; von Post scale 8 .

Oa2 - - 127 to 217 centimeters; dark brown (7.5YR 3/3) unrubbed sapric muck; 30 per cent unrubbed fibers; 5 per cent rubbed fibers; von Post scale 6.

Cg - - 217 to 226 centimeters; dark grayish brown (2.5Y 4/2) clay loam. 
Canaan Valley National Wildlife Refuge, Davis, Tucker County, West Virginia

25 March 2015

Profile 4.06, Terric Haplosaprist

Location: 39.12697, -79.36158

Compiled by M. Schaney, Z. Haidar, P. Hopkins, and G. Stewart

Oi - - 0 to 4 centimeters; dark yellowish brown (10YR 3/4) unrubbed fibric peat; 90 per cent unrubbed fibers; 80 per cent rubbed fibers; von Post scale 2.

Oe - - 4 to 8 centimeters; dark yellowish brown (10YR 3/4) unrubbed hemic mucky peat; 60 per cent unrubbed fibers; 20 per cent rubbed fibers; von Post scale 4.

Oa1 - - 8 to 13 centimeters; black (10YR 2/1) unrubbed sapric muck; 10 per cent unrubbed fibers; 2 per cent rubbed fibers; Von Post scale 8.

Oa2 - - 13 to 42 centimeters; dark brown (7.5YR 3/4) unrubbed sapric muck; 40 per cent unrubbed fibers; 10 per cent rubbed fibers; von Post scale 6.

Cg - - 42 to 50 centimeters; dark grayish brown (2.5Y 4/2) clay loam. 
Canaan Valley National Wildlife Refuge, Davis, Tucker County, West Virginia

26 March 2015

Profile 4.07, Sapric Haplohemist

Location: 39.12982, -79.35217

Compiled by M. Schaney, L. Fox, P. Hopkins, and T. Messenger

Oi - - 0 to 5 centimeters; dark yellowish brown (10YR 3/4) unrubbed fibric peat; 90 per cent unrubbed fibers; 80 per cent rubbed fibers; von Post scale 2.

Oa - 5 to 10 centimeters; black (10YR 2/1) unrubbed sapric muck; 10 per cent unrubbed fibers; 5 per cent rubbed fibers; von Post scale 8.

Oe - 10 to 110 centimeters; dark yellowish brown (10YR 3/4) unrubbed hemic mucky peat; 40 per cent unrubbed fibers; 20 per cent rubbed fibers; von Post scale 5.

Oa - - 110 to 136 centimeters; dark brown (7.5YR 3/3) unrubbed sapric muck; 20 per cent unrubbed fibers; 5 per cent rubbed fibers; von Post scale 4; gradual boundary.

Cg - 136 to 150 centimeters; grayish brown (2.5Y 5/2) silty clay. 
Canaan Valley National Wildlife Refuge, Davis, Tucker County, West Virginia

26 March 2015

Profile 4.08, Sapric Haplohemist

Location: $39.13188,-79.35464$

Compiled by M. Schaney, L. Fox, P. Hopkins, and T. Messenger

Oi - - 0 to 12 centimeters; dark yellowish brown (10YR 3/4) unrubbed fibric peat; 90 per cent unrubbed fibers; 80 per cent rubbed fibers; von Post scale 2.

Oa - - 12 to 20 centimeters; black (10YR 2/1) unrubbed sapric muck; 10 per cent unrubbed fibers; 5 per cent rubbed fibers; von Post scale 8 .

Oe - - 20 to 90 centimeters; dark yellowish brown (10YR 3/4) unrubbed hemic sedge mucky peat; 60 per cent unrubbed fibers; 20 per cent rubbed fibers; von Post scale 5.

Oa - - 90 to 143 centimeters; black (10YR 2/1) unrubbed sapric muck; 20 per cent unrubbed fibers; 10 per cent rubbed fibers; von Post scale 7.

Oe - - 143 to 160 centimeters; dark brown (7.5YR 3/4) unrubbed hemic mucky peat; 70 per cent unrubbed fibers; 30 per cent rubbed fibers; von Post scale 5; gradual boundary.

Cg - - 160 to 185 centimeters; grayish brown (2.5Y 5/2) silt loam. 
Canaan Valley National Wildlife Refuge, Davis, Tucker County, West Virginia 26 March 2015

Profile 4.09, Typic Haplohemist

Location: $39.13077,-79.3595$, grass and thin moss layer as surface vegetation

Compiled by M. Schaney, L. Fox, P. Hopkins, and T. Messenger

Oa1 - - 0 to 8 centimeters; black (10YR 2/1) unrubbed sapric muck; 10 per cent unrubbed fibers; 5 per cent rubbed fibers; von Post scale 8.

Oa2 - - 8 to 26 centimeters; dark reddish brown (5YR 2.5/2) unrubbed hemic sphagnum mucky peat; 60 per cent unrubbed fibers; 25 per cent rubbed fibers; von Post scale 7.

Oe - - 26 to 140 centimeters; dark brown (7.5YR 3/4) unrubbed hemic sedge mucky peat; 60 per cent unrubbed fibers; 30 per cent rubbed fibers; von Post scale 4.

C - - 140 to 150 centimeters; olive brown (2.5Y 4/3) silty clay.

Collected next 150 to $200 \mathrm{~cm}$. 
Canaan Valley National Wildlife Refuge, Davis, Tucker County, West Virginia

26 March 2015

Profile 4.10, Sapric Haplohemist

Location: 39.12900, -79.36200

Compiled by M. Schaney, L. Fox, P. Hopkins, and T. Messenger

Oi - - 0 to 5 centimeters; dark yellowish brown (10YR 3/4) unrubbed fibric peat; 90 per cent unrubbed fibers; 80 per cent rubbed fibers; von Post scale 2.

Oa - 5 to 10 centimeters; black (10YR 2/1) unrubbed sapric muck; 10 per cent unrubbed fibers; 5 per cent rubbed fibers; von Post scale 8.

Oe - - 10 to 90 centimeters; dark yellowish brown (10YR 3/4) unrubbed hemic sedge mucky peat; 60 per cent unrubbed fibers; 35 per cent rubbed fibers; von Post scale 5.

Oa1 - - 90 to 110 centimeters; black (10YR 2/1) unrubbed sapric muck; 30 per cent unrubbed fibers; 10 per cent rubbed fibers; von Post scale 7.

Oa2 - - 110 to 170 centimeters; dark brown (7.5YR 3/4) unrubbed sapric muck; 20 per cent unrubbed fibers; 5 per cent rubbed fibers; von Post scale 6 . Texture of wet particle board; could not get deeper. 
Canaan Valley National Wildlife Refuge, Davis, Tucker County, West Virginia

26 March 2015

Profile 4.11, Sapric Haplohemist

Location: $39.12875,-79.36046$

Compiled by M. Schaney, L. Fox, P. Hopkins, and T. Messenger

Oi - - 0 to 8 centimeters; dark yellowish brown (10YR 3/4) unrubbed fibric peat; 90 per cent unrubbed fibers; 80 per cent rubbed fibers; von Post scale 2.

Oa - 8 to 18 centimeters; black (10YR 2/1) unrubbed sapric muck; 10 per cent unrubbed fibers; 5 per cent rubbed fibers; von Post scale 8.

Oe - - 18 to 120 centimeters; dark brown (10YR 3/3) unrubbed hemic sedge mucky peat; 60 per cent unrubbed fibers; 20 per cent rubbed fibers; von Post scale 5.

Oa1 - 120 to 138 centimeters; black (10YR 2/1) unrubbed sapric muck; 5 per cent unrubbed fibers; 2 per cent rubbed fibers; von Post scale 8 .

Oa2 - - 138 to 160 centimeters; very dark brown (10YR 2/2) unrubbed sapric muck; 20 per cent unrubbed fibers; 5 per cent rubbed fibers; von Post scale 6.

C - 160 to 170 centimeters; gray (2.5Y 5/1) loam. 
Canaan Valley National Wildlife Refuge, Davis, Tucker County, West Virginia 26 March 2015

Profile 4.12, Terric Haplosaprist

Location: $39.13500,-79.35200$

Compiled by M. Schaney, L. Fox, P. Hopkins, and T. Messenger

Oi - - 0 to 23 centimeters; yellowish brown (10YR 5/6) unrubbed fibric peat; 90 per cent unrubbed fibers; 60 per cent rubbed fibers; von Post scale 2.

Oa - - 23 to 38 centimeters; black (10YR 2/1) unrubbed sapric muck; 10 per cent unrubbed fibers; 5 per cent rubbed fibers; von Post scale 8 .

Oe - - 38 to 53 centimeters; dark reddish brown (2.5YR 3/4) unrubbed hemic sedge mucky peat with woody material; 80 per cent unrubbed fibers; 25 per cent rubbed fibers; von Post scale 6.

Oa - - 53 to 113 centimeters; black (10YR 2/1) unrubbed sapric muck; 15 per cent unrubbed fibers; 7 per cent rubbed fibers; von Post scale 8; gradual boundary.

C - - 113 to 143 centimeters; gray (5YR 5/1) clay loam, with a rounded quartz pebble. 
Canaan Valley National Wildlife Refuge, Davis, Tucker County, West Virginia

26 March 2015

Profile 4.13, Terric Haplosaprist

Location: $39.13156,-79.35192$

Compiled by M. Schaney, L. Fox, P. Hopkins, and T. Messenger

Oi - - 0 to 8 centimeters; yellowish brown (10YR 5/6) unrubbed fibric peat; 90 per cent unrubbed fibers; 60 per cent rubbed fibers; von Post scale 2.

Oa1 - - 8 to 24 centimeters; black (10YR 2/1) unrubbed sapric muck; 10 per cent unrubbed fibers; 5 per cent rubbed fibers; von Post scale 8; field $\mathrm{pH} 4.7$.

Oe - - 24 to 44 centimeters; dark brown (10YR 3/3) unrubbed hemic sedge mucky peat; 50 per cent unrubbed fibers; 20 per cent rubbed fibers; von Post scale 5; field pH 4.7.

Oa - - 44 to 66 centimeters; very dark grayish brown (10YR 3/2) unrubbed sapric muck; 10 per cent unrubbed fibers; 5 per cent rubbed fibers; von Post scale 6; gradual boundary; field pH 4.6.

Oa - - 66 to 92 centimeters; dark brown (10YR 3/3) unrubbed sapric muck; 20 per cent unrubbed fibers; 5 per cent rubbed fibers; von Post scale 7; gradual boundary; field pH 4.7.

C - - 92 to 98 centimeters; dark grayish brown (10YR 4/2) clay loam. 
Canaan Valley National Wildlife Refuge, Davis, Tucker County, West Virginia

20 May 2015

Profile 4.14, Sapric Haplohemist

Location: 39.13200, -79.36000, no Sphagnum moss on surface.

Compiled by M. Schaney, A. Hoss, A. Moore, and W. Tuttle

Oa - - 0 to 8 centimeters; black (10YR 2/1) unrubbed sapric muck; 10 per cent unrubbed fibers; 2 per cent rubbed fibers; von Post scale 7.

Oe1 - - 8 to 90 centimeters; very dark brown (7.5YR 2.5/2) unrubbed hemic sedge mucky peat; 40 per cent unrubbed fibers; 20 per cent rubbed fibers; few fine cranberry roots; von Post scale 5.

Oe2 - - 90 to 130 centimeters; dark brown (7.5YR 3/3) unrubbed hemic mucky peat; 60 per cent unrubbed fibers; 25 per cent rubbed fibers; von Post scale 4.

Oa1 - - 130 to 157 centimeters; black (7.5YR 2.5/1) unrubbed sapric muck; 20 per cent unrubbed fibers; 10 per cent rubbed fibers; wood fragments; von Post scale 6; gradual boundary.

Oa2 - - 157 to 213 centimeters; dark brown (10YR 3/3) unrubbed sapric muck with 10 per cent silty clay; 20 per cent unrubbed fibers; 5 per cent rubbed fibers; von Post scale 6; gradual boundary.

Cg1 - - 213 to 225 centimeters; dark grayish brown (2.5Y 4/2) silty loam; faint depositional lenses; abrupt boundary.

Cg2 - - 225 to 237 centimeters; dark greenish gray (5G 4/1) silty clay. 
Canaan Valley National Wildlife Refuge, Davis, Tucker County, West Virginia

20 May 2015

Profile 4.15, Terric Haplosaprist

Location: 39.13167, -79.36342, near vegetation change at western end, no Sphagnum moss on surface.

Compiled by M. Schaney, A. Hoss, A. Moore, and W. Tuttle

Oa - - 0 to 15 centimeters; black (10YR 2/1) unrubbed sapric muck; 5 per cent unrubbed fibers; 2 per cent rubbed fibers; von Post scale 8.

Oe - - 15 to 54 centimeters; very dark grayish brown (10YR 3/2) unrubbed hemic sedge mucky peat; 40 per cent unrubbed fibers; 20 per cent rubbed fibers; von Post scale 4; gradual boundary.

Oa1 - - 54 to 80 centimeters; very dark brown (10YR 2/2) unrubbed sapric muck; 15 per cent unrubbed fibers; 2 per cent rubbed fibers; wood fragments; von Post scale 7.

Oa2 - - 80 to 103 centimeters; dark brown (10YR 3/3) unrubbed sapric muck with 15 per cent silty clay; 5 per cent unrubbed fibers; 1 per cent rubbed fibers; von Post scale 8.

C - - 103 to 116 centimeters; dark yellowish brown (10YR 3/4) silty loam. 
Canaan Valley National Wildlife Refuge, Davis, Tucker County, West Virginia

3 June 2015

Profile 4.16, Typic Haplohemist

Location: $39.13022,-79.35808$

Compiled by M. Schaney, J. Bernosky, H. Jewell, and E. Davis

Oi - - 0 to 13 centimeters; very dusky red (2.5YR 2.5/2) unrubbed fibric peat; 100 per cent unrubbed fibers; 95 per cent rubbed fibers; von Post scale 2.

Oa - - 13 to 30 centimeters; reddish black (2.5YR 2.5/1) unrubbed sapric muck; 15 per cent unrubbed fibers; 5 per cent rubbed fibers; von Post scale 7;

Oe - - 30 to 135 centimeters; dark reddish brown (5YR 2.5/2) unrubbed hemic sedge material; 60 per cent unrubbed fibers; 30 per cent rubbed fibers; von Post scale 5.

Bulk Density $(75-80 \mathrm{~cm}) 0.0937 \mathrm{~g} / \mathrm{cm}^{3}$ : Fibric

Bulk Density (120-125cm) 0.1099 g/cm

Oa - - 135 to 142 centimeters; black (7.5YR 2.5/1) unrubbed sapric muck; 35 per cent unrubbed fibers; 2 per cent rubbed fibers; von Post scale 7.

C - - 142 to 152 centimeters; gray (5YR 5/1) silty clay. 
Canaan Valley National Wildlife Refuge, Davis, Tucker County, West Virginia

3 June 2015

Profile 4.17, Terric Haplosaprist

Location: 39.12885, -79.35269, in hollow (large depression), no surface Sphagnum.

Compiled by M. Schaney, J. Bernosky, H. Jewell, and E. Davis

Oa - - 0 to 28 centimeters; black (5YR 2.5/1) unrubbed sapric muck; 5 per cent unrubbed fibers; 1 per cent rubbed fibers; von Post scale 7; field $\mathrm{pH} 5$.

Bulk Density $(5-10 \mathrm{~cm}) 0.19 \mathrm{~g} / \mathrm{cm}^{3}$ : $\underline{\text { Hemic }}$

Oe - - 28 to 47 centimeters; black (5YR 2.5/1) unrubbed sapric muck; 2 per cent unrubbed fibers; 0 per cent rubbed fibers; von Post scale 7; field $\mathrm{pH} 5$.

Bulk Density $(35-40 \mathrm{~cm}) \mathbf{0 . 1 5} \mathrm{g} / \mathrm{cm}^{3}$ : $\underline{\text { Hemic }}$

Lab and field data differ, go with lab data

Oa1 - - 47 to 60 centimeters; black (10YR 2/1) unrubbed sapric muck; 3 per cent unrubbed fibers; 0 per cent rubbed fibers; von Post scale 7; field pH 5.

Bulk Density $(55-60 \mathrm{~cm}) 0.33 \mathrm{~g} / \mathrm{cm}^{3}$ : $\underline{\text { Sapric }}$

Oa2 - - 60 to 67 centimeters; black (10YR 2/1) unrubbed sapric muck with 20 per cent silty clay; 1 per cent unrubbed fibers; 0 per cent rubbed fibers; von Post scale 7; field pH 5.

C1 - - 67 to 71 centimeters; weak red (2.5YR 5/3) silty clay loam; field pH 6.

C2 - - 71 to 76 centimeters; weak red (2.5YR 5/2) silty clay; field pH 6. 
Canaan Valley National Wildlife Refuge, Davis, Tucker County, West Virginia

25 June 2015

Profile 4.18, Terric Haplosaprist

Location: $39.12755,-79.35993$

Compiled by M. Schaney, J. Bernosky, and M. Eltahir

Oi - - 0 to 30 centimeters; dark brown (7.5YR 3/3) unrubbed fibric peat; 100 per cent unrubbed fibers; 95 per cent rubbed fibers; von Post scale 2.

Oa - - 30 to 47 centimeters; black (10YR 2/1) unrubbed sapric muck; 5 per cent unrubbed fibers; 2 per cent rubbed fibers; von Post scale 7.

C1 - - 47 to 58 centimeters; very dark brown (10YR 2/2) silty clay.

C2 - - 58 to 65 centimeters; very dark grayish brown (10YR 3/2) clay loam.

C3 - - 65 to 80 centimeters; dark grayish brown (10YR 4/2) sandy clay loam. 
Canaan Valley National Wildlife Refuge, Davis, Tucker County, West Virginia

25 June 2015

Profile 4.19, Sapric Haplohemist

Location: $39.13032,-79.36110$

Compiled by M. Schaney, J. Bernosky, and M. Eltahir

Oi - - 0 to 8 centimeters;

Oa - - 20 to 28 centimeters; black (10YR 2/1) unrubbed sapric muck; 15 per cent unrubbed fibers; 5 per cent rubbed fibers; von Post scale 7.

Oe1 - - 28 to 140 centimeters; very dark grayish brown (10YR 3/2) unrubbed hemic peaty muck; 40 per cent unrubbed fibers; 20 per cent rubbed fibers; von Post scale 5.

Bulk Density $(30-35 \mathrm{~cm}, 80-85 \mathrm{~cm}$, and $125-130 \mathrm{~cm}) 0.09 \mathrm{~g} / \mathrm{cm}^{3}$ : Fibric/Hemic

Fiber Content 28\%: Hemic

Pyrophosphate Color 10YR 8/2, 2.5YR 8/2: Fibric

Lab pH: 3.18

99.61\% organic matter

$30-32 \mathrm{~cm}$ Radiocarbon age $2490 \pm 30$ (median cal yr BP 2584)

$60-62 \mathrm{~cm}$ Radiocarbon age $2925 \pm 30$ (median cal yr BP 3072)

$80-82 \mathrm{~cm}$ Radiocarbon age $3235 \pm 30$ (median cal yr BP 3453)

Oe2 - - 140 to 163 centimeters; dark brown (10YR 3/3) unrubbed hemic peaty muck; 40 per cent unrubbed fibers; 15 per cent rubbed fibers; von Post scale 5.

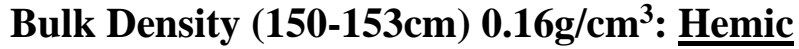

Fiber Content 24\%: $\underline{\text { Hemic }}$

Pyrophosphate Color 10YR 7/3, 10YR 4/2: Hemic/Sapric

Lab pH: 3.74

$97.42 \%$ organic matter

120-122cm Radiocarbon age $3775 \pm 35$ (median cal yr BP 4146) - measured from lab

sample core

Oa1 - - 163 to 178 centimeters; black (10YR 2/1) unrubbed sapric muck; 5 per cent unrubbed fibers; 2 per cent rubbed fibers; von Post scale 7.

Fiber Content 12\%: $\underline{\text { Sapric }}$

Pyrophosphate Color 10YR 4/3, 10YR 4/4: $\underline{\text { Sapric }}$

Lab pH: 3.78

81.61\% organic matter

Oa2 - - 178 to 205 centimeters; very dark brown (7.5YR 2.5/3) unrubbed sapric muck; 5 per cent unrubbed fibers; 2 per cent rubbed fibers; von Post scale 7.

Bulk Density $(195-200 \mathrm{~cm}) 0.17 \mathrm{~g} / \mathrm{cm}^{3}$ : $\underline{\text { Hemic }}$

Fiber Content 8\%: $\underline{\text { Sapric }}$

Pyrophosphate Color 10YR 5/3, 10YR 4/6: Sapric

Lab pH: 4.21

98.47\% organic matter 
$165-167 \mathrm{~cm}$ Radiocarbon age $11235 \pm 35$ (median cal yr BP 13097) - measured from lab sample core

Oe - - 205 to 232 centimeters; dark reddish brown (5YR 2.5/2) unrubbed hemic mucky peat; 10 per cent unrubbed fibers; 5 per cent rubbed fibers; von Post scale 6.

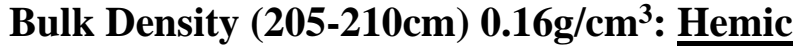

Fiber Content 36\%: $\underline{\text { Hemic }}$

Pyrophosphate Color 10YR 6/4, 10YR 6/4: Sapric

Lab pH: 4.69

$70.81 \%$ organic matter

211-213cm Radiocarbon age $12850 \pm 40$ (median cal yr BP 15315)

C - - 232 to 235 centimeters; dark grayish brown (10YR 4/2) silty clay loam.

Lab pH: 5.13

$\mathbf{2 2 . 6 1 \%}$ organic matter 
Canaan Valley National Wildlife Refuge, Davis, Tucker County, West Virginia

25 June 2015

Profile 4.20, Sapric Haplohemist

Location: $39.13340,-79.35962$

Compiled by M. Schaney, J. Bernosky, and M. Eltahir

Oa - - 0 to 12 centimeters; black (10YR 2/1) unrubbed sapric muck; 5 per cent unrubbed fibers;

2 per cent rubbed fibers; von Post scale 8.

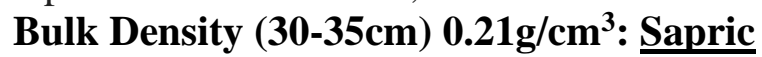

Fiber Content 20\%: $\underline{\text { Hemic }}$

Pyrophosphate Color 10YR 4/4, 10YR 4/6: $\underline{\text { Sapric }}$

Lab pH: 2.74

$\mathbf{9 0 . 9 8 \%}$ organic matter

Oe - - 12 to 108 centimeters; very dark brown (7.5YR 2.5/3) unrubbed hemic peaty muck; 40 per cent unrubbed fibers; 15 per cent rubbed fibers; von Post scale 5.

Bulk Density $(30-35 \mathrm{~cm}) 0.12 \mathrm{~g} / \mathrm{cm}^{3}$ and $(80-85 \mathrm{~cm}) 0.09 \mathrm{~g} / \mathrm{cm}^{3}: \underline{\text { Hemic/Fibric }}$

Fiber Content 28\%: $\underline{\text { Hemic }}$

Pyrophosphate Color 10YR 8/4, 2.5YR 8/2: Hemic/Fibric

Lab pH: 2.96

$97.89 \%$ organic matter

Oa1 - - 108 to 132 centimeters; black (10YR 2/1) unrubbed sapric muck; 3 per cent unrubbed fibers; 1 per cent rubbed fibers; von Post scale 8 .

Bulk Density $(115-120 \mathrm{~cm}) \mathrm{0.16g} / \mathrm{cm}^{3}$ : $\underline{\text { Hemic }}$

Fiber Content 0\%: Sapric

Pyrophosphate Color 10YR 4/3, 7.5YR 4/3: Sapric

Lab pH: 3.07

$\mathbf{7 7 . 6 8 \%}$ organic matter

Oa2 - - 132 to 157 centimeters; dark yellowish brown (10YR 4/4) unrubbed sapric muck; 2 per cent unrubbed fibers; 1 per cent rubbed fibers; von Post scale 8/9.

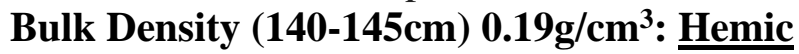

Fiber Content 2\%: $\underline{\text { Sapric }}$

Pyrophosphate Color 10YR 3/4, 10YR 4/6: $\underline{\text { Sapric }}$

Lab pH: 3.43

$75.33 \%$ organic matter

C - - 157 to 170 centimeters; dark grayish brown (10YR 4/2) silty clay.

Lab pH: 3.62

$12.41 \%$ organic matter

Canaan Valley National Wildlife Refuge, Davis, Tucker County, West Virginia

25 June 2015

Profile 4.21, Entisol

Location: 39.13402, -79.35921

Compiled by M. Schaney, J. Bernosky, and M. Eltahir 
Oi - - 0 to 6 centimeters; very dusky red (2.5YR 2.5/2) unrubbed fibric peat; 100 per cent unrubbed fibers; 95 per cent rubbed fibers; von Post scale 2.

Oa1 - - 6 to 13 centimeters; black (10YR 2/1) unrubbed sapric muck; 2 per cent unrubbed fibers; 1 per cent rubbed fibers; von Post scale 7.

Oa2 - - 13 to 20 centimeters; black (10YR 2/1) unrubbed sapric muck; 30 per cent unrubbed fibers; 10 per cent rubbed fibers; von Post scale 6.

C1 - - 20 to 30 centimeters; brown (10YR 5/3) silty clay.

C2 - - 30 to 50 centimeters; grayish brown (10YR 5/2) silty clay. 
Canaan Valley National Wildlife Refuge, Davis, Tucker County, West Virginia

16 June 2014

Profile 5.01, Hemic Haplosaprist

Location: $39.11890,-79.38280$

Compiled by M. Schaney, S. Bell, K. Yost, S. Marsh, E. Byers, J. Teets, J. Burkhart, and R. Polakovsky

Oi - - 0 to 16 centimeters; 60 per cent brown (7.5YR 5/4) and 40 per cent dark red (2.5 YR 3/6) unrubbed fibric sphagnum peat; 100 per cent unrubbed fibers; 98 per cent rubbed fibers; von Post scale 2; field $\mathrm{pH} 4.5$.

Oa - - 16 to 30 centimeters; black (5YR 2.5/1) sapric muck; 15 per cent unrubbed fibers; 7 per cent rubbed fibers; von Post scale 7; field $\mathrm{pH} 4.5$.

Oi - - 30 to 49 centimeters; reddish black (2.5YR 2.5/1) fibric peat; 80 per cent unrubbed fibers; 50 per cent rubbed fibers; von Post scale 3; field $\mathrm{pH} 4.5$.

Oe - - 49 to 63 centimeters; dark reddish brown (5YR 3/3) hemic mucky peat; 60 per cent unrubbed fibers; 35 per cent rubbed fibers; von Post scale 5; field $\mathrm{pH} 4.8$.

Oa - - 63 to 120 centimeters; black $(2.5 / \mathrm{N})$ sapric muck; 10 per cent unrubbed fibers; 2 per cent rubbed fibers; wood fragments at 70 centimeters; von Post scale 6; gradual boundary; field $\mathrm{pH}$ 4.8 .

Oe1 - - 120 to 160 centimeters; very dark brown (7.5YR 2.5/2) hemic mucky peat; 60 per cent unrubbed fibers; 20 per cent rubbed fibers; von Post scale 4; field $\mathrm{pH} 4.5$.

Oe2 - - 160 to 220 centimeters; vary dark brown (7.5YR 2.5/2) hemic mucky peat; 60 per cent unrubbed fibers; 25 per cent rubbed fibers; von Post scale 5; gradual boundary; field pH 4.5.

Cg - - 220 to 249 centimeters; dark gray (2.5Y 4/1) massive very fine sandy loam; field pH 5.3. 
Canaan Valley National Wildlife Refuge, Davis, Tucker County, West Virginia

17 June 2014

Profile 5.02, Hemic Haplofibrist

Location: $39.11880,-79.38330$

Compiled by M. Schaney and R. Polakovsky

Oi - - 0 to 10 centimeters; reddish brown (5YR 4/4) fibric sphagnum peat; 100 per cent unrubbed fibers; 95 per cent rubbed fibers; von Post scale 2.

Oa - - 10 to 18 centimeters; black (10YR 2/1) sapric muck; 20 per cent unrubbed fibers; 15 per cent rubbed fibers; von Post scale 7.

Oe - - 18 to 56 centimeters; dark brown (7.5YR 3/4) hemic sedge mucky peat; 80 per cent unrubbed fibers; 30 per cent rubbed fibers; von Post scale 4.

Oi - - 56 to 102 centimeters; reddish black (2.5YR 2.5/1) fibric sedge peat; 80 per cent unrubbed fibers; 55 per cent rubbed fibers; von Post scale 3.

Oa - - 102 to 160 centimeters; black (10YR 2/1) sapric muck; 10 per cent unrubbed fibers; 2 per cent rubbed fibers; coniferous needles; von Post scale 7.

Oe - - 160 to 175 centimeters; dark brown (7.5YR 3/3) hemic sedge mucky peat; 60 per cent unrubbed fibers; 30 per cent rubbed fibers; von Post scale 4; field $\mathrm{pH} 4.5$. 
Canaan Valley National Wildlife Refuge, Davis, Tucker County, West Virginia

17 June 2014

Profile 5.03, Hemic Haplofibrist

Location: $39.11860,-79.38400$

Compiled by M. Schaney and R. Polakovsky

Oi - - 0 to 7 centimeters; reddish brown (5YR 4/4) fibric sphagnum peat; 100 per cent unrubbed fibers; 95 per cent rubbed fibers; von Post scale 2.

Oa - - 7 to 12 centimeters; black (10YR 2/1) sapric muck; 20 per cent unrubbed fibers; 15 per cent rubbed fibers; von Post scale 7.

Oe - - 12 to 36 centimeters; strong brown (7.5YR 4/6) hemic sedge mucky peat with cranberry roots; 80 per cent unrubbed fibers; 35 per cent rubbed fibers; von Post scale 4.

Oi - - 36 to 68 centimeters; dark reddish brown (5YR 2.5/2) fibric sedge peat; 80 per cent unrubbed fibers; 50 per cent rubbed fibers; von Post scale 3.

Oa1 - - 68 to 115 centimeters; dark brown (7.5YR 3/2) sapric sedge muck; 60 per cent unrubbed fibers; 15 per cent rubbed fibers; von Post scale 6.

Oa2 - - 115 to 197 centimeters; black (10YR 2/1) sapric muck with wood fragments, leaf fragments, and coniferous needles at 145 centimeters; 10 per cent unrubbed fibers; 5 per cent rubbed fibers; von Post scale 8.

Oa3 - - 197 to 232 centimeters; dark brown (7.5YR 3/2) sapric muck with grass inflorescence; 40 per cent unrubbed fibers; 10 per cent rubbed fibers; von Post scale 6.

Oa4 - - 232 to 237 centimeters; dark brown (7.5YR 3/2) sapric mucky clay. 
Canaan Valley National Wildlife Refuge, Davis, Tucker County, West Virginia

17 June 2014

Profile 5.04, Fibric Haplohemist

Location: $39.11840,-79.38470$

Compiled by M. Schaney and R. Polakovsky

Oi - - 0 to 15 centimeters; reddish brown (5YR 4/4) fibric sphagnum peat; 100 per cent unrubbed fibers; 95 per cent rubbed fibers; von Post scale 2.

Oa - - 15 to 28 centimeters; black (10YR 2/1) sapric muck; 20 per cent unrubbed fibers; 15 per cent rubbed fibers; von Post scale 7.

Oe - - 28 to 76 centimeters; very dark brown (7.5YR 2.5/2) hemic sedge mucky peat; 70 per cent unrubbed fibers; 25 per cent rubbed fibers; von Post scale 4; gradual boundary.

Oi - - 76 to 104 centimeters; dark reddish brown (5YR 2.5/2) fibric sedge peat; 90 per cent unrubbed fibers; 60 per cent rubbed fibers; von Post scale 3.

Oa - - 104 to 170 centimeters; black (10YR 2/1) sapric sedge muck with 20 per cent clay; at 115 to 130 centimeters wood fragments; at 142 centimeters coniferous needles; 20 per cent unrubbed fibers; 3 per cent rubbed fibers; von Post scale 7.

Oe - - 170 to 227 centimeters; dark brown (7.5YR 3/3) hemic sedge mucky peat; 60 per cent unrubbed fibers; 25 per cent rubbed fibers; von Post scale 4; gradual boundary.

C - - 227 to 230 centimeters; dark brown (7.5YR 3/3) silty clay. 
Canaan Valley National Wildlife Refuge, Davis, Tucker County, West Virginia

14 July 2014

Profile 5.06, Terric Haplohemist

Location: $39.11758,-79.39110$

Compiled by M. Schaney, S. Marsh, and R. Polakovsky

Oi - - 0 to 18 centimeters; dark brown (7.5YR 3/2) fibric peat; 65 per cent unrubbed fibers; 40 per cent rubbed fibers.

Oa - - 18 to 30 centimeters; black (10YR 2/1) sapric muck; 10 per cent unrubbed fibers; 5 per cent rubbed fibers.

Oe - - 30 to 38 centimeters; very dark brown (7.5YR 2.5/2) hemic sedge mucky peat; 30 per cent unrubbed fibers; 20 per cent rubbed fibers.

Oa - - 38 to 61 centimeters; black (10YR 2/1) sapric muck with some clay; 10 per cent unrubbed fibers; 5 per cent rubbed fibers. Black round seeds.

Oe - - 61 to 103 centimeters; dark brown (7.5YR 3/2) hemic sedge mucky peat; 25 per cent unrubbed fibers; 20 per cent rubbed fibers.

C - - 103 to 115 centimeters; brown (7.5YR 4/2) silty clay. 
Canaan Valley National Wildlife Refuge, Davis, Tucker County, West Virginia

14 July 2014

Profile 5.07, Hemic Haplosaprist

Location: 39.11600, -79.38840

Compiled by M. Schaney, S. Marsh, and R. Polakovsky

Oi - - 0 to 17 centimeters; reddish brown (5YR 4/4) fibric peat; 100 per cent unrubbed fibers; 95 per cent rubbed fibers; von Post scale 2; clear smooth boundary.

Oa - 17 to 97 centimeters; black (10YR 2/1) sapric muck; 10 per cent unrubbed fibers; 5 per cent rubbed fibers; concretion at 83 centimeters.

Oe1 - - 97 to 145 centimeters; very dark brown (7.5YR 2.5/2) hemic sedge mucky peat; 30 per cent unrubbed fibers; 20 per cent rubbed fibers.

Oe2 - - 145 to 231 centimeters dark brown (7.5YR 3/3) hemic mucky peat; 65 per cent unrubbed fibers; 30 per cent rubbed fibers; gradual boundary.

C - - 231 to 237 centimeters; brown (7.5YR 4/2) silty clay; lens of fine sand with 30 per cent fibers. 
Canaan Valley National Wildlife Refuge, Davis, Tucker County, West Virginia

14 July 2014

Profile 5.08, Typic Haplosaprist

Location: $39.11800,-79.38900$

Compiled by M. Schaney, S. Marsh, and R. Polakovsky

Oi - - 0 to 25 centimeters; reddish brown (5YR 4/4) fibric sphagnum peat; 100 per cent unrubbed fibers; 98 per cent rubbed fibers; von Post scale 2; clear smooth boundary. Water table at 25 centimeters.

Fiber Content 56\%: Fibric

Pyrophosphate Color 10YR 7/4, 10YR 7/3: $\underline{\text { Hemic }}$

Lab pH: 3.36

Organic matter: $99.32 \%$

Oa1 - - 25 to 65 centimeters; black (10YR 2/1) sapric muck; 5 per cent unrubbed fibers; 2 per cent rubbed fibers; von Post scale 8; clear smooth boundary. Coniferous needles at $65 \mathrm{~cm}$, sampled.

Fiber Content 12\%: $\underline{\text { Sapric }}$

Pyrophosphate Color 10YR 4/3, 7.5YR 4/3: Sapric

Lab pH: 3.15

Organic matter: $99.20 \%$

Oa2 - - 65 to 120 centimeters; black (10YR 2/1) sapric muck; 5 per cent unrubbed fibers; 2 per cent rubbed fibers; von Post scale 7; clear smooth boundary; cranberry roots; 100 to $107 \mathrm{~cm}$ and at 130 centimeters layer of coniferous needles.

Fiber Content $(65-107 \mathrm{~cm}) 2 \%$ : Sapric

Pyrophosphate Color 10YR 3/3, 10YR 5/4: Sapric

Lab pH: 2.98

Organic matter: $98.54 \%$

Oe1 - - 120 to 208 centimeters; dark brown (7.5YR 3/2) hemic sedge mucky peat, 50 per cent unrubbed fibers; 20 per cent rubbed fibers, von Post scale 4; clear smooth boundary. Insect remains at 180 centimeters collected.

Fiber Content (120-160) 20\%: Hemic

Pyrophosphate Color 10YR 8/2, 10YR 7/2: Fibric

Lab pH: 3.28

Organic matter: $93.68 \%$

Oe2 - - 208 to 280 centimeters; dark brown (7.5YR 3/4) hemic mucky peat, 90 per cent unrubbed fibers; 50 per cent rubbed fibers, von Post scale 5, consistency of wet particle board, coniferous needles at 225; clear smooth boundary.

Fiber Content (120-160) 20\%: $\underline{\text { Hemic }}$

Pyrophosphate Color 10YR 8/2, 10YR 6/4: Fibric, Sapric

Lab pH: 3.47

Organic matter: $97.66 \%$ 
C - 280 to 290 centimeters; dark grayish brown (2.5YR 4/2) fine sandy loam. 
Canaan Valley National Wildlife Refuge, Davis, Tucker County, West Virginia

16 July 2014

Profile 5.09, Terric Haplosaprist

Location: $39.12016,-79.38890$, mostly woody shrubs

Compiled by M. Schaney, S. Marsh, and T. Harris

Oi - - 0 to 5 centimeters; reddish brown (5YR 4/4) fibric sphagnum peat; 100 per cent unrubbed fibers; 95 per cent rubbed fibers; von Post scale 2; clear smooth boundary.

Oa - - 5 to 14 centimeters; black (7.5YR 2.5/1) sapric muck; 15 per cent unrubbed fibers; 10 per cent rubbed fibers; von Post scale 8.

Oi - - 14 to 58 centimeters; dark brown (7.5YR 3/3) fibric peat; 80 per cent unrubbed fibers; 50 per cent rubbed fibers; von Post scale 3.

Oa1 - - 58 to 89 centimeters; black (10YR 2/1) sapric muck; 10 per cent unrubbed fibers; 7 per cent rubbed fibers; 7 . 82-89 centimeters spruce/hemlock needles, sample collected.

Oa2 - - 89 to 110 centimeters; dark brown (7.5YR 3/3) sapric muck; 30 per cent unrubbed fibers; 10 per cent rubbed fibers; von Post scale 6; diffuse boundary.

C - - 110 to 119 centimeters; dark brown (7.5YR 3/3) silty clay. Sample collected. 
Canaan Valley National Wildlife Refuge, Davis, Tucker County, West Virginia

16 July 2014

Profile 5.10, Terric Haplosaprist

Location: $39.12135,-79.38362$

Compiled by M. Schaney, S. Marsh, and T. Harris

Oi - - 0 to 23 centimeters; reddish yellow (7.5YR 6/6) fibric sphagnum peat; 100 per cent unrubbed fibers; 90 per cent rubbed fibers; von Post scale 2.

Oe - - 23 to 28 centimeters; dark brown (7.5YR 3/3) hemic sedge mucky peat; 60 per cent unrubbed fibers; 30 per cent rubbed fibers; von Post scale 5.

Oa1 - - 28 to 66 centimeters; black (7.5YR 2.5/1) sapric muck; 5 per cent unrubbed fibers; 2 per cent rubbed fibers; von Post scale 8. Black round seeds, some clay content, only root fibers visible.

Oa2 - - 66 to 90 centimeters; very dark brown (7.5YR 2.5/2) sapric muck; 30 per cent unrubbed fibers; 5 per cent rubbed fibers; von Post scale 6. Very few needles present, and wood fragments.

C - - 90 to 97 centimeters; brown (7.5YR 4/2) silty clay. 
Canaan Valley National Wildlife Refuge, Davis, Tucker County, West Virginia 16 July 2014

Profile 5.11, Terric Haplosaprist

Location: $39.12205,-79.38067$, drier location, less woody vegetation

Compiled by M. Schaney, S. Marsh, and T. Harris

Oi1 - - 0 to 10 centimeters; reddish yellow (7.5YR 6/6) fibric sphagnum peat; 100 per cent unrubbed fibers; 90 per cent rubbed fibers; von Post scale 2.

Oi2 - - 10 to 14 centimeters; very dark brown (7.5YR 2.5/2) fibric sphagnum peat; 80 per cent unrubbed fibers; 50 per cent rubbed fibers; von Post scale 3.

Oa - 14 to 38 centimeters; black (7.5YR 2.5/1) sapric muck; 20 per cent unrubbed fibers; 10 per cent rubbed fibers; von Post scale 7. Some clay content, only root fibers visible.

Oe - - 38 to 100 centimeters; dark brown (7.5YR 3/3) hemic sedge mucky peat; 30 per cent unrubbed fibers; 20 per cent rubbed fibers; von Post scale 5.

C - - 100 to 105 centimeters; brown (7.5YR 4/2) silty clay with very fine sand. 
Canaan Valley National Wildlife Refuge, Davis, Tucker County, West Virginia 16 July 2014

Profile 5.12, Sapric Haplohemist, Full Core Sample

Location: $39.12408,-79.37626$, softer, wetter core with no woody vegetation on surface.

Compiled by M. Schaney, S. Marsh, and T. Harris

Oi - - 0 to 5 centimeters; reddish yellow (7.5YR 6/6) fibric sphagnum peat; 100 per cent unrubbed fibers; 90 per cent rubbed fibers; von Post scale 2; clear smooth boundary.

Oa - - 5 to 10 centimeters; black (7.5YR 2.5/1) sapric muck; 10 per cent unrubbed fibers; 5 per cent rubbed fibers; von Post scale 7; clear smooth boundary.

Oe1 - - 10 to 36 centimeters; dark brown (7.5YR 3/3) hemic sedge mucky peat; many cranberry roots; 80 per cent unrubbed fibers; 25 per cent rubbed fibers; von Post scale 4.

$16-20 \mathrm{~cm}$ Radiocarbon age $2080 \pm 30$ (median cal yr BP 2050)

Oe2 - - 36 to 62 centimeters; black (7.5YR 2.5/1) hemic mucky peat; many cranberry roots; 50 per cent unrubbed fibers; 40 per cent rubbed fibers; von Post scale 4 . 44 to $55 \mathrm{~cm}$ mostly spruce with some hemlock (Z. Fowler, 2015) needles.

$51-53 \mathrm{~cm}$ Radiocarbon age $2495 \pm 30$ (median cal yr BP 2585)

Oa1 - - 62 to 84 centimeters; black (7.5YR 2.5/1) sapric muck; 50 per cent unrubbed fibers; 20 per cent rubbed fibers; von Post scale 7; wet, soft horizon; spruce needles throughout horizon, only identifiable vegetation that remained after rubbing.

$82-85 \mathrm{~cm}$ Radiocarbon age $2725 \pm 30$ (median cal yr BP 2817)

Oa2 - - 84 to 118 centimeters; black (7.5YR 2.5/1) sapric muck, 5 per cent unrubbed fibers; 2 per cent rubbed fibers, von Post scale 8; thicker, denser, not as moist horizon.

$114-116 \mathrm{~cm}$ Radiocarbon age $9010 \pm 30$ (median cal yr BP 10204)

Oe - - 118 to 202 centimeters; dark brown (7.5YR 3/3) hemic sedge mucky peat, 30 per cent unrubbed fibers; 20 per cent rubbed fibers, von Post scale 4; wood chunk; rubbed to very small fibers.

197-199cm Radiocarbon age $13105 \pm 35$ (median cal yr BP 15733)

Cg - - 202 to 210 centimeters; gray (7.5YR 5/1) fine to medium sand. 
Canaan Valley National Wildlife Refuge, Davis, Tucker County, West Virginia

16 July 2014

Profile 5.13, Sapric Haplohemist

Location: $39.11973,-79.38237$

Compiled by M. Schaney, S. Marsh, and T. Harris

Oi - - 0 to 22 centimeters; reddish yellow (7.5YR 6/6) fibric sphagnum peat; 100 per cent unrubbed fibers; 90 per cent rubbed fibers; von Post scale 2; clear smooth boundary.

Oa - - 22 to 42 centimeters; black (10YR 2/1) sapric muck; 10 per cent unrubbed fibers; 5 per cent rubbed fibers; von Post scale 7; clear smooth boundary.

Oe - - 42 to 74 centimeters; very dark brown (7.5YR 2.5/2) hemic mucky peat; 40 per cent unrubbed fibers; 30 per cent rubbed fibers; von Post scale 6.

Oa - - 74 to 97 centimeters; black (10YR 2/1) sapric muck; 5 per cent unrubbed fibers; 2 per cent rubbed fibers; von Post scale 8; spongy consistence.

Oe - - 97 to 180 centimeters; dark brown (10YR 3/3) hemic sedge mucky peat; 40 per cent unrubbed fibers; 30 per cent rubbed fibers; von Post scale 4.

Cg - - 180 to 190 centimeters; dark grayish brown (10YR 4/2) very fine sand. 
Canaan Valley National Wildlife Refuge, Davis, Tucker County, West Virginia

4 June 2015

Profile 5.14, Sapric Haplohemist

Location: $39.12100,-79.38300$

Compiled by M. Schaney, J. Bernosky, H. Jewell, E. Davis, and T. Brangs

Oi - - 0 to 20 centimeters; dark brown (7.5YR 3/4) fibric sphagnum peat; 90 per cent unrubbed fibers; 80 per cent rubbed fibers; von Post scale 2; clear smooth boundary.

Bulk Density $(0-5 \mathrm{~cm})$ 0.16g/cm

Oa - - 20 to 32 centimeters; black (10YR 2/1) sapric muck; 5 per cent unrubbed fibers; 1 per cent rubbed fibers; von Post scale 7; field $\mathrm{pH}$ 4.3.

Oe - - 32 to 85 centimeters; dark brown (7.5YR 3/3) hemic mucky peat; 40 per cent unrubbed fibers; 25 per cent rubbed fibers; von Post scale 5; field $\mathrm{pH} 4.5$.

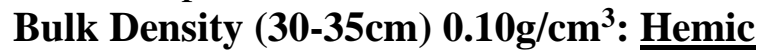

Bulk Density $(55-60 \mathrm{~cm})$ 0.06g/ $\mathrm{cm}^{3}$ : $\underline{\text { Fibric }}$

Oa - - 85 to 140 centimeters; black (10YR 2/1) sapric muck; 5 per cent unrubbed fibers; 1 per cent rubbed fibers; von Post scale 7; field $\mathrm{pH} 4.5$.

Bulk Density $(85-90 \mathrm{~cm})$ 0.15g/cm ${ }^{3}$ : $\underline{\text { Hemic }}$

Bulk Density (133-138cm) 0.33g/cm

C - - 140 to 180 centimeters; dark brown (10YR 3/3) silty clay with 30 per cent organic material; field $\mathrm{pH} 4.5$. 
Canaan Valley National Wildlife Refuge, Davis, Tucker County, West Virginia

4 June 2015

Profile 5.15, Sapric Haplohemist

Location: $39.12200,-79.37900$

Compiled by M. Schaney, J. Bernosky, H. Jewell, E. Davis, and T. Brangs

Coniferous needles throughout soil profile.

Oi - - 0 to 20 centimeters; dark brown (7.5YR 3/4) fibric sphagnum peat; 90 per cent unrubbed fibers; 80 per cent rubbed fibers; von Post scale 2; clear smooth boundary.

Oa - - 20 to 34 centimeters; black (10YR 2/1) sapric muck; 7 per cent unrubbed fibers; 1 per cent rubbed fibers; von Post scale 7.

Oe - - 34 to 70 centimeters; black (7.5YR 2.5/1) hemic mucky peat; 30 per cent unrubbed fibers; 20 per cent rubbed fibers; von Post scale 4. 29 to 32 centimeters macrofossil sample collected. Bulk Density $(35-40 \mathrm{~cm})$ 0.12g/cm³

Oa - - 70 to 110 centimeters; black (10YR 2/1) sapric muck; 5 per cent unrubbed fibers; 1 per cent rubbed fibers; von Post scale 7.

Bulk Density $(75-80 \mathrm{~cm})$ 0.15g/cm³

Oe - - 110 to 170 centimeters; dark brown (10YR 3/3) hemic mucky peat; 40 per cent unrubbed fibers; 20 per cent rubbed fibers; von Post scale 6.

Bulk Density $(130-135 \mathrm{~cm}) \mathbf{0 . 2 4 g} / \mathrm{cm}^{3}: \underline{\text { Sapric }}$ 
Canaan Valley National Wildlife Refuge, Davis, Tucker County, West Virginia

29 July 2015

Profile 5.16, Sapric Haplohemist

Location: $39.11989,-79.38625$

Compiled by M. Schaney, S. Morris, J. Baker, and A. Cimarolli

Oi - - 0 to 17 centimeters; dark brown (7.5YR 3/4) fibric sphagnum peat; 60 per cent unrubbed fibers; 50 per cent rubbed fibers; von Post scale 3/4; clear smooth boundary.

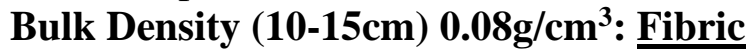

Fiber Content 56\%: Fibric

Pyrophosphate Color 2.5YR 8/2: Fibric

Lab pH: 2.64

Oe1 - - 17 to 50 centimeters; very dark grayish brown (10YR 3/2) hemic sedge mucky peat; 60 per cent unrubbed fibers; 25 per cent rubbed fibers; von Post scale 5; clear boundary.

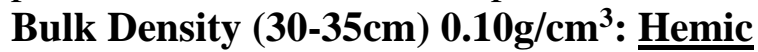

Fiber Content 44\%: $\underline{\text { Hemic }}$

Pyrophosphate Color 10YR 8/3, 10YR 8/4: Fibric/Hemic

Lab pH: 2.87

Organic matter: $99.57 \%$

Oe2 - - 50 to 72 centimeters; dark reddish brown (5YR 2.5/2) hemic mucky peat with cranberry roots and sphagnum macrofossils; 70 per cent unrubbed fibers; 30 per cent rubbed fibers; von Post scale 4.

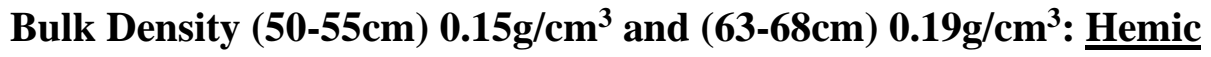

Fiber Content 22\%: $\underline{\text { Hemic }}$

Pyrophosphate Color 10YR 8/3, 10YR 8/2: Fibric

Lab pH: 2.65

Organic matter: $99.72 \%$

Oa1 - - 72 to 121 centimeters; black (10YR 2/1) sapric muck; 10 per cent unrubbed fibers; 2 per cent rubbed fibers; von Post scale 8 ; clear boundary. 80 to 85 centimeters pine needles, at 85 pinecone.

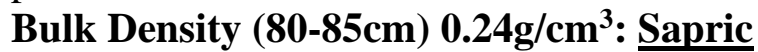

Fiber Content 8\%: $\underline{\text { Sapric }}$

Pyrophosphate Color 10YR 6/3, 10YR 5/4: Sapric

Lab pH: 2.96

Oa2 - - 121 to 171 centimeters; dark brown (10YR 3/3) sapric material; 35 per cent unrubbed fibers; 10 per cent rubbed fibers; von Post scale 7; texture similar to wet particle board.

Bulk Density $(140-145 \mathrm{~cm}) \mathbf{0 . 2 8 g} / \mathrm{cm}^{3}$ : Sapric

Fiber Content 8\%: $\underline{\text { Sapric }}$

Pyrophosphate Color 10YR 6/4, 10YR 3/4: $\underline{\text { Sapric }}$

Lab pH: 3.17

Organic matter: $\mathbf{9 0 . 0 7 \%}$ 
C - - 171 to 177 centimeters; dusky red (2.5YR 3/2) sandy loam. 
Canaan Valley National Wildlife Refuge, Davis, Tucker County, West Virginia

29 July 2015

Profile 5.17, Sapric Haplohemist

Location: $39.11749,-79.38399$

Compiled by M. Schaney, C. Schaney, S. Morris, J. Baker, and A. Cimarolli

Oi - - 0 to 16 centimeters; dark brown (7.5YR 3/4) fibric sphagnum peat; 90 per cent unrubbed fibers; 80 per cent rubbed fibers; von Post scale 2; clear smooth boundary.

Bulk Density $(5-10 \mathrm{~cm}) 0.11 \mathrm{~g} / \mathrm{cm}^{3}$ : $\underline{\text { Hemic }}$

Oa - - 16 to 30 centimeters; black (10YR 2/1) sapric muck; 10 per cent unrubbed fibers; 2 per cent rubbed fibers; von Post scale 8 ; abrupt boundary.

Fiber Content 12\%: Sapric

Pyrophosphate Color 10YR 6/4, 10YR 6/3: Sapric

Lab pH: 3.52

Organic matter: $92 \%$

18 -20cm Radiocarbon age $2070 \pm 30$ (median cal yr BP 2039)

Oe - - 30 to 94 centimeters; very dark brown (10YR 2/2) hemic sedge mucky peat; 60 per cent unrubbed fibers; 25 per cent rubbed fibers; von Post scale 5; diffuse boundary.

Bulk Density $(35-40 \mathrm{~cm}) 0.10 \mathrm{~g} / \mathrm{cm}^{3},(60-65 \mathrm{~cm}) 0.10 \mathrm{~g} / \mathrm{cm}^{3}$, and $(85-90 \mathrm{~cm}) 0.13 \mathrm{~g} / \mathrm{cm}^{3}$ : $\underline{\text { Hemic }}$ Fiber Content 24\%: $\underline{\text { Hemic }}$

Pyrophosphate Color 10YR 6/4, 10YR 7/3: Sapric/ Hemic

Lab pH: 2.88

Organic matter: $97 \%$

$70-72 \mathrm{~cm}$ Radiocarbon age $2705 \pm 30$ (median cal yr BP 2804)

$82-84 \mathrm{~cm}$ Radiocarbon age $2970 \pm 30$ (median cal yr BP 3135)

Oa1 - - 94 to 170 centimeters; black (10YR 2/1) sapric muck; 15 per cent unrubbed fibers; 5 per cent rubbed fibers; von Post scale 7; some sedge macrofossils at top of horizon and coniferous needles at 145 centimeters.

Bulk Density $(130-135 \mathrm{~cm}) 0.19 \mathrm{~g} / \mathrm{cm}^{3},(165-170 \mathrm{~cm}) 0.25 \mathrm{~g} / \mathrm{cm}^{3}$ : Sapric

Fiber Content 12\%: Sapric

Pyrophosphate Color 10YR 5/3, 10YR 4/4: $\underline{\text { Sapric }}$

Lab pH: 3.23

Organic matter: $90 \%$

$122-124 \mathrm{~cm}$ Radiocarbon age $3820 \pm 40$ (median cal yr BP 4217)

$130-132 \mathrm{~cm}$ Radiocarbon age $4580 \pm 30$ (median cal yr BP 5302)

$140-142 \mathrm{~cm}$ Radiocarbon age $4720 \pm 45$ (median cal yr BP 5460)

$161-163 \mathrm{~cm}$ Radiocarbon age $9160 \pm 45$ (median cal yr BP 10323)

Oa2 - - 170 to 205 centimeters; very dark brown (10YR 2/2) sapric muck; 20 per cent unrubbed fibers; 10 per cent rubbed fibers; von Post scale 7; texture similar to wet particle board; wood fragment at 185 to 189 centimeters; at 205 centimeters fine lens of (10YR 5/2) sand; seeds and a deciduous leaf imprint; abrupt boundary.

Bulk Density $(185-190 \mathrm{~cm}) 0.18 \mathrm{~g} / \mathrm{cm}^{3}$ : Sapric 
Fiber Content 12\%: $\underline{\text { Sapric }}$

Pyrophosphate Color 10YR 5/3, 10YR 5/4: $\underline{\text { Sapric }}$

Lab pH: 3.26

$173-175 \mathrm{~cm}$ Radiocarbon age $9930 \pm 30$ (median cal yr BP 11312)

$196-198 \mathrm{~cm}$ Radiocarbon age $11360 \pm 35$ (median cal yr BP 13203)

Oe - - 205 to 296 centimeters; dark brown (10YR 3/3) hemic sedge mucky peat; 40 per cent unrubbed fibers; 25 per cent rubbed fibers; von Post scale 6.

Bulk Density $(220-225 \mathrm{~cm}) 0.16 \mathrm{~g} / \mathrm{cm}^{3},(270-275 \mathrm{~cm}) 0.36 \mathrm{~g} / \mathrm{cm}^{3}$ : Hemic, Sapric

Fiber Content 36\%: Hemic

Pyrophosphate Color 10YR 7/3: Hemic

Lab pH: 3.71

Organic matter: $55 \%$

$225-227 \mathrm{~cm}$ Radiocarbon age $12310 \pm 35$ (median cal yr BP 14237)

$288-290 \mathrm{~cm}$ Radiocarbon age $12890 \pm 40$ (median cal yr BP 15382)

Cg - - 296 to 300 centimeters; gray (10YR 5/1) fine to medium sand.

Lab pH: 3.25 
Canaan Valley National Wildlife Refuge, Davis, Tucker County, West Virginia 17 May 2017

Profile 5.17, Sapric Haplohemist - REPEAT for pollen analysis

Location: $39.11708,-79.38451$

Compiled by M. Schaney, Z. Taylor, M. Albritton, and C. Anderson of Berry College

Oi - - 0 to 25 centimeters; dark brown (7.5YR 3/4) fibric sphagnum peat; 90 per cent unrubbed fibers; 80 per cent rubbed fibers; von Post scale 2; clear smooth boundary.

Oa - -25 to 47 centimeters; black (10YR 2/1) sapric muck; 20 per cent unrubbed fibers; 1 per cent rubbed fibers; von Post scale 8 ; abrupt boundary.

Oe1 - - 47 to 62 centimeters; very dark brown (10YR 2/2) hemic mucky peat; 40 per cent unrubbed fibers; 20 per cent rubbed fibers; von Post scale 6.

Oe2 - - 62 to 75 centimeters; black (10YR 2/1) hemic mucky peat; 30 per cent unrubbed fibers; 20 per cent rubbed fibers; von Post scale 5.

Oe3 - - 175 to 129 centimeters; very dark brown (7.5YR 2.5/2) hemic mucky peat; 50 per cent unrubbed fibers; 30 per cent rubbed fibers; von Post scale 5.

Oa - - 129 to 176 centimeters; black (10YR 2/1) sapric muck; 30 per cent unrubbed fibers; 17 per cent rubbed fibers; von Post scale 6.

C - - 176 to 190 centimeters; dark brown (7.5YR 3/2) silty clay.

Oe1 - - 190 to 283 centimeters; black (7.5YR 4/3) sapric muck; 60 per cent unrubbed fibers; 25 per cent rubbed fibers; von Post scale 6.

Oe2 - - 283 to 317 centimeters; dark brown (7.5YR 3/2) hemic mucky peat; 70 per cent unrubbed fibers; 30 per cent rubbed fibers; von Post scale 5.

Cg - - 317 + centimeters; gray (10YR 5/1) silt loam. 
Canaan Valley National Wildlife Refuge, Davis, Tucker County, West Virginia

29 July 2015

Profile 5.18, Entisol

Location: $39.12293,-79.39152$

Compiled by M. Schaney, S. Morris, J. Baker, and A. Cimarolli

Oi - - 0 to 7 centimeters; root mass.

Fiber Content 20\%: Hemic

Pyrophosphate Color 10YR 2/2: $\underline{\text { Sapric }}$

Lab pH: 2.86

A - - 7 to 13 centimeters; reddish black (10R 2.5/1) silt loam; moderate medium to coarse granular structure; clear boundary.

Fiber Content 28\%: $\underline{\text { Hemic }}$

Pyrophosphate Color 7.5YR 2.5/3: Sapric

Lab pH: 2.94

Organic matter: $67.06 \%$

Bw - - 13 to 26 centimeters; dark brown (10YR 3/3) silty clay loam with 20 per cent organic matter; coarse subangular blocky structure; wavy clear boundary.

Lab pH: 3.26

Cg - - 26 to 45 centimeters; brown (7.5YR 5/3) massive loamy sand.

Lab pH: 3.20 


\section{Appendix B \\ International Soil Radiocarbon Database QA/QC report}

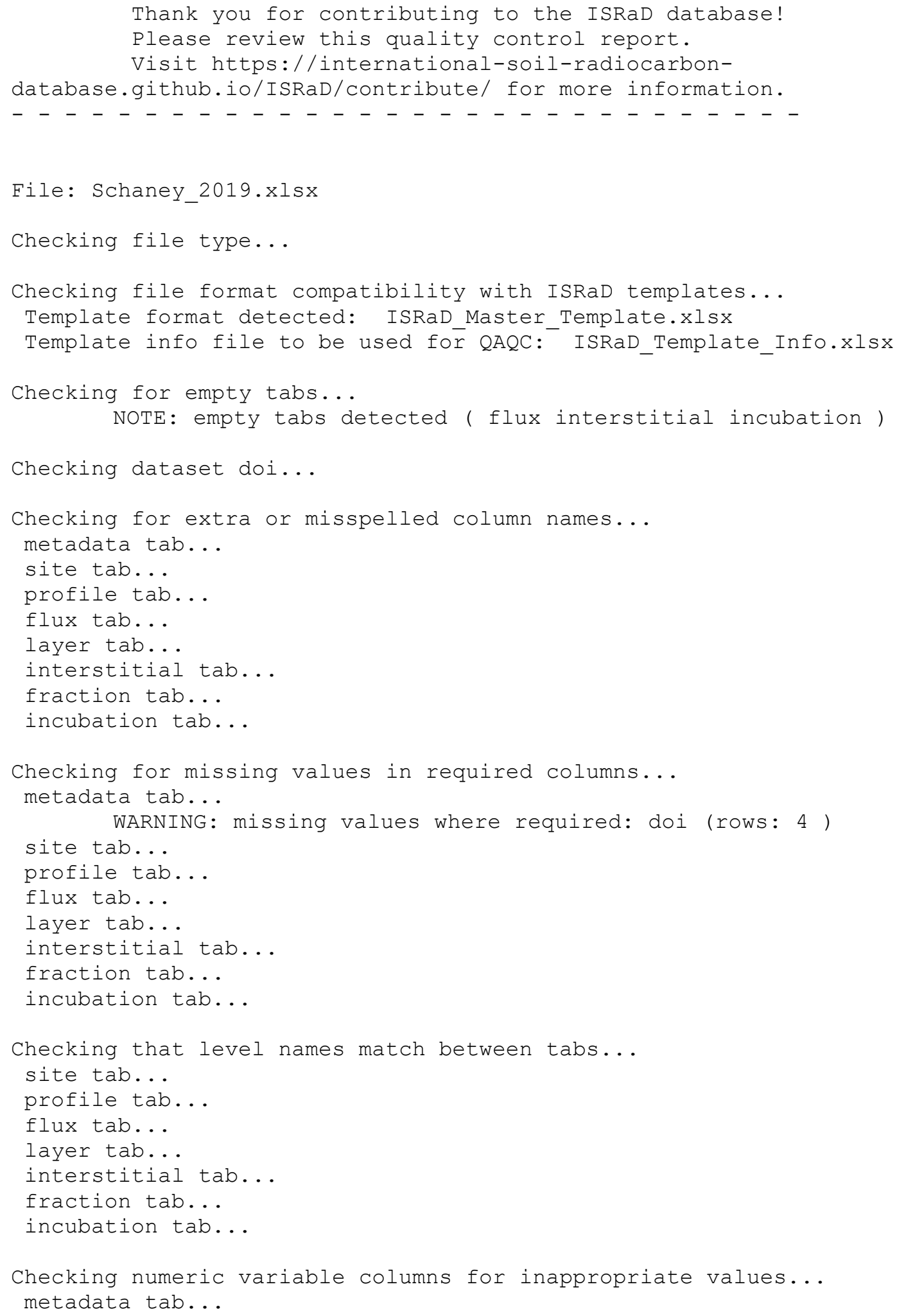




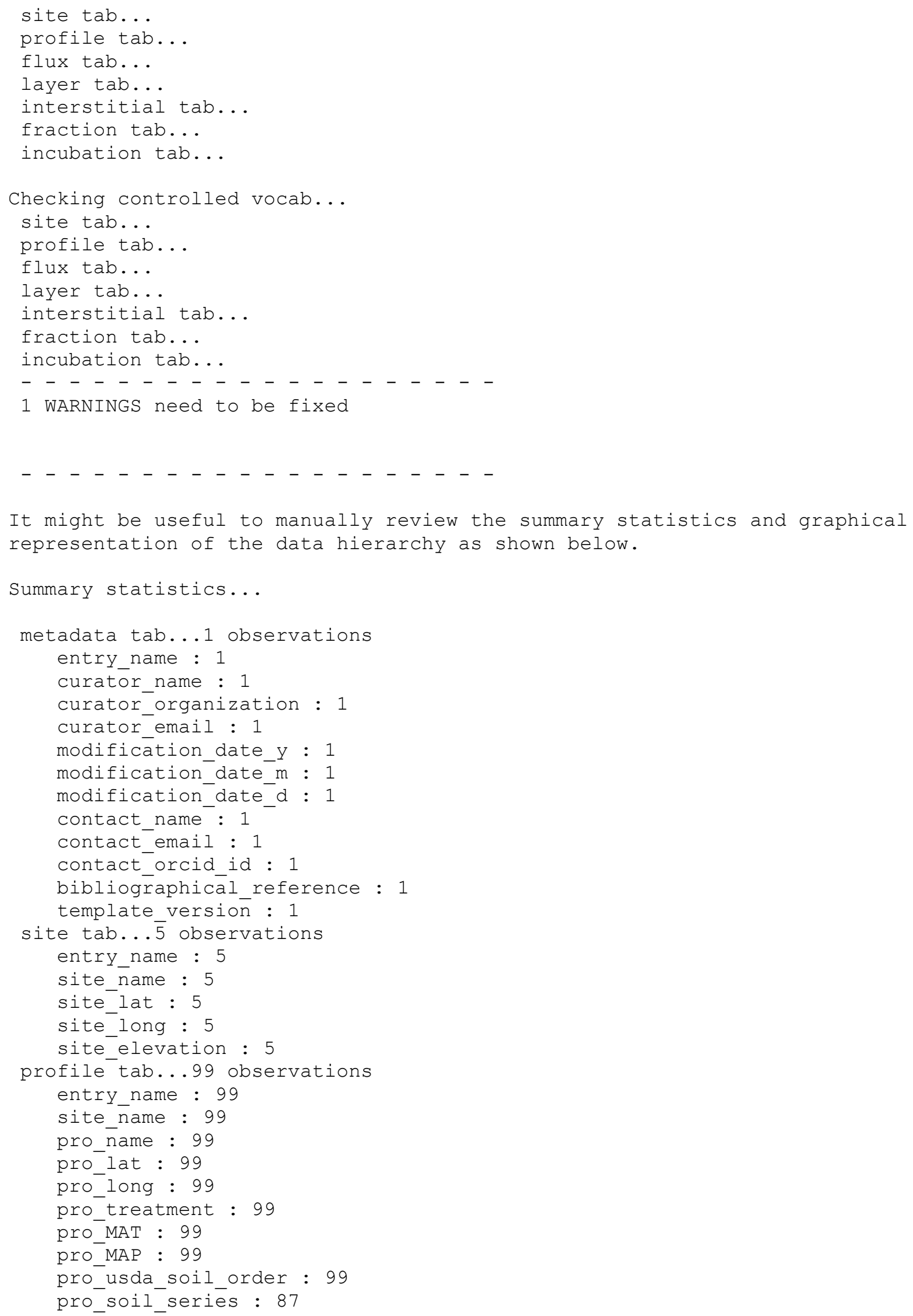




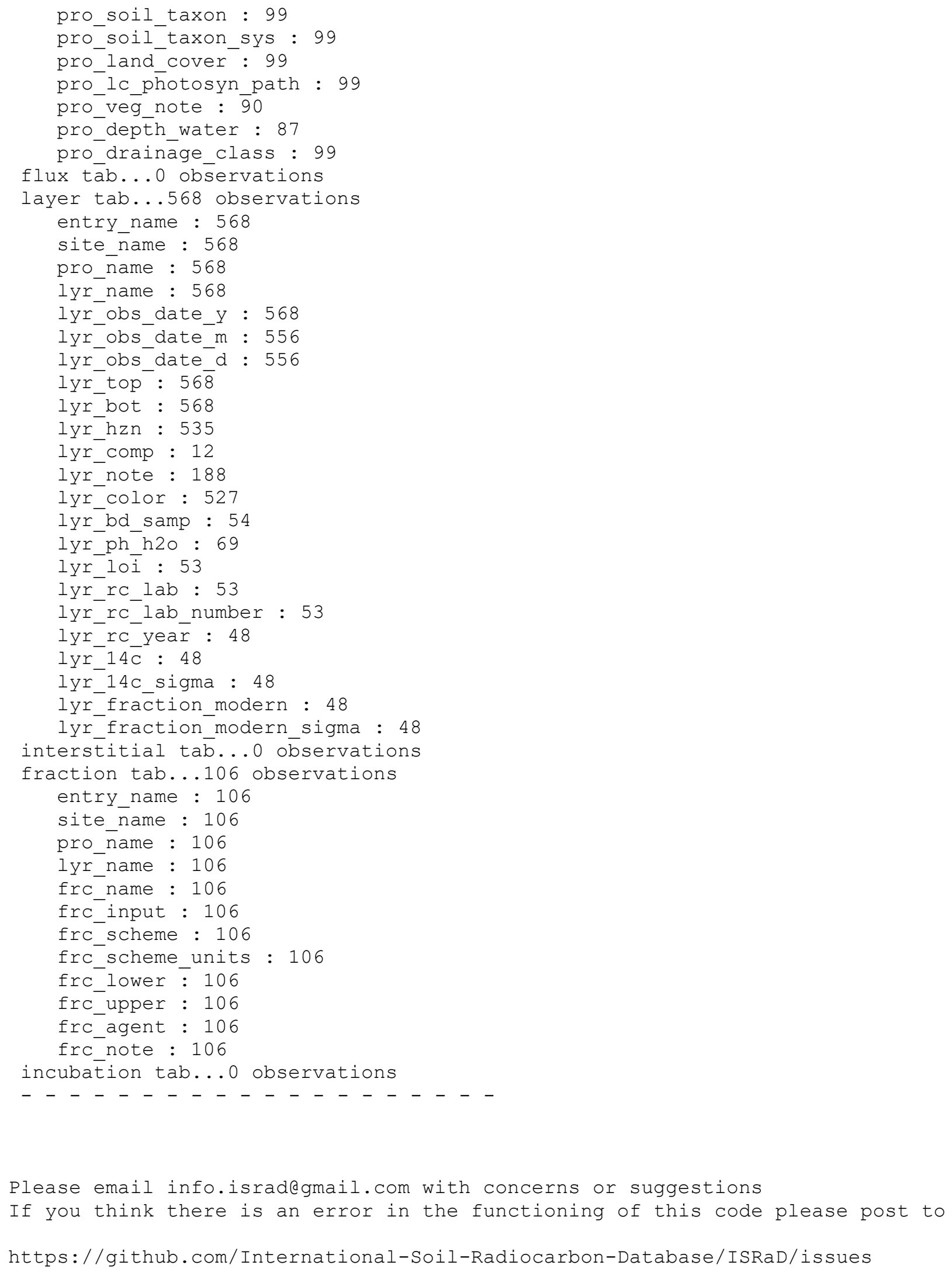

